Portland State University

PDXScholar

10-19-1978

\title{
A Tale of Two Cities: Public Housing and Municipal Revenue Policymaking in San Jose, Costa Rica and San Salvador, El Salvador
}

Paul Barrett MacDougall

Portland State University

Follow this and additional works at: https://pdxscholar.library.pdx.edu/open_access_etds

Let us know how access to this document benefits you.

\section{Recommended Citation}

MacDougall, Paul Barrett, "A Tale of Two Cities: Public Housing and Municipal Revenue Policymaking in San Jose, Costa Rica and San Salvador, El Salvador" (1978). Dissertations and Theses. Paper 862.

https://doi.org/10.15760/etd.862

This Dissertation is brought to you for free and open access. It has been accepted for inclusion in Dissertations and Theses by an authorized administrator of PDXScholar. Please contact us if we can make this document more accessible: pdxscholar@pdx.edu. 
A TALE OF TWO CITIES: PUBLIC HOUSING AND MUNICIPAL REVENUE POLICYMAKING IN SAN JOSE, COSTA RICA AND

SAN SALVADOR, EL SALVADOR

by

PAUL BARRETT MACDOUGALL

A dissertation submitted in partial fulfillment of the requirements for the degree of

DOCTOR OF PHILOSOPHY
in
URBAN STUDIES

Portland State University 
TO THE OFFICE OF GRADUATE STUDIES AND RESEARCH:

The members of the Committee approve the dissertation of

Paul Barrett MacDougal1 presented October 19, 1978.
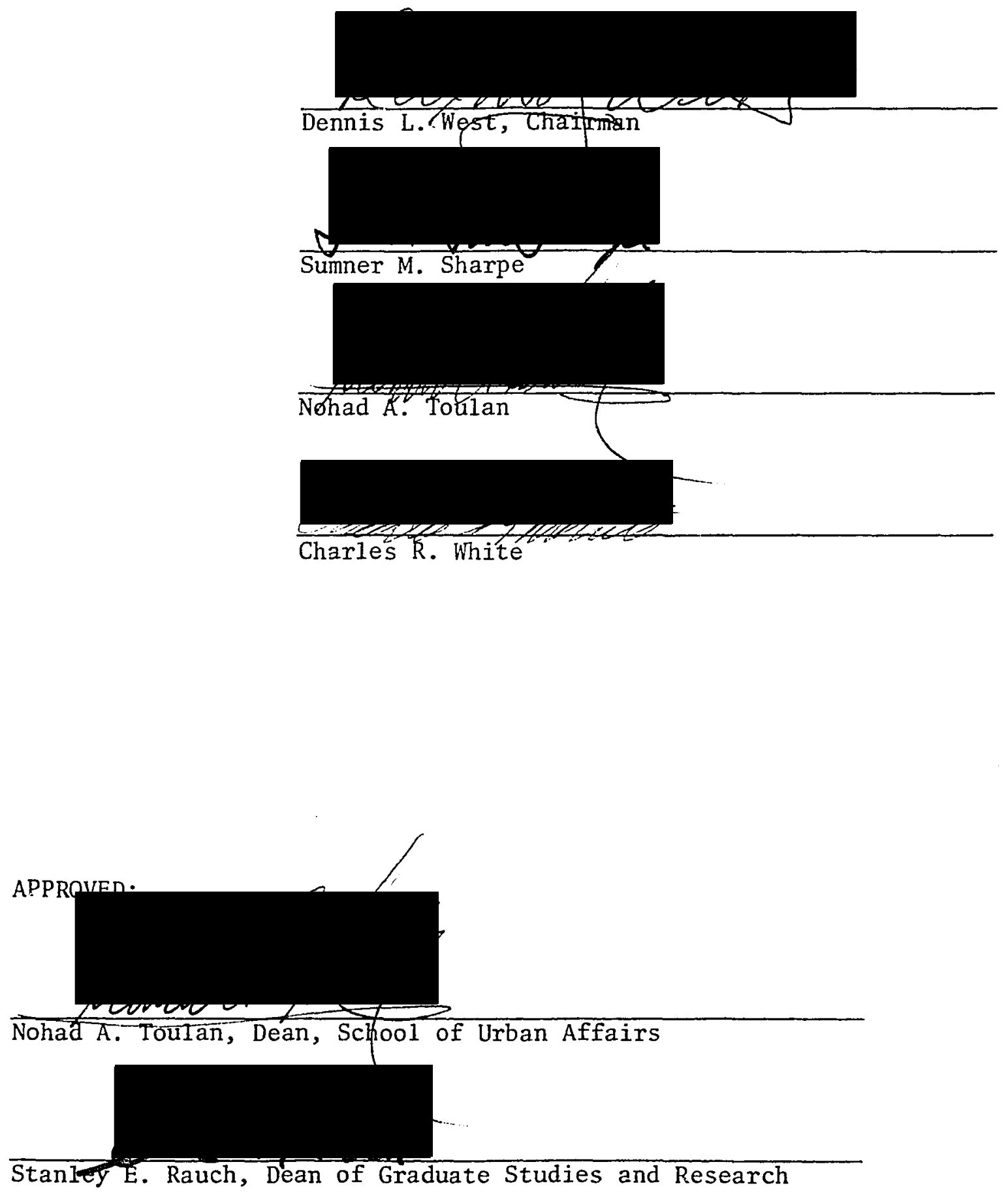
AN ABSTRACT OF THE DISSERTATION OF Paul Barrett MacDougall for the Doctor of Philosophy in Urban Studies presented October 19, 1978.

Title: A Tale of Two Cities: Public Housing and Municipal

Revenue Policymaking in San Jose, Costa Rica and San Salvador, El Salvador.

APPROVED BY MEMBERS OF THE DISSERTATION COMMITTEE:

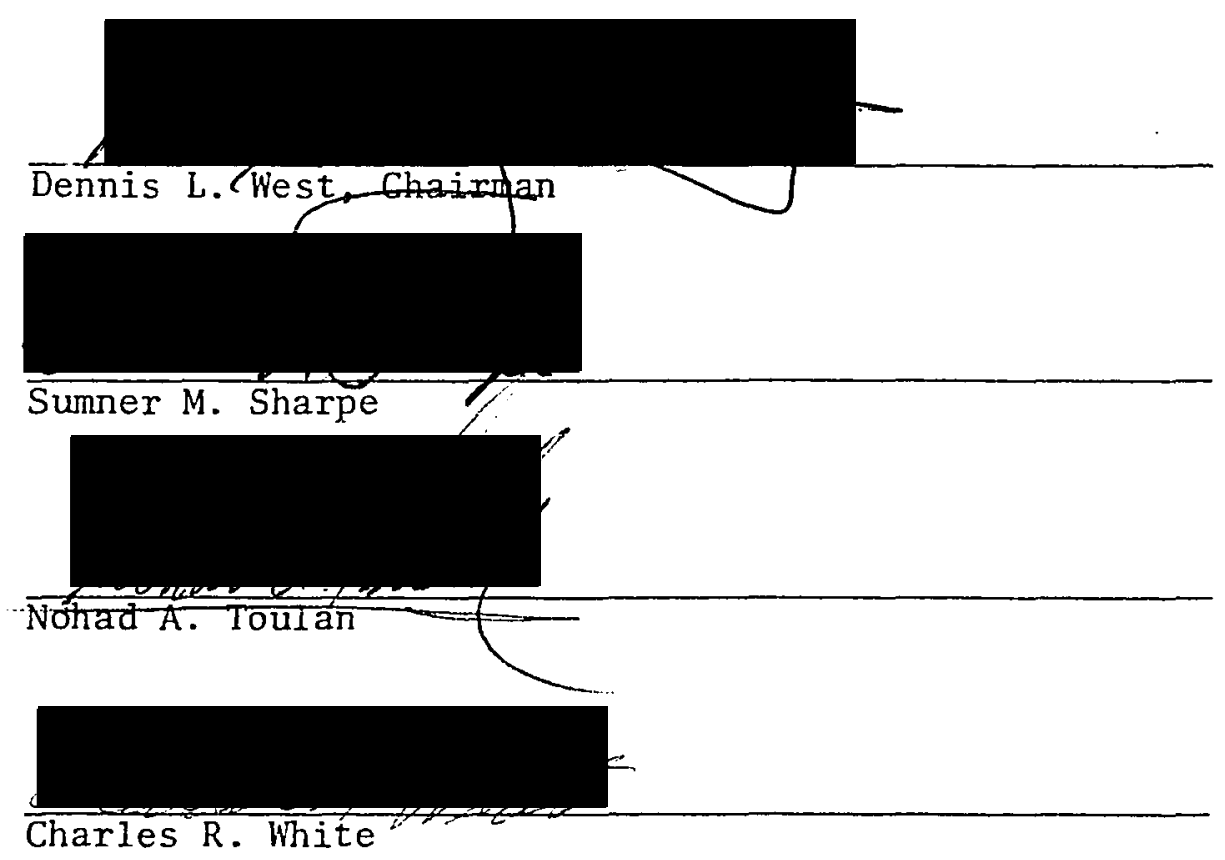

The scholarly tradition in urban policy analysis holds that a variety of economic, social and political background factors influence the nature and amount of output by the policymaking system. Here a number of these factors such as elections and parties, structure of the national economy and age and sex composition of the population are examined to determine their effect on public housing and local government revenue policy in two Central American urban centers. 
San Jose, Costa Rica and San Salvador, El Salvador were chosen for the study because they are in the same size range, both are capital (and primate) cities and both have been growing rapidly in recent years. Moreover, the cities exist in radically different sociopolitical milieux. With such characteristics as size and primacy held constant, it was felt that variations in policy output could be linked to and at least partially explained by the political, social and economic differences.

For a variety of systemic and historical reasons, urban public housing is provided in both countries by autonomous agencies of the national governments. Their operational policies and programs are compared.

Two major activities in the field of municipal revenue are traced through the policymaking process from their genesis: a successful effort to install parking meters in San Jose, and an unsuccessful attempt at overall tax reform in San Salvador.

In neither policy area, public housing nor municipal revenue, was the original hypothesis sustained. No important differences in policy output between San Jose and San Salvador could be identified. Consequently, there were no variations to be explained by the diversity in social, economic and political background factors.

Nonetheless, these factors are considered in detail, along with the nature of the policymaking process in the two cities. Finally, some suggestions are offered as to why San Jose and San Salvador exhibit these similarities in policy product in spite of their many social, political and economic dissimilarities. 


\section{ACKNOWLEDGMENTS}

I must, and wish to, acknowledge the assistance of several organizations and individuals without whose help this dissertation could not have been completed. A large debt is owed to the Canada Council whose financial support made the field work possible. Among the faculty members at Portland State University special thanks are due Dennis West and Charles R. White who not only midwifed the paper through its interminable birthing but many times hauled me back from the brink of despair. Without the help of Margaret Lynch, my crude scribblings would never have become a readable draft.

A student carrying out research in foreign lands and with an imperfect command of the local idiom owes more gratitude to more people than does one researching in familiar territory. Would a Central American student, speaking badly broken English who descended on government and business leaders; constantly requested interviews; demanded details of administrative structure, fiscal organization and the policymaking process; sought access to, and help in sorting through, long-buried records; and generally disrupted office procedure for weeks on end, be as well received in Portland as I was in San José and San Salvador: Unforiunately, I think not. If this list of people whose help has proved invaluable is, then, longer than usual, it is still shorter than it might be.

In San José, Ernesto and Roberta Macaya opened the first doors for me and, months later, were still opening doors for me. Dr. Samuel 
Stone at the University of Costa Rica suggested readings I otherwise would not have found. Licenciado Eduardo Longan at the Central Bank of Costa Rica, Georgina Salazar at Statistics and Census, and Olga Marta Mesen at the Comptroller General sought out the precise data I was after. At IFAM (Institute for Strengthening and Assisting Municipalities), two people went far out of their ways to help me. Lic. Edgar Muñoz not only provided me with a desk, the run of the office and the opportunity to talk to his entire staff, he also gave me unprecedented freedom to take materials home and shared his own research with me. Lupita Rodríguez Mendez led me instantly to any naterial I was seeking, and knew of English versions of documents I had located only in Spanish.

Deputy Oscar Saborio Alvarado took time not only from his business but also from the harried last days of the Legislative Session to provide me with insights into the workings of the Assembly--insights I could have obtained nowhere else. Architect Jorge Crespo patiently expiained the functioning and policies of INVU (Nacional Institute of Housing and Urbanization). Lic. Mauricio Alvarado Cader and Ofelia Achong also assisted me greatly.

I have no debt greater than that owed Elisa Pérez Ruiz, Keeper of the San Jose Municipal Archives and her staff: Carmen Cabezas Soto, Victor Gerardo Gaitán and Rafael Angel Gutiérrez Monge. She not only found all the information I asked for, but once she knew the nature of my project, she unearthed information whose existence never would have occurred to me. Moreover she cut red tape to allow me to take out and photocopy the only existing copy of some archival material 
and she arranged introductions to members of the Legislative Assembly. Finally, she interceded with the airline so I would not have to pay excess weight charges on the mounds of paper with which I left Costa Rica. Thank you, Doña Elisa.

My debts in San Salvador are as many and as varied. Dr. Alfred Cuzan, doing his own research, graciousiy shared his thoughts and his contacts. At the José Simeon Cañas University of Central America, Dr. Julio Sifontes, Engineer Hector Dada, and especially Architect José Manuel Murillo explained in great detail the actual, as opposed to the theoretical, relations among the various agencies involved in planning, housing and urban service delivery. Father Antonio Fernandez Ibañez, Executive Director of FUNDASAL (Salvadorean Foundation for Development and Minimum Housing), not only clarified the whole area of public housing but explained the political and community organizing that accompanied it. Dr. Victor Manuel Cuéllar Ortiz, Manager of the Salvadorean Association of Industrialists provided me with otherwise unobtainable insights and viewpoints of the business community.

Government officials were no less helpful. Lic. Mario Arnoldo Sánchez at CONAPLAN (National Council for Planning and Economic Development), Architect Oscar Arrivillaga at IVU (Institute of Housing and Urbanization) and Engineer Eduardo Varaona of the Directorate of Urbanism and Architecture gave freely of their time and expertise as did Dr. José Luis Ayala García, Vice-Minister of the Interior. At the local level, Don Daniel Escobar, Municipal Secretary of San Salvador, patiently explained the administrative organization and procedures. A special debt is owed Dr. Fidel Chávez Mena. He explained how 
his seminal work "Organización Municipal" was developed, answered my myriad questions on policymaking in San Salvador and the political re1ations between city and nation, and used his position as City Councillor to open some valuable doors for me.

And speaking of myriad questions, no one endured more of them nor responded with better grace than Marie Brown in the Office of Graduate Studies and Research who is responsible for any consistency of form this paper may possess.

Finally, there are many unnamed people whose help I acknowledge here. Some of these are unnamed through my negligence but the majoriťy, for a variety of very good reasons, requested anonymity. I accede to this request with appreciation for their assistance.

With so many people having aided me in the preparation of this dissertation, there is abundant opportuity to spread the responsibility for any shortcomings. Tradition, however, requires the writer to assume such responsibility. I do so willingly:

And if my poor talents, my little experience of the present and insufficient study of the past, should make the result of my labors defective and of little utility, I shall at least have shown the way to others, who will carry out my views with greater ability, eloquence and judgment, so that if $I$ do not merit praise, I ought at least not to incur censure. (Machiavelli, Introduction to the Discourses.) 
TABLE OF CONTENTS

PAGE

ACKNOWLEDGMENTS ....................... . . . . .

LIST OF TABLES . . . . . . . . . . . . . . . . $x$

LIST OF FIGURES . . . . . . . . . . . . . . . . . . xii

\section{CHAPTER}

I INTRODUCTION . . . . . . . . . . . . . . 1

I I REVIEW OF THE LITERATURE . . . . . . . . . . 16

III POLICY ANALYSIS . . . . . . . . . . . . . 47

Nature of the Policy Process . . . . . . 47

A Model of the Policy Process ........ 57

Use of the Policy Approach . . . . . . . . 59

The Policy Analysis Tradition . . . . . . 61

The Comparative Approach . . . . . . . . 71

IV POLICY AREAS . . . . . . . . . . . . . . 77

Municipal Revenue Raising ........ 78

Public Housing . . . . . . . . . . 92

V BACKGROUND FACTORS . . . . . . . . . . . 107

Political Factors .. . . . . . . . 107

Structure of City Government

Relations between Municipal and National Governments

Role of Parties and Elections

Importance of Non-governmental Groups

Policy Preferences of Leaders of City

Government 
Economic Factors . . . . . . . . . . . .

Economic Structure

Public-Private Mix

Distributional Aspects

National Government Revenue Patterns

National Govermment Expenditure Patterns

Social Factors . . . . . . . . . . . .

Population and Trends

Age and Sex Structure $-\quad \longrightarrow$

Internal Migration

Educational Achievement

Group Structure

The General Plan . . . . . . . . . 200

VI THE POLICY PROCESS . . . . . . . . . . . . 207

Housing Policy ............ . . 208

General Municipal Revenue Policy . . . . . 214

San Salvador--Tax Reform and How It Failed The Parking Meter Comes to San José

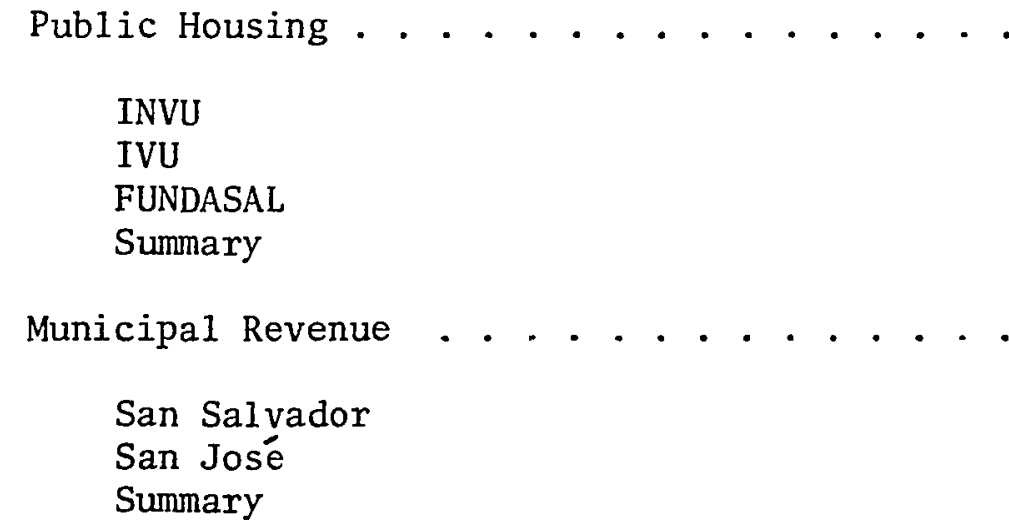

VIII CONCLUSION . . . . . . . . . . . . . 305

BIBLIOGRAPHY . . . . . . . . . . . . . . . . . 330

APPENDICES . . . . . . . . . . . . . . . . . 349

Appendix A . . . . . . . . . . . . . . . 349 
PAGE

Appendix B . . . . . . . . . . . . . . . . 352

Appendix C . . . . . . . . . . . . . . . . 356

Appendix D . . . . . . . . . . . . . . . 359

Appendix E . . . . . . . . . . . . . . . 364

Appendix F . . . . . . . . . . . . . . 367 
LIST OF TABLES

TABLE

PAGE

I Seats Held in San José and Costa Rica, By Party . . .

II Costa Rica and EI Salvador: Structure of Gross

Domestic Product at Current Prices . . . . . 156

II Costa Rica and E1 Salvador: Percentage Composition of Gross Domestic Product By Individual Sector . 158

IV Costa Rica and El Salvador: Structure of Gross Domestic Product at Fixed (1962) Prices . . . . 159

V Costa Rica and E1 Salvador: Percentage Change in Gross Domestic Product, 1967-1972 . . . . . 160

VI Average Labor Force By Industrial Sector, and Unemployment (1972) . . . . . . . . . 161

VII Percentage Composition of Gross Domestic Product By Sector (Public-Private Mix) ......... 163

VIII Per Capita Gross Domestic Product and Changes, 19671972 . . . . . . . . . . . 164

IX Per Capita Income, 1960 and 1970 . . . . . . . . 164

X Income Distribution, By Income Class, 1970 . . . . 165

XI Costa Rica--National Government Income, 1967 and

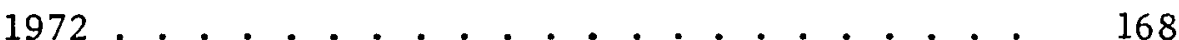

XII El Salvador--National Government Income, 1967 and 1972 . . . . . . . . . . . . . 169 
TABLE

XIII Costa Rica--National Government Expenditures, 1967 and 1972 . . . . . . . . . . . . . 180

XIV E1 Salvador--Nationa1 Government Expenditures, 1967 and 1972 . . . . . . . . . . . . . . . . 181

XV Costa Rica and E1 Salvador: Population and Decennial Changes . . . . . . . . . . 184

XVI Age and Sex Distribution of Population . . . . . . 186

XVII Indices of Femininity, By Age . . . . . . . . 187

XVIII Net Inmigration to San José and San Salvador . . . . 190 XIX Costa Rica and El Salvador: Educational

Achievements . . . . . . . . . . . . 194

XX Excerpt from San Salvador Tariff Structure . . . . 222

XXI Proceeds of Parking Meter Operations, 1971-1973 . . 247

XXII Estimated Parking Meter Revenue, 1974 ....... 247

XXIII Housing Assistance Provided By INVU, 1967 to 1972 • • 256

XXIV Typical Payment Schedule, INVU Savings and Loan

Program . . . . . . . . . . . . . 260

XXV Housing Assistance Provided By IVU, 1967 to 1972 . 267

XXVI Maximum Allowable Cost for IVU Housing . . . . . 268

XXVII Comparison of Housing Needs and Public Supply, Costa

Rica and E1 Salvador, 1965 and 1970 . . . . 283

XXVIII Municipality of San Salvador, Cash on Hand and Projected Revenue, 1973 .......... 287

XXIX Proposed San Salvador Municipal Expenditures, $1973 \quad$ • 288

XXX Municipality of San José, Projected Revenue, 1974 • . 291 
LIST OF FIGURES

FIGURE

PAGE

1. Map of E1 Salvador . . . . . . . . . . . . . . 3

2. Map of Costa Rica . . . . . . . . . . . . . 5

3. Model of the Policymaking Process . . . . . . . . 58

4. Dawson-Robinson Policy Process Mode1 . . . . . . 62

5. Dye Policy Process Model ............. 63

6. Salisbury Policy Process Model . . . . . . . . 65

7. Rakoff-Schaefer Policy Process Mode1 . . . . . . . 67

8. Evolutionary Model of the Municipal Tax System . . . . 90

9. Analysis of Alternative Tax Practices . . . . . . . 91

10. San Salvador--Administrative Structure . . . . . . 125

11. San José--Administrative Structure . . . . . . . 127

12. Agencies Providing Municipal Services in San José and San Salvador . . . . . . . . . . . . . . 135

13. Selected Financial Data for INVU, 31 December 1972 . . 262

14. Selected Financial Data for IVU, 30 June 1973 . . . . 269

15. Characteristics of Public Housing Agencies . . . . . 281

16. Sample Lorenz Curves . . . . . . . . . . . . . 352 
CHAPTER I

INTRODUCTION

In a recent article Charles 0 . Jones pointed out that a review of the literature on state and local policy analysis indicates "that lots of things are related to lots of things, other things being 1 equal." The 'things' referred to are generally, on the one hand, economic, political, and sociar background factors, and on the other, some policy outputs. It is the intent of this study to examine and compare the policy consequences of these factors in two Central American urban centers, San José, Costa Rica and San Salvador, El Salvador. The appropriate scholarly literature on these locations is reviewed in Chapter II.

The policymaking process, with its attendant struiture, both serves as nexus in the transformation of these background factors into policy outputs and is itself a variable. Models for the analysis of this process abound. Our model of choice is presented in Chapter III, along with its genesis in our particular needs and the policy analysis tradition. Here, too, will be found the rationale for our taking a comparative approach to the analysis of urban public policy.

To try and examine the entire range of policy possibilities for these two municipalities would be to enmesh ourselves inextricably in a thicket of minutiae; the forest of significant relationships would be hidden by the trees of trivia. Consequently, we limit our study to 
two substantive areas, revenue raising and the provision of public housing. Reasons for our choice of these fields and some of the general principles thereof will be presented in Chapter IV.

Various political, economic, and social factors for the two polities will be compared in Chapter V. Chapter VI will consider the policy process itself, both generally in San José and San Salvador and with particular examples from the revenue and housing ficids. In Chapter VII the results of this process will be examined, and Chapter VIII will present what we have concluded from all this. This zemainder of this first chapter is devoted to a brief introduction to San José and San Salvador and their national milieux, and to a formal siatement of our basic hypotheses.

E1 Salvador is the smallest country on the American mainland. Occupying 8,259 square miles, it is about the size of Massachusetts. (Were the country square, it would be 91 miles on a side.j It lies between $13^{\circ} 08^{\prime}$ and $14^{\circ} 24^{\prime}$ North latitude and $87^{\circ} 39^{\prime}$ and $90^{\circ} 08^{\prime}$ West longitude. Bounded on the west by Guatemala, the south by the Pacific Ocean, the north and northeast by Honduras and the southeast by the Gulf of Fonseca, it is the only country north of Ecuador lacking an Atlantic (or Caribbean) coast. (See map, Figure 1, p. 3.)

E1 Salvador is not only the smallest country in Central America, it is also the most densely populated, with a population of $3,549,260$ counted in the 1971 census, estimated at 4,180,000 in 1976 and pro3 jected at $5,000,000$ by 1981 . In 1971 , some 560,500 of these people 4

lived in San Salvador. Not only is the country densely populated, its rate of natural increase, 3.9 per cent annually, is the highest 


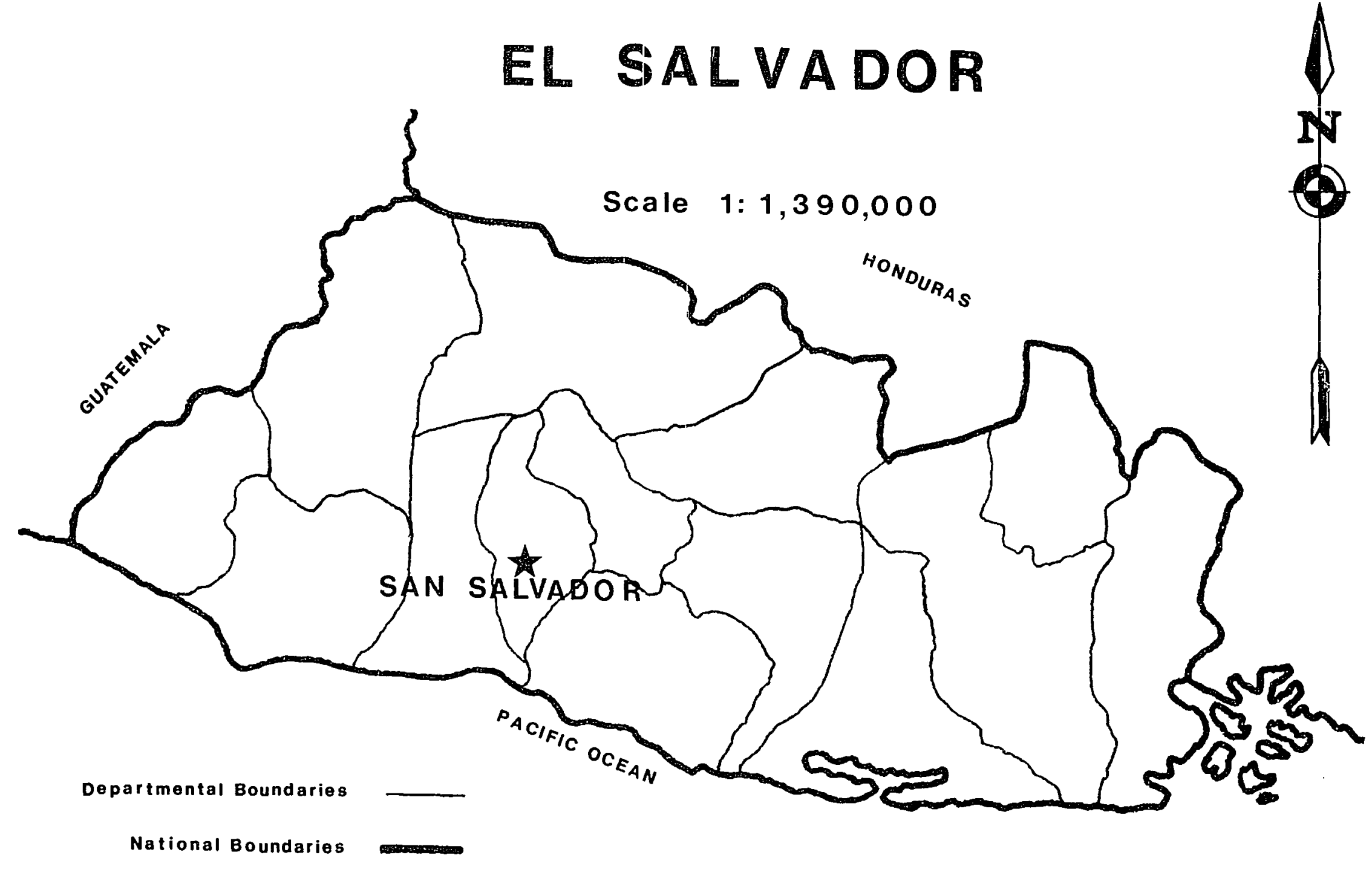

Figure 1. Map of E1 Salvador. 
in the world.

Gonzalo de Alvarado founded the city of San Salvador in the Zolcoatitan Valley in 1525. Cuzcateclos Indians, annoyed by this Spanish effrontery, burned it in 1526. Rebuilt, the city served as capital of colony, federation and republic. It was destroyed again, totally, by an earthquake in 1854. Consequently, few traces of the colonial era remain. During the late 19 th and the 20 th centuries San Salvador has been reconstructed.

It is simplistic but not inaccurate to construct a stereotypical model of El Salvador as it exists today. It will contain a population about one-third literate and overwhelmingly mestizo but with a wealthy cap of whites. It will include a system of concentrated land ownership with agricultural emphases on two major export crops, cotton and coffee. Moreover it will incorporate a recent political history of minimum government involvement in the society, a chronicle of government as provider of control and regulation, not of services.

The policymaking environment will be dominated by a patronageridden bureaucracy, national single-party rule, and the dominance of the military in this single party. Political power will be centralized, the national government barely acknowledging the existence of local government. In fact, we find the govermment of the capital city in complete, bitter, partisan, ideological and pragmatic conflict with the national government. This animus has existed openly for at least ten years; it shows no signs of abating.

Costa Rica at 19,575 square miles is the second smallest nation in Central America, about the same size as West Virginia. (If square, 
it would be about 140 miles on a side.) Lying between $08^{\circ} 02^{\prime}$ and $11^{\circ} 13^{\prime}$ North latitude and $82^{\circ} 34^{\prime}$ and $85^{\circ} 58^{\prime}$ West longitude, it is bounded on the north by Nicaragua, the northeast by the Caribbean Sea, the east by Panamá and the west and southwest by the Pacific Ocean. (See map, Figure 2, p. 6.)

Not only is Costa Rica larger than El Salvador, it is less densely populated. The 1973 census found $1,840,730$ inhabitants of whom some 419,000 lived in urban San José. National population is projected to reach $3,682,000$ in the year 2000 . In the early 1960s Costa Rica had an annual rate of population increase of 3.8 per cent; in recent years the figure has dropped below 2.0 per cent.

Costa Rica, despite its name meaning rich coast, was a great disappointment to the Spanish conquistadores. No mineral wealth was to be found and the Indians proved truculent and unsuited to indentured service in hacienda operations. San José is a relatively young city; it was not founded until 1737. Consequently it is the least Spanish in appearance of any Central American capital. Unlike San Salvador, San José was not a colonial capital. Cartago was the original capital of both colony and nation, losing its status to San José in 1823 following a factional dispute.

As we did for El Salvador, we can construct a simple but representative model of Costa Rica today. In it we will include a history of gradual expansion of public services such as education, insurance, social security and government guaranteed mortgages. To this we will add a highly literate (c. $80 \%$ ) and, alone in Central America, a predominantly white population. (Little race mixing has occurred in Costa 


\section{COSTA RICA}

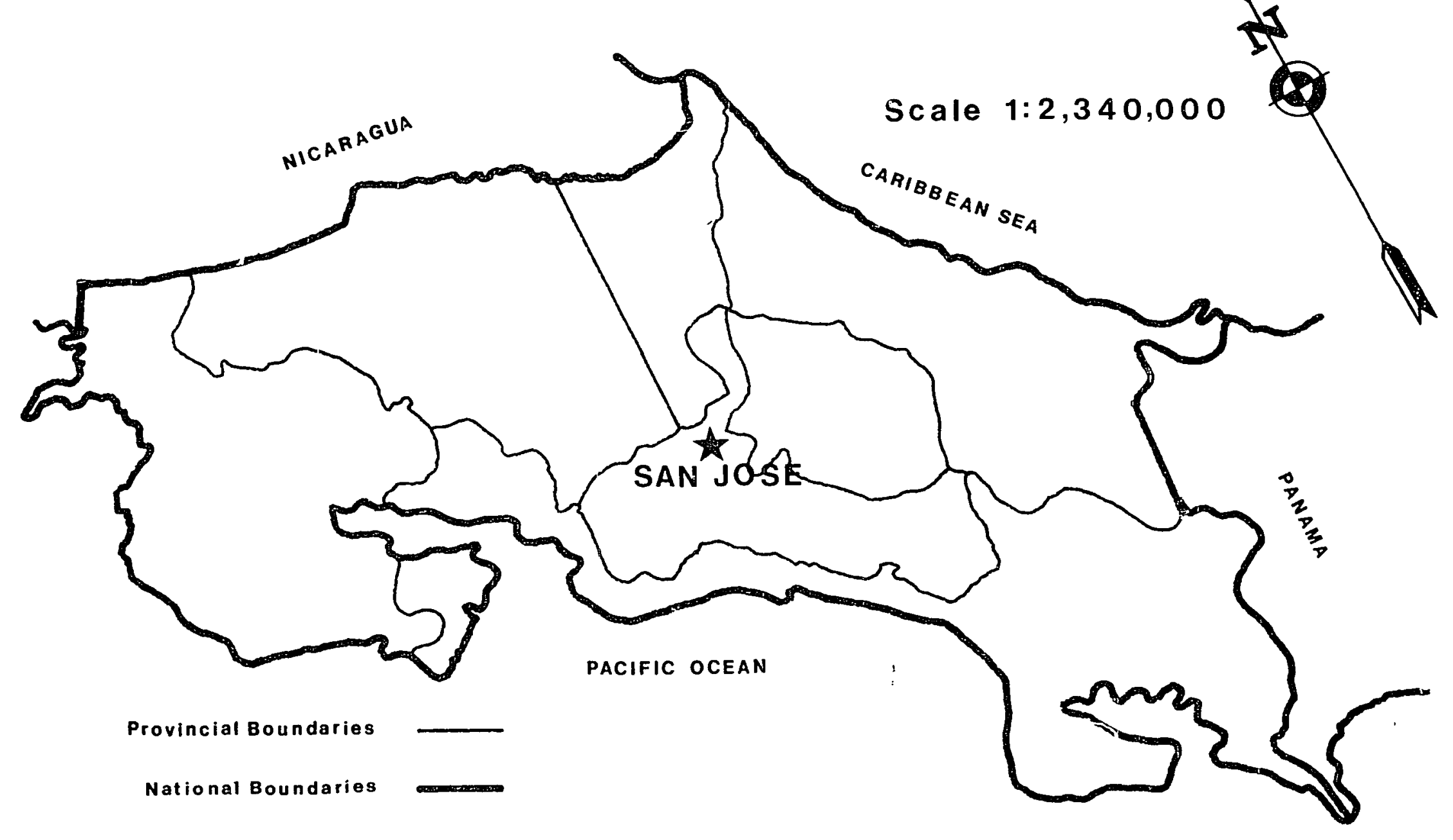

Figure 2. Map of Costa Rica. 
Rica. Until recently the black population was restricted to the Caribbean littoral; the Indians are for the most part on isolated reservations, effectively outside the national life.) The ownership of land we expect to be fairly evenly distributed by Latin American standards, with the economy based on foreign sales of coffee and bananas.

Developing the model further, we will combine a strong tradition of administrative decentralization, a stable pattern of electoral competition, a disbanded military and the presence of many active and potent professional and economic associations. To complete the model, we incorporate a central government that, at least rhetorically, embraces local government as a partner in national development. The result, then, is a model of polity and a policymaking process that is "very open, stable, competitive and often indecisive."

We have, therefore, two stereotypical models representing the traditional extremes in Latin American policymaking systems. The comparative importance lies in determining whether and to what extent quality and quantity of policy responses are determined, or at least influenced, by these apparently antipodal sociopolitical cultures.

The two cities chosen, San José and San Salvador, were selected because they are in the same size range and because both are not only capitals but also primate cities. As a result they face many similar problems and prospects. At the same time, the two cities differ significantly with respect to political milieux and population growth. An additional factor in their choice is proximity which enabled both localities to be visited more than once in the course of a single field investigation. 
It was anticipated that the results of this comparative study would enable us to indicate the differing effects of political, social and economic factors on policymaking in the two cities. Our assumption was that the characteristics of each city would affect the range of policy alternatives considered, the nature of the policy process, and finally the policies selected.

The following two areas were chosen as the foci of the research; revenue, i.e., policies designed to raise revenue, from whatever source, to support other public policies, and the public provision of housing. These problem areas were chosen because historically they have been prominent political issues in Latin American urban centers. With rapid urban growth, increased demands have been placed on all levels of government to supply urban services of all kinds, including housing. These demands have resulted in the necessity of increasing revenue in order to finance this expansion. Within each of these issue areas, municipal governments have a constrained set of alternatives open to them.

One question that has been raised and deserves an answer is, "Why, in nations as small as Costa Rica and El Salvador, do you not ignore the cities and concentrate on the countries?" Although the Central American municipality is weak, constitutionally and politically, when compared to its counterpart in Anglo America or Western Europe, it is far from unimportant. Many of the services of immediate concern to the inhabitants are provided by or under the control of the municipality, alone or in concert with other agencies.

Much of the scant attention paid Central America by North Aner- 
icans, including scholars, has been directed to the series of unstable national governments that have characterized some Central American nations. It is usual to attribute at least part of this instability to the 'revolution of rising expectarions.' Within these nations, these rising expectations have generally involved not national policies of global concern but matters of local service delivery, i.e., rising bus fares, deteriorating streets, inadequate fire protection.

Urban politics thus lie at the heart of national politics. Latin American political systems, to whatever extent control and administration are centralized, are composed of local and regional systems. At the head of this is the political network of the capital city, a political entity in its own right. A capital city, particularly when it is, as San Salvador and San José are, also a primate city, is expected to be growing faster than the country as a whole and to possess a disproportionate share of the nation's wealth, education, technical skill and culture. Much of the nation's public revenue is also generated here although, as will be demonstrated later, not as high a percentage as would be the case if taxation systems were reformed and modernized. The city will also contain most of the country's drunks, prostitutes, and political and administrative talent. While the majority of the political elite of the metropolis will be dealing with issues of national concern and actually working in national government institutions, it will be doing so within the political milieux of the capital city. In short, a great deal of what is characterized as national politics is based in and concerned with interests and problems of the capital city. Some of the research considerations that led to the choice of 
Central American cities, and these two cities in particular, have been indicated above. Three others might be mentioned here. One is that neither San José nor San Salvador is a federal district as are, for example, Managua and Tegucigalpa. Thus both are involved in local politics and are not simply wards of the central government. Another is the fact that in Costa Rica the same broad range of political parties is found in both the council of the capital city and the national legislature whereas in El Salvador the party in opposition nationally controls the govemment of the capital city. Moreover, there is the writer's personal idiosyncratic choice, based in part on earlier research in Central America.

As a final research consideration, Gary Wynia has suggested that there exists a 'competitive' political culture in Costa Rica and a 'bargaining' culture in El Salvador. If these are reflected in municipal government, and we have shown below the extent to which they are, we might expect to find, in the terminology of Robert Agger and associates a 'consensual elite' situation in San Salvador and a 'competitive mass' in San José. Again, we see below whether this hypothesis (guess) holds.

There exists a general assumption, almost a consensus, in the policy analysis literature that a wide range of economic, social and political considerations constitute independent variables with policy decisions as dependent variables. The policymaking process itself is assigned roles of varying importance according to the view of the individual analyst.

In this study we examine a number of these background factors, 
both for San José and San Salvador and for their respective national settings. Under the general label of political we include such factors as the constitutional provisions relating to the municipalities, their legislative and administrative structures, the relationships between municipalities and national governments, the role of parties and elections in determining control of positions in the city government, the policy preferences of local government leaders and the importance of non-governmental groups in the policy process. Economic factors ineconomic structure of both cities and countries, labor force composition and employment rates, the public-private mix, income and its distribution, growtin rates and the patterns of revenues and expenditures for national governments. Among social factors to be studied are population, its age and sex structure and rate of increase, internal migration, educational levels and group structure. The appropriate data on these background factors are assembled and analyzed below in Chapters $\mathrm{V}$ and VII.

This inventory of background factors constitutes the traditonal list that analysts of state and local public policymaking in the AngloAmerican setting have suggested are important. For this study we have added one more, the existence of a comprehensive plan for metropolitan development in San Salvador and the absence of any such plan for San José.

With all of this in mind, it becomes possible to briefly define the current study in terms of two sets of formal hypotheses:

1 Ho: There exist no significant differences in policymaking and policy outcomes between San Salvador and San José. 
Ha: There do exist significant differences.

2 Ho: Differences in (1) are not related to the social, political and economic differences between San José and San Salvador.

Ha: Differences in (1) are related to such social, political and economic differences.

The main thrust of this study, then, is testing these hypotheses in the policy areas of urban revenue raising and the public provision of housing.

However, the results of the study were not as anticipated. The alternative hypothesis in (1) was expected to hold. It did not hold. But even with the null hypothesis in (1) supported, our analysis in (2) need not be unnecessary or redundant. We found there to be no significant policy differences between San José and San Salvador, and must ask, Why is this so? Are the background factors too similar, was our selection of them incorrect, did we in fact hold the ceteris too paribus? Or are there factors tending to cancel one another? Is the basic assumption about the relationship between background factors and policy incorrectly stated or simply inapplicable in the Central American situation? Or need we consider other matters heretofore ignored? Regardless of the failure of our alternate hypothesis in (1) to hold, our analysis is carried through to determine what, in fact, are the relationships among the social, economic and political milieux, the nature and scope of the policy process, and the policy outcomes in the polities of San José, Costa Rica and San Salvador, El Salvador in the fields of public housing provision and urban public finance.

The explanations for our findings are qualitative. They are based upon the historical, procedural and political analysis of the 
policymaking process as we see it carried out. We seek the causes of a particular occurrence at a particular point in the process. An ana1ysis of the interaction among the various policymakers, their policy preferences and resources, their roles and constituencies, will, we hold, provide up with an explanation, insofar as an explanation is possible.

The nature of the analysis carried out is influenced to some extent by the form of the data gathered. It is at times tempting to let the nature of the analysis be determined by the data, to simply gather whatever is available and later see what has been amassed and decide what to do with it. Tempting, yes, but such abstract empiricism is really not very satisfactory.

Amassing great reams of often unrelated but seemingly important data can easily become an end in itself, burying the true intent of the study. Or, in systems theory terms:

The information system, displaying the ingestive properties of a snake, swallows up the whole enterprise . . . The larger objectives of the system are obscured if not obliterated; the resources devoured; the total effort begins and ends with the dir a-gathering. 10

The relationship between data and analysis is a two-way street. One lane has been mentioned above but in the other lane a conception as to how the data is to be used governs the amount and type to be gathered. Finally, there are two operational considerations involved in this study. One is determining the extent to which policy analysis and the comparative approach are truly compatible and appropriate for an essay of this kind. We feel they are and explain why at some length in Chapter III. Nonetheless we realized there existed a possibility, how- 
iever slight, that this might not be the case. And to that extent, this study involves a refining of technique. It is also an attempt to devise, through constant backing and filling, a nonculture-bound framework for policy analysis, applicable in the developing as well as in the developed countries. Our particular choice of a model of the policy process was a first step in this direction; our concluding section suggests some modifications thereto. In any event, however, these considerations are decidedly secondary. The prime purpose of the study is to examine and compare the effects of the political, social and economic background factors on the policymaking process and its products in San Salvador and San José. 
1. Charles 0. Jones, "State and Local Public Policy Analysis: A Review of Progress," in Political Science and State and Local Government (Washington, D.C.: American Political Science Association, 1973), p. 34 .

2. El Salvador, Dirección General de Estadística y Censos, Censos Nacionales de 1971: Población, San Salvador, p. 71.

3. E1 Salvador, Direccion General de Estadística y Censos, Proyecciones de Población, 1969-1981, San Salvador, p. 23.

4. Population statistics, like many others, are not kept separately for the Municipality of San Salvador. These figures are for the urban area of San Salvador Department.

5. San José (Costa Rica) La Nación, 25 February 1974, p. 22A.

6. Costa Rica, Dirección General de Estadística y Censos, 1973 census, unpublished figures.

7. Gary W. Wynia, "Policy and Bureaucracy in Central America: A Comparative Study" (Ph.D. dissertation, University of WisconsinMadison, 1970), p. 88 .

8. Wynia, "Political Participation and Development Policy-Making: Latitudes and Disciplines in Five Central American Systems," (mimeographed).

9. Robert E. Agger, Daniel Goldrich, and Bert E. Swanson, The Rulers and the Ruled: Political Power and Impotence in American Communities (New York: John Wiley and Sons, 1964), pp. 73-78 passim.

10. Ida R. Hoos, Systems Analysis in Public Policy: A Critique (Berkeley: University of California Press, 1972), p. 12 . 


\section{CHAPTER I I}

\section{LITERATURE REVIEW}

North American and European scholars with interests in Latin America have traditionally confined their work to Mexico and South America. Central America, if considered at all, has been regarded simply as a narrow strip of land joining these and characterized by bananas, a dormant population and petty dictators. In fact it is about the size of Califormia and contains over 12 million inhabitants. Moreover, there are six separate republics, each with its own history and sociopolitical structure, each worthy of investigation. Despite this overall pattern of neglect by scholars, there have been some exceptions; some literature on tine area does exist. In this chapter we selectively sample the extant literature, both in English and in Spanish.

It is perhaps symptomatic of this traditional neglect that there exists no up-to-date general scholarly work on Costa Rica. The classic in this field, the Biesanz' Costa Rican Life, was written in 1944 . As it thus antedates postwar economic developments and more importantly the 1948 Revolution--the event from which all modern Costa Rican pol2 itical history is reckoned--this book's current utility is somewhat limited. Nonetheless, it is of sufficient importance that the Costa Rican Ministry of Culture translated the book into Spanish in 1975. (An earlier attempt at translation by Daniel Oduber, former President 
of Costa Rica, and Rodrigo Facio, Rector of the University of Costa Rica, was aborted shortly after its initial publication due to wartime paper shortages.) The Biesanz' concern with Costa Rica was more than academic; some years ago they moved to that country. It is possible that Costa Rican Life will be replaced as the classic work by The Costa Ricans, the result of a six-year study by Richard and Karen Biesanz that is scheduled for publication late in 1978.

There exists no agreed-upon classic covering El Salvador the way Costa Rican Life has covered Costa Rica for the last thirty years. However, Alastair White's recent work El Salvador may well attain this status. The author is a British sociologist but his writing is not characterized by the extreme narrowness of viewpoint and overreliance on jargon that pervades the bulk of American sociological scholarship. No particular bias is noticeable in his comprehensive treatment of Salvadorean history. He offers an interesting classification scheme for Salvadorean presidents of the last hundred years, characterizing them as pragmatic reformist, idealist liberal, pragmatic liberal, or conservative, and suggests that the prime difference between the two types of liberal is the economic emphasis of the pragmatist and the political concerns of the idealist. It might be enlightening to apply this scheme to other Central American presidencies within the same time frame.

White's description of how the official party wins elections, presidential and legislative, is a valuable piece of political analysis at least as sophisticated as any published by political scientists. On the economic side, he suggests that current economic policies and prac- 
tices, including industrialization, are lopsided and benefit only a minority. He points out a number of ways in which the money received by the lower economic sector of the population escapes from that sectoi, and how the rate of escape increases with increasing industrialization. In short, this is the most current, comprehensive and objective treatment of El Salvador available in English, albeit a certain Fabian cast is detectable in some of White's observations.

A recent short and very readable book on Costa Rican society and 5 politics is Charles Denton's Patterns of Costa Rican Politics. It has the merit of lacking the minutiae and turgidity of most books based on 6

Ph.D. dissertations. The book suffers, however, from being purely descriptive and in no sense analytic. The author concludes that:

The "democracy" that the PLN [Partido Liberacion Nacional] has done so much to create has gradually given way to deadlock between administrative and political organizations, between agencies within the administration, between parties in the legislature, between the prestige and the working class, and between the president and his government. Costa Rica's much admired democracy has contributed major stumbling blocks on the country's road to economic and social development.

He suggests that Costa Rica "could do much better if the political system was capable of exerting more control over its internal structure, its environment, and its resources and could tackle some of the nation's more basic developmental problems." Despite its shortcomings, especially some unsupported quantum leaps from data to often subjective judgments and conclusions, Denton's work does provide the best current brief picture of the Costa Rican political scene.

Another useful recent work on Costa Rican politics, although more limited in scope, is historian John Bell's Crisis in Costa Rica, The 8 Revolution of 1948. Perhaps Bell's greatest contribution lies in 
pointing out that José Figueres was actively engaged in organizing a revolutionary cadre prior to 1948 . This is a particularly enlightening contrast to the generally held view that the 1948 Revolution was a spontaneous reaction to the refusal of President Teodoro Picado and the calderonista ${ }^{9}$-dominated National Assembly to permit President-elect Otilio Ulate Blanco to take office. In further contrast to the general view of the 1948 Revolution as a purely Costa Rican internal matter, Bell places the event in the context of the Cold War and especially the United States-inspired wave of hemispheric anti-communism. Bell is obviously a supporter of Figueres and his National Liberation Movement and sometimes allows this enthusiasm to overcome dispassionate analysis of the Revolution and its immediate aftermath.

Unfortunately, no parallel works on the political development of El Salvador are to be found. From a public finance viewpoint, however, it is worthwhile to mention Henry Wallich's Public Finance in a Developing Country: El Salvador, A Case Study. In this work Wallich details the increasing rationalization of the Salvadorean tax system, the movement from dependence on excise taxes to greater use of income taxes. For the purposes of this essay, however, Wallich's work suffers from two major shortcomings. The first of these is age; the work was done 25 years ago. The second is the virtual ignoring of public finance in the inunicipal realm. "In view of the very limited importance of municipal finances, a few observations will suffice . . . No comprehensive statistical information is available for the financial activities of the municipalities . . It is believed, however, that this omission is not of great significance." 11 It is instructive to 
note the extent to which the national taxation system had been modified by the time the current study was carried out.

A particularly useful book in that it is one of the very few to make cross-national comparisons within Central America is Wynia's Politics and Planners: Economic Development Policy in Central America. His purpose was the discovery of patterns of innovation and their consequences for the policymaking process. He points out the general failure of planners in the five republics to achieve their public investment objectives and links this failure to the nature of their relationship to politicians and administrators, espcially the presidents.

In addition, he has compiled seven characteristics which he suggests "appear to form what might be termed the policy-making structure of the Latin American countries." These are:

1. Personalistic, and often charismatic, leadership juxtaposed with a lack of institutional, especially constitutional, legitimacy;

2. Expanding political participation, yet political underrepresentation of the urban and rural masses;

3. Administrative structures dominated by extensive patronage, intricate formal rules, and widespread informal disregard for formal rules;

4. Obscured and obstructed communications within the public sector and between the public and private sectors produced by weak information as well as by distrust and perscnal rivalries.

5. A heavy reliance on the private sector for managing but not not financing economic growth;

6. Slow economic growth and modernization because of numerous structural and institutional rigidities;

7. Economic dependence on foreign markets and, as a consequence, vulnerability to external economic and financial conditions.

He suggests further that these combine to give as paradigms 
personalistic leaders who direct patronage-ridden bureaucracies, enjoy weak communications with other power contenders, and receive inadequate information from government agencies and the private sector, yet must struggle to raise large revenues to supporf ${ }_{3}$ programs to expand their vulnerable and sluggish economies.

Policymakers are likely to be found at the extremes of the policymaking continuum. At one end are the overly cautious and underinformed proceeding in a hesitant manner to expand only marginally and incrementally their policy initiatives, guided by the maxim 'small risk, small loss.' At the other end are found the policymakers whose understanding of complex policy problems falls far short of their will to solve them, and who consequently grasp at thoroughly utopian and unrealistic policy schemes.

In the course of this essay we will determine whether or not the seven traits listed as national policymaking characteristics are mirrored in urban policymaking, and further, to see which of the ends of the policymaking continuum, if either, is occupied by the urban policymakers.

Samuel Huntington's Political Order in Changing Societies is of more than average importance for two reasons. First, it provides criteria which at least some segments of some 'developing' political institutions use to rate themselves, and second, it provides a broad cross-national view of various political phenomena such as praetorianism. An example of the former may be found in Costa Rica where the Instituto de Fomento y Asesoría Municipal (IFAM) ${ }^{15}$ specifically measured its own level of institutionalization in terms of Humtington's quartet--adaptability, complexity, autonomy, and coherence.

Praetorianism, the deliberate and open intervention of the mili- 
tary in the political process, is often regarded, especially by observers in whose homel and this phenomenon is rare, as being purely a manifestation of malevolence or perversity on the part of the military. Huntington suggests this is not necessarily so:

Countries which have political armies also have political clergies, political universities, political bureaucracies, political iabor unions and political corporations. Society as a whole is out-of-joint, not just the military. 17

Praetorianism has been a continuing and dominant part of politics in El Salvador. Much of this military participation, it is suggested, has had a salutory effect, such as the radical programs of social reform pushed by officers in the period following World War II. Although military intervention is the defining characteristic of praetorianism, it is not the only one. As Huntington points out: "A high correlation exists between student participation in politics and military intervention in politics. Both are distinctive characteristics of the radical praetorian society."

He observes further that a major difference, perhaps the major difference, between the military and other interest groups is capability. Monks, priests, students, workers and campesinos can demonstrate and protest but usually cannot govern. The military can do both. The understanding of praetorianism in general, and Salvadorean praetorianism in particular, provided by Huntington is of considerable utility to this essay.

The most promising title discovered in the preliminary search of the literature, Municipal Govermment in Costa Rica: Its Characteristics and Functions, turned out to be one of the more disappointing references. Data on characteristics of local government personnel, 
types of demands made on local government and decisionmaking of councils in terms of these demands were gathered, mainly by Costa Rican and United States university students. Unfortunately the various sorts of data were not well correlated. This probably reflects the emphasis of the project which was designed primarily to give the students field experience in data gathering.

A greater shortcoming from the viewpoint of this paper is the total ignoring of San José. (Interviews, perusal of council minutes and other data collection were carried out in and for 25 of the 76 cantons in Costa Rica.) This omission of San José, regrettably, characterizes much of the work on Costa Rican municipalities.

A genus of books generally valuable in the initial stages of research for a paper such as this is the anthology of readings on individual countries assembled in one volume. These readings may be by several authors, each dealing with one country, as in the collections edited by Martin Needler, and Ben Burnett and Kenneth Johnson, or all by one author as in the book by Harry Kantor. ${ }^{22}$ The selections may deal generally with politics and government in the separate countries, as in the works mentioned above, or the organization may be topical. The latter approach is adopted by Ronald McDonald who categorizes and relates nations according to party systems.

Of the three general works, the readings in Burnett and Johnson provide the most useful background, in part, at least, because they are the most recent. Paul Hoopes, writing on El Salvador, emphasizes the dynamism and inclination toward Central American regional integration that characterize the Salvadoreans, especially the economic and politi- 
cally potent. He maintains that the middle class is genuinely reformist, unlike other Latin American middle classes who wish only to displace and replace the current elites. He suggests further that this reformism manifests itself through the administration of the ruling military regime, leading to the erroneous conclusion on the part of some analysts that the military is itself reformist. Robert Tomasek, writing in this voliume, presents the standard view of Costa Rica as the one nation whose longstanding commitment to participatory democracy distinguishes her from most of the rest of Latin America. He points out, as one facet of this, Costa Rica is virtually unique in that its Legislative Assembly has de facto as well as de jure control over the majority of the important political decisions. Presidents of Costa Rica do not rule by decree.

The readings on Costa Rica in the other two books, by Kantor and James Busey, offer the same information but are given somewhat more to praise and less to analysis than Tomasek is. The sections on E1 Salvador, by Kantor and Charles Anderson, point out the industriousness of the Salvadorean people and, unlike Hoopes, suggest that the military itself is behind programs of social and economic reform. An indication of parallel approaches of these latter two sets of articles deserves mention. Busey subtitles his article on Costa Rica "A Meaningful Democracy"; Kantor calls his chapter "A Progressing Democracy." Anderson's subheading for his article on El Salvador is "The Army as Reformer," while Kantor labels his "The Military as Reformists." Kantor does include a 'Note on the Study of Comparative Government'; unfortunately his chapters are disjunct units with no attempt made at in- 
tegration or cross-national comparisons. He observes that his work is a snapshot at one point in time and concedes that it is impossible for himself or anyone else to "write a book describing Latin American government and politics and expect the description to be accurate for very long." 28

McDonald does not see either Costa Rica or El Salvador as loose multi-party systems of the anyone-has-a-chance-to-win variety. Costa Rica he characterizes as a multi-party dominant system. He points out that the Costa Rican Partido de Liberación Nacional (PLN) has maintained its majority in the National Assembly since 1953 as opposition to it has united and fragmented and reunited in different patterns. The PLN has not, however, been able to succeed itself in the presidency and hence is not characterized as single-party dominant.

Although a variety of parties contest elections in El Salvador, the Partido de Conciliacion Nacional (PCN) and its predecessor, the Partido Revolucionario de Unificación Democrática (PRUD) have maintained control of the Assembly and the Presidency since 1950. Some opposition parties have won seats in the Assembly since 1964 but they have not seriously challenged the hegemony of the official party. McDonald therefore classifies El Salvador as a single-party dominant system. The party structures and electoral patterns of both nations will be more closely examined in a subsequent chapter.

Costa Rica's PLN has itself been the topic of a number of works. Most often it is considered, as by Edward Williams for example, in the larger context of Latin American Christian Democratic parties. 30 The forerunner and model for these parties is of course the Alianza Popular 
Revolucionaria Americana (APRA), founded by Victor Raul Haya de 1a Torre in Mexico in 1924 but which was imported into Peru in 1930 and has since been identified with the latter country. Costa Rica has not, however, been plagued with many of the problems usually attacked by reformist parties of this type. Williams suggests that this has been a drawback for the PLN, and there has been a tendency towards increased conservatism on the part of its leadership.

Suzanne Bodenheimer puts the case even more strongly. She suggests that the PLN's ideology is fixated in the 1940s and must surely prove inadequate in the 1960s and 1970s. She maintains that the PLN currently appeals to the "security and complacency of the middle class" $^{32}$ rather than being directed, as it was initially, towards the emerging middle and rising lower classes. It is her conclusion that poor performances of recent PLN governments have been rooted in ideology rather than in administration.

One of the earliest articles to compare and contrast Costa Rica with another Central American republic was Busey's "Foundations of Political Contrast: Costa Rica and Nicaragua." 34 He supports the classic explanation for Costa Rican egalitarianism vis-a-vis Nicaraguan class distinction--the absence of mineral wealth in Costa Rica and its presence in Nicaragua. Further, he suggests that differences in the two political systems might be based in physical, ethnic, cultural and social integration or lack thereof, land tenure patterns, and even weather: "It can hardly be doubted that in some vague way the politics of Costa Rica may have benefited and that of Nicaragua may have suffered from climatic factors." 
It is often the case that articles of a broad philosophical nature or articles covering a wide range of countries contain bits and pieces of insight or information that can be usefully extracted. An example of the former is Ebel's "Governing the City-State." ${ }^{36}$ He sustains the argument here that one of the difficulties in the study; by Anglo-Americans (and some Europeans), of the governing of small Latin American nations, is the attempt by these outsiders to apply the political experience of their own nations to the Central American microstates. A more fruitful approach might be to consider these nations cities with hinterlands, with resources flowing from the periphery to the center for redistribution and control flowing from the core outwards to the peripheries. Our standard 'republican-pluralist' model is therefore an inappropriate framework for analysis. Ebel argues that this is particularly true for countries in his Group V, the smallest countries and those most dominated by a primate city. In this group, along with the island-sharing nations of Haiti and the Dominican Repub1ic, he includes Costa Rica and El Salvador.

Ebel also authored the single most useful article found on the policymaking process in a Central American city. In addition to analyzing decisions made in San Salvador, he provided one set of answers to the questions "Why study the urban centers in Central America?" and "Why not just get on with examining the national political systems?"

For Juan Gomez it is in the community and not in the nation where things happen. The plaza, bordered by church, market, and town hall, competes only with the cantina, the soccer field, and the cemetery as the focus of his life. And while the better-educated urbanite enjoys a wider vista, for many city people the barrio or the barranco [shantytown] pretty largely fills their horizon. Ultimately, whether for a cosmopolite or a parochial, the services which lighten the day and 
enliven the night are largely local in character. Sewage and water, iight and power, transportation, recreation and justice emanate from City Hal1. 37

Torres' "Measurement of Political Power" fits in the second cate38

gory of articles mentioned above. He obtained, by polling political scientists specializing in Latin America, estimates of the power, on a scale of $0-9$, heid by each of seven groups in each of the 20 Latin American republics. The seven groups were landed oligarchy, industrialists, campesinos, urban blue-collar workers, urban white-collar 39

workers, the military and the church. He then constructed Lorenz curves and calculated the Gini coefficients for each country. (Gini coefficients are discussed in Appendix B.) The higher the Gini ratio, the more concentrated was the political power in the country. Of the 20 countries, E1 Salvador was ranked ninth with a Gini ratio of .846 while Costa Rica ranked 18 th with a value of .673 . The extreme cases were Haiti with a Gini ratio of .929 and Cuba with a figure of .563 .

One final article to be mentioned here is Needler's "The Latin 40

American Military." He examined various military governments in Latin America to determine whether they were, as their detractors would have it, feudal and ruthless defenders of an oligarchical status quo or, as their advocates suggest, the one uncorrupted, technically competent apolitical force for change and development. The conclusion most relevant to this paper is: "The only plausible example of a modernizing military in the recent history of Latin America that has actually accomplished anything permanent is that of El Salvador."

This survey of literature in English is, to repeat, not exhaustive. Rather it indicates only some of the main pieces of scholarly 
writing that have proved useful to date in the construction of this essay. Many works consulted have not been included. A great many reports, technical works and data sources have not been indicated here; they are cited in other sections of the paper where their utility is more immediate. The same is true of the literature in Spanish. Cne of the advantages in researching a highly literate and welleducated Latin American country such as Costa Rica is that scholarly literature is available to the researcher in Spanish as well as in English. This is particularly useful when, as in the present case, the area has not received a great deal of attention from North American or British scholars. Unfortunately El Salvador possesses neither the tradition of critical self-examination nor the potential readership of Costa Rica, hence there is much less literature in Spanish dealing with the Salvadorean situation.

Two books that when read together provide a fairly complete background to the current political-legal situation in Costa Rica are Mario Alberto Jiménez" Desarollo Constitucional de Costa Rica ${ }^{43}$ and Joaquin Garro's Veinte Anõs de Historica Chica. Jimenez, one of his country's most noted jurists, traces the constitutional development of Costa Rica from independence through 14 fundamental documents to the 45 current constitution of 1949. He suggests that the differences between this document and previous constitutions are more profound than generally realized. Among these are a deliberate weakening of the power of the president, a redefinition of the role of the legislature with some weakening as a result, and a strengthening of the powers of the judiciary. In short, it takes a much more sanguine view of the na- 
ture of man and his capacity to prosper and live in peace without excessive government.

Garro examines essentially the 18 years between the revolution of 1948 and the elections of 1966. Chronologically, then, he picks up roughly where Jimenez left off. Garro is a former deputy to the National Assembly and considers this time span from a political viewpoint, regarding campaigns, elections and interparty deals as the major happenings of the period. His loyalty to the PLN is unquestioned; however he does raise, at least obliquely, some of the doubts Williams mentioned. Garro concludes:

We believe that the [electoral] fortune of the Party of National Liberation depends in large part on the message it can give to or the impact that it can have on its old clientele: campesinos, inhabitants of rural areas and the lower-middle class, integrated with the professionals, small merchants, skilled or semi-skilled workers and white-collar workers. Nevertheless, if for these [groups] Calderón Guardia should disappear, the political situation will be for National Liberation more fluid and plastic: the Calderonistas will feel free to choose their party and many of these could be inclined toward that party [PLN] as occurred in 1966.46

He turns out to be a reasonably accurate predictor of the 1970 election.

A realistic look at important influences on policy formulation is 47

Oscar Arias Sánchez' Grupos de Presión en Costa Rica. In this work Arias uses a standard framework for defining and delimiting pressure groups. He lists the most active ones in Costa Rica and identifies their sources of strength. The actual role of some of these groups in influencing specific policies is traced. Arias regards pressure groups as intrinsically undesirable and worries that individual and isolated legislators may not be able to stand effectively against them. The 
cure for this malady, he concludes, is an ongoing system of strong, disciplined, permanent, ideologically-based political parties in whose bosoms the legislators can find strength, reinforcement and guidance. Conventional wisdom about Costa Rica has it that because the 1 and had no mineral riches or tractable Indian population no class of landed gentry developed. As a result the nation has a more equitable land tenure system; hence a fairer distribution of wealth, hence a very open political system with broad participation and wider distribution of power than is the case in most Latin American nations. Without disputing the economic and historical preconditions, Samuel Stone Zemurray suggests major political offices are held by a much smaller and more interrelated group than is generally realized. In a provocative arti48 cle, he argues for the importance of blood. He points out that 33 of the 44 presidents have come from only three families, those of Juan Vásquez de Coronado, Nicolás de González y Oviedo and Antonio de Acosta 49

Arévalo. Together with the family of Jorge de Alvarado, these families have provided 550 out of the 1,300 members who have been elected to the Legislative Assembly since 1821. Foremost among these families is that of Vásquez which has supplied no 1 ess than 19 presidents and some 230 deputies of all ideological persuasions.

Works in Spanish on Costa Rica and its municipal system are not limited to those printed in Costa Rica; a few articles are to be found in foreign journals. Examples of these are the articles by JorgeEnrique Romero Pérez appearing in the Madrid-based Revista de Estudios 51

de. la Vida Local. In these pieces Romero outlines the principal purposes, structure and financing of IFAM and indicates the background to 
and some of the major provisions of Costa Rica's first (1970) Municipal Code. Both of these articles are basically descriptive and generally laudatory rather than critical and analytical.

A genre of literature that proved singularly useful was the graduate thesis. These theses were primarily from the Faculties of Law and Economic and Social Sciences at the University of Costa Rica. Three of these deserve specific mention: Lilia Montero, Evolución del Sistema Tributaria de Costa Rica; Luis Ramirez, Investigación de los Servi$\frac{\text { cios Publicos Brindados por las Municipalidades y Sus Lineas de Ac- }}{53}$ ción; and Jose Vargas, Administración del Sistema Municipal in Costa 54 Rica.

Montero examines the taxes in force in 1969 and 1970 , considering the various bases and tax rates, whether or not earmarked and their destination--central government, autonomous agencies, municipalities or the private sector. She also indicates the statute or administrative directive establishing each particular tax, and the date enacted. By providing figures for 1950 through 1970 she makes it possible to determine shifts in emphasis on the various tax sources. At the end of this 20-year period, for example, taxes on external commerce were only onehalf as important as they had been at the beginning, while taxes on internal economic activities became more important. She points out, moreover, that the efficiency of collection has increased markedly; administrative costs dropped from a high of $5.47 \%$ of total collection in 1963 to a low of $1.67 \%$ in 1970 , the last year for which figures are avail55

able. The detailed tax data in her appendices are the most complete available from any single source. 
Ramirez' work is an essentially empirical impressionistic examination of the actual administration of a number of small municipalities. He is highly critical of what he found. In one anecdote he relates how he asked to look at the books in one small town--a legal right--but found it impossible because an employee who was absent had the only set of keys to the desk in which the books were kept. Ramirez listed a number of problems, some administrative and some political, which beset the municipalities. Among the former were employees who routinely failed to show up at work and who did nothing while in the office, a constant changing of treasurers and accountants, too many different offices to be visited by citizens with relatively simple business to conduct and an almost complete lack of coordination among various municipal offices and between the municipalities and the central government and the various autonomous agencies. He listed 13 of these agencies with which the municipalities regularly dealt.

Political problems included unwarranted interference in day-today activities by the councillors and municipal executives, the lack of requirements for the office of municipal executive and a lack of both long- and short-term planning. 56 Ramirez maintained moreover that the councillors traditionally set charges that were too low to cover service costs. He offered two reasons for this: timidity, and the fact that many councillors would be looking for votes among the taxpayers when they were running for deputy or other higher elected office. As immediate and pragmatic solutions for some of the more obvious problems, he suggested the hiring of more qualified people, paying them commensurately and insisting they work full-time, the keeping of a complete set 
of keys in the municipal office, and the use of bookkeeping machines.

Vargas began his work with an appreciation of the steadily diminishing role of the municipality in the framework of government. He first thought, in fact, that he would be chronicling the liquidation of local government and indicated three major reasons for this:

The loss of autonomy suffered by the Local Governments is directly related to three phenomena: 1)Archaic legislation, 2) lack of financing, and 3 ) the necessity of upgrading the quality of the personne1. 57

His findings as to the insufficiency of user charges and their nonpayment through administrative ineptness closely parallel those of Ramirez. Vargas states: "We have never known [of a case] where a municipality has charged excessive amounts for services rendered, or where properties have been forfeited for failure to pay [taxes].

His own preference is for local government vastly strengthened at the expense of national government. He goes so far as to argue for the municipality as primary tax collector, with monies not needed locally made available for national government expenses. The actual situation in Costa Rica remains the reverse of this, however. Vargas sees a definite strengthening of the municipality which he attributes to three acts of the National Government: Law 4340, which provides for the participation of municipalities in the sharing, to a known and expanded extent, of certain nationally collected taxes; the new Municipal Code (Costa Rica's first); and the creation of IFAM. He succinctly characterizes the municipalities thus: 
Economic situation

Legal base

Budget system

Accounting system

Control
Insufficient

Magnificent

Good

Bad 59,60

Acceptable

The final Spanish language source to be considered here, dealing with Costa Rica, is Volume 20 (1972) of Revista de Ciencias Jurídicas, a journal published by the University of Costa Rica School of Law. This entire volume is devoted to various legal aspects of the Costa Rican municipal system with emphasis on changes contained in the new (1970) Municipal Code.

Municipal autonomy, the Municipal Code and subventions from the national government are discussed in the first article, by otto Rojas. The author, a lawyer like most of the other authors in the volume, is currently a member of the Supreme Administrative Tribunal for Costa Rica. He gives a very brief history of the Costa Rican municipality and considers whether municipal autonomy is mere administrative decentralization or something more. After a lengthy legalistic discussion, he suggests the autonomy possessed by the municipality in its sphere of action is more than that granted to the autonomous agencies but less than that reserved to the central government. Autonomy is, in short, quite imprecisely defined.

Rojas argues that the appropriate division of activity is for the national legislature to determine what, in fact, is local in nature and once this is done, each municipality is to deal with local matters as it deems fit. In this way diversity can be accommodated within the general policy aims of the central government. He concedes, however, that the municipality as currently constituted is ill-prepared to carry out such 
responsibilities and recommends certain structural reforms, including fewer and larger municipalities, that will enable local government to play its rightful role. He suggests further that a complete examination of local financing is necessary to determine not only the proper level of national to local government transfer payments but also the correct sharing and distribution of revenue sources.

In a brief essay, Manuel Castro deals with the taxing powers of the municipal and national governments and the relationships between 62

these. He indicates the limited types of levies the Municipal Code allows municipalities to collect--charges for paving sidewalks, lighting and cleaning of streets and the like. He emphasizes the severe restrictions on the power of the municipality to raise revenue, particularly the provision that any new municipal tax or change in tax rate requires the approval of the Comptroller General and/or the legislature. Castro concludes by pointing out that any cases not covered by the Municipal Code are covered by the Taxation Practices and Procedures Code.

A very broad article by Eduardo Sancho, Chief of the Legal Department of the Municipality of San José, examines the relationships between municipal functions as laid out in the Municipal Code and what he terms the Costa Rican municipal reality. ${ }^{63}$ He begins by viewing the municipality in three different ways--as a socio-historical entity, as a legal entity and as a political entity. This is followed by a chronological discussion of the Costa Rican municipality and its antecedents; from the Roman municipium through Visigoth settlements, the Spanish ayuntamiento of the 17th and 18th centuries, the municipality in colonial American and early independence to the present. Abruptly shifting gears, Sancho 
considers short, medium, and long term objectives of the municipality, and its duties and attributes, whether exclusive or concurrent.

In an interesting aside he discusses the sticky issue of antinomy-the conflicts, apparent and real, between two laws. In this particular case it refers to conflicts between provisions of the Municipal Code and those of other laws, especially regarding matters of concurrent responsibility such as public health, tourism, education and socioeconomic development. Sancho states:

Repeatedly we observe that functions for which responsibility is shared remain moribund and do not produce the benefits the communities expect from them. Each institution transfers the problems to the co-responsible institution, without offering solutions and this, of course, generates a mood of insecuity in the citizenry. 64

As a solution he suggests the redefining of municipal and national $\mathrm{ju}-$ risdictions to eliminate concurrence, along with adequate financing for the municipalities. With the new Municipal Code, Sancho concludes, things are getting better, the municipalities are being strengthened.

This article did not delve deeply into any of the vast array of inatters it addressed. Moreover, it did not engage in precise niceties of legal reasoning on technical points. It did provide probably the best introduction available to the multifaceted Costa Rican municipal system, whether it be considered from a historical, political, legal or administrative viewpoint.

Mauro Muri110, Professor of Public Law at the University of Costa Rica and Parliamentary Counsel to the Legislative Assembly, addressed 65 his essay to neighborhood participation in local government. He points out that unlike national government, local government is susceptible to direct as well as indirect participation. Any person at least 
18 years of age, in possession of political rights, and a resident of the canton, has a variety of ways of affecting local government directly. Among these are the cabildo or open meeting which is oral and advisory; plebiscites, a yes or no vote written and binding upon the municipal council; and referenda, ratifying acts already passed by the council.

To facilitate citizen participation in municipal policymaking, the Municipal Code, which Murillo helped draft, requires that all projected municipal acts be published in the Official Journal, and further, that no less than ten working days after such publication, a public hearing must be held. Any citizen-resident has the right to appear and speak at these hearings. Internal rules and procedures of the council are exempt from these requirements. Murillo points out, however, that all of these provisions are no guarantee that legislation unacceptable to the majority of the inhabitants will not be passed. One reason for this is that cabildos, plebiscites and referenda are called only by the council itself; the council may do this, it does not have to. Another is that the Official Journal, like journals of record in many countries including the United States, are often not readily accessible. Yet a third factor is the tendency of the residents, both in Costa Rica and internationally, towards apathy in matters of local government.

The final article in this set deals with current and recommended 66

municipal revenue practices in Costa Rica. The author, Joao de Moraes, is a Brazilian specialist in municipal administration who was on loan to IFAM. This will not be discussed further here; it is examined at some length in the section below dealing with public finance. 
As mentioned above, the scholarly literature in Spanish dealing with municipal finance, government and policymaking in El Salvador is much less extensive than that dealing with similar concerns in Costa Rica. In fact, only two works will be considered here. The first of these, by Alberto Harth Deneke, j.s a fairly technical look at the development of city plans for San Salvador in the period 1954-1973. He notes the changes in them, the progressively greater comprehensiveness and the degree of their implementation or lack thereof. The current plan itself will be examined below in Chapter V.

Fide1 Chávez Mena's Organización Municipal is much broader in scope than the average doctoral thesis in law. It combines political philosophy and partisan political ideology (Partido Demócrata Cristiano--PDC) with a legal and administrative analysis of the Salvadorean municipal system, concentrating on San Salvador. It accurately reflects Dr. Chávez' own career as practicing attorney, PDC stalwart and long-time San Salvador city councillor. As a philosophic viewpoint, Chávez maintains: "The State is no more than the result of the organic structure of the local communities" and immediately projects this viewpoint into the Salvadorean situation:

It is inconceivable to pretend to obtain efficacy in municipal administration if the municipality finds itself limited in a centralist political order in which its activities are limited to the merely mechanical [ones] of providing services regulated by and dependent economically upon subsidies provided by the will of the central government. 69

He maintains further that no state that deliberately weakens or attempts to abolish the municipality can be called democratic.

Not content with analyzing or philosophizing about the municipality and its relations with the nation, Chávez takes the central govern- 
ment to task for certain specific practices. He criticizes its limits on municipal spending as unrealistic, citing the fact that a municipality must solicit permission to buy a simple desk. He censures the national government for having allowed private enterprise to compete with the municipalities in the provision of user-chargeable municipal services. Two further indictments charge that the central power plays partisan politics, favoring municipalities with a PCN government and that, despite enabling legislation, there exists no agency to provide either financial or technical assistance to the municipalities. (In Costa Rica IFAM carries out these activities.) In short, Chávez combines a scholarly legal and administrative analysis with a partisan attack on a central government and official party he feels arc deliberately enervating his city.

This review does not include all the literature in existence on Costa Rica and El Salvador. It does not even encompass all the literature used in the preparation of this paper. It does, however, provide a broad and representative sample of what scholars have written concerning these two countries.

In summary, it presents a general description of the two polities. Costa Rica is indisputably more open politically, more advanced economically, and more thoroughly examined by scholars than is El Salvador. It is with this general background in mind that Chapter $V$ examines more specifically the political, economic and social conditions; Chapter VI considers the policy process; and Chapter VII describes the current programs in the fields of public housing and municipal finance in the two countries and their capital cities. 
CHAPTER II NOTES

1. John and Mavis Biesanz, Costa Rican Life (New York: Columbia University Press, 1944).

2. See Joaquin Garro, Veinte Años de Historica Chica (San José: Imprenta Vargas, 1967).

3. Alastair White, El Salvador (New York: Praeger Publishers, 1973). Another recent general treatement, this one from a cultural geographer's point of view, is David Browning's El Salvador: Landscape and Society (London: Clarendon Press, 1974).

4. A very different viewpoint of El Salvador as a protean economy may be found in David Raynold's Rapid Development in Small Economies: The Example of El Salvador (New York: Frederick A. Praeger, 1967).

5. Charles Denton, Patterns of Costa Rican Politics (Boston: Allyn and Bacon, Inc., 1971).

6. Denton, "The Politics of Development in Costa Rica" (Ph.D. dissertation, University of Texas at Austin, 1969).

7. Denton, Patterns, p. 107.

8. John Bell, Crisis in Costa Rica, The Revolution of 1948 (Austin: The Institute of Latin American Studies, 1971).

9. Calderonista is the term applied to the followers of Rafael Angel Calderón Guardia, President of Costa Rica 1940-1944, political mentor of Picado, and defeated presidential candidate, 1948.

10. Henry Wallich et al., Public Finance in a Developing Country: E1 Salvador - A Case Study (Cambridge: Harvard University Press, 1951).

11. Ibid., p. 56 .

12. Wynia, Politics and Planners: Economic Development Policy in Central America (Madison: University of Wisconsin Press, 1972).

13. Ibid, , pp. 5, 6 .

14. Samuel P. Huntington, Political Order in Changing Societies (New Haven: Yale Lniversity Press, 1968).

15. There exists a plethora of public and private agencies in Costa Rica 
and E1 Salvador that are almost universally known by their initials or similar acronym. These will be named in full the first time mentioned and thereafter referred to by the short form. English equivalents are provided in the glossary.

16. Huntington, Political Order, p. 12.

17. Ibid., p. 194.

18. Ibid., p. 210 .

19. Christopher E. Baker, Ronald Fernandez Pinto and Samuel Stone Zemurray, Municipal Govermment in Costa Rica: Its Characteristics and Functions (San José: Associated Colleges of the Midwest Central American Field Program and School of Political Science, University of Costa Rica, 1971).

20. See Luis Ramirez Zamora, "Investigación de Los Servicios Publicos Brindados por Las Municipalidades y sus Lineas de Acción" (Graduating thesis, Faculty of Economic and Social Sciences, University of Costa Rica, San José, 1972).

21. Martin C. Needler, ed., Political Systems of Latin America (Princeton, New Jersey: D. Van Nostrand, Inc., 1964); Ben G. Bumett and and Kenneth F. Johnson, eds., Political Forces in Latin America: Dimensions of the Quest for Stability, 2nd ed. (Belmont, California: Wadsworth Publishing Co., 1970).

22. Harry Kantor, Patterns of Politics and Political Systems in Latin America (Chicago: Rand McNally and Co., 1969).

23. Ronald H. McDonald, Party Systems and Elections in Latin America (Chicago: Marknam Publishing Co., 1971).

24. Paul R. Hoopes, "El Salvador," in Burnett and Johnson, Political Forces, pp. 95-114.

25. Robert D. Tomasek, "Costa Rica," in Burnett and Johnson, Political Forces, pp. 131-158.

26. Kantor, "Costa Rica," in Kantor, Patterns, pp. 187-227; James L. Busey, "Costa Rica," in Needler, Political Systems, pp. 132-149.

27. Charles W. Anderson, "El Salvador," in Needler, Political Systems, pp. 70-91; Kantor, "El Salvador," in Kantor, Patterns, pp. 107-123.

28. Kantor, Patterns, p. xi.

29. The 1974 Costa Rican election completely reversed this. The PLN, for the first time, lost its absolute majority in the Assembly and captured the presidency for a second consecutive term. Given the relative powers of the President and the Assembly, this can likely 
be regarded as an overall weakening of the PLN position. However, it is still accurate to refer to Costa Rica as having a multi-party dominant system.

30. Edward J. Williams, "The Partido Liberación Nacional of Costa Rica," in Edward J. Williams, Latin American Christian Democratic Parties (Knoxville: University of Tennessee Press, 1967), pp. 217232 .

31. Suzanne Bodenheimer, "The Social Dernocratic Ideology in Latin America: The Case of Costa Rica's Partido Liberación Nacional," Caribbean Studies 10 (1971):49-96.

32. Ibid., p. 87 .

33. There is a paucity of similar literature examining PRUD-PCN in E1 Salvador. A peripherally related journalistic impression may be found in Paul Kennedy, The Middle Beat: A Correspondent's View of Mexico, Guatemala and EI Salvador (New York: Teachers College Press of Columbia University, 1971). An earlier work comparing PRUD and PLN as movements and the economic development policies associated with these is Charles Anderson, "Politics and Development Policy in Central America," Midwest Journal of Political Science 5 (1961): 332-350. This article also considers the Castillo Armas administration in Guatemala.

34. Busey, "Foundations of Political Contrast: Costa Rica and Nicaragua," Western Political Quarterly 11 (1958):627-659. Busey has been one of the most prolific writers on Costa Rica. In addition to this article and the section in Needler (note 26 supra), he has authored "The Presidents of Costa Rica," The Americas 18 (1961):55-70, and Notes on Costa Rican Democracy (Boulder: University of Colorado Press, 1962).

35. Busey, "Foundations," p. 651.

36. Matthew Ebe1, "Governing the City-State: Notes on the Politics of the Small Latin American Countries," Journal of Interamerican Studies and World Affairs 14 (1972):325-346.

37. Ebel, "The Decision-Making Process in San Salvador," in Francine Rabinowitz and Felicity Trueblood, eds., Latin American Urban Research Volume I (Beverly Hills: SAGE Publications, 1971), p. 189.

38. J.F. Torres, "A New (and Partial) Approach to Measurement of Political Power in Latin American Countries," Western Political Quarterly 26 (1973): 302-313.

39. His survey included an eighth group, foreign investors, but was omitted from the final calculations due to the nature of his methodology. 
40. Needler, "The Latin American Military: Predatory Reactionaries or Modernizing Patriots," Journal of Inter-American Studies 11 (1969): 237-244.

41. Ibid., p. 242 .

42. Examples of the sorts of works consulted but not reviewed or cited are Harold Williams, "Power Structure and Its Communication Behavior in San José, Costa Rica," Journal of Inter-American Studies 9 (1967) :236-247; Robert Williamson, "Some Factors in Urbanism in a Quasi-Rural Setting: San Salvador and San José," Sociology and Social Forces 47 (1963):187-200; Christopher Baker, "The Costa Rican Legislative Assembly: A Preliminary Evaluation of the Decisional Function," in Weston Agor, ed., Latin American Legislatures: Their Role and Influence. Analyses for Nine Countries (New York: Praeger Publishers, 1971); and John Martz, "Costa Rican Electoral Trends 1953-1966," Western Political Quarterly 20 (1967):888-909.

43. Mario Alberto Jiménez, Desarollo Constitucional de Costa Rica, 2nd ed., (San José: Editorial Costa Rica, 1973).

44. Garro, Veinte Años.

45. Or 16, depending on how one chooses to regard the Constitution of Cadiz and the Fundamental Social Pact which overlapped the colonial and early independence periods.

46. Garro, Veinte Años, p. 116.

47. Oscar Arias Sánchez, Grupos de Presión en Costa Rica (San José: Editorial Costa Rica, 1971).

48. Samuel Stone Zemurray, "Algunos Aspectos de la Distribución del Poder Político en Costa Rica," Revista de Ciencias Jurídicas (RJC) 17 (1971): 105-130.

49. Since the 1974 election, 34 out of 45 .

50. The dominance of this clan has been even more marked after the Revolution of 1948. Since then it has provided five of the seven presidents, José Figueres and Otilio Ulate being the exceptions. The immediate past president, Daniel Oduber Quiros is yet another descendant of Vasquez. Several vice presidents and presidential candidates are also included. It is not unknown for a presidentelect and his two closest rivals for the office all to be descended from Vasquez.

51. Jorge-Enrique Romero Pérez, "El Instituto de Fomento y Asesoria Municipal de Costa Rica," Revista de Estudios de la Vida Local (REVL) 179 (1973) and "E1 Primer Codigo Municipal de Costa Rica," REVL 177 (1973) . 
52. Lilia Maria Montero Umaña, "Evolución del Sistema Tributaria de Costa Rica y Analisis Económico de Algunas Impuestos al Consumo Interno" (Graduating thesis, Faculty of Economic and Social Sciences, University of Costa Rica, San José, 1972).

53. Ramirez, "Investigación de Los Servicios Publicos."

54. José Angel Vargas Oviedo, "Administracion del Sistema Municipal en Costa Rica" (Graduating thesis, Faculty of Economic and Social Sciences, University of Costa Rica, San José, 1972).

55. Montero, "Evolución de1 Sistema Tributaria," p. 128.

56. The municipal executive was appointed by the central government, not elected by the municipal voters. He could be, therefore, and often was, both uninterested in municipal affairs and of a different political party than the one governing the municipality. The nature of this position was, however, altered in the Municipal Code of 1970 .

57. Vargas, "Administración del Sistema Municipal," p. 3.

58. Ibid., p. 5 .

59. Ibid., p. 95 .

60. Besides the theses mentioned in greater detail above, others consulted were: in Economic and Social Sciences, Carlos Brenes Villar, "Aspectos Historicos Jurídicos del Régimen Municipal Costarricense" (1970); José Castro Carvajal, "Evaluación del Sistema Presupuestario de Costa Rica" (1969); Gonzalo Garcia Vargas, "Control Económico Fianciero de Las Municipales Costarricense" (1966): in Law, José Meza Araya, "La Potestad Reglamentaria Municipal" (1972); Mercedes Solorzano Saenz, "El Hecho Generador de la Obligación Tributaria" (1971); Johnny Vega Calvo, "Régimen Jurídico de la Prestación de Servicios Publicos Locales" (1965): in Sciences and Letters, CeciIia Rodriguez Monge and Elena Ferrer de Beck, "Aspectos Historicos y Urbanoz del Area Metropolitana de San José de Costa Rica" (1967): and in Social Sciences, Olga Martinez Calvo de Angelé," Problemas Socio-Económicos Que Affectan al Peon de la Municipalida de San José" (1972); all at the University of Costa Rica, San José.

61. Otto Rojas, "E1 Código Municipal y 1a Municipalidad Autonoma. Subvenciones y la Autonomia Municipal," RCJ 20 (1972):9-56.

62. Manuel Angel Castro L., "Normas Tributarias del Código Municipal y sus Relaciones con el Nuevo Código Tributaria," RCJ 20 (1972):57-62.

63. Eduardo Sancho Gonzales, "Las Funciones Municipales (Articulo 4 del Codigo Municipal) y la Realidad Municipal Costarricense," RCJ 20 (1972):53-103.

64. Ibid., p. 95 . 
65. Mauro Murillo, "Participacion de los Municipes en el Gobierno Local," RCJ 20 (1972):105-113.

66. Joao Luiz de Moraes Barreto, "En Busca de una Teoria de Reforma Tributaria Municipal en América Latina," RCJ 20 (1972):115-128.

67. Alberto Harth Deneke, "1954-1973: 20 Años de Planes para San Salvador," Revista Interamericana de Planificación 7 (1973):64-76.

68. Fidel Chávez Mena, "Organización Municipal" (Doctoral thesis, Faculty of Jurisprudence and Social Science, University of El Salvador, San Salvador, 1966).

69. Ibid., pp. 28, 29. 


\section{CHAPTER III}

\section{POLICY ANALYSIS}

As indicated in Chapter I, the two key research techniques adopted in this study are policy analysis and comparative examination. In this chapter the various elements thereof are more thoroughly explicated.

First, the nature of the policymaking process and frameworks for its analysis are considered. Second, our particular model of choice is presented. Third, following from the previous two sections, is an explanation as to why the policy approach is used here. Fourth, the tradition of scholarly examination of the policy process is traced. Finally, the nature and applicability of the comparative approach are discussed. In Chapter VI, specific policy developments in San José and San Salvador will be analyzed and compared.

\section{NATURE OF THE POLICY PROCESS}

It is well at the outset to present our working definition of policy, for probably no word in current social science literature is more used or less defined. One prominent author in the field, however, holds this to be no bad thing. Ira Sharkansky has written, "It would be futile and misleading to work toward a clear definition of policy, policy process, or policy-making." ${ }^{1}$ When it is defined, policy, like kachina, is as often defined in terms of what it is not as in terms of 
what it is. Stuart Rakoff and Guenther Schaefer have pointed out that unless further specified, policy may describe

the general or specific norms, goals, objectives or actions pursued by the political systems, or it may refer to the instruments or strategies devised to realize these goals, or to the actual actions and concrete steps of implementation. 2

For the purposes of this study policy will be defined, following Rakoff and Schaefer, as "the action or nonaction of a political system in response to demands made upon it." ${ }^{3}$ Such action or nonaction can take a variety of forms, from simple statements of intent to actual implementation or termination of particular projects.

Underlying all policy analysis is the concept that decisionmaking is a process, a process that can be traced. Thomas Dye suggests six perspectives from which public policy may be examined: systems theory, elite theory, group theory, rational decisionmaking theory, incremex:4 talism, and institutionalism. The perspective adopted here is primarily systems theory, although elements from some of the others do appear from time to time. In David Easton's terminology there is a political system that receives inputs, demands and supports, and eventua1ly translates them into outputs. Policy analysis attempts to open the "black box" that is the political system and examine this transformation of inputs, particularly demands, into outputs. We are dealing here with public policymaking, studying demands on a governmental entity or entities, and the way in which these demands are, or are not, translated into some sort of governmental response.

Frameworks for the analysis of public policymaking abound. They vary in terminology, complexity and occasionally boundary definition but are essentially parallel. Almost all take as their input demands, 
some include supports. Each of these frameworks is designed to enable the analyst to follow a demand from its genesis through a series of stages to either its emergence as a policy or its falling by the policymaking wayside.

In a typical analytic framework, the first stages are the individual perception of some environmental condition and the defining of this condition as an imperfection, a state wanting change. The individual is faced at this point with three choices: he can, if possible, change it himself, privately; he can forget it; or he can seek public activity to change it. At this juncture the perceived problem is still outside the political system, only a small proportion of these potential demands ever enter thereunto.

As John Dewey points out, the usual alternative to private action is not public action but either inaction or "routine, impulsive and other unreflected acts also performed by individuals." Daniel Elazar reinforces this position and says of public officials that they are normally not willing to initiate new programs or open up new areas of government activity on their own recognizance. They will do so when they perceive an overwhelming public demand for them to act, but only then. ${ }^{7}$

This perceived condition, defined as a problem, is then often aggregated with similar ones, at least this is held to be the case in 'developed' nations for which most policy analysis frameworks have been designed.

Already some major difficulties with these frameworks appear. At what point does the the problem become a demand, before or after aggregation? Does this aggregation take place inside or outside of the boundaries of the political system? What, in fact, are the boundaries 
of the political system, and how are they chosen? Easton suggests that the system boundaries are determined heuristically by the analyst:

Accordingly, what we choose to put inside our system to consider within its boundaries, will depend upon what we wish to examine in detail; for scientific purposes we also expect that these variables will show considerably interrelationship and coherence. What we leave outside, as part of its environment, will be those factors that we can accept as givens. They represent the independent variables or parameters of the system. 8

At this point the agreement among the various schema for policy analysis begins to break down. Jones, for example, holds that the problem does not become a demand nor enter the political system until not only aggregation but organization and representation as well have taken 9 place. Rakoff and Schaefer, on the other hand, maintain that individual needs enter the political system which may then process them into demands and, in order to avoid overloading itself, aggregate these de10

mands. Demands, however, are not necessarily aggregated; some may be summarily dropped by the political system, a few others may be strong enough by themselves to warrant further consideration. William Riker posits that the usual course is for demands to aggregate until there are only two, conflicting demands, or more precisely, coalitions of demands between which the policymaking system will eventually choose.

This stage of the policy process is far from neat but we attempt to summarize. Differing perceptions of the environment lead to differing definitions as to what sorts of activity, if any, the political system might undertake. Only a few of these perceived needs or problems ever formally enter the political system as demands, but even this small proportion are so different and in such conflict as to require the system, in self defense, to aggregate them. For the specific in- 
terest areas of this study a purely empirical approach is taken. That is, the formal government structure is examined to see at what point it first takes cognizance of the particular issues involved.

Standard policy analysis frameworks encourage, and research in 'developed' nations emphasizes, these inputs into the political system. And this is appropriate in those nations where we1l-developed political parties and interest groups engage in the articulation and aggregation of interests, whether seeking policy changes or in support of the status quo. But as Thomas Smith points out, "in many African and Asian political systems interest groups and political parties may be weak, inarticulate, or even abolished by action of the government." ${ }^{12}$ This may not be the case in Costa Rica or E1 Salvador but it does raise by implication another major question, What happens when all important perceptions of problems and presentation of demands come from within the political system? This, we maintain, is likely to be the case in the two polities under study here. Such an occurrence does not invalidate the policy approach but extra care must be taken to recognize it when it happens.

If the political systems of developing nations may lack these specific inputs, they may possess, willingly or otherwise, extra inputs from without the system. We refer here, of course, to international influences. Consider for a moment the vast number of economic and social development programs undertaken by the United State alone, and the direct influence these can have on the policy processes of cooperating or client nations. Not only money but also technical personnel can influence policy choice. And it is not unknown for two foreign agencies, 
from the same nation, to be working at cross purposes within a single polity. For example, in a small country, the presence of financial and technical aid and influence from the Agency for International Development, the Peace Corps and the World Bank may indicate the magnitude of this intervention and the possible policy effects. With the simultaneous presence of multinational corporations the external constraints on internal policymaking in developing countries such as El Salvador and Costa Rica become even more important.

Returning to the standard framework for policy analysis, we find the perceived problem has become a formal demand and entered the political system, there to be acted upon. The next stage in the process is policy formulation, the actual development of a plan for solving the problem, for responding to the demand. This stage is often regarded, particularly in the 'developed' nations, as the single most critical part of the policy process. At this point decisionmakers have essentially three tasks--they must enumerate the alternatives available, they must evaluate these alternatives, and finally they must select, or adopt, one of these alternatives.

Ideally, the policymakers will engage here in optimal decisionmaking. That is, they will study and debate thoroughly every policy alternative until eventually one will emerge as the absolute best that can be achieved. It will not only be the optimal policy in and of itself but will also reflect the allocation of precisely the right share of resources in relation to all other policy alternatives of whatever kind being considered during the same time frame by the political system. More likely, however, the policymaking will be of the type termed 
by Yehezkel Dror satisfying and by Herbert Simon satisficing. That is, the policymakers will determine beforehand what will be a satisfactory level of response to the demand with which they have been presented and will adopt the first alternative which satisfies that criterion, regardless of whether or not it is the best response. This practice is much more amenable to the omnipresent scarcity of resources, including the time available to the decisionmakers and their lack of perfect knowledge.

A policy has been adopted. In the usual framework it now undergoes legitimation. Legitimation is a dual process. On the one hand the policy must be examined to determine that it is in accord with accepted standards; in United States' parlance, Is it constitutional? And in the case where the policymaking unit is a subnational government, e.g., the Municipality of San José or San Salvador, the policy must be in agreement with the wishes, expressed or implied, of the national government. In addition, if implementation of the policy is going to require funds from a foreign source, e.g., funding to build public housing, the policy must also meet the guidelines of the funding agency. On the other hand, the policy must be legitimated to the public at large. The people, or at least a large and influential enough segment of them to ensure the political feasibility of the program, must be prepared to accept it.

Not every member of a polity plays an equal part in public policymaking. In authoritarian systems most of the public is involuntarily excluded from the process. In the more open systems, the public is generally content, for a number of good reasons, to choose the 
proximate policymakers, give them some sort of vague mandate, and let them go about their business. The most formal of the policy analysis models assume that specific roles in the process will be played by specific actors. The separation of powers model to which decisionmaking in the United States is supposed to adhere gives to the Iegislative branch the formulation and adoption stages, to the judiciary the legitimation stage (in the legal sense) and to the executive the implementation stage.

Inputs at these stages from other than the proximate policymakers appropriate to each stage are often frowned upon. Aldermen are not to interfere with municipal civil servants in the implementation of policy nor are the courts to engage in policy formulation. But this strict legalistic approach to the policy process does not mirror political reality; informal operations do take place and are important. These informal operations are of two types; they may involve a proximate policymaker acting outside of his assigned role to influence policy or they may involve a party who is not formally a proximate policymaker taking an active and direct part in decisionmaking. These informal operations may in some cases be even more important than many of the formal operations. Unfortunately for the policy analyst, they are also more difficult to locate and evaluate. But this must be done to achieve a thorough analysis of any policy, perhaps through the hunches and intuitive judgments that form part of what Dror terms the 'extrarational subphases' of policy analysis.

"When a Western political system makes a policy, it is assumed that the policy will be implemented and the results will be somewhere 
17

near those expected." This statement is perhaps less accepted today than it would have been a few years ago; nonetheless it points up one of the differences between developed (Western) and developing policymaking systems. In the latter, the implementation phase is most often the weak link in the policy chain. The reasons are many. One could be cynical and ascribe all shortcomings in implementation to corruption, and it is not to be denied that the mordida can be an important factor. There may also exist a simple shortage of trained, goal-oriented personnel in the bureaucracy, especially in one staffed through patronage. Futhermore, many groups and interests find it more effective and efficient to have policies modified to suit their purposes in the implementation phase than in any other. This is particularly true of groups that may have been denied access to the earlier stages of the policymaking process. In terms used above, informal operations are likely to reach their maximum effectiveness in this stage.

Politically, public response to perceived shortcomings in policy application is somewhat different in developing than in developed nations. Where a public has not been conditioned to expect prompt and efficient policy implementation, the political consequences to a government in the absence of such implementation may be quite minimal. This is especially the case where electoral politics are oriented more toward personality or ideology than toward issues and performance. For all of these reasons this study pays particular attention to the policy implementation stage.

Policy analysis can be pushed both forward and backward from the stages included here. Pushing backward we enter the realm of metapol- 
18

icymaking, policymaking about policymaking. Included here are such aspects as the processing of values, reality, problems and resources, the designing of the policymaking system so as to allocate these, and the determining of a policymaking strategy. This realm will not be explored further; we will take the policymaking system as we find it and work from there. Pushing forward we enter the phases of reaction, evaluation and finally termination. Reaction, the response to the implementation of policy, is examined only to the extent that reaction to a previous, similar policy has become an input into subsequent policymaking or has influenced the political environment. Evaluation of policy comes from two major sources: in-house evaluation by the system that has created the policy, and evaluation unsought but freely offered from the outside, primarily from journalistic and academic sources. The first type of evaluation is not especially prevalent in the particular polities and policy areas under examination here; the second type is one product of this research. The needs of the populace for housing, and governmental response thereto, did not come to an end during the course of this study, nor did the municipalities cease to require additiona1 revenues. The termination phase, then, drops from further consideration.

As Rakoff and Schaefer point out, there is no definitive, broadly 19 accepted term for the end product of the policymaking process. Public policy, policy choices, policy decisions, policy outputs, and policy outcomes are among the terms used. Sharkansky, for examples, chides Dye for failure to differentiate 'policy' from 'outcomes'. Sharkansky himself abjures the term 'outcomes' and speaks of public policy, policy 
outputs and policy impacts as three

important dimensions of the policy process . . public policy represents actions taken by the government; policy output represents the service levels which are affected by these actions; and policy impacts represent the effect which the service has on a population. 20

A good deal of policy analysis literature is devoted to the difference between policy outputs and policy outcomes. There is not always a oneto-one correlation between these. Policies may have final effects very different from those intended. For example, urban freeways were constructed in United States' metropolitan areas, a policy output, to end urban traffic congestion. But the policy outcome has not, in fact, been the end of such congestion. It is not intended in this study to probe deeply into outcomes vis-a-vis outputs but it is worthwhile taking cognizance of the discrepancy, noting with Mr. Dooley that "Results is what you expects, consequences is what you gets."

\section{A MODEL OF THE POLICY PROCESS}

A simple but useful model of the policy process is presented below (Figure 3, page 58). It contains a number of conditions constituting the social, political and economic environments. Individuals may regard these conditions, or some of them, as imperfect and define problems or perceive needs as arising out of these imperfections. If private actions avail nothing and the needs are regarded as too important to ignore, the affected individuals may make demands on the political system for change. (These demands or other anticipated changes may also lead to demands for maintenance of the status quo.)

These demands may be made separately, or several like demands may 


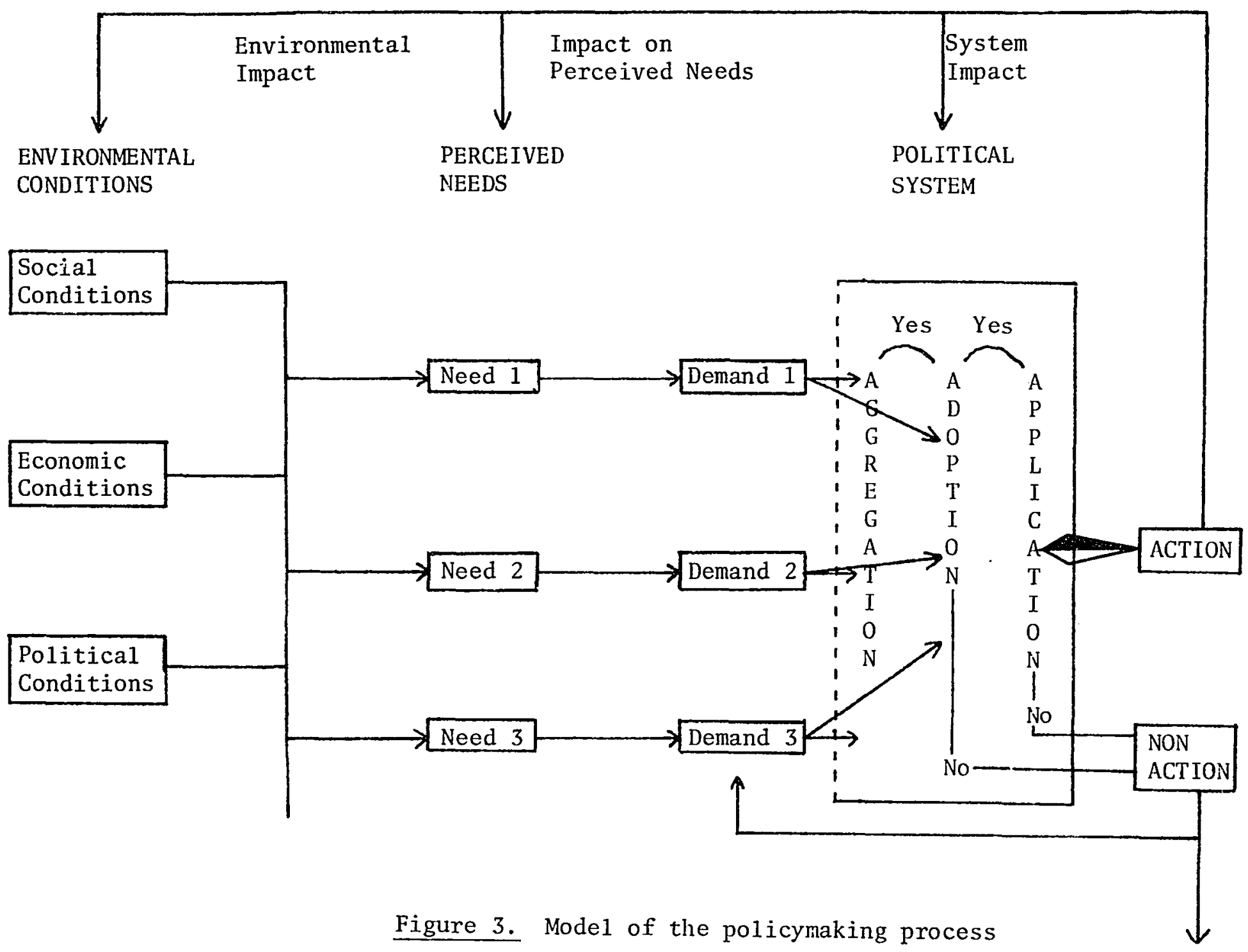


be clustered together. Once inside the political system they may be considered on their own merits, or aggregated. Next, some of these demands are formulated as policy statements and adopted. Of those adopted, some successfully go through the implementation/application phase and ultimately impact upon one or all of the political system, the individual perceived needs or the environment itself. It should be noted that to have effect, policy outputs do not have to reach back as far as the environment.

This model indicates clearly the filtering nature of the political system in the policy process. Each phase may be conceptualized as a screen of successively finer mesh. The mixed bag of demands enters the system. Some are screened out in the aggregation phase. The remainder, either strong enough to stand alone or strategically aggregated with others of their kind pass through to the adoption phase. More are screened out here. Of this select group still others fail to pass through the application phase. The proportion of needs that actually result in some public policy impact is very small.

The genesis of this model in the policy analysis tradition in general and in the work of Rakoff and Schaefer in particular, is documented in the next section. In Chapter I it was pointed out that improving and refining our model is one of the subsidiary concerns of this study. Suggested modifications resulting from empirical testing on our specific policy areas appear in Chapter VIII.

USE OF THE POLICY APPROACH

Implicit in the above description of the policy process and of 
our model thereof are some of the reasons why the policy approach was chosen for this study. These reasons will be more fully explicated here. Policy analysis is more generally applicable than many other research techniques. Of particular importance to this study, it is not disciplinary bound. Nor is it limited in its application to a particular political milieu. Admittedly, as we have shown above, many of the traditional frameworks do have a bias toward developed, Western politican systems but these can be modified to reduce, if not eliminate, this bias.

The policy approach provides a logical framework for longitudinal analysis, enhanced by the consideration of feedback loops. Policy formulation and implementation require time, and during this time actors, roles, demands, and responses cañ change. This approach allows such changes to be taken into account. It also allows for the disaggregation of the decisionmaking process into its component parts for closer examination. It can thus be determined whether some sections are more or less important than others in a particular case, and what relationships exist among them. Moreover, this disaggregation indicates what stages of the process are likely to provide the most effective access to those seeking to influence the policy.

Policy analysis avoids some of the assumptions of the organicfunctional or consensual-homeostatic model and of the developmentalcontinuum model often used in comparative research. ${ }^{21}$ For example it does not posit that any formal interest articulation structures will be found in the polities under comparison. As a result many of the difficulties encountered using those models can also be avoided. This prop- 
erty is likely to prove particularly useful in a study such as this where a number of important informal operations are to be considered. In addition, policy can be measured in many terms, financial and symbolic to mention but two. Or, given the specific foci of this study, it may be expressed in actual construction of housing and raising of revenue.

Finally, policy analysis is singularly appropriate to the scope of this particular dissertation. It is capable of being carried out by a single researcher. It does not require extensive and expensive survey research. Nor does it require a vast array of complex electronic equipment or highly exotic mathematical techniques. When all is said and done the choice of an approach depends to a large extent on the individual researcher's intuition as to what is 1 ikely to work. En fin, the selection of a methodology is a matter of epistemology, as are the criticisms levelled against the selection. And there are fora eminently more suited to epistemological debate than this paper.

THE POLICY ANALYSIS TRADITION

It would be difficult to put an accurate starting date on public policy analysis as an intellectual exercise. In the last decade, however, much literature has appeared attempting to examine the connections between environmental factors such as socioeconomic conditions, the nature of the political system, and public policy. This literature has dealt predominantly with subnational governmental units in the United States; however, its concern with environment-political structure and process-policy linkages makes it relevant to the study at 
hand. A total review of this literature would be both prohibitively time-consuming and inappropriate for our current purposes. Jones, for example, in a recent paper examined only five journals for the period 1963-1972 and found 67 articles classifiable as state and local public 22

policy analysis. Nonetheless this section will look briefly at some of the more important ones in this tradition.

- Most of this literature derives from a 1963 article by Richard Dawson and James Robinson. 23 They attempted to combine economic and political science approaches by considering both political and socioeconomic variables as they related to public policy and by using a comparative rather than a case-study approach. The model of their choice, pictured below, was an adaptation of David Easton's flow model of the political system and the policy process.

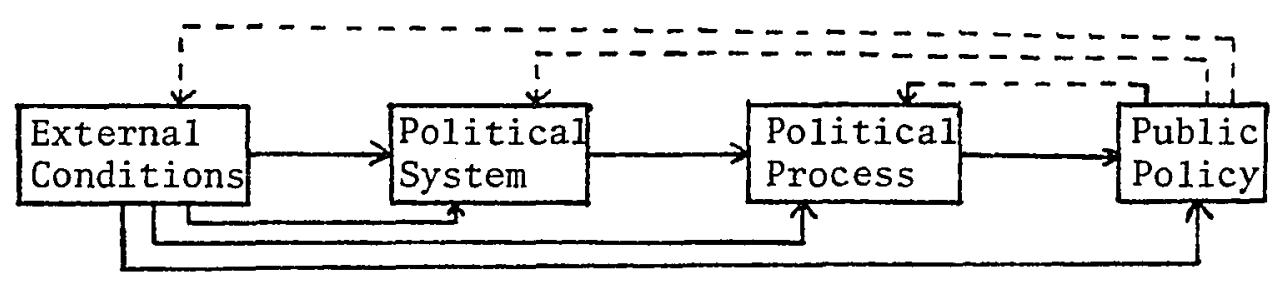

Figure 4. Dawson-Robinson model of the policy process.

Policy, in their view consisted of

the goals (objectives of or commitments made by the political system), the means by which they may be implemented and the consequences of those means . . . the chief output of the political system and the allocation of values for the society - . the outcome of activity or interaction among external conditions, political system and political process. 24

They considered the relationship of a political variable, extent of party competition, and a number of economic factors in determining nine public welfare policies in the American states. 
Much the same approach was taken by Dye. He modified the above model somewhat by collapsing process and system variables into a single category which he called the political system.

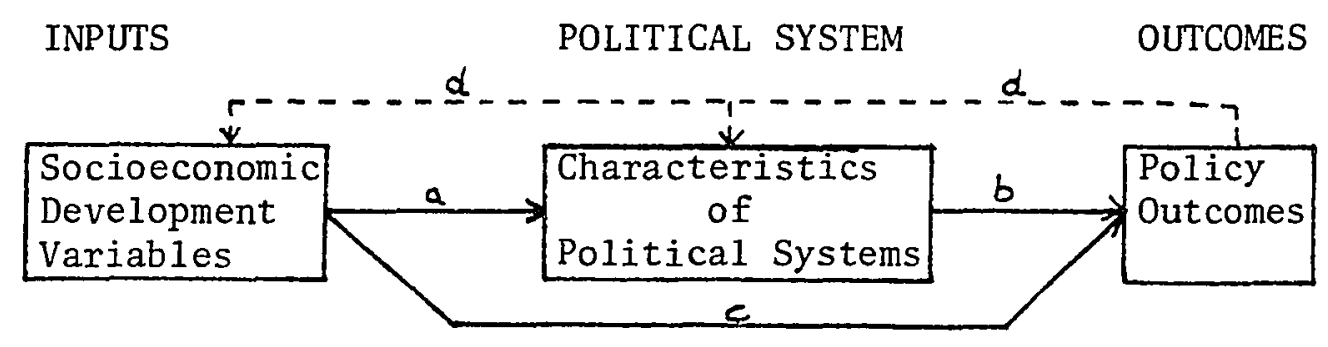

Figure 5. Dye model of the policy process.

In this work he also considered several political factors and dealt with a wide range of state expenditure patterns as the policy outcomes. He concluded that the political system characteristics--division of the two-party vote, level of interparty competition, level of voter participation, and degree of malapportionment--had little independent effect on policy outcomes. He also provided for the possibility that socioeconomic development variables may bypass the political system altogether (c) and be transformed directly into policy outcomes:

Economic development shapes both political systems and policy outcomes, and most of the association that occurs between system characteristics and policy outcomes can be attributed to the influence of economic development. Differences in the policy choices of states with different types of political systems turn out to be largely a product of differing socioeconomic levels, rather than a direct product of political variables. 26

Economic development was measured by levels of urbanization, industrialization, income and education.

Dye's simple model was adopted by most of the policy analysts who followed. No doubt associated with this, their findings continued to 
show an almost preordained policy response to the socioeconomic environment. Lewis Froman in a study at the city level found that certain political structures were associated with 'areal' policies while others were associated with 'segmental' policies, but these structural differences he traced back to the socioeconomic characteristics of 'homogeneous' as opposed to 'heterogeneous' communities. Sharkansky did find, examining groupings of states, that "the regional location of states has a relationship with political characteristics that is inde28

pendent of state economic characteristics" but again this may be regarded as a geographical rather than a political factor. For the most part, however, the social and economic considerations continued to be assigned preeminence over political structure and process in the shaping of public policy outputs.

These findings led Robert Salisbury to be overwhelmed by the possible irrelevance of politics in the American states:

Wealth, urbanization, perhaps settlement patterns, and other such factors account for both political-system characteristics and decisional outputs. . . . This, I submit is a devastating set of findings and cannot be dismissed as not meaning what it plainly says--that analysis of political systems will not explain policy decisions made by those systems. 30

The political system, then, seemed to play no major role in determining the quantity of policy output. At best, it was responsible for incremental changes. If incrementalism was its only function, it would soon be rendered obsolete and immaterial. To avoid this fate, a new job had to be found for the political system. Salisbury developed the model below and posited that the true role of the political system was not to determine amount of policy output but types of policy. In other words, politically-oriented policy analysis could be used to determine the 
situations in which policy would be distributive, redistributive, regulative or self-regulative, depending upon the interactions between

patterns of demand and the structure of the decisional system.

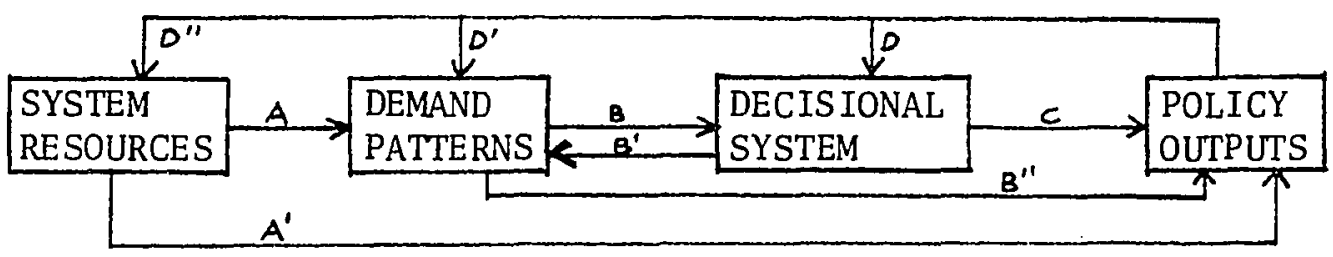

Figure 6. Salisbury model of the policy process.

Interestingly enough he did not address extractive policies, policies designed to obtain the wherewithal for distribution or redistribution.

Not all political scientists and policy analysts agreed with these conclusions as to the reduced importance of political factors in the determination of pubiic policy. Some, perhaps out of self-preservation, argued that these findings were the results of problems in measurement and analysis. ${ }^{32}$ This line of reasoning held that more precision and discrimination in selection of political, economic and social variables and greater sophistication in analysis and in evaluation would surely restore politics to its rightful place at the center of the policymaking stage. The basic assumptions as to the appropriateness of the Dye process model, however, seem not to have been seriously questioned.

In a quantum leap, Rakoff and Schaefer did attack this basic as33 sumption. They maintained that the models of the policy process used were insufficient, the underlying theory was inadequate and the variables, both dependent and independent, were chosen more for their availability than for their policy relevance. Census data were used uncriti- 
cally 'because they were there.' It was these shortcomings, they suggested, that led to the common finding that politics was not very important in determining policy outcomes. It was not that politics was, in fact, unimportant.

They established the following criteria in an attempt to construct a more valid and realistic approach to such studies whose elements included political, social and economic variables:

The theory must specify the relationships between the independent variables and the dependent variable, policy, as well as deal with the relationships among the independent variables. It must possess closure--that is, include among its elements all the variables which might explain the variation in the dependent variable. It must be precise, that is, the elements themselves must be clearly and unambiguously defined. Finally, the model chosen must be appropriate: it must lead us to useful statements of the relationships involved, statements which are empirically verifiable by clear-cut standards. 34

Using these criteria, they concluded that the various adaptations of the Eastonian flow model of the political system and the policy process used by most researchers were not sufficient. They found, agreeing with Sharkansky, that

the conversion of environmental conditions into demands requires the intervention of the attitudes, perceptions, and beliefs of the participants in the system, and also depends upon the operations of both formal and informal means of decisionmaking. 35

In other words, the level of urbanization itself makes no demands on the decisionmaking system. Rakoff and Schaefer also felt that some redefinition of the boundaries of the political system was necessary. The end result of their work was the model shown below (Figure 7, p. 67).

The Rakoff and Schaefer model of the policymaking process, then, represents an improvement over many of the earlier models, although its kinship to them can be recognized. Nonetheless it is not entirely 


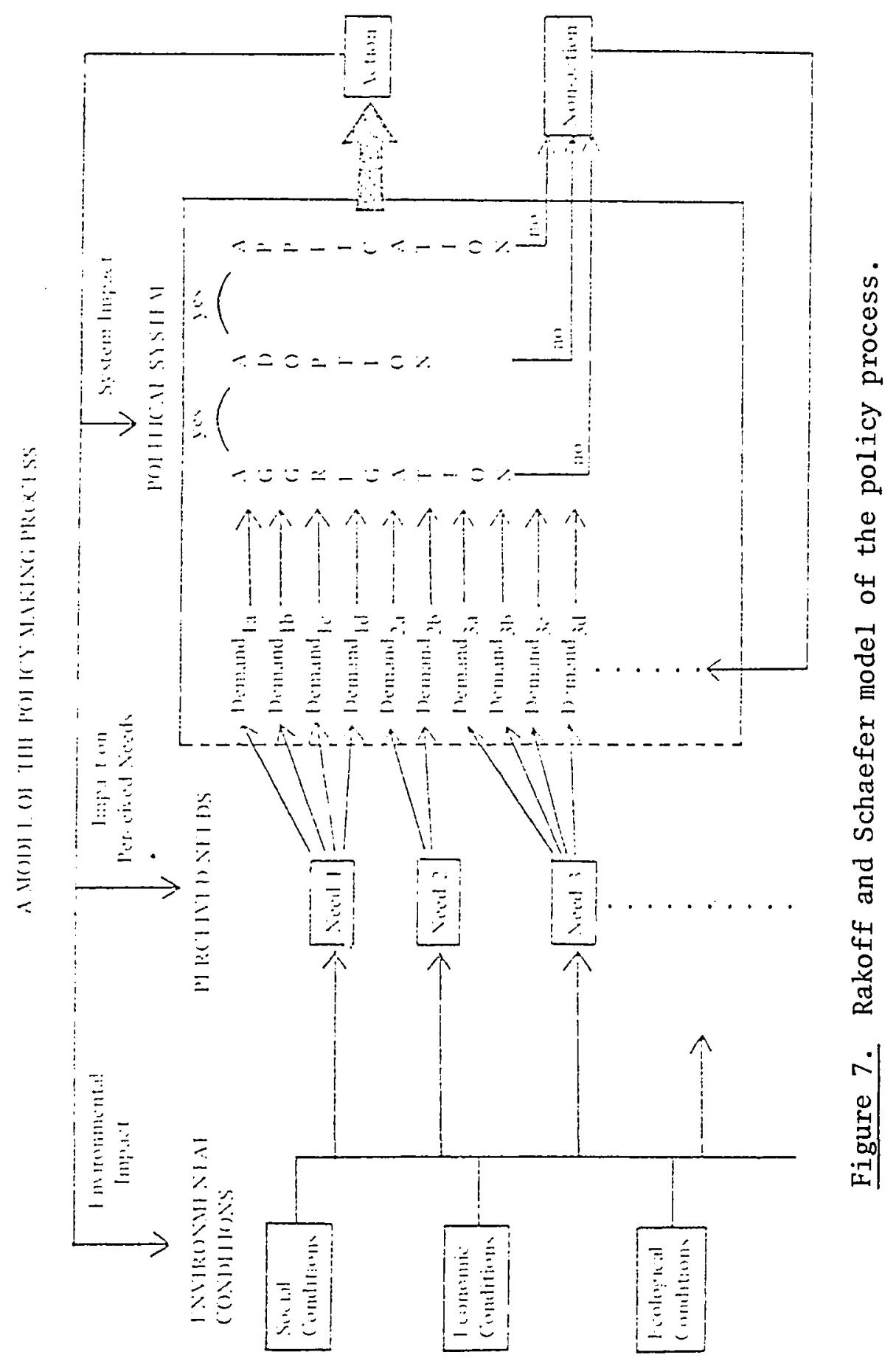


suited in an unmodified form to this study. A number of changes were made to convert this model to our model of choice (Figure 3). Some of these were designed to strengthen the model generally, others are particular adaptations for examining policymaking in developing nations. According to Rakoff and Schaefer, the 'ecological condition' of the environment refers to the "location of rivers and ports and mountains, the occurence of natural disasters such as hurricanes or blizzards, or such contemporary events and conditions as the pollution of 36

atmosphere and water." Ecological conditions, so defined, are not of the same class as economic and social conditions. True, rivers and mountains and ports are not to be ignored but neither do they play any direct role in the policy process. They can affect social or economic factors in the environment and thus be subsumed thereunder. Hurricanes and blizzards are unique events and not ongoing characteristics of the environment. And while policy may be made to replace housing in or provide money to refugees from devastated areas, the policies so made are housing or relief policies, not hurricane or blizzard policies. Pollution, again, we see as acting on and through the social and economic aspects of the environment. For all these reasons our adapted model does not contain the environmental category 'ecological conditions.'

In its place is the category 'political conditions.' It appears that these are insufficiently considered in the Rakoff and Schaefer model. In their model the existing political milieu is vaguely regarded as something through which perceived needs become demands and enter the political system. We contend, however, it is more than this. 
Perceived needs arise from the political conditions of the environment as well as from the social and economic conditions. Moreover, the political environment is also the result of a series of policy outcomes from the decisionmaking system. And certain important considerations such as the condition of political dependence found in developing nations are most appropriately included here. In summary, the boxes labeled 'social,' 'economic,' and 'political' conditions will be filled with the appropriate elements, listed above on page 11 .

In earlier discussion of the policy process it was indicated that one of the truly difficult conceptual problems was dealing with boundary conditions and this problem arises again here. At what point do perceived needs become demands? The Rakoff and Schaefer model assumes that the political system is faced with needs and that these needs are are translated into demands either at the system boundary or within the system. It is our contention, however, that needs are most often converted into demands outside the political system and it is demands that the political system encounters. In any event, policymaking is a process, not merely a series of discrete actions, so the emphasis of policy analysis must be on the linkages, and boundaries are to be treated as interfaces, not as blockades.

The usual frameworks for policy analysis assume that needs are perceived and problems identified outside of the political system. If this is the case in developed policymaking systems, a debatable proposition, it is certainly not the universal situation in developing nations. It was suggested earlier that the governments, national and subnational, in Costa Rica and El Salvador may well play the role of 
patron. In this case, the needs would be perceived and the problems identified almost completely within the political system. This is not to suggest that adoption and application of policy would thus become automatic and analysis of decisionmaking trivial, but it would affect the shape of the policy process.

For one thing, the aggregation phase could assume less importance than it is customarily assigned. This would be the case particularly where political parties were primarily ideological and/or personalistic in nature and were not brokerage agencies as the United States' political parties are often regarded. As a result, nonaggregation of demands would not necessarily disqualify these from further consideration in the formulation-adoption stage.

One final modification of the Rakoff-Schaefer model seemed desirable to adapt it for this particular study. In their model, incipient policies that are aborted in the aggregation, adoption or application phases, re-enter the political system as demands. This may or may not be the case; we must be prepared to accept the possibility that such potential policies, not acted upon, might simply fall into policymaking limbo.

Our debts to Rakoff and Schaefer in particular and to the earlier policy analysts in general are nonetheless considerable. Hopefully, our model, as tested in the field and suitably modified, will be another incremental step in the development of a nonculturebound framework for policy analysis, applicable in the developing as well as in the developed countries. 
THE COMPARATIVE APPROACH

One integrative stream can be found running through all of the studies cited above. This is the comparative approach. The diverse authors have made broad and all-compassing statements on the desirability of comparison in public policy analysis. Dye, for example, maintains that

the development of an explanatory model of public policy, whether in international politics or American state politics, requires comparative analysis. Comparative analysis occupies a distinguished place in all political inquiry. 37

Froman states flatly, "If we are to develop theory in the public policy field, comparative research is needed." Nonetheless, we feel it is useful here to iterate the case for comparative analysis both in general and for this essay in particular.

Perhaps the primary reason for comparing is that at the moment there exists no absolute standard of performance by which to measure or evaluate a policymaking system; a result, perhaps, of insufficient metapolicymaking. We must, then, satisfice, go to second best and measure systems by comparing them one against the other. It might be possible, knowing the inputs into two political systems to calculate net policy outputs and examine the relative efficiencies of the two systems. Dror includes comparative surveys as important means of examining know alternatives, one of his rational subphases of the preparation of major 39 alternatives phase.

A second important reason for comparing is to distinguish a common class of urban phenomena. One end of all research is the discovery of empirical generalizations that can be verified and eventually become 
part of an overall explanatory structure. It is possible in a comparative study to approach the ceteris paribus by choosing subjects of study in such a manner that the appropriate number of variables are held constant. Of course care must be taken to ensure that the ceteris does not become so paribus as to render the results trivial.

Comparative research may show that certain variables tend to occur in association, knowledge that could have some explanatory or predictive value. In fact, we seek covariation among variables with as much scope of verification as possible. The usual three caveats must be observed: assure that the relationship discovered is not spurious, remember that statistical association is only an identity and not an explanation, and avoid tautologies.

Harold Lasswell has pointed out that the development of political science has been hindered by a tendency to view the political process in each territorial unit as unique. We maintain here, following william Hanna, that the comparative method can lead to the dissolution of these separate frames of reference, providing opportunities to "extend generalizations, specify conditions, develop new hypotheses and enlighten specific cases." In short, then, comparative research is undertaken to find explanations for urban phenomena and to separate common from particular explicans.

The comparative method is applicable to policy analysis in general and to urban research in general. Again, it is not disciplinary bound. Further, it is singularly appropriate to the study of the policy process in developing nations. Smith lists four reasons why this is so. First, tists expect to evaluate public policies or to offer advice to 
policymakers. Second, the examination of non-Western policy processes can provide insights regarding neglected aspects of the policy process in Western nations. Third, while it is useful to study policy in terms of "outputs" in Western countries (often operationalized in public expenditure figures) such an endeavor in nany developing countries may result in misleading explanations. Last, the literature of comparative politics and comparative administration is a fruitful source of insights, concepts, and models of policy processes. 42

In Chapter VI our model and the comparative approach are used in an examination of the actual policymaking process in San Salvador and San José. Chapter VIII presents the conclusions reached as a result of this examination, and the modifications suggested as useful by our empirical testing. 
CHAPTER III NOTES

1. Ira Sharkansky, "The Political Scientist and Policy Analysis," in Ira Sharkansky, ed., Policy Analysis in Political Science (Chicago: Markham Publishing Co., 1970), p. 1 .

2. Stuart H. Rakoff and Guenther F. Schaefer, "Politics, Policy and Political Science: Theoretical Alternatives," Politics and Society 1 (1970):69.

3. Ibid., p. 70 .

4. Thomas R. Dye, Understanding Public Policy (Englewood Cliffs, N.J.: Prentice-Ha11, Inc., 1972).

5. David Easton, A Framework for Political Analysis (Englewood Cliffs, N.J., : Prentice-Hal1, Inc., 1965).

6. John Dewey, The Public and Its Problems (Chicago: Swallow Press, Inc., 1954), p. 18 .

7. Daniel Elazar, "The States and the Political Settings," in Sharkansky, Policy Analysis, p. 73.

8. Easton, Political Analysis, p. 66.

9. Charles 0. Jones, An Introduction to the Study of Public Policy (Belmont, California: Wadsworth Publishing Company, Inc., 1970).

10. Rakoff and Schaefer, "Politics, Policy, Political Science."

11. William Riker, A Theory of Political Coalitions (New Haven: Yale University Press, 1962).

12. Thomas R. Smith, "The Study of Policymaking in Developing Nations," Policy Studies Journal 1 (1973): 245 .

13. Yehezke1 Dror, Public Policy-Making Re-examined (San Francisco: Chandler, 1968).

14. Herbert A. Simon, "A Behavioral Model of Rational Choice," Quarterly Journal of Economics 69 (1955):129-138.

15. See Anthony Downs, An Economic Theory of Democracy (New York: Harper and Row, 1957).

16. Dror, Public Policy-Making. 
17. Smith, "Developing Nations," p. 246.

18. Terminology from Dror, Public Policy-Making.

19. Rakoff and Schaefer, "Politics, Policy, Political Science," p. 68.

20. Sharkansky, "Environment, Policy, Output and Impact: Problems of Theory and Method in the Analysis of Public Policy," in Sharkansky, Policy Analysis, p. 63.

21. Categories taken from Gerald Jordan, "Three Models of Political and Social Change," Administrative Law Review 22 (1970):117-132.

22. Charles 0. Jones, "State and Local Policy Analysis: A Review of Progress," in American Political Science Association, Political Science and Local Government (Washington, D.C.: American Political Science Association, 1973), pp. 27-54.

23. Richard E. Dawson and James A. Robinson, "Inter-Party Competition, Economic Variables and Welfare Politics in the American States," Journal of Politics 25 (1963):265-289.

24. Ibid., p. 267.

25. Dye, Politics, Economics and the Public: Policy Outcomes in the American States (Chicago: Rand McNally and Company, 1966).

26. Ibid., p. 293.

27. Lewis A. Froman, Ir., "An Analysis of Public Policies in Cities," Journal of Politics 29 (1967):94-108.

28. Sharkansky, "Economic Development, Regionalism and State Political Systems," Midwest Journal of Political Science 12 (1968):60.

29. Among the more important works in this genre are Sharkansky, Spending in the American States (Chicago: Rand McNally and Ecompany, 1968), and The Politics of Taxing and Spending (Indianapolis: Bobbs-Merri11, 1970); and Richard Hofferbert, "Socio-Economic Dimensions of the American States," Midwest Journal of Political Science 12 (1968):401-418, and "The Relation Between Public Policy and Some Structural and Environmental Variables in the American States," American Political Science Review 60 (1966):73-82. The best bibliographies are to be found in Sharkansky, Policy Analysis and Jones, "State and Local Public Policy Analysis."

30. Robert H. Salisbury, "The Analysis of Public Policy: A Search for Theories and Roles," in Austin Ranney, ed., Political Science and Public Policy (Chicago: Markham Publishing Company, 1968), pp. 151175 .

31. The typology of public policy is a study in itself and is not be be 
considered further in this essay. Salisbury's typology is an expansion of Theodore Lowi's work in his seminal, "American Business, Public Policy, Case-Studies, and Political Theory," World Politics 16 (1964):27-44. More complex examples yet may be found in Froman, "The Categorization of Policy Contents," in Ranney, Political Science, pp. 41-52, and Jones, "State and Local Public Policy Analysis."

32. See, for example, Herbert Jacob and Michael Lipsky, "Outputs, Structure and Power: An Assessment of Change in the Study of State and Local Politics," Journal of Politics 30 (1968):510-538; also James W. Clark, "Environment, Process and Policy: A Reconsideration," American Political Science Review 63 (1969):1172-1182.

33. Rakoff and Schaefer, "Politics, Policy, Political Science," pp. 5177 .

34. Ibid., p. 54 .

35. Ibid., p. 56 .

36. Ibid., p. 62 .

37. Dye, "A Mode1 for the Analysis of Policy Outcomes," in Sharkansky, Policy Analysis, p. 29.

38. Froman, "The Categorization of Policy Contents," p. 52.

39. Dror, Public Policy-Making, p. 316.

40. Harold D. Lasswell, Foreword to The Rulers and the Ruled, by Robert E. Agger, Daniel Goldrich, and Bert E. Swanson, (New York: John Wiley \& Sons, Inc., 1964), p. v.

41. William John Hanna, "Comparative Urban Politics," Journal of Comparative Administration 4 (1972):271.

42. Smith, "Policymaking in Developing Nations," p. 248. 
CHAPTER IV

POLICY AREAS

Chapter I indicated the particular policy areas examined in this paper are municipal revenue and public provision of low-cost housing. It is important to choose areas of substantive value for the analysis. As Cliff Kaufman has pointed out, policy relevance is a necessary if not sufficient consideration in the determination of research priori1 ties.

One set of reasons, then, for the choice of these areas, lies in their intrinsic importance.

The other set of reasons is procedural; a great deal of information is available on public finance and public housing. The policy outputs may be determined, making it possible to go back and trace the process through which these outputs were generated. Moreover, there exists a set of generally accepted principles against which the actual policies of San José and San Salvador are analyzed.

This chapter treats these two policy fields, urban finance and public housing. Each will be examined from the viewpoints of their importance to the community and their basic principles. The specific processes that lead to their formation will be considered in Chapter VI and the results of these processes in Chapter VII. We look first at urban finance and later at public housing. 
MUNICIPAL REVENUE RAISING

Public finance may in some ways be regarded as the single most important policy area, for without funds most other policy decisions made by a municipal or other government agency may well be rendered moot.

Rudolf Goldschied regarded the field of public finance as so important that he suggested the development of an entirely new science of 'Fiscal Sociology' to "examine the impact of revenue raising as well as spending policies to the total society in its internal and external relationships." He went so far as to argue that "public finances represent the driving motor of the total societal development." And the two faces of the Janus of public finance were not to be considered as separate entities:

Tell me how and whence you acquire your revenue and I shall tell you what your expenditure budget must look like. The same applies in reverse: Tell me what you want to spend your money on, and I shall tell you by what means you will get the required revenue, what class of society you must draw upon and the size and kind of administrative apparatus you will need therefore. ${ }^{2}$

Budgets, then, are not only accounting ledgers of income and expenses but are also overall indicators of policy responses and provide insights as to the general mindsets of the agencies preparing them. This holds just as true for urban areas of Latin America as for the general case. Further, in the case of comparative urban studies in Latin America, "Research on the causes and consequences of urban growth has focused on demographic, sociological, and physical aspects of the topic far more than on economic and political dimensions." ${ }^{3}$ Public finance, manifestly, contains both economic and political dimensions, 
and a study such as this should serve as one small particle in filling the research hiatus suggested above.

Pragmatically, public finance as a policy field lends itself to the researcher's needs. Even in jurisdictions with rather primitive data gathering and handling procedures, government revenues and expenditures, by class, are among the first data to be quantified and tabulated and made more or less readily accessible to the public. Moreover, there exists a corpus of public finance, or at least revenue raising, theory as to what are the 'right' ways to go about raising money in certain places at certain times for certain purposes. Such theory suggests, for example, where taxes are to be preferred to user charges. Comparisons of the public finance policies of the two polities can be more meaningfully made against such a background.

It is appropriate at this point to describe briefly the principles of public finance and more specifically, of tax policy. Following this some particularly urban applications will be examined along with some considerations of taxes vis-a-vis user charges. Finally, we will look at the developmental paradigm of Luiz de Moraes, a model designed especially for municipal finances in Latin America. It is this model that will serve as our norm in the light of which the revenue systems of San José and San Salvador will be compared.

There exists, at least at some level of generalization, agreement as the the bases of taxation of practical postulates of tax policy. The outline below was suggested by Wagner some 90 years ago, but remains a useful general statement as to what 'good' taxation should involve. Each of the nine criteria will be commented upon 
briefly. In considering these it must be remembered that the choice of tax or other revenue policy is ultimately a political choice.

A. Financial Principles:

1. Adequacy of yield.

2. Flexibility of taxation.

B. Economic principles:

3. Choice of correct sources of taxation, i.e., especially examination of the question whether taxes should be levied on individual and national income only or also on individual and national wealth (capital), and whether and how far a distinction must be made between the interests of the individual and the national economy.

4. Choice of the kind of tax, in the light of the effect of taxation and of different kinds of taxes on the taxpayers, and general examination of the problem of tax shifting.

C. Principles of justice, or of the equitable distribution of taxation:

5. Universality, and

6. Equality of taxation.

D. Principles of tax administration (or principles of the administrative efficiency of the tax system:

7. Determinacy of taxation.

8. Convenience.

9. Effort to ensure the lowest possible collection costs. 5

The first principle, adequacy of yield, requires little explanation. There is no point in levying a tax if it is not going to bring in sufficient revenue to justify itself. This principle is, unfortunately, widely violated in certain jurisdictions that attempt to regulate morality by taxing such commodities as tobacco, liquor and commer6

cial sex. Insofar as these taxes are designed to raise revenue, they are legitimate. Insofar as they are designed to uplift morals, they are illegitimate. This latter activity may be an appropriate role for churches and ministeries of culture, but not for tax policy.

A good tax must also be flexible. It should be designed so as 
to increase quickly when necessary, and to be lowered or discontinued when the needs for revenue decrease or are better met from some other source. Income taxes are relatively flexible taxes; as income rises so do taxes therefrom, and rates are relatively easily changed by the appropriate legislative bodies. Examples of inflexible taxes are fixed amount head or poll taxes.

The choice of correct sources of taxation is very important, and regrettably, seems to receive insufficient consideration in many jurisdictions. The question of whether income only should be taxed, or also capital, is only one of these issues. It can be argued that if income as return to capital is taxed, capital should not be taxed. Capital diminished by taxation cannot generate as much income, hence, not as much income tax. It must also be remembered that whatever the ostensible tax base, income and capital are the only sources of taxes. Property taxes are not paid in land nor mining taxes with ore; all taxes are paid with money and money comes from capital or income.

The kinds of taxes selected should also take into account effects other than just revenue raising. Will a capital gains tax, for example, discourage investment in the economy, with a consequent loss of current or potential jobs, hurting not only the individuals involved but perhaps jeopardizing future income tax revenue? Tax policy need also be formulated in such a way as to ensure, as far as possible, that those upon whom the tax is levied actually pay it. If a payroll tax is imposed on an employer for example, how much of the cost does the employer actually absorb, how much is shifted forward to his customers, and how much is shifted backward onto his employees? An additional con- 
sideration, in the case of export taxes, is whether or not the ultimate tax burden can be shifted totally out of the country.

Justice in taxation involves considerations of universality and equality. Today the terms horizontal and vertical equity are commonly used, and it is worthwhile to consider these concepts in somewhat more 7

detail. Of these, horizontal equity is the clearer and more unambiguous. Once the criteria for equality are chosen, all individuals equal in these criteria should pay equal taxes. The problem lies in the choice of criteria. In the realm of personal income for example, should income itself be chosen, or is consumption expenditure more equitable? And how is income, including nonmonetary income, to be defined? Although the principle is precise, the difficulties in operationalizing it are legion.

Horizontal equity, then, demands that equals be taxed equally. Its corollary, vertical equity, calls for unequals to be treated unequally. But how unequally are they to be treated? Should the wealthier, however defined, pay the same proportion of their income in taxes as the poor, with their greater dollar sacrifice regarded as sufficient inequality? Or should those with higher incomes also pay a higher proportion of their income in taxes? Some of the arguments for this latter viewpoint have been presented above in the discussion of the diminishing marginal utility of money.

Some economists cite the principle of vertical equity as the ability-to-pay approach. Musgrave has identified three schools of 8 thought in this genre. In the first of these, the expenditure side of the budget is ignored and only the tax burden is considered. The 
state is to impose tax shares in an equitable manner. The nature of this equity is to be determined by non-economic, non-political factors. A wide variety of viewpoints is thus encompassed in this school; the specific concept of equity depending on the ethical, philosophical, and/or religious proclivities of the individual advocate. The second school, of which John Stuart Mill is the leading spokesman, also ignores the expenditure side. Here the distribution of the tax burden is a matter of welfare economics. The burden is to be distributed so as to minimize total societal sacrifice and this can be achieved only by taxing each taxpayer up to the point where the marginal sacrifices of all taxpayers are equal. The third view kept the welfare approach in determining tax shares but expanded the argument to include the expenditure side of the budget: "Thus the budget came to be seen as a more or less general plan to maximize welfare." Under this third view, it was possible to increase the tax share of the poor and still maintain vertical equity on the grounds that if the poor benefited disproportionately from public sector expenditures, it was equitable to ask them to pay more.

It may be argued, of policies in general as well as tax policies in particular, that no policy can be better than its administration. One of the factors to be considered is determinacy of yield. An inheritance tax in a jurisdiction composed of a few large, wealthy landholdings, where the oldest child by law inherited the family estate, might well, in a 50-year averaging period, yield adequate revenues but there would be no guarantee that in any one-year period the government would have sufficient funds to operate. An income tax, however, with 
monthly or weekly withholding provisions, would yield a determined amount of revenue.

Convenience is a two-sided coin. On the one face there is the matter of convenience to the taxpayer. A tax payable a little each payday is for most taxpayers more convenient than one to be paid in a lump sum once each year. Convenience to the tax collector means the minimum effort exerted for each dollar in revenue obtained. The property tax, which requires the taxing unit to assess and reassess and maintain extensive and elaborate records, and which the taxpayer must pay in a lump sum once each year an amount generally unknown until the bill arrives, is about as inconvenient a tax as one could devise.

Finally, the taxing unit wishes to obtain its revenue at the lowest possible cost. A tax in which cost of collection is a large percentage of the yield is to be avoided. The most common way of minimizing tax collection costs is to pass them on to someone else. This is part of the reason why income and payroll taxes, in which the employer has to do the bookkeeping, and sales taxes, where the merchant absorbs the collection costs, are so attractive to tax administrators.

In examining the above principles of taxation as a whole, two apparently dichotomous strains can be determined. In one, a certain mutuality can be found. Some of these principles fit naturally together; one implies the other. But in different cases, two or more of the principles seem to be almost mutually exclusive. It is unlikely that a single tax or tax system scoring high on each of these principles can be devised. At least, however, it should be possible to design tax policy that violates as few of them as possible. Again, tradeoffs need 
be made and for all the guidance of economic principles, the determination of tax policy is in the final analysis a matter of politics.

The tax and revenue principles discussed above apply to all

levels of government. Each level, however, has specific considerations of its own. Discussed below are some of the considerations that are particular to local government. Urban jurisdictions have three special pecularities that need be taken into account: first, the presence of spillover effects; second, the need for an appropriate mix of taxes and user charges for local services; and third, the existence of 1 egal and political restraints on local revenue raising.

In most urban areas there are a number of services providing benefits to non-residents of the local government jurisdiction. These beneficiaries consume these services at no cost to themselves but at the expense of the taxpaying resident. Consequently the residents are often, reasonably, unwilling to tax themselves heavily to provide these services. As a result, adequate levels of these services are often not provided.

One strategy commonly adopted in the attempt to internalize these externalities is the areal expansion of the urban government jurisdiction to make it, as far as possible, coincident with the area in which the services it provides are enjoyed. It can readily be seen, however, that there are finite limits on the extent to which this can be done. Another possible solution is to shift the cost of financing these particular services to a higher level of government whose jurisdiction contains all the beneficiaries. This solution is seldom attractive to the level of government expected to absorb these costs. Moreover, the 
lower level of government is more often than not reluctant to transfer any of its functions, as opposed to the costs, to the higher 1evel. A third possibility is the financing of the specific services involved through user charges rather than taxes. If this is done, there is far less likelihood of a serious undersupply.

The benefit principle, then, is the basic philosophical underpinning for user charges, just as the ability-to-pay principle, discussed above, forms the basis of much of the decisionmaking process in the realm of taxation. The questions are often raised as to why a government should engage in supplying anything but those public goods whose free provision benefits the society in general, and why might governments take part in various quasi-business activities designed to serve a myriad of special ends. One answer has been suggested above. Another is that many of these goods are not pure public goods but quasipublic goods. The exclusion principle still holds, at least in part. This being the case, it is appropriate for a government to levy some kind of charge rather than paying for the good completely out of general tax revenue.

It has been suggested by the Tax Foundation that

four major reasons underlie government provision of goods and services for a fee. These are: (1) the expectation of undesirable by-products if produced privately; (2) low profitability of the enterprise; (3) cost advantages related to joint products, one of which must be government provided; (4) tradition or historical accident. 11

The nature of urban governments is such that more of the services they provide fit these categories than is the case with national governments. Consequently, user charges play a more important role in municipal finances than in national finances. In the United States, for example, 
about 15 percent of local government revenue is derived from user charges while the federal government receives some two percent of its 12

revenue from this source. It will be shown that this difference is not as great in the Central American countries where the national governments provide many of the chargeable services rendered by local governments in Anglo America.

A brief listing of some of the commonly provided urban services indicates their amenability to user charges. Among these are urban mass transit, water, sewage, on-street parking, hospitals, bridges and tunnels, garbage pick-up, public housing rental, operation of sanitary landfills, and vector control. A major difficulty with these is determining the proper rate of charge and the proportion of service cost to be user-charged rather than financed out of general tax revenue. The general view is that user charges need not cover the entire cost of the service provided, that a partial subsidy from general tax revenues is appropriate. Some economists, however, hold that if user charges are to be applied they should pay the entire cost of the service. Alan Prest, speaking specifically of developing nations such as Costa Rica and E1 Salvador, maintains the user charges must cover all current operating costs, appropriate depreciation allowances (a replacement value basis for renewable assets, an alternative use value for non-renewable assets), a contribution towards capital costs of expansion and a contribution towards the costs of public overhead expenditures.13

In addition to the problems attendant upon revenue raising per se, municipalities must also deal with legal and political restrictions, to which higher levels of government are not subject. Municipal governments, wherever found, are creatures of superior governments and 
have only such freedom in revenue raising as these superior governments are prepared to grant. In practice this generally means that the most lucrative sources, income and excise taxes for example, are appropriated by national or state governments, leaving the municipalities only such purely local sources as property taxes and user charges on urban services. Moreover, the higher level of government often places formal limits on the amount of the local levy or requires that any change in rate or new charge or tax be submitted for its approval before going into effect.

The second major set of restrictions on local government revenue raising is political rather than legal. In many jurisdictions certain sets of revenue measures are submitted to the electorate for its direct approval in plebiscites or referenda. The governing body then must not only decide on a revenue policy but also sell it to the voters. And experience has shown that electors often adopt some criterion other than general societal welfare when voting on money matters. Even if not consulted directly on revenue measures, voters often express their opinions, usually negative, when those officials who have introduced these measures seek reelection. Local government officials are far more vulnerable in this respect than those at higher levels. It has been suggested, in fact, that city councilmen are often voted out of office in a form of indirect protest against, or at least frustration with, tax increases at higher levels of government. Municipal officials, particularly those with aspirations to higher office, may be understandably reluctant to adopt revenue policies calling for higher taxes or user charges even when they are convinced that such increases 
would be in the city's best interests.

Finally, municipal revenue raising in Latin America, where the municipalities are even weaker than in Anglo America, has some characteristics and problems of its own. De Moraes lists some of these: the patrimonial base of much of the municipal levy, the determination of many rates ad speciem rather than ad valorem, and a revenue raising system based generally on medieval criteria.

In the majority of cases there is no direct relationship with a justified base for taxation and the only important argument in favor of maintaining [this system] is that it produces income (albeit in insufficient amounts). 14

He sees the consequences of this as "a static economy, deficient public services and a strong tendency to centralization" and suggests an overall long-run scheme for improvement. This plan is summarized in Figures 8 and 9, pages 90 and 91. Chapter VII below will detail the extent to which his criticisms are accurate with respect to San José and San Salvador, and indicate the extent to which progress is being made toward fulfillment of his developmental paradigm.

As shown in Figure 8, de Moraes suggests that municipal tax systems can also evolve from the current systems, which he characterizes as medieval, to a future system in which the economy is fully understood and the tax system can be fine tuned to both generate adequate revenue and encourage economic development. In actuality, individual municipal tax systems are more likely to be located somewhere along a continuum than contained totally within one of his three boxes. We see, for example, tax systems using both ad valorem and ad speciem impositions. We will however, determine which of his models San José and San Salvador most closely resemble. 


\begin{tabular}{|c|c|c|c|}
\hline System & Base & Characteristics & Consequences \\
\hline Current & Patrimonial & $\begin{array}{l}\text { Utilization of patrimonial natural } \\
\text { resources } \\
\text { Taxes and charges based on things } \\
\text { and persons } \\
\text { Imposition ad speciem }\end{array}$ & $\begin{array}{l}\text { Static economy } \\
\text { Deficient services } \\
\text { Tendency to centralization }\end{array}$ \\
\hline Transitional & Financial & $\begin{array}{l}\text { Prevalence of taxes and user } \\
\text { charges } \\
\text { Income according to the concepts } \\
\text { of increased rates and } \\
\text { earmarking } \\
\text { Some cases of double imposition } \\
\text { Imposition ad valorem }\end{array}$ & $\begin{array}{l}\text { Augmentation of financial } \\
\text { capacity } \\
\text { Improvement of service delivery } \\
\text { Tendency to decentralization }\end{array}$ \\
\hline Future & Economic & $\begin{array}{c}\text { Adequate levy on existing eco- } \\
\text { nomic bases } \\
\text { Perfect distinction between } \\
\text { charges and prices } \\
\text { Utilization of extrafiscal } \\
\text { aspects of taxation }\end{array}$ & $\begin{array}{l}\text { Dynamic economy } \\
\text { Establishment of developmental } \\
\quad \text { fiscal policies } \\
\text { Tendency of cooperation }\end{array}$ \\
\hline
\end{tabular}

Figure 8. Evolutionary model of the municipal tax system, from de Moraes, "En Busca de una Teoria," p. 123. 


\begin{tabular}{|c|c|c|c|c|c|c|}
\hline Al ternative & $\begin{array}{l}\text { Financial } \\
\text { Mun. Gov't }\end{array}$ & $\begin{array}{l}\text { fects } \\
\text { Nat. Gov't }\end{array}$ & $\begin{array}{l}\text { Administrative } \\
\text { Cost }\end{array}$ & $\begin{array}{l}\text { Increase in } \\
\text { Income }\end{array}$ & $\begin{array}{l}\text { Additional } \\
\text { lixigencies }\end{array}$ & $\begin{array}{l}\text { Economic } \\
\text { Focus }\end{array}$ \\
\hline $\begin{array}{l}\text { Creation of } \\
\text { new taxes }\end{array}$ & Gains & -- & Increase & \multirow{3}{*}{$\begin{array}{l}\text { Depends on } \\
\text { the } \\
\text { municipal- } \\
\text { ity's own } \\
\text { effort }\end{array}$} & \multirow{6}{*}{$\begin{array}{l}\text { Increase in } \\
\text { calculation } \\
\text { and } \\
\text { collection } \\
\text { activity }\end{array}$} & \multirow{6}{*}{$\begin{array}{l}\text { Income } \\
\text { generated } \\
\text { in the } \\
\text { municipal } \\
\text { territory }\end{array}$} \\
\hline $\begin{array}{l}\text { Transfer of } \\
\text { taxing capacity }\end{array}$ & Gains & Loses & --- & & & \\
\hline $\begin{array}{l}\text { Additions to } \\
\text { municipal taxes }\end{array}$ & Gains & --- & Increase & & & \\
\hline $\begin{array}{l}\text { Addition to } \\
\text { national taxes }\end{array}$ & Gains & -- & Increase & \multirow{3}{*}{$\begin{array}{l}\text { Does not } \\
\text { depend on } \\
\text { the } \\
\text { municipal- } \\
\text { ity's own } \\
\text { effort }\end{array}$} & & \\
\hline $\begin{array}{l}\text { Transfer of the } \\
\text { total collection } \\
\text { of national taxes }\end{array}$ & Gains & Loses & -- & & & \\
\hline $\begin{array}{l}\text { Transfer of } \\
\text { partial collection } \\
\text { of national taxes }\end{array}$ & Increases & Diminishes & --- & & & \\
\hline Special subsidies & Increases & Diminishes & -- & $\begin{array}{l}\text { Depends on } \\
\text { criteria } \\
\text { for dis- } \\
\text { tribution }\end{array}$ & $\begin{array}{l}\text { Elaboration of plans of } \\
\text { application and verifi- } \\
\text { cation of expenses }\end{array}$ & $\begin{array}{l}\text { Redistri- } \\
\text { but ion of } \\
\text { income }\end{array}$ \\
\hline
\end{tabular}

Figure 9. Analysis of alternatives, from de Moraes, "En Busca de una Tcoria," p. 127. 
Figure 9 suggests some alternative strategies for modifying tax systems, and the likely financial effects of these on various levels of government. De Moraes shows an appreciation for the redistribution of costs and benefits--and the actual increase, in some cases, of costs. His alternatives do not--as in fact his theory generally does not-consider the political nature of the tax structure. Nonetheless, it is the best, and only, effort of its kind undertaken to date and will be used as a standard against which to evaluate the tax systems of San Salvador and San Jose.

PUBLIC HOUSING

As was the case with revenue, public housing policy is both important qua policy and an intriguing if complex field of investigation for the policy analyst. The housing shortage, it is said, is no more than an ugly rumor circulated by people who have no place to live. Joseph Fried, however, has stated:

So far as the housing situation in the developing countries of Asia, Africa and Latin America is concerned, the only word that can possibly describe it is catastrophic. 15

Various figures are given to supply a quantitative dimension to this catastrophe. A number of these will be considered below but as one example Marcia Keith and colleagues calculated the minimum number of new dwellings that would need to be built in 1975 alone as 19,360 in Costa Rica and 35,991 in E1 Salvador. Of these 11,334 of the Costa Rican units and 24,825 of the Salvadorean would be required in urban 16 areas.

The most visible evidence of the housing crisis in Latin America, 
and in most of the developing world, is the existence of shanty towns or squatter settlements on the margins of the larger cities, or on va17

cant land within them. Inhabitants have constructed makeshift shel-

ters of plywood, cardboard, flattened tin cans and oil drums and any-

thing else they have been able to assemble. These settlements may reach

considerable size; over 1,000,000 people are said to inhabit home-made

shantytowns on the outskirts of Calcutta and more than 600,000 squatters occupy the barriadas of Lima.

These squatters, mainly recent migrants, have exhibited a surprising degree of organizational skill in their construction of their colonies. Alan Paton gives this account of the process of creating a shantytown in Capetown from the squatters' viewpoint.

-Do you hear what Dubula says? That we must put up our own houses here in Orlando?

-And where do we put up the houses?

-On the open ground by the railway line, Dubula says.

-And of what do we build the houses?

-Anything you can find. Sacks and planks and grass from the veldt and poles from the plantations.

-And when it rains?

-Siyafa. Then we die.

There is the open ground by the railway line, but what of the rain and the winter? They say we must go there, all go together, fourteen days from today. They say we must get together the planks and the sacks and the tins and the poles, and all move together. They say we must all pay a shilling a week to the committee, and they will move all our rubbish and put up lavatories for us, so that there is no sickness. But what of the rain and the winter?

Two weeks from today, that is the day of the moving. Come my husband, let us get the planks and the tins and the sacks and the poles. I do not like the place where we are. There are planks at the Bragwanath Hospital, left there by the builders. Let us go tonight and carry them away. There is corrugated iron at the Reformatory, they use it to cover the bricks. Let us go tonight and carry it away. There are sacks at the Nancefield Station, lying neatly packed in bundles. Let us go tonight and carry them away. There are trees at the Crown 
Mines. Let us go tonight and cut a few poles quietly.

This night they are busy in Orlando. At one house after another the lights are burning. I shall carry the iron, and and you my wife the child, and you my son two poles, and you small one, bring as many sacks as you are able, down to the land by the railway lines. Many people are moving there, you can hear the sound of digging and hammering already. It is good that the night is warm and there is no rain. Thank you, Mr. Dubula, we are satisfied with this piece of ground. Thank you, Mr. Dubula, here is our shilling for the committee.

Shantytown is up overnight. What a surprise for the people when they wake up in the morning. Smoke comes up through the sacks, and one or two have a chimney already. There was a nice chimney-pipe lying there at the Kliptown Police Station, but I was not such a fool as to take it. 18

Although these settlements are better than no housing at all, it is obvious that they are not regarded by either the inhabitants or the government as satisfactory long-term solutions to the housing problem. It is equally obvious that the squatters, and many others, do not have the financial resources to successfully compete in the private housing market, especially in rapidly growing cities. Public housing policies arise, at least in part, as responses to situations of this sort and it is with these policies, the actors involved, the uses to which public housing may be put, and the motives involved that the housing sections of this essay are concerned. It is this great variety in possible permutations and combinations of responses, actors, uses and motives that make the housing policy field in Costa Rica and El Salvador so attractive to the analyst.

One possible policy response suggested from time to time is the simple transfer of funds to the ill-housed, enabling them to compete in the private housing market. This might work in areas where there was available a large amount of vacant if expensive housing. In rapidly 
growing areas such as San Salvador and San José, however, this practice would do no more than inflate the price of an already scarce commodity. Moreover, it is difficult for the granting agency to ensure the money is spent for housing. Some economists argue that this transfer payment approach would have the advantage of not distorting consumer preferences, but on the whole this is not a practical approach to alleviating the lot of the poorly housed.

Netzer has pointed out that in market economies, governments have equipped themselves with a large number of policy tools designed to increase the accessible supply of good quality housing, either in general or for selected income groups, by lowering the price at which housing is offered to consumers or offering special incentives for public and private builders of housing. 1

He divides these policies into four major types according to their principal effects, viz.

1. Subsidizing the initial outlay for land and construction of housing.

2. Making mortgage credit cheaper and more readily available.

3. Changing factors that affect the costs of construction and land and, thereby, the price at which a newly completed, unsubsidized housing unit can be sold or rented.

4. Affecting the tax burdens borne by housing occupants and investors in housing. 20

The idea of subsidizing 1 and and construction developed in Europe and was imported into the Americas. Agencies were created, either autonomous or semi-autonomous agencies of the national government or local public authorities, which issued bonds to raise the funds required for new housing. Rents, scaled to income, were collected from the tenants (in some cases the public housing clients purchased rather than 
rented, but rental is more common) and subsidies from the national government were used to make up the difference between revenue collected and costs. Tenancy in this kind of housing has, in the United States generally, been restricted to the very poor.

It is worth noting that some of the problems which have severely hampered this type of program in the United States have been weaker or absent in much of Latin America. The supposed stigma of living in a 'project' is missing. Despite the accelerating pace of suburbanization on the Anglo-American model, the outskirts of the city where land for subsidized housing is available are not necessarily the preserve of middle-income homeowners. In addition, the poor are usually not as ethnically distinct and distinguishable from their middle-class neighbors as is the case in many U.S. cities; hence there is not the same degree of antipathy toward them. We might expect to see, therefore, greater success with this sort of operation in San José and San Salvador than in Los Angeles or Detroit.

The making of mortgage credit cheaper and more available generally takes one of three forms. Of these, the most widespread is the provision of national government guarantees or insurance of conventional mortgages. Lenders, their losses covered, can then afford to offer mortgages at lower rates over longer terms with a smaller down payment. This scheme has benefited primarily lower middle- to middleclass families that may have been short on cash but had adequate longterm income prospects; it did little to help the truly poor.

The second credit policy involves the borrowing of funds by government at the lower rates it can command and the relending, at these 
lower rates, to individual builders and house buyers. The third credit policy is actually an expansion of the second. Here government provides mortgage credit at rates even below its own cost of borrowing. In effect it subsidizes the individual borrowers. While these policies reach farther into the low-income ranks than the first credit policy, once again they do not benefit the poorest. Often they are used to provide favored treatment to select groups; in the U.S., veterans, and in Latin America, public employees. It is worth speculating on the possible policy implications in this field of a totally nationalized banking system such as is found in Costa Rica.

Policies designed to actually decrease the costs of land assembly and housing construction are to be preferred, economically and politically, to the provision of subsidies. A difficulty here is that even if massive construction cost savings were achieved, the savings to the tenant would be small. If, for example, a reduction of one-quarter in materials costs and one-third in on-site labor costs were realized, monthly housing costs to consumers would decrease by less than ten per21 cent.

Nonetheless, there are possibilities for savings here, One way would be to replace outdated material standards for construction with performance standards. Other options include experimentation, more widespread abroad than in the U.S., with such concepts as cooperative housing construction and various forms of self-help. It would seem that the organizational skills and spirit of cooperation manifested by the squatters in their construction of tugurios could be channeled, with some governmental aid, into the construction of adequate permanent hous- 
ing. The extent to which this can be done will be examined below in our specific discussion of housing policies in Costa Rica and E1 Salvador.

The final policy tool to be considered here is the adoption of policies to reduce taxes on housing. Local property taxes cannot be passed on, either by homeowners or by landlords to tenants already spending the maximum they can possibly afford on housing. As a result, landlords either evict their poorest tenants where this is feasible or cut other costs such as maintenance. Once-adequate housing may thus deteriorate to the point where it is no longer habitable. The nature of the depreciation allowance under income tax regulations may affect, usually adversely, the quality of rental housing constructed. In this respect, as in so many cases, central government policy is often at odds with local government wishes. Where the landlord is an agency of the central government, it not only does not pay local property tax itself but removes from the rolls land that could be used for tax-paying private activities. Moreover, most local governments depend so heavily on the property tax that major reductions would severely restrict their ability to provide essential services. Useful policy tools here will arise only from expanded intergovernmental cooperation.

The actors in the field of provision of low-cost public housing are many and varied. The largest group is, of course, the clientele or potential clientele of the housing. In closest contact with the clients is the proximate supplier of the housing, generally a local or national governmental agency. Closely related to this agency are the other agencies providing such support services as water and electricity. Un- 
derlying all of this is the funding agency. In the U.S. this is most often the federal government. In Latin America, the national governments are usually unable to undertake the full funding of public housing; thus extranational actors come into the policy picture. These may be foreign governments such as the U.S. Agency for International Development (AID) or international bodies such as the Banco Interamericano de Desarollo (BID) and the International Bank for Reconstruction and Development (IBRD). Private extranational actors such as the Ford Foundation may also be involved. In addition to external funding agencies, outside actors providing technical expertise and aid may play a part in the policy process as well. Finally, nationally based private agencies may also be involved in the provision of low-cost housing. They will be considered here primarily in order to compare them with governmental agencies in terms of performance, efficiency, choice of client groups, motives and the nature of the decisionmaking process.

Public housing policy may have many uses in addition to the obvious one of providing lower-income people with a place to live. The government may use it for social experimentation. ${ }^{22}$ For example, it may wish to see if providing housing units of a certain size affects the birth rate or encourages the nuclear vis-a-vis the extended family. Housing policy may also be used to generate employment, both directly in the construction of housing units and indirectly in that workers engaged in this construction may develop or upgrade skills that are marketable in other sectors. In addition, housing policy may have a breeder effect, as for example encouraging the development of a local building materials industry. 
Sean Elliott suggests still another use, increasing productivity. He reports that the study of Vicos in Peru showed that housing per se was strongly related to worker productivity, enough so to justify the capital outlay. Elliott concluded that "low cost housing construction in Latin America is justified on economic as well as political and social grounds." This being the case, housing can be regarded as a capital good as well as a consumer good and occupy a whole different place in the development expenditure hierarchy. Finally, public housing may be used to influence migration and settlement patterns. This may be done locally to guide land use within the municipality or on a national scale to locate settlement appropriately in relation to planned employment opportunities and service delivery networks.

As varied as the uses to which public housing policy may be put are the motives that inspire its creation. The political system may simply be responding to a manifest need for shelter. Or it may see certain housing provisions as fitting into a general plan. The elimination of tugurios may be regarded as good housekeeping. Perhaps the government wishes to neutralize negative externalities from the illhoused sector of the populace such as the spread of fire, crime or vice into middle-class neighborhoods. It could be that the authorities wish to obviate the possibility of a cholera epidemic. The motives underlying the provision of low-cost public housing may be purely political; the system may be trading housing for votes, support, or overt recognition of its legitimacy. Or it may be necessary to pacify a citizenry on the verge of rebellion. Most likely, no one motive underlies all public housing policy but it is worth investigating to see which ones 
tend to be the strongest instigating forces in which polity under what conditions.

There does not exist a pure theory of public housing provision applicable in all situations as there exists a set of taxation principies. Nonetheless, there do exist criteria for the efficient operation of a low-cost, money-losing public housing scheme as well as a fairly generally usable set of objectives for housing policy in developing areas. Musgrave offers the following observation on efficiency from a public finance viewpoint:

In the efficient system, a loss operation in low-cost housing involves (1) a policy of distributional adjustment in favor of low incomes, since only low-cost housing is involved; (2) a recognition of housing as a merit want, since the distributional adjustment is not made in cash; and (3) a preference for public production management, since otherwise lowcost housing might have been provided by subsidies to private firms. 24

Charles Abrams recognizes that housing objectives in developing countries must by their very nature be situational, varying with such factors as financial resources, housing shortfall, level of economic development, state of the current housing supply, geographical considerations, and a myriad of social and political pressures. With this caveat in mind, he offers a set of policy objectives that "are probably appropriate for most countries." These thirteen objectives are:

1. Priority in Housing Production for Lower-Income Families 2. Opportunity for Homeownership by Low-Income Families at Low Costs

3. A Housing Program Offering Reasonable Choices of Environment

4. A Sound Financing Policy Enabiing Low - and Moderate-Income Families to Buy Homes 
5. Encouragement of Savings

6. A Sound System of Subsidies

7. A More Effective Building Industry

8. Reduction of Home Construction Costs

9. The Placement of Industry Where a Minimum of Housing Has

to Be Built

10. A Reasonable Program for Rehousing Squatters

11. Prevention of Squatting

12. Encouragement of Cooperation

13. Sensible Rent Controls or Their Repeal.

Many of these objectives have already been considered in our discussion of the sorts of policy tools governments have adopted to aid in the provision of accessible housing. These objectives will be examined in more detail as we consider which of them are particularly appropriate in San José and San Salvador, and the degree of success in meeting them in these urban areas. Two of the objectives, however, a sound system of subsidies and a reasonable program for rehousing squatters, merit further discussion here.

Whatever the precise nature of the subsidy, whether it takes the form of cash subsidy, deficit subsidy, interest rebate, writedown of land or building costs or some other form, four general rules guide the dispensation of subsidies. In the first place, a subsidy should serve a public purpose and be part of a defined, long-term objective. The legislative authorization should be clear and unambiguous, and not allow excessive administrative discretion. To this end the appropriation should be made periodically and not renewed without careful scrutiny of the agency's operations. 
Secondly, if there is a necessary choice to be made between single and multiple purpose subsidies, the multiple service subsidy is to be preferred. Subsidies for low-cost housing are rated high here because the same dollar not only provides housing but also, it is claimed, stimulates employment, reduces social tensions caused by squatting and cuts down on the whole variety of negative externalities associated with the housing shortage.

Third, the subsidy should be defined and certain, open and not hidden. It must be realized, however, that there are occasions upon which political realjties will require that the subsidy be kept out of sight.

Finally, subsidies should be distributed equitably and without favoritism within the group they are designed to serve. That is, if subsidies are destined for members of a certain income class, each member of that class should have equal access to the subsidy. Subsidies should not be used, for example, to reward the politically faithful who meet income criteria. Again, it should be remembered that these are ideal principles of subsidization and political realities could cause to last two especially to be honored primarily in the breach.

A program for rehousing squatters must contain two major elements: a fixed, known date for their removal from the squatter settlement and someplace for them to move at this time. The primary concern, therefore, is with the provision of housing, without which there can be no successful relocation. As far as possible, relocation of squatters should be carried out en masse, moving whole colonies if possible rather than one household at a time. The government should not dismiss the 
possibility that certain shantytowns might best be turned over to the squatters, with aid provided to help them upgrade their on-site housing and appropriate compensation paid to the owners of the appropriated property. It is worth noting that the problems facing governments in the relocation of squatters in the developing nations parallel closely those of the U.S. in its Urban Renewal programs. Had the public authorities in the U.S. heeded these basic relocation principles, it is possible that much of the citizen disenchantment with the 'Federal Bulldozer' could have been averted.

In the section above we have noted briefly some of the factors involved in public housing policy. Possible actors, motives, uses and policy responses have been considered. Some basic principles of efficiency in low-cost housing and objectives of housing policy for developing countries have been mentioned. It is with this tableau as backdrop that the housing policies affecting the urban areas of San José and San Salvador will be examined in Chapter VII. 
1. Cliff Kaufman, "Rejoinder to Joan Nelson," Journal of Comparative Administration (JCA) 4 (1972):375.

2. Rudolf Goldschied, "A Sociological Approach to Problems of Public Finance," in Richard Musgrave and Alan Peacock, eds., Classics in the Theory of Public Finance (New York: St. Martin's Press, 1967), pp. 202-213.

3. Joan Ne1son, "The Search for Useful Hypotheses," JCA 4 (1972), p. 365.

4. Luiz de Moraes, "En Busca de una Teoria."

5. Adolph Wagner, "Three Extracts on Public Finance," in Musgrave and Peacock, Classics, p. 11 .

6. See the discussion below, in Chapter VI, of San Salvador's efforts in this sphere.

7. See Richard Wagner, The Public Economy (Chicago: Markham Press, 1973), pp. 24-29 for a discussion of equity and justice as norms for fiscal organizations.

8. Richard Musgrave, The Theory of Public Finance (New York: McGrawHi11, 1959), pp. 90-115.

9. Ibid., p. 91 .

10. For an extended discussion of spillovers, see Dick Netzer, Economics and Urban Problems (New York: Basic Books, 1971), pp. 167181 .

11. Tax Foundation, Inc., "Nontax Revenues: Selected Economic Issues," in William Mitchell and Ingo Walter, eds., State and Local Finance (New York: Ronald Press Company, 1970), p. 194.

12. The figure for local government is from David Davies, "Financing Urban Functions and Services," in Mitchell and Walter, Finance, p. 322; the figure for the federal government is an estimate from various economists.

13. Alan Prest, Public Finance in Underdeveloped Countries, 2nd. ed. (New York: Halsted Press, 1972), p. 130.

14. De Moraes, "En Busca de una Teoria," p. 117. 
15. Joseph Fried, Housing Crisis, U.S.A. (New York: Praeger, 1971), p. 19.

16. Marcia Koth, Julio Silva and G.H. Dietz, Housing in Latin America (Cambridge: Massachusetts Institute of Technology Inter-American Program in Civil Engineering Research Report, 1964), p. 39.

17. The local names given to these settlements vary from place to place. In Mexico they are called vecindades; in Rio de Janeiro, favelas; in Lima, barriadas; and in Caracas, ranchos. The term tugurio is widely used in Costa Rica and El Salvador and will be adopted in this essay.

18. Alan Paton, Cry, the Beloved Country (Harmondsworth, England: Penguin Books, 1972), p. 50, 52 .

19. Netzer, Economics and Urban Problems, p. 79.

20. Ibid., p. 83 .

21. Ibid., p. 92.

22. I am grateful to Lois Copperman for pointing out the extent to which this is being done in the Soviet Union and elsewhere.

23. Sean E1liott, Financing Latin American Housing (New York: Praeger, 1968), p. 3.

24. Musgrave, Theory of Public Finance, p. 29.

25. Charles Abrams, Man's Struggle for Shelter in an Urbanizing World (Cambridge: M.I.T. Press, 1964), pp. 219-239. 


\section{BACKGROUND FACTORS}

It has been stated that we assume a number of political, social and economic background factors affect both the policymaking process and the policy products in San José and San Salvador. These factors have been listed above, page 11. In this chapter these specific factors are examined with a view to both assessing their individual impacts and determining which ones vary sufficiently between the two cities as to possibly account for differences in policy.

\section{POLITICAL FACTORS}

The political considerations, again, are

1. Structure of city government

2. Relations between municipal and national governments

3. Role of parties and elections

4. Importance of non-governmental groups in the policy process

5. Policy preferences of leaders of city governments

These categories are not all mutually exclusive; certain elements might as well be considered in one as in another. Nonetheless an attempt will be made here to examine the various data under the most logically appropriate headings. 
Structure of City Government

Under the structure of city government the following are included: constitutional provisions, legal duties and obligations, legislative and administrative organization. A reasonable argument could be made for treating the constitutional milieux of the cities in the section on national-local relations. However, we have decided that because of the preeminence of this topic and its function as a base for examination of other political factors it merits discussion prior to any of the others. The sections of the constitutions dealing with municipal governments are as brief as they are important. Consequently, they are reproduced here in their entirety.

In the Costa Rican Constitution, the eight articles dealing most directly with municipal government are compiled into one chapter as shown below.

Article 168. For purposes of public administration, the national territory is divided into provinces; these are divided into cantons and the cantons into districts. The law may establish special circunscriptions.

The Legislative Assembly, by observing the requirements for the partial amendment of this Constitution, may create new provinces, provided that the respective proposal is previously approved by a plebiscite which the Assembly shall order to be held in the province or provinces which are to be divided.

The creation of new cantons must be approved by the Legislative Assembly by a vote of not less than two thirds of the entire membership.

Article 169. The administration of local interests and services in each canton shall be entrusted to a municipal government, consisting of a deliberative body composed of municipal regidores selected by popular election and such executive official as the law may determine.

Article 170. Municipal corporations are autonomous.

Article 171. Municịpal regidores shall be elected for a term 
of four years and the position shall be compulsory.

The law shall specify the number of regidores and the manner in which they shall serve. However, the municipalities of the central cantons of provinces shall consist of not less that five titular regidores and a like number of alternates.

The municipal officials shall be installed on July first of the corresponding year.

Article 172. Each district shall be represented in the municipality of the respective canton by a titular sindico and alternate, with the right to speak but not to vote.

Article 173. Municipal ordinances may be:

1) Objected to by the official whom the law designates, by a veto with explanation;

2) Appealed by any interested party.

In either case, if the municipality does not revoke or amend the ordinance objected to or appealed, the case shall be referred to such court of the judicial power as the law may specify, for final decision.

Article 174. The law shall specify those cases which the municipalities require legislative authorization to contract loans, encumber their properties or revenues, or alienate movable or immovable property.

Article 175. The municipalities shall fix their ordinary and extraordinary budgets which, in order to take effect, must be approved by the comptroller general, who shall supervise their execution.1

Additional constitutional provisions affecting municipalities in

Costa Rica provide that: the ordinary budget include all probable revenues and authorized expenditures for the fiscal year, expenditures may not exceed probable revenues and the fiscal year is the calendar year (Article 176); contracts for execution of public works, purchases and sales or leases of property must be through bids (Article 182); the comptroller general is to examine and approve or disapprove the municpal budgets, their execution and liquidation (Article 184[2]) . 
In the Salvadorean Constitution, Chapter One of the section on the Administrative System contains the seven articles specifically addressed to local government. These are:

Article 101. For purposes of political administration, the territory of the republic is divided into departments, the number and boundaries of which shall be fixed by law. Each department shall have a governor and a substitute governor, appointed by the executive power.

Article 102. To be a governor the following qualifications are required: to be a Salvadorian, a layman, over twentyfive years of age, to be in exercise of the rights of citizenship, having been so for three years immediately preceding his appointment, to be of well-known morality and education, and a native or resident of the department. In the latter case, two years' residence immediately preceding appointment is necessary.

Article 103. For purposes of local government, the departments are divided into municipalities, which are governed by municipal councils consisting of a mayor (alcalde), a syndic (sindico) and two or more aldermen (regidores), the number of whom shall be in proportion to the population.

The members of the municipal council shall be elected for a term of two years, may be reelected, and their qualifications shall be determined by law.

Article 104. Municipal funds may not be centralized in the general funds of the state and may not be used except for municipal services.

The municipal councils shall administer their resources for the benefit of the community, and shall submit detailed and documented accounts of their administration to the appropriate court.

Article 105. The law shall specify the powers of the municipal councils, which shall be purely economic and administrative.

The municipal councils are autonomous in the exercise of their functions. As juridical persons, they are liable for their acts as a body, or their individual members may be so liable, as the law may prescribe.

They sha1l prepare their schedules of local taxes, to be submitted to the Legislative Assembly for enactment as laws, and that body may make any changes deemed necessary. 
Article 106. Municipal councils may appoint their own officials and employees without the intervention of any other authority.

Article 107. The executive power shall see that municipal councils comply with the laws, but he shall always respect municipal independence. 2

Further provisions of the Salvadorean Constitution relating to municipalities provide that: the National Assembly is to authorize the executive power, by a vote of not less than two-thirds of the deputies, to guarantee obligations of public interest contracted by municipal entities (Article 47-16); all rules governing conduct of public employees, the establishment of a career administrative service, and the prohibition of strikes by public employees, extend to municipal employees (Article 111); contracts for public works or the acquisition of personal property for which public funds are to be expended must be submitted to public bids (Article 127); neither the legislative nor the executive branch may relieve officials and employees who manage municipal funds of the obligation to pay sums of money retained by them, nor dispense with the payment of debts due the municipalities (Article 133).

A number of similarities, and differences, between the two constitutions as they relate to municipalities are immediately evident. Among the similarities, both begin by describing the subnational territorial system, of which the municipalities constitute an important part. Legal and political linkages between these and the intermediate units, termed departments in El Salvador and provinces in Costa Rica, will be examined below in the section on intergovernmental relations. Nonetheless a brief description of the structure is appropriate here. Costa Rica is divided into seven provinces. The province of San 
José contains about ten percent of the land area and 30 percent of the inhabitants of the country. This province is in turn divided into 20 cantons, the central one of which is also named San José. The canton is in its turn composed of 11 districts, four of which have the rank of city and seven the rank of barrio. Minor subdivisions, some of which are also called barrios and others poblados al so exist. These, however, have no legal standing and may be regarded as neighburhoods. The four districts mentioned above with the rank of city-Carmen, Merced, Hospital and Catedral--together constitute the City of San José. This, however, is not the unit with which we are here concerned; our concern is with the municipality, which includes all 11 districts. Its formal title is the Municipality of the Central Canton of San José. Unless otherwise specified all legal or political references to San José are to this municipality.

El Salvador, although much smaller than Costa Rica, is divided into 14 departments located in three zones: West, Central and East. The departments are composed of districts which are in turn subdivided into municipalities. Municipalities are classed according to size as cities, villas or pueblos. This ranking is merely a 'hierachy 3

of honor'; there are no differences in powers or duties among the various classes of municipalities. The Department of San Salvador contains the District of San Salvador in which is located the Municipality (or City) of San Salvador, the legal entity with which we are most concerned. There exist within the municipalities smaller divisions called cantons which are analagous to barrios (second meaning) and poblados in Costa Rica. These will not be considered further for two reasons: 
they have no legal-political standing and the differing use of the term canton in the two countries could lead to confusion on the part of the reader. A complication arises in that certain statistics are collected for, and the general plan encompasses, Metropolitan San Salvador (Metro) which includes the entire District of San Salvador and part of the District of Nueva San Salvador in the adjacent department, La Libertad, but does not include the rest of the Department of San Salvador. This complication will be dealt with as it arises in the course of this essay.

In each country the constitution provides that local government shall exist to look after local interests and, moreover, that such 10cal government is to be elected by the citizenry it serves. El Salvador and Costa Rica both reguire the size of the governing body to be related to the size of the population governed. Each constitution imposes severe constraints upon the municipality's fiscal freedom; budgets and tax structures must be approved by agencies of the national government. Furthermore, the municipality in each country is constitutionally required to let public works and purchase contracts only through open competitive bids.

Municipal autonomy is referred to in both constitutions; on this topic there are some similarities and some differences. The Costa Rican Constitution provides that "the municipal councils are autonomous in the exercise of their functions" and that they "may appoint their own officials and employees without the intervention of any other authority" but their powers are limited to the "purely economic and administrative," revealing apparent antimony within the constitution it- 
self.

At this point some divergence in the two constitutions, in their provisions respecting municipalities, may be noted. Costa Rican municipal officials are to be elected for four years, Salvadorean for two years. El Salvador provides for the separate election of an alcalde (mayor) and sindico (legal officer) along with the regidores (councillors); Costa Rica provides for the election of only the regidores, who as a body are to select and appoint the executive officers. It is worth noting here, to avoid further confusion, the difference in the term sindico as used in the two countries. In El Salvador the term refers, as mentioned above, to the municipality's chief legal officer. In this he combines the roles of counsel, solicitor, attorney, auditor and bill collector, and is second only to the alcalde in power and prestige. The Costa Rican sindico is chosen by a neighborhood to be its spokesman. He is nothing more. He attends council meetings with the right, as the Constitution puts it, "to speak but not to vote." To avoid difficulties the term sindico will not be used further in this essay. The English term syndic is dismissed as vague and imprecise. Sindico in the Salvadorean sense will be rendered as legal officer; in the Costa Rican sense, as neighborhood representative.

The very existence of the office of sindico in the Costa Rican sense points up another constitutional difference. While this sort of popular participation in municipal decisionmaking is mandated in the Costa Rican Constitution, it is nowhere mentioned in the Salvadorean. The latter does, however, contain two provisions not found in the former. One requires that municipal funds held in trust not be comingled 
with general national funds; the other that city councillors are liable severally as well as jointly for their acts.

Apparent differences in constitutions may not mean actual differences in law or practice. One country's constitution may speak to an issue which the other ignores, but statutes may make up for the omission. Costa Rica, for example, constitutionally compels acceptance of the office of regidor by any person elected thereto while the Salvadorean Constitution is silent on this point. However, the Salvadorean Law of Municipal Concern (hereafter referred to as the Municipal Act) does make acceptance of the office mandatory. Likewise in El Salvador the Constitution allows for the reelection of regidores; in Costa Rica the Constitution says nothing on this point but the Municipal Code provides for such reelection. Further, the Constitution of El Salvador mandates a career civil service system for municipal employees. The Constitution of Costa Rica does not but this nation's Labor and Municipal Codes effectively set one up.

These, then, are the important constitutional provisions relating to municipalities in El Salvador and Costa Rica. But as basic as the constitutions are to an understanding of municipal operations they are only necessary and not sufficient. Constitutional rights and duties provide the skeleton for the municipal system. It remains now for us to examine the muscles and sinews and blood.

The duties and obligations of municipalities in the two Central American republics include the usual ones familiar to those students acquainted with the Anglo-American municipality as well as a number that are less familiar. Municipal corporations in E1 Salvador, like 
many in North America, are responsible for, among other concerns: maintaining public order; construction and repair of streets; compiling vehicle and pedestrian statistics; promotion of institutions to improve public morality; maintenance of public transportation; regulation of usage of roads, streets and bridges, with respect to subsurface drains, powerlines, and automobiles; setting up public health authorities; maintaining both a civil register (births, deaths, marriages and divorces) and a voter's 1ist; and establishing libraries and elementary schools. Unlike most North American cities, those in El Salvador are also required to: conserve fish in rivers and lakes; guard the watersheds; insure twenty-four hour pharmacy service; publish books and monographs diffusing useful knowledge; regulate both transactions in the municipal market and weights and measures; and protect against forest fires. This last requirement, in fact, is specified to the extent that Article 17 of the Municipal Act requires each municipality, at its first session of the year, to appoint a forest ranger paid out of municipal funds. This same Article levies a fine on any property owner who allows the destruction of any tree or bush on his property, if this plant cover is deemed necessary for the well being of the city's watershed.

In those matters of particular concern to this study, municipalities are obligated to collect all monies owing them, keep assessments up to date, and pay their own bills each month. No mention is made of any municipal responsibility for the provision of publicly funded or assisted housing.

Costa Rican municipalities are broadly charged with "the admin- 
istration of local services and interests toward the end of promoting the integral development of the cantons in harmony with national development." More precisely, they are to: promote the progress of culture, science and art; establish public libraries; hold seminars and conferences, give energetic impulses to education by, among other practices, awarding scholarships to low-income students; guard the physical and mental health of the inhabitants; and establish an integrated policy of urban planning. This last is to guarantee, at least, electricity, communications, water, sewers, streetlighting, construction and repair of streets and a program of parks, gardens and open spaces. Among other duties of municipalities are: economic development, including agricultural; promotion of full employment; conservation of natural resources; maintenance of public order and security; and the encouragement of internal and external tourism. Finally, the cities are to:

promote the civic conscience of the population to the end of [creating] citizens exercising the principles of democratic self determination, participating opportunely and conscientiousiy in the activity of municipal government. 6

The municipalities of Costa Rica are also required to cooperate with one another in the provision of works or services when this would lead to better public service. Any agreements signed by municipalities in this sphere are legally binding upon them and must be approved beforehand by the Comptroller General.

Two separate sections of the Municipal Code address the matter of public housing. In Article 41-5 the municipalities are required to "establish . . . housing programs of social interest" in the urban area and in Article 41-6 are ordered to "formulate . . an adequate plan 
for the construction and upgrading of rural housing." Provisions of the Municipal Code dealing with revenue specify that municipalities are to collect their revenues every quarter, levying a two percent monthly service charge on any amount overdue, and that tax rates are to be revised periodically. Municipalities are given the right to adopt any tax, charge or other form of revenue except those used by the national government. More details are provided in the section bebelow on national and municipal tax structures.

Legislative organization varies considerably between the two cities. In North American terms, San Salvador has a strong mayor system with the council elected at large, while San José has a council manager form, also with at-large elections. In both cities elections are on a partisan basis but there exist important differences. Each contending party in San Salvador offers an entire slate--mayor, legal officer and councillors--and the entire slate is elected or defeated. Councillors in San José are elected according to the proportion of the popular vote their party receives, using the quotient or modified d'Hondt system. ${ }^{7}$ This is discussed more fully in the section on elections, and in Appendix C.

More precisely, San José is governed by a legislative body of 13 councillors and 13 alternates. Alternates serve in the case of absence of a councillor from a meeting for any reason whatsoever. The party composition of the councillors and the alternates is the same. If, for example, one PLN councillor is absent, the PLN alternate on top of the list substitutes for him. Thus the representation of the various parties remains the same, even if all councillors should be 
absent and replaced by alternates. Municipal elections take place every four years on the same date as presidential and national assembly elections. There is also a neighborhood representative, with an alternate, from each of the 11 districts. They have the right, as explained above, to speak but not to vote. The council elects its own president by secret ballot for a renewable one-year term. Both councillors and alternates vote but only regular councillors are eligible to hold the office. A majority of the votes cast is necessary for election.

Each district, 11 in San José, also has a five-member district council. One member must be the elected district representative; usually the alternate is also a member. The remaining district councillors are appointed by the municipal council from among the inhabitants of the district for a two-year term. They may be reappointed. Article 64 of the Municipal Code assigns district councils six functions:

a) serving as organs linking the municipality and the communities

b) being organs of collaboration with the municipality

c) controlling the municipal works carried out in the district and informing the municipal executive as to how well they are being done

d) preparing annually a list of the public works most needed in the district

e) receiving contributions or raising other funds and immediately turning them over to the municipality, with the funds earmarked for purposes agreed upon by the district council

f) whatever else falls under the care of the council, congruent with its nature and ends. 
The Comptroller General has determined that district councils, like municipal corporations, are juridical persons. In practice, however, their role seems to be purely advisory.

The legislative structure of San Salvador is much simpler than that of San José. A mayor, a legal officer, 12 councillors and two alternates are elected for two-year terms. Municipal and national assembly elections, may not, by law, coincide with presidential elections. As both a member of the council and chief executive officer, the mayor is the preeminent political figure in the city. No neighborhood representatives are elected, nor is there any equivalent of the district councils found in Costa Rican municipalities.

Committees are to be set up in both municipal councils. Four standing committees are in fact mandated by the Salvadorean Municipal Act. These are:

a) Public instruction, police, jails and public works

b) Roads, streets, plazas and sanitation

c) Streetlighting, street cleaning and public decoration

d) Markets, slaughterhouses, water services, weights, monies and measures.

Other committees established by the San Salvador council include: services, community action, finance, administration and personnel, and planning. The four required committees are to be made up of councillors; individuals may be asked to serve on the other committees if the council feels this is necessary. Individuals are free to refuse these requests. Committees have the power to oversee municipal services in their purview and to demand data and reports from administrative personnel but cannot issue orders or spend funds independent of the council 
as a whole.

San José has established eight standing committees and may from time to time augment these with interim committees as the council feels appropriate. The eight standing committees are: finance and budgeting, public works, juridical matters and police, public health and deccation, transit and urbanization, social work and scholarships, culture and sport, and protocol and public relations. Members are named to all of these by the president of the council. Finance and public works are to have seven members, of whom four must be councillors or alternates. The other standing committees are made up of five members of whom three must be councillors, alternates, or neighborhood representatives. Interim committees may contain any number of councillors not less than three. No councillor or alternate may be named to more than two standing committees nor head more than one.

Each committee at its first meeting, which must be held within 15 days of its creation, is to name a president and a vice president and hire a secretary. The secretary is to be a municipal employee, paid a salary determined by the committee. If the council president deems it necessary he may appoint a municipal employee from the area of concern to serve as coordinator between the committee and the municipality. Although it is not required, make up of the committees usually parallels the political composition of the council as a whole. If the committee cannot agree on a report or recommendation to the council, majority and minority reports may be presented for the council's consideration.

One final aspect of the legislative organization of the municipal- 
ities of San Salvador and San José is the frequency with which the respective councils meet and the parliamentary procedures at the meetings. Article 68 of the Salvadorean Municipal Act requires one meeting of the municipal council each month, between the first and the fifth. Extraordinary sessions may be called by the mayor or a majority of the councillors, with 24 hours written notice. Such sessions are seldom called. The agenda for meetings, again specified by statute, consists of:

1) the mayor gives an account of how the policies and directives of the previous meetings are being carried out and mentions any important happenings since that meeting

2) the municipal secretary gives an account of all correspondence received, resolutions and other business that the council ought to be cognizant of, or requiring its resolution

3) the standing committees report on their work

4) the interim committees report on their work

5) the council considers, discusses and resolves any new business arising from the above.

The council is to resolve every issue raised at the meeting at which it is raised. A majority of the councillors are necessary for a quorum, and passage of any act or resolution requires a majority of the votes cast. In case of a tie the mayor gets a second vote to break the tie. Councillors may be fined up to ten colones for absenting themselves from a council meeting without due cause.

In San José the municipal council schedules three regular meeta week: on Monday, Thursday and Friday. Extraordinary sessions may be called; however, since the per diem is paid for only 12 (or fewer) meetings a month, these sessions seldom occur. On Mondays and Fridays 
the agenda consists of:

1) Reading of the minutes of the previous meeting

2) Correspondence

3) Accounts

4) Committee reports

5) Matters of urgent concern, as defined by the council president

6) New business.

The chiefs of the various city departments are required to attend these meetings.

Thursday meetings are designed to serve a different purpose. Consequently their agenda appears thus:

1) Reading of the minutes

2) Matters of urgent concern

3) Audiences

4) Correspondence (if time allows)

5) New business.

The audiences consist of

receiving individuals, groups of neighbors, representatives of communities or associations, with an interest in treating matters of canton or district character, and whom, having previously solicited, the council president has fixed an audience for that day. ${ }^{9}$

Department heads are not required to attend this meeting unless a matter to be raised during the audiences concerns their departments.

A quorum consists of eight councillors in their chairs and ready to begin within 15 minutes of the time for which the meeting is scheduled. A majority of those present and voting are necessary to pass most resolutions. Certain matters, however, such as the firing or 
suspension of the auditor or municipal executive, require a vote of two-thirds of all regular councillors. Councillors absent from a meeting, excused or not, do not receive the 150 colones ( $\$ 150$ ) per diem. An alternate taking a regular councillor's place receives the per diem; other alternates do not. The neighborhood representatives in attendance at sessions receive a per diem of $\$ 112.50$.

Although the legislative structure of San Salvador is much simpler than that of San Jose, the former municipality has a vastly more complex administrative structure. 10 Organograms of the two structures may be found on pages 125 and 127. An expanded table of the structure for each city is located in the Appendices. It is appropriate at this point however to examine very briefly the organizations in the two municipalities and to note some of the important differences between them.

San Salvador is considered first, because it has the more complex structure. It is worth recalling here that the chief executive officer (alcalde) is elected in San Salvador and thus serves as both administrative and political leader. The same is true of the legal officer, the number two person in both political and administrative hierarchies. The legal officer not only runs the legal office but also provides such services to the other entities as may be necessary. As shown in the chart, three areas are directly under the alcalde--police, public relations, and secretary. The secretary is the highest ranking appointee; although not protected by civil service he usually serves through several administrations. Chief concerns of the secretary are correspondence, petilions ard other communications with the council, and maintenance of the municipal archives. 


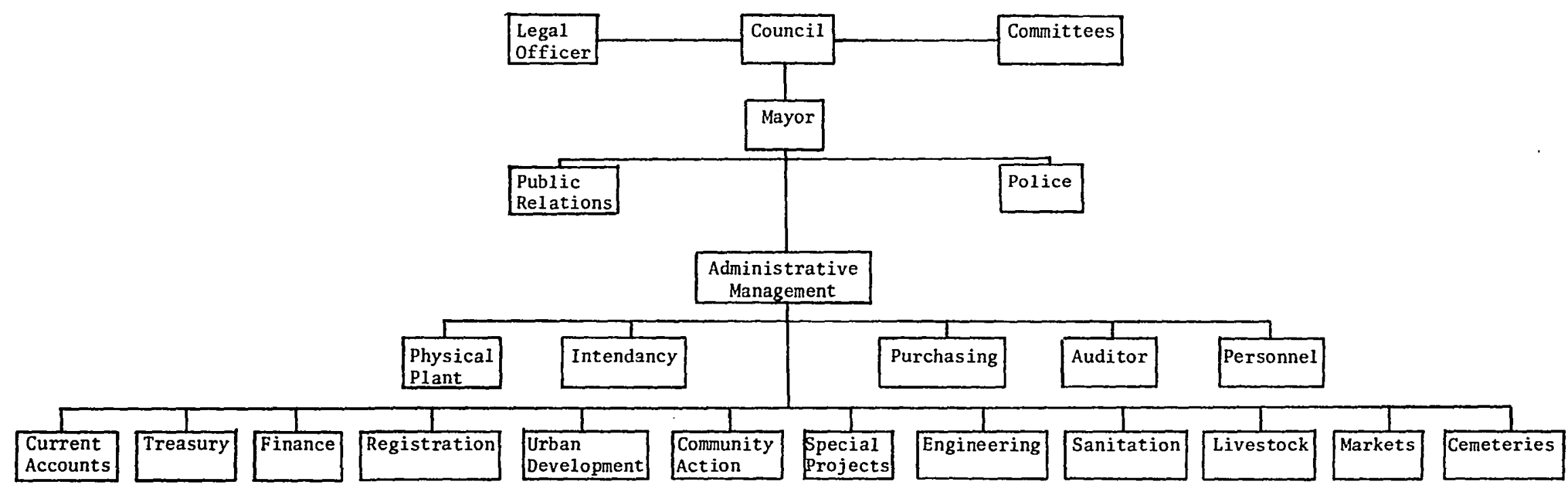

Figure 10. Municipality of San Salvador administrative structure. 
Other than the four areas mentioned above, municipal services and employees are directed by the general office of administrative management. The office is technically headed by the secretary. Immediately below this office are the five support services: physical plant, intendancy, purchasing, auditor and personnel office. Included as parts of the physical plant are motor pool and general stores. Most of these units serve the same functions as their counterparts in AngloAmerican municipalities; the intendancy however has no perfect, or even approximate, counterpart. It is responsible for: providing uniforms for drivers, porters, messengers and police; looking after cleaning supplies; provision of meals to certain municipal employees; cleanliness of public toilets and baths; and maintenance and repair of office equipment and parking meters.

Below the five support services are the 12 line functions described in more detail in Appendix D.

The administative organization of San José is somewhat simpler than that of San Salvador. Here it will be examined from a functional viewpoint, rather than according to administrative unit. Both the budget and the assignment of personnel are organized in this way; thus it seems the more appropriate approach. A detailed breakdown of the municipal bureaucracy is found in Appendix E.

Heading the administration of San José, however viewed, is the municipal executive. Unlike the case in San Salvador, he is appointed by majority vote of the council and not elected by the voters. The appointment runs four years, roughly concurrent with the term of the municipal council, and may be renewed. A vote of two-thirds of the 


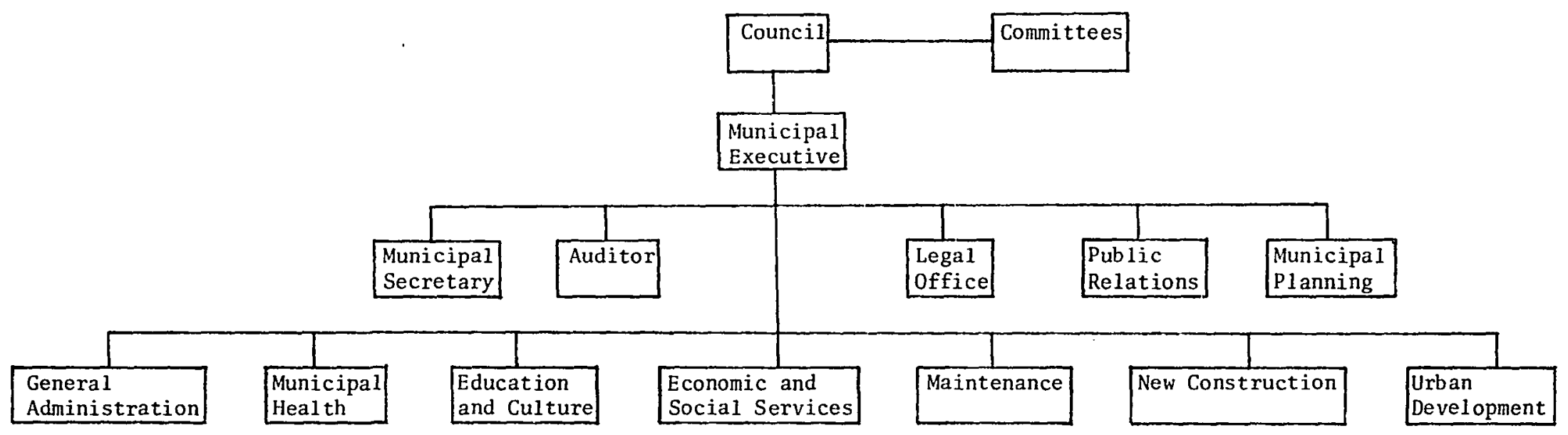

Figure 11. Municipality of San Jose administrative structure 
total membership of the council, nine out of the 13 councillors, is required for removal from office.

Generally the powers and duties of the municipal executive are similar to those of the manager in a North American city with a councilmanager form of government. Article 57 a) of the Municipal Code entitles and requires the executive to

exercise the functions inherent in the role of general administrator and chief of the municipal departments. overseeing their organization, functioning and coordination and insuring the faithful fulfillment of municipal ordinances and laws and rules in general.

The executive is a 'pure' city manager; there are no municipal employees, save the auditor, outside his jurisdiction.

Immediately beneath the municipal executive are the five offices which together constitute the Directorate General of Municipal Development Policy. These offices are secretary, auditor, legal office, public relations and municipal planning. The secretary, as in San Salvador, basically serves the council and runs the municipal archives. The auditing and public relations functions are the usual. The legal office provides comprehensive services, filling the roles of counsel, solicitor, and in some cases, prosecutor. All municipal legal work is centralized here. The planning office carries out such urban planning, primarily physical, as the Municipal Code requires. 12 The seven line functions are presented more completely in Appendix E.

General organization of the two municipal governments, then, is as described above. Briefly, some of the more significant differences between San Salvador and San José are:

1) greater complexity of the administrative organization in San Salvador 
2) executive as elected politician in San Salvador and appointed administrator in San José

3) existence of a planning function at the municipal level in San José but not in San Salvador

4) municipal provision of police services in San Salvador

5) collection of vital statistics at the municipal level in San Salvador

6) financial contributions to education in San José

7) essentially agricultural services such as extension programs and livestock handling in San Salvador

8) issuance of cedulas by the municipality in San Salvador

9) presence of a formal community development function in San Salvador.

These differences are not only important as contrasts between the two municipalities per se, they also represent variations in relations between national and municipal governments in the two countries. These are examined in greater detail in the next section. Services provided by the Municipality of San Salvador but not by San José are generally undertaken in Costa Rica by the central government, and vice versa. In El Salvador, for example, municipal planning in general and preparation of the Metropolitan Development Plan for San Salvador in particular are the responsibility of the Ministry of Public Works and the National Council for Economic Planning (CONAPLAN) . In Costa Rica, police services are provided by the Ministry of Public Security, cedulas are issued by the Supreme Electoral Tribuna1 (TSE) and community development is the responsibility of the National Directorate for Community Development (DINADECO).

It should be noted that a number of what are regarded as essen- 
tially municipal services in Anglo America are not provided by either municipality. Neither San Salvador nor San José provides the public water supply or constructs sewers; these are central government functions. Streetlighting is provided by private companies in both cases. Fire protection is provided by volunteers in San Salvador and by the National Insurance Institute (INS) in San José. All of these things point to a vastly different set of relationships between municipalities and superior governments in the two Central American nations than those existing in North America.

\section{Relations Between Municipal And National Governments}

Generally, relations between the municipalities and the national governments are of three broad types: direct fiscal and administrative relations; service area relations, usually between the local government and autonomous agencies; and political relationships. A number of these have been discussed in the previous section; they will be recalled only briefly here.

Both countries, it was noted, are subdivided into political divisions, called provinces in Costa Rica and departments in El Salvador. Each subdivision has a governor appointed by the national executive. In Costa Rica this is a ceremonial position with little power and no direct connection with local government.

In El Salvador, however, the governor has a good deal of direct control over the municipality. He is to inspect the general operation of the municipalities and can hold the responsible mayors answerable for any shortcomings he finds. Legal officers are to report any infractions to him. He is in charge of the national police in his jurisdic- 
tion and can take control of the municipal police when he deems it necessary. Moreover, he can even fine mayors for failing to comply with his orders. In case of the governor's absence or incapacity, his place is taken by the mayor of the chief city within the department.

The importance of fiscal relations between municipal and central governments cannot be exaggerated. Central controls, it will be remembered, are similar in the two countries. In El Salvador, the national Court of Accounts must approve the municipal budget before it comes into effect; in Costa Rica the Comptroller General has this responsibility. Municipal expenditures over a certain amount also require central approval. In San Salvador the vo.Bo. of the Ministry of the Interior is required for all expenditures over $\phi 5,000$. Only San Salvador has a limit this high; other municipalities, depending on their population, have limits of $\$ 100$ to $\$ 3,000 . \quad(\$ 1.00$ U.S. $=\$ 2.50$ E.S.) The limits mean that

the municipalities are obliged to solicit permission for the purchase of a simple desk, perhaps because it is considered that this act of the municipalities could compromise the national sovereignty. 13

In Costa Rica the Comptroller General has the power to modify any municipal budgets as he sees fit. Central government approval is required for any ordinance encumbering funds in the amount of $\$ 5,000$ or over, any contract involving $\$ 10,000$ or over and any real estate transaction for more than $\$ 50,000$. ( $\$ 1.00$ U.S. $=\$ 8.45$ C.R.) Additional fiscal controls over the Municipality of San José include the requirements that expenditures and revenues balance each month and that any funds raised in a certain district of the city be expended 
in that district.

In both Costa Rica and El Salvador all municipal taxes--and changes in municipal tax rates--must be approved by the national legislature become coming into effect, and both countries are singularly reluctant to approve new taxes for their capitals. In our discussion of specific issues we will examine the attempts by San Salvador to reform its tax structure, and the blocking of this attempt at the national level. For San José we will chronicle the difficulties faced by the municipality in its ultimately successful effort to install parking meters. It should be noted, moreover, that although most Costa Rican municipalities have their requests for new taxes and rate changes rather routinely approved, San José has not been allowed a tax increase since 1935.

If these fiscal relations appear one-sided, control-oriented and, from the municipal point of view, obstructionist, there is in Costa Rica a balancing factor. The national government does provide money for the municipal treasuries, and more, proportionately, for San Josê than for other cities. Specifics will be examined in the section on taxes. No such subventions benefit San Salvador. In fact, the central government does provide some funding for other cities but none at all for the capital. Control, then, characterizes the central government's role in the financial affairs of San Salvador.

"If strict fiscal controls are one side of the coin of municipal dependency, the role of the central government in many of the 14

city services is the other." Ebel investigated 21 services generally regarded as municipal and found only two, street cleaning 
and street nomenclature, completely under the control of the Municipality of San Salvador. (Garbage collection is also a totally municipal function; it is not one of the services he examined.) The municipality, however, played some role, albeit usually a secondary one, in the provision of ten other services.

A variety of non-municipal actors take part. Water and sewage, for example, are totally outside municipal control, being provided by the semi-autonomous National Administration of Aqueducts and Sewers (ANDA). Traffic control is completely in the hands of the Ministry of Public Works and Transport (MOPT). Street construction and maintenance is the function of the Directorate of Urbanism and Architecture (DUA), another semi-autonomous agency, but there is some participation by the municipality. Policing is provided by the Ministry of the Interior (MI) and the municipality. Streets are lighted by the private, Canadian-owned, San Salvador Illumination Company (CAESS) under municipal regulation. Building permits require the Vo.Bo. of IVU, DUA and the municipality. The hand of the central government is found in even the most unlikely places. MOPT, for example, has a role in the municipal markets while CONAPLAN takes part in the planning of the municipal fair.

Chávez Mena has levelled criticism at yet another aspect of national government interference with municipal concerns of San Salva15

dor. He charges it with franchising private corporations to carry on profitable activities that might well otherwise be carried on by municipal enterprises. One example of this is the provision of public transportation. As alien as the thought may be to a North American 
mind, bus service in San Salvador, and for that matter in San José, does make money.

Functional relations between the Municipality of San José and the Costa Rican government resemble the Salvadorean situation. Again we find both new and used water being carried about by an autonomous agency, the National Service of Aqueducts and Sewers (SNAA), which also has veto power over housing developments. AlI policing, except the guards at the municipal markets, is provided by the central $\mathfrak{s}_{\mathrm{ov}}$ ernment. Street 1 ighting and mass transit services come from private corporations. There are some services, however, in which the Costa Rican municipality plays a greater role than its Salvadorean counterpart. Among these are traffic control, road maintenance, and urban planning. Figure 12 below compares the participation of central and local governments in the provision of selected services generally regarded as municipal. When more than one agency has a significant part, they are listed in order of degree of participation.

Generally speaking, the municipalities are not happy with the assumption of what they regard as their prerogatives by agencies of the central government. Active response, however, has been quite different in the two municipalities. San Salvador, making the best of what it considers a bad situation, cooperates readily with the agencies. San José, on the other hand, engages in constant bickering, 16 espcially with SNAA.

It is worthwhile here to speculate as to possible reasons for this difference. One might be the greater openness of the Costa Rican political system--San José can 'get away with it'; San Salvador is not 


\begin{tabular}{|c|c|c|}
\hline Service & San Jose & San Salvador \\
\hline Police & MPJG & $\begin{array}{l}\text { MI } \\
\text { Municipality }\end{array}$ \\
\hline Fire & INS & Volunteer \\
\hline $\begin{array}{l}\text { Street construction and } \\
\text { maintenance }\end{array}$ & Municipality & DUA \\
\hline Street cleaning & Municipality & Municipality \\
\hline Street nomenclature & $\mathrm{CIN}$ & Municipality \\
\hline Street lighting & Fuerza y Luz & CAESS \\
\hline Garbage collection & $\begin{array}{l}\text { Municipality } \\
\text { MSP }\end{array}$ & Municipality \\
\hline Water & SNAA & ANDA \\
\hline Public transportation & Private & Private \\
\hline Parks and recreation & $\begin{array}{l}\text { Municipality } \\
\text { MNJ } \\
\text { DGD }\end{array}$ & $\begin{array}{l}\text { Municipality } \\
\text { FOCCO }\end{array}$ \\
\hline Sewers & SNAA & ANDA \\
\hline Cemeteries & Municipality & $\begin{array}{l}\text { Municipality } \\
\text { CONAPLAN }\end{array}$ \\
\hline Traffic control & Municipality & MOPT \\
\hline Building permits & $\begin{array}{l}\text { Municipality } \\
\text { INVU }\end{array}$ & $\begin{array}{l}\text { IVU } \\
\text { DUA } \\
\text { Municipality }\end{array}$ \\
\hline Public health & $\begin{array}{l}\text { DIGAMS } \\
\text { Municipality }\end{array}$ & MSP \\
\hline Community development & DINADECO & $\begin{array}{l}\text { Municipality } \\
\text { FOCCO }\end{array}$ \\
\hline Planning & $\begin{array}{l}\text { OFIPLAN } \\
\text { Municipality }\end{array}$ & $\begin{array}{l}\text { DUA } \\
\text { CONAPLAN }\end{array}$ \\
\hline Markets & Municipality & $\begin{array}{l}\text { Municipality } \\
\text { MOPT }\end{array}$ \\
\hline Public housing & INVU & IVU \\
\hline
\end{tabular}

Abbreviations:

$\begin{array}{ll}\text { MPJG } & \text { Ministry of Police, Justice and Grace } \\ \text { CIN } & \text { Interinstitutional Commission on Nomenclature } \\ \text { MSP } & \text { Ministry of Public Health } \\ \text { MNJ } & \text { National Youth Movement } \\ \text { FOCCO } & \text { Office for Community Development and Self Help } \\ \text { DGD } & \text { Directorate General of Sports } \\ \text { DIGAMS } & \text { Directorate General for Medical and Social Assistance } \\ \text { OFIPLAN } & \text { Presidential planning office }\end{array}$

Figure 12. Agencies providing municipal services. 
permitted to. Another possible explanation is that many other municipalities a]so oppose some of the agencies in Costa Rica; few, if any, do openly in EI Salvador.

Some differences in the institutional settings of the agencies within the national government structure might also account for the difference. In Costa Rica these agencies are autonomous, not part of or subject to the control of any ministry. They are creatures of, have budgets approved by and are responsible to the Legislature. This gives them a great deal of internal administrative freedom. It also renders them subject to greater political pressures by legislators. And Costa Rican legislators are, in turn, subject to more political pressure from their constituents.

In El Salvador, on the other hand, these agencies are semiautonoliuus. Each is attached to a ministry of the central government. The agency must subordinate its aims and activities to the larger objectives of the ministry. The agency gains, however, the advantage of being a part of the national executive. It is insulated from any possible legislative political pressure and is responsible, through its minister, only to the president. And the President of El Salvador is much less susceptible to political pressure from his constituents than is the member of the Costa Rican Legislative Assembly.

One other peripheral but related difference may be noted here. A citizen, particularly one without political clout, who is unhappy with his water supply (most fit in this category) will approach his city councillor about it in San José. This is not the case in San Salvador. It is unclear whether the councillor in San José is ap- 
proached because prior to SNAA's formation in 1961 the municipality looked after its own water supply, or because the citizen perceives the councillor as more accessible than the SNAA bureaucracy, or if the councillor is viewed as actually being able to correct the situation.

To this point our discussion of the relationships between municipalities and the autonomous or semi-autonomous agencies has stressed the negative. In both countries, however, there exist agencies specifically designed to assist the municipalities. In El Salvador this agency, attached to the Ministry of the Interior, is the Municipal De17

velopment Bank (FINAMUN), and in Costa Rica it is the Institute for Municipal Development and Assistance (IFAM) .

The Municipal Development Bank was set up by the Legislature in 1966 and was assigned as its functions:

a) To make loans to the Municipalities in order that they be able to realize their works and services

b) To give technical assistance to the Municipalities when this is necessary, being able to recommend sound financial and administrative practices in the following cases

1) In the programming, budgeting, financing, and construction of municipal public works and services

2) In the improvement of the internal administrative organization and systems for collecting, accounting, auditing and financial administration, in order to obtain an increase in municipal income

3) In whatever other type of technical assistance that the Bank can provide through its nature and aims and which does not contravene the provisions of this law. 18

Eight years later, however, in 1974, there was still no sign of any financing. The explanation offered by the municipalities was predictable--central government obstructionism. Critics claim the bank was set up so that only the four largest municipalities could possibly 
take advantage of it, and, further, that any municipality not having the official party (PCN) in power could forget about any assistance. There was a faint glimmer of optimism, however. Rumors abounded that FINAMUN was going to be, at long last, funded and staffed. Nonetheless, one Salvadorean municipal official was able to accurately complain:

To date there exists no institution charged with the mission of augmenting the financial resources of the Municipalities, much less of providing technical assistance. 19

The same cannot be said of Costa Rica, where IFAM, in existence since 1971, is taking definite, concrete steps to aid the municipalities. IFAM's two grand objectives are to 1) strengthen the municipal regime from a legal-political point of view, and 2) convert the municipalities into true enterprises of local and regional development. More pragmatically, IFAM makes loans to the municipalities and guarantees those they obtain elsewhere, conducts seminars for municipal officials both appointed and elected, serves as an instrument for inter-municipal cooperation, provides various forms of technical assistance, carries out feasibility studies and issues monographs on various topics of municipal interest. IFAM also coordinates the work of international experts assisting the municipalities. A typical case occurred when IFAM provided a small municipality with a Peace Corps Volunteer civil engineer to design and oversee the construction of a 21 local water system.

The governing board of IFAM is appointed by the Council of Gov22

ernment. Of the seven members, two must be the Minister of Government and the Minister of Public Works. Three must be chosen from a 
list provided by the political party whose candidate ran second in the preceding presidential election. In only two cases, then, does the Council have a free choice. There is no requirement that appointees have any municipal experience or affiliation to serve their four-year terms. IFAM has, however, been on the whole very well staffed.

The final point to be considered in re relations between local and national government is the partisan political factor. Here again the situation is very different in the two countries. In San Salvador, the city council is engaged in open political warfare with the national government. Since 1950 the official party (PRUD-PCN) has controlled both the National Assembly and the presidency; since 1961 it has been out of power in San Salvador.

Not only has the single-party municipal council been in partisan opposition to the national government, it has been the most powerful, perhaps the only, source of real opposition. Next to the presidency, the alcaldia of San Salvador is certainly the most visible and probably the most powerful political position in the country. The alcalde of the capital city is usually viewed as the single most likely opposition candidate in the next presidential election. Napoleon Duarte, for example, two-term PDC alcalde of San Salvador, did run for president against Arturo Molina in 1972. Duarte was implicated in a bloody abortive coup that followed his unsuccessful candidacy.

The situation is very different in Costa Rica where the president of the San José municipal council is virtually invisible, even in San José, and where the same spectrum of parties is to be found in the council are in the National Assembly. Consider the following table: 
TABLE I

SEATS HELD IN SAN JOSE AND COSTA RICA, BY PARTY

\begin{tabular}{|c|c|c|c|c|c|}
\hline Year & Party & $\mathrm{Nat}$ & Assemb1y & San José & Council \\
\hline & & Nun & Percent & Number & Percent \\
\hline & & of & & of seats & \\
\hline 1962 & PLN & 29 & 51 & 5 & 45 \\
\hline & PUN & 9 & 16 & 1 & 10 \\
\hline & PRN & 18 & 32 & 5 & 45 \\
\hline & $\mathrm{AD}$ & 1 & 2 & & \\
\hline 1966 & PLN & 29 & 51 & 5 & 42 \\
\hline & PUN & 26 & 46 & 2 & 17 \\
\hline & PRN & & & 4 & 33 \\
\hline & PUCR & 2 & 4 & 1 & 8 \\
\hline 1970 & PLN & 32 & 56 & 6 & 55 \\
\hline & PUN & 22 & 39 & 4 & 36 \\
\hline & PASO & 2 & 4 & 1 & 10 \\
\hline & $C D$ & 1 & 2 & & \\
\hline 1974 & PLN & 25 & 44 & 5 & 38 \\
\hline & PUN & 17 & 30 & 3 & 23 \\
\hline & PASO & 1 & 2 & 1 & 8 \\
\hline & PRD & 4 & 7 & 2 & 15 \\
\hline & PRN & 1 & 2 & 1 & 8 \\
\hline & PNI & 7 & 12 & 1 & 8 \\
\hline & PUAC & 1 & 2 & & \\
\hline & $\mathrm{PD}$ & 7 & 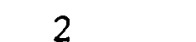 & & \\
\hline
\end{tabular}

SOURCE: Costa Rica, Tribuna Suprema de Elecciones, Computo de Votos. (1972, 1966, 1970 and 1974 issues).

It can be readily seen that in every case the PLN held the largest number of seats in both the assembly and the council. Moreover, in every case except the period 1966 to 1970 , the party having the second largest representation in the assembly also had the second largest representation on the council. It was anticipated, therefore, that municipal tax legislation, especialiy when passed unanimously, would have much less difficulty being approved by the national government than in El Salvador. It was expected this would be a major dif- 
ference in the policy process between the two polities. There turned out to be no difference at all in the legislative assemblies' actions; tax increases were routinely denied to both San Salvador and San José.

$\underline{\text { Parties And Elections }}$

As shown above, parties and elections play a major role in determining control of the municipal governments in both San José and San Salvador. However, there are substantial differences between the practices of the two cities. We consider first the nature of the parties and then of the electoral process.

Both El Salvador and Costa Rica have a broad spectrum of parties operating at the municipal level. However, those in San Salvador are far more ideological and less personalistic than those in Costa Rica. This is particularly true of the Salvadorean PDC. It offers the voters a detailed platform of mutually supportive planks all based in the tenets of Christian Democracy as found in many Latin American countries. Its pre-election appeals to the electorate are couched in terms of this Christian Democratic philosophy. Primarily, it emphasizes the role of the community in the nation state and two sets of policy offerings. To the small urban middle class it offers administrative reform and expanded municipal services. To the mass of the urban poor and near poor it offers a chance to participate in the political life of the city through neighborhood action programs, primarily under the auspices of the local offices of the Department of Community Action.

The PCN, the official party, does not go into such detail. It 
emphasizes the integrity of its candidates, and alludes to the benefits the urban dwellers will realize in having their city governed by the party in power nationally. As the central governing party, it places much less emphasis on the city. PCN's primary loyalties are to maintenance of the status quo, economic development, and 'Los Catorces Grandes,' the fourteen extended families who are said to control the Sal vadorean economy.

These two parties occupy the broad center of the political spectrum in El Salvador: PDC on the center-1eft and PCN on the centerright. To the left of the PDC is the National Revolutionary Movement (MNR) . To the right of the PCN are the Salvadorean Popular Party (PPS) and the United Democratic Independent Front (FUDI). The latter is primarily an ad hoc vehicle for the personal political ambition of General José Alberto 'Chele' Medrano. Medrano was dismissed from his post as Chief of the National Guard and from the official party as a political liability; he was identified in the public mind with an apparent policy of occasional police murders in the late 1960s. FUDI is the only recognized political party that is totally personalistic.

One more party might be mentioned, the Democratic Nationalist Union (UDN). It occupied a reformist position between MNR and PDC. Primarily, it was the party of the intellectuals. In the 1972 election it banded together with MNR and PDC to form an United Opposition Front (UNO). In 1972 and subsequent municipal elections it has been UNO that has challenged the other parties--PCN, PPS, FUDI--at the polls. The PDC dominates this coalition, MNR maintains its identity except at election time, but UDN does not seem to have survived the 
merger with its larger erstwhile partners.

As indicated above in Table I, from four to eight parties generally contest municipal elections in San José. ${ }^{23}$ Currently six parties are represented on the municipal council. While these parties are more personalistic than, and do not fit into ideological slots as neatly as, Salvadorean parties, some identification as to their broad general viewpoints may be attempted. From left to right, then, these parties may be generally arrayed thus. Indisputedly anchoring the left wing is the Socialist Action Party (PASO). In Western Europe PASO would be known as the Communist Party, but the Communist Party is illegal in Costa Rica. No party currently fills the generic social democratic slot on the moderate left. In left center, the PLN occupies the same Christian Democratic position as PDC in San Salvador. The National Unification Party (PUN) is roughly in the center and the Party of Democratic Renovation (PRD), a business-oriented group espousing efficient administration over all else, is slightly to the right. The National Republican Party (PNR) and National Independence Party (PNI) occupy the same sort of ideological territory on the moderate right.

It has been noted that the parties in San José are not as ideologically distinguishable as are those in San Salvador--this does not mean their adherents' sense of party identification is any weaker. The voters in an election determine the number of seats each party will have, but the party has ranked its candidates on the ballot, essentially determining in what order individuals will fill the seats it wins. Choice of an individual councillor is, therefore, effectively 
out of the hands of the electorate but the voters do have the choice of party. The voters lack the opportunity to support an individual for a particular office. Such empathy as the voter feels, then, is with the party and not with any one candidate. The party is the entity for which votes are cast.

In both cities the party composition of the governing body is determined by elections. In each case the electorate includes all residents of the municipality over 18 years of age who are citizens of their respective countries. There is no voter registration procedure--citizens are automatically added to the voting rolls when they obtain, at age eighteen, their cedulas--the ubiquitous identity cards without which one has no civil status.

Elections are governed by electoral boards which oversee all aspects including registration of parties, campaign practices and vote counting. Initial rulings and judgments are made by the municipal juntas; they can be overruled by the central boards which appoint them. The Costa Rican ultimate authority in electoral matters is the Supreme Election Tribunal (TSE). The three members of this tribunal, expanded to five during election years, are Justices of the Supreme Court. They are universally regarded as being as free from corruption and partisan political pressure as is humanly possible.

No such kudos are directed to the Salvadorean Central Electoral Council (CCE). Its members are selected by the National Assembly. CCE is allegedly independent and unbiased but is generally believed to be yet another arm of the official party.

To participate in an election, national or municipal, in Costa 
Rica or El Salvador, political parties must be registered with the appropriate electoral board. Not only the party itself must be approved but also its slate of candidates for a particular office. Slates for municipal offices may be rejected by local juntas; this decision may be appealed to the central authority. In fact, most claims of fraud-and they are legion--leveled in connection with Salvadorean municipal elections involve alleged improper disqualification of slates of candidates. Slates are generally disqualified for one of two reasons; either the slate was improperly selected or one or more individual candidates may be ruled ineligible for the position sought. In the latter case, in Costa Rica, the offending candidate may be replaced and the slate reinstated; no such second chance is usually available in E1 Salvador.

Party slates serve quite different purposes in the two cities. In El Salvador slates are offered to the voters on an all-or-nothing, takes-us-or-leave-us basis. The party winning the greatest number of votes in the municipal election wins all the offices: mayor, legal officer and 100 percent of the councillors.

By contrast, in Costa Rica the slate is an indication to the voters of the order in which the party's seats on the municipal council will be filled. (Elections to the National Assembly are carried out the same way; each party has a slate of candidates in each province.) The order of appearance of the candidates on the ballots, then, is not a matter of chance but of party preference. The individual on top of the party's list of candidates is the most important, the one on the bottom the most expendable. 
Elections in Costa Rica, both municipal and national, are carried out under the quotient or modified d'Hondt system of proportional re24 presentation. This system is explained in more detail below, Appen$\operatorname{dix}$ C. For present purposes, however, two significant political results of this system need be mentioned. First, like most proportional representation systems, it favors small minority parties. Second, it makes position on the party's slate very important to the individual candidate. The election determines how many of a party's candidates are elected but position on the ballot determines which candidates. If the party wins two seats, they are filled by the first two persons listed on the ballot.

Selection of candidates is a very important matter, and very different concerns are involved in the two polities. In San Salvador, the candidate for mayor is chosen by a national party caucus. The rest of the slate is chosen by the candidate for mayor in consultation with local and national party leaders. Disaffected members of all parties save the PCN often claim that meetings for this purpose occur at a time and place different than that announced, for the purpose of allowing a small cabal rather than the general party leadership to choose the candidates. Needless to say, the official party is quick to publicize this lack of candor and unity on the part of its opposition. Balancing the municipal ticket is regarded as critical. Each party selects a couple of women, a smattering of professionals-lawyers, physicians, dentists--and representatives from 1 abor, education and the small merchant class. Every effort is made to promote these candidates as individuals and as advocates of the interests of 
a specific group.

Candidates for municipal office in San José are chosen by the party faithful of the canton with the advice and consent of the national party leadership. Unlike San Salvador, little attempt is made to promote the candidates as individuals. The one personality actively publicized by the party is its presidential candidate. Candidates for municipal office, then, are neither seen as individuals nor as representatives of certain groups or interests, but as members of the party. Consequently no attempt whatever is made to balance the ticket occupationally. Almost as critical as the selection of candidates for the slate is their positioning thereon. The top candidate of virtually any party is assured a seat; the bottom candidates of even an overwhelming majority party are unlikely to be selected. Candidates who accept the limbo of a low position on the ticket in one election are usually rewarded by being moved up in a subsequent election, as those above them move on to seek national office. New candidates for the bottom slots are then chosen, generally from those who have served as alternates or neighborhood representatives.

Open campaigning for office usually begins about two months before the election. It will be remembered that in Costa Rica presidential, legislative and municipal elections are held concurrently while in El Salvador presidential elections are separated. Partly as a result of this campaign styles differ markedly. In Costa Rica emphasis is upon the presidential candidate and the party. City council hopefuls and even candidates for the National Assembly to some extent are 
just along for the ride. Explicit platforms or policy statements are few. If enunciated, they come from the mouths of the presidential candidates.

Each party has its banner, its own distinctive colors. These are plastered about the country. Massive advertising blitzes are carried on via the newspapers and on radio. The heart of the campaign, nowever, is the parade. These parades occur with greater and greater frequency as the election nears. During the last two weeks they are daily events. The general aura ranges from chaos in small towns and villages to pandemonium in San José. Not only does each party have its own colors, it also has its own distinctive automobile horn sound. A typical evening in San José shortly before the election finds several caravans of party adherents each honking out the party signal or waving the party banner as they surge through narrow downtown streets. To the foreigner it seems as though the contest is between the beeepbeeeep-beeeps and the be-be-be-beep-beeps. Issues are not allowed to intrude.

Styles are much different in San Salvador. UNO, dominated by PDC, publishes and distributes carefully thought out and prepared leaflets laying out past accomplishments of the municipal government and outlining its future plans. The background and competence of each candidate for office is explained. There are no continuous parades analagous to those in San José but occasionally well-publicized mass rallies are held. PPS activities generally parallel those of UNO but are more subdued, while PCN festoons the streets with banners proclaiming their candidates to be men of integrity. 
Relationships among parties are quite dissimilar in San Salvador and San Jose. In Costa Rica parties virtually ignore one another's existence and campaign as in a vacuum--only if some faux pas leaves the party holding the presidency momentarily open to criticism or embarrassment will one party refer or allude to another. Salvadorean parties on the other hand constantly compare programs and candidates, position for position. As soon as the members of the oppositions' slates are known, the parties attempt to discredit them personally and professionally. Advertisements appear regularly in the San Salvador dailies, paid for by Party $X$, alleging that Party Y's labor-affiliated candidate for councillor sold out the workers to some malevolent entity in exchange for personal enrichment. As election day nears the attacks grow more vitriolic. By the last week the tone of the campaign can turn outright nasty. One party rushes into print with documentation showing another party's candidate to be a bastard. This party responds with material of its own and says in effect, "Our man may be a bastard but at least he's a Salvadorean bastard. Your man is a Honduran bastard, and moreover, a Honduran bastard with forged papers."

Eventually the campaign comes to an end, the election is held and the municipal council takes office. Questions are often raised as to the openness and honesty of Salvadorean elections. Most of these doubts, however, relate primarily to the presidential election. UNOPDC, in opposition to the official party, has been in power in San Salvador for over 15 years. No such doubts as to freedom or honesty plague the Costa Rican elections. At all levels they are among 
the most fairly conducted in the world. On the other side of the coin, they are also probably the world's most expensive elections. Expenditures per vote cast are estimated to be three times the cost per vote in the United States.

Methods of candidate selection, campaign strategies, rhetoric and voting procedures may seem strange, perhaps even suspect, to North American observers. Nonetheless, it is popular elections, contested by recognizable political parties, that determine control of the machinery of municipal government in both San Salvador and San José.

\section{Non-governmental Actors}

Among the basic assumptions of most models of the policy process is the supposition that policy is made, at least within the boundaries of the political system, by formal policymakers. In San José and San Salvador, as in many other polities, additional, informal actors may be found playing roles not formally ascribed them. In a subsequent section dealing with muncipal public finance policy we will look at some specific sorts of informal actors; it will suffice here to look at such actors generally, their points of access to the policy process and the causes and effects of their intervention.

Outsiders attempting to influence the policy process usually do so at the legitimation phase, for a variety of very good reasons. Actors who feel themselves potent enough to influence the course of legislation usually wish to preserve the status quo, to prevent the municipality making some change such as raising a tax rate. Generally, such outside actors do not first press their case with the municipality. Often they first hear of this legislation they feel will ad- 
versely affect them after it has passed and become fait accompli as far as the municipal council is concerned. As a consequence, the affected individual or group has no other recourse but to try and dissuade the central authorities from approving the unwanted ordinance. A number of factors make this approach quite convenient. Both San José and San Salvador are capital cities. As such, members of the legislative assembly, cabinet ministers and other high national government officials are close at hand. Moreover, those seeking to block the legitimation of the municipal legislation are usually 'community influentials,' used to dealing with upper-echelon national government officials and in many cases are personally or professionally acquainted with them. Central government officials are also easier to locate than municipal officials, being both more readily identified and more likely to be in or about their offices.

One reason national legislators are often inclined to disallow municipal legislation, especially tax bills, is that political costs to them are likely to be less than the political benefits. They can appear to the voters as fiscally responsible, always an attractive posture. A municipal councillor has to balance any anti-tax position with the demands of the canton's voters, or their leaders, for increased spending on municipal services. Opposition to such demands could lead to a councillor's being dropped by the party at the next election, if the party perceived this opposition as likely to cost it votes. A Member of the Assembly, with a province-wide constituency, would obviously be under less direct and less one-sided pressure, even were he elected from San Josē Province. A legislator from an outlying 
corner of the country would be viewed positively as standing up to the profligate capital's attempt to raise taxes, some portion of which would ultimately be paid by his constituents but which they would view as benefiting only the capital city residents.

Pursuing the capital city syndrome further, certain acts of the capital municipality could be regarded as matters of national or even international concern. Capital cities are usually the locales for home offices of national corporations and country headquarters of multinational corporations. Should municipal actions negatively impact on these corporate heartlands, the case for national counteraction would be buttressed.

The outright animosity between municipal and central governments in San Salvador may be mentioned again. Often the mere fact that the Municipality of San Salvador has passed an ordinance, particularly a tax ordinance, is sufficient reason for the central government to consider vetoing it. Adversely affected members of the business community in particular are well aware of this and do not hesitate to argue their position, usually with some success, before the Minister of the Interior and, if necessary, the assembly.

Outside actors attempt to influence the policy process, then, in both cities. Usually the method of choice is the seeking of national government intervention at the legitimation stage. These informal policy participants are usually community influentials, and are usually successful. Animosity between city and nation in El Salvador exacerbates the situation there but any resultant differences between San José and San Salvador in this respect are differences of degree 
and not of kind.

\section{Policy Preferences of Local Government Leaders}

The final political factor to be considered here is the role of, or weight given to, the policy preferences of local government leaders. Once again major differences exist in this field between San Salvador and San José.

To a large extent, the elected officials take over the reins of municipal government in San Salvador with very few strings attached. To be sure, the party, particularly PDC-UNO, has indicated to the citizenry during the campaign where it stands and what it intends to do. These pledges, however, like campaign promises everywhere, are both flexible and negotiable.

In the political wings the national government is indeed waiting to disallow such legislation as it feels appropriate. But despite the animosity between central and city governments, not all ordinances or accords are vetoed on partisan or other grounds. The municipality simply deals with too many mundane and prosaic matters for the nation to be concerned with them all. Even the most ardent supporters of central control allow that a great deal of municipal activity cannot possibly be regarded as nationwide in its effects.

There exists, morecuer, no externally imposed national party line to which the PDC-UNO council must adhere. El Salvador is a small country; San Salvador is the capital city and the chief source of PDC political power, nationaliy as well as locally. The local power structure, it has been shown, is inextricably linked to and a part, a dominant part, of the national party hierarchy. Not only, then, is 
there no intraparty cleavage but it is recognized that the municipality provides the best showcase for party policies, a showcase that might someday induce the voters to choose PDC nationally.

The policy preferences of local government leaders in San Salvador are thus readily and routinely translated into policy outputs of the one-party municipal council. And, it must be remembered, the two most important administrative posts are filled by elected party members. Except for those accords, generally tax related, that are disallowed by the national government, the policy preferences of the municipal government leaders become the operational policies of the Municipality of San Salvador.

Policy preferences of local government leaders in San José are given no such respect. They are not ignored, but neither are they automatically transmuted into legislation let alone into practice. One reason for this is the difference in the party situation. Actually there are two important differences in the party situation. One of these is the presence, as we have seen above, of several political parties in the San José municipal council, a very different case from the Salvadorean. Second, the local government leadership does not constitute, although it is not necessarily excluded from, the national party leadership. This is particularly so for the party controlling the presidency or the national assembly.

Further, there is a partnership with the usual shackles between local and national government in Costa Rica that is unknown in El Salvador. The national government issues policy statements on local matters. It is not only politically but fiscally prudent for local gov- 
ernment to heed these, even to the point of suppressing its own policy preferences. Perhaps most important, the central govermment provides considerable financial assistance to local government. Much of this is statutorily mandated and not subject to curtailment for heterodoxy in policy aims but the remainder is discretionary--amounts are to be allocated to municipalities but particular municipalities are nowhere specified. The central government therefore, buys an arena for its policy preferences and those of local leaders are often reduced to secondary considerations.

Finally, the municipal council in San José is obligated to not only hear but also to give some cognizance to the policy preferences of the neighborhood representatives. It will be remembered that monies raised in a neighborhood are to be spent in that same neighborhood regardiess of other priorities council may have. Policy preferences of municipal government officials, then, are diluted by edicts and money from above as well as by narrow submunicipal interests from below.

It can be seen, then, that the status accorded the policy preferences of local government leaders varies greatly between San José and San Salvador. And this is only one of the political factors exhibiting this variance. Others have been analyzed above. It remains to be seen how these differences, when combined with any differences noted below in economic and social factor, influence policy process and policy product. Do the differences we have examined, in fact, manifest themselves in any important policy effects? 


\section{ECONOMIC FACTORS}

Economic background factors, like the political factors mentioned above, are traditionally, and rationally, regarded as affecting policy. The factors to be considered here are economic structure, 1abor force composition and unemployment, public-private mix, distributional aspects, and national revenue and expenditure patterns.

\section{$\underline{\text { Economic Structure }}$}

The measure chosen for economic structure is the Gross Domestic Product (GDP). (For comparative purposes all figures are given in Central American Pesos. $\$ 1.00$ U.S. $=\$ 1.00 \mathrm{C.A.})^{28}$ The makeup of the GDP at current prices, for the six years immediately preceding this study, is given in Table II.

\section{TABLE II}

STRUCTURE OF GROSS DOMESTIC PRODUCT AT CURRENT PRICES

Agriculture

Manufacturing

Construction

Electricity

Transportation

Commerce

Finance

Rents

Government

Services

Total
Costa Rica $(000,000$ \$C.A.)

\begin{tabular}{rrrrrr}
1967 & 1968 & 1969 & 1970 & 1971 & \multicolumn{1}{c}{1972} \\
165.0 & 181.9 & 209.8 & 218.7 & 230.5 & 252.4 \\
132.0 & 148.1 & 162.5 & 182.9 & 202.3 & 226.6 \\
30.0 & 34.7 & 35.7 & 42.8 & 54.6 & 60.4 \\
10.5 & 12.1 & 15.0 & 16.2 & 19.2 & 21.8 \\
27.8 & 30.8 & 35.9 & 38.1 & 43.9 & 48.6 \\
108.3 & 119.1 & 131.6 & 157.7 & 175.3 & 195.4 \\
19.9 & 22.9 & 27.5 & 32.4 & 35.6 & 41.7 \\
55.5 & 58.0 & 60.6 & 63.9 & 67.0 & 71.3 \\
74.3 & 81.2 & 92.5 & 103.0 & 121.9 & 140.5 \\
70.8 & 75.4 & 82.9 & 91.2 & 98.5 & 108.5
\end{tabular}

$\begin{array}{llllll}694.2 & 764.4 & 854.1 & 947.0 & 1048.9 & 1167.2\end{array}$


TABLE II--Continued.

E1 Salvador $(000,000 \$ C . A$.

$\begin{array}{lrrrrrr} & 1967 & 1968 & 1969 & 1970 & 1971 & 1972 \\ \text { Agriculture } & 240.0 & 241.1 & 242.8 & 292.5 & 291.6 & 291.2 \\ \text { Manufacturing } & 170.3 & 180.4 & 187.9 & 195.6 & 209.4 & 226.8 \\ \text { Construction } & 27.3 & 22.7 & 27.0 & 28.9 & 32.0 & 40.8 \\ \text { Electricity } & 12.6 & 14.0 & 14.4 & 15.5 & 16.1 & 17.2 \\ \text { Transportation } & 39.1 & 45.5 & 49.2 & 49.1 & 52.6 & 55.8 \\ \text { Commerce } & 211.2 & 215.9 & 216.2 & 217.4 & 234.8 & 257.5 \\ \text { Finance } & 16.9 & 18.4 & 20.5 & 23.0 & 24.8 & 26.2 \\ \text { Rents } & 34.3 & 36.1 & 37.3 & 38.0 & 44.0 & 42.8 \\ \text { Government } & 67.0 & 68.0 & 76.2 & 80.1 & 87.6 & 95.4 \\ \text { Services } & 67.7 & 74.6 & 80.6 & 86.2 & 92.3 & 98.9\end{array}$

Total

$\begin{array}{llllll}879.0 & 909.5 & 944.7 & 1020.1 & 1071.5 & 1142.1\end{array}$

SOURCES: Banco Central de Costa Rica; Banco Central de Reserva de El Salvador.

Two factors are immediately evident--the economies of the two countries are very similar in size, and in 1972, for the first time, the GDP of Costa Rica exceeded that of El Salvador.

Table III gives the percentage composition of the GDP for each country over the same time span. Again, the similarities between the two are apparent. In both cases agriculture dominates and manufacturing accounts for about one-fifth of the total. Commerce is relatively more important in E1 Salvador than in Costa Rica, but only slightly; the reverse holds true for rental income. In neither case has there been any significant shift in importance of the various sectors during the six-year period.

In Table IV the structure of the GDP is again presented, but in constant (1962) pesos. One important difference from the current price situation appears--the total Salvadorean economy is larger every year 
than the Costa Rican. The latter nation has obviously been subject to a higher rate of inflation.

TABLE III

PERCENTAGE COMPOSITION OF GROSS DOMESTIC PRODUCT BY INDUSTRIAL SECTOR Costa Rica

$\begin{array}{lrrrrrr} & 1967 & 1968 & 1969 & 1970 & 1971 & 1972 \\ \text { Agriculture } & 23.8 & 23.8 & 24.6 & 23.1 & 22.0 & 21.6 \\ \text { Manufacturing } & 19.0 & 19.4 & 19.0 & 19.3 & 19.3 & 19.4 \\ \text { Construction } & 4.3 & 4.5 & 4.2 & 4.5 & 5.2 & 5.2 \\ \text { Electricity } & 1.5 & 1.6 & 1.8 & 1.7 & 1.8 & 1.9 \\ \text { Transportation } & 4.0 & 4.0 & 4.2 & 4.0 & 4.2 & 4.2 \\ \text { Commerce } & 15.6 & 15.6 & 15.4 & 16.7 & 16.7 & 16.7 \\ \text { Finance } & 2.9 & 3.0 & 3.2 & 3.4 & 3.4 & 3.6 \\ \text { Rents } & 8.0 & 7.6 & 7.1 & 6.8 & 6.4 & 6.1 \\ \text { Government } & 10.7 & 10.6 & 10.8 & 10.9 & 11.6 & 12.0 \\ \text { Services } & 10.2 & 9.0 & 9.7 & 9.6 & 9.4 & 9.3\end{array}$

\section{EI Salvador}

$\begin{array}{lrrrrrr}\text { Agriculture } & 27.1 & 26.3 & 25.5 & 28.4 & 26.9 & 25.3 \\ \text { Manufacturing } & 19.9 & 19.7 & 19.7 & 19.1 & 19.4 & 19.7 \\ \text { Construction } & 3.1 & 2.5 & 2.8 & 2.8 & 3.0 & 3.5 \\ \text { Electricity } & 1.4 & 1.5 & 1.5 & 1.5 & 1.5 & 1.5 \\ \text { Transportation } & 4.4 & 5.0 & 5.2 & 5.0 & 4.9 & 4.8 \\ \text { Commerce } & 23.8 & 23.6 & 22.7 & 21.1 & 21.7 & 22.3 \\ \text { Finance } & 1.9 & 2.0 & 2.2 & 2.2 & 2.3 & 2.3 \\ \text { Rents } & 3.9 & 3.9 & 3.9 & 3.7 & 3.7 & 3.7 \\ \text { Government } & 7.5 & 7.4 & 8.0 & 7.8 & 8.1 & 8.3 \\ \text { Services } & 7.6 & 8.1 & 8.5 & 8.4 & 8.5 & 8.6\end{array}$

Table $\mathrm{V}$ presents the year-to-year growth of the GDP, both at current prices and, more imformatively, in constant 1962 pesos. Using current prices, the Costa Rican GDP is seen to grow considerably faster than that of E1 Salvador. When inflation is accounted for, Costa Rica still has the faster growing economy but the differences are not so marked. 
TABLE IV

STRUCTURE OF GROSS DOMESTIC PRODUCT AT FIXED (1962) PRICES

$(000,000$ \$C.A.)

Costa Rica

$\begin{array}{lrrrrrr} & 1967 & 1968 & 1969 & 1970 & 1971 & 1972 \\ \text { Agriculture } & 158.7 & 168.2 & 188.9 & 188.1 & 192.4 & 201.3 \\ \text { Manufacturing } & 126.9 & 136.9 & 146.3 & 157.3 & 168.9 & 180.8 \\ \text { Construction } & 28.9 & 32.1 & 32.1 & 36.8 & 45.6 & 48.2 \\ \text { Electricity } & 10.1 & 11.2 & 13.5 & 13.9 & 16.0 & 17.4 \\ \text { Transportation } & 26.7 & 28.5 & 32.3 & 32.8 & 36.6 & 38.8 \\ \text { Commerce } & 104.2 & 110.1 & 118.5 & 135.7 & 146.4 & 155.9 \\ \text { Finance } & 19.1 & 21.2 & 24.8 & 27.9 & 29.7 & 33.3 \\ \text { Rents } & 53.4 & 53.6 & 54.6 & 55.0 & 55.9 & 56.9 \\ \text { Government } & 71.5 & 75.1 & 83.3 & 88.6 & 101.8 & 112.1 \\ \text { Services } & 68.1 & 69.7 & 74.6 & 78.5 & 82.2 & 86.6 \\ & & & & & & \\ & & & & & & \\ \end{array}$

E1 Salvador

$\begin{array}{lrrrrrr}\text { Agriculture } & 223.1 & 227.1 & 235.4 & 250.9 & 260.3 & 264.1 \\ \text { Manufacturing } & 162.0 & 168.9 & 170.2 & 176.8 & 189.0 & 196.3 \\ \text { Construction } & 27.0 & 22.7 & 25.6 & 25.5 & 28.2 & 37.5 \\ \text { Electricity } & 14.2 & 16.1 & 16.6 & 18.0 & 19.6 & 21.8 \\ \text { Transportation } & 41.0 & 46.4 & 47.6 & 51.2 & 51.8 & 54.4 \\ \text { Comnerce } & 225.3 & 232.8 & 232.8 & 226.2 & 230.4 & 245.4 \\ \text { Finance } & 16.2 & 17.6 & 19.6 & 20.4 & 20.8 & 23.9 \\ \text { Rents } & 32.6 & 33.7 & 34.9 & 36.2 & 37.2 & 39.8 \\ \text { Government } & 64.3 & 63.8 & 71.6 & 73.2 & 79.8 & 85.4 \\ \text { Services } & 64.5 & 69.4 & 75.1 & 79.2 & 84.6 & 89.7\end{array}$

Total

$\begin{array}{llllll}870.3 & 898.4 & 929.8 & 957.4 & 1001.7 & 1058.4\end{array}$

SOURCES: Banco Central de Costa Rica; Banco Central de Reserva de El Salvador.

One other point of comparison between the economies may be men-

tioned here. UNICEF has divided the economies of the Latin American 29

countries into six levels of development. In the lowest level, 
along with Haiti, the Dominican Republic and Honduras, they have placed El Salvador. In the second highest level they have placed Costa Rica, along side of Cuba, Panama, and Venezuela and surpassed only by Argentina, Chile, and Uruguay.

\section{TABLE V}

PERCENTAGE CHANGE IN GDP

Current Prices

Costa Rica El Salvador

$1967-68$

$1968-69$

$1969-70$

$1970-71$

$1971-72$

1967-72

Average

5.0

3.9

8.0

5.2

6.6

35.6

6.1

11.3
3.2

6.6

3.4

6.0

3.0

7.5

4.6

6.3

5.7

39.5

21.6

3.6

Labor Force And Unemployment

Labor force and unemployment data present another important aspect of a nation's economy. Unfortunately for analytical purposes, data on employment are neither as detailed nor as reliable as data on GDP. Nonetheless, Table VI indicates the labor force composition and unemployment rates for the two nations and their capital areas.

In making comparisons on the basis of these figures, their shortcomings and 1 imitations must be taken into account. Among other factors complicating a comparative analysis are two major ones: 1) the figures for San José are for the urban area of San José Province while 
those for San Salvador are for the Metropolitan Area; in both cases this is the statistical reporting unit most closely approximating the municipality, and 2) in Costa Rica the economically active population is calculated from the population twelve years and over while in E1 Salvador the minimum age to be counted is ten.

TABLE VI

AVERAGE LABOR FORCE BY INDUSTRIAL SECTOR, AND UNEMPLOYMENT, 1972 (\%) Costa Rica El Salvador San José San Salvador

$\begin{array}{lrrrr}\text { Agriculture } & 37.1 & 45.6 & 4.5 & 3.4 \\ \text { Manufacturing } & 11.9 & 8.3 & 19.3 & 18.3 \\ \text { Construction } & 6.4 & 2.1 & 7.2 & 5.5 \\ \text { Electricity } & 0.8 & 0.3 & 1.6 & 0.6 \\ \text { Transportation } & 4.0 & 2.6 & 5.1 & 5.3 \\ \text { Commerce } & 10.8 & 7.4 & 17.8 & 17.2 \\ \text { Finance } & 2.6 & 0.7 & 5.6 & 3.1 \\ \text { Service } & 21.3 & 13.1 & 35.3 & 35.1 \\ \text { Other } & 5.0 & 19.5 & 3.7 & 11.4\end{array}$

Tota 1

$\begin{array}{llll}100.0 & 100.0 & 100.0 & 100.0\end{array}$

Economically Active Population

Economically Inactive Population

589,040

$(52 \%)$
154,750

( $52 \%)$
342,028

$(61 \%)$

Total

$$
1,141,740 \quad 2,852,045 \quad 300,200 \quad 560,504
$$

Unemployed

Number

Rate

$\begin{array}{rr}39,080 & 264,231 \\ 7.1 \% & 20.1 \%\end{array}$

$\begin{array}{rr}9,860 & 30,150 \\ 6.8 \% & 13.8 \%\end{array}$

SOURCES: Costa Rica Census of 1973; El Salvador, Dirección General de Estadística y Censos. 
With these caveats in mind some evident comparisons may be made. The economically inactive population exceeds the active population in all cases; the difference is considerably more pronounced in San Salvador. In Costa Rica as a whole, a greater portion of the labor force is engaged in manufacturing, commerce and services than in El Salvador while the latter leads in agricultural workers and those of unspecified or unknown occupation. It may also be readily seen that the urban area labor forces, unlike the national ones, resemble one another very closely.

Unemployment is much more serious in El Salvador than in Costa Rica with a rate almost three times as high for the nation and over twice as high for the capital area. It will also be noted that, in both cases, unemployment is lower in the metropolitan areas than in the rest of the country with the difference being far more marked in El Salvador.

Moreover, there are other factors not shown in the table and almost impossible to document. In both cases unemployment is definitely understated by developed-nations' standards and in both cases unemployment among those under age 20 is at least twice that for the total work force. Finally, in both countries the labor force is growing faster than job opportunities.

\section{Public-Private Mix}

Despite a tradition of expanded public service delivery in Costa Rica and the absence of such tradition in San Salvador, very little difference may be detected between the actual public-private mixes of the two national economies as shown in Table VII. 
TABLE VII

PERCENT COMPOSITION OF GDP BY SECTOR (PUBLIC-PRIVATE MIX)

Costa Rica

$\begin{array}{lllllll} & 1967 & 1968 & 1969 & 1970 & 1971 & 1972 \\ & & & & & & \\ \text { Percent Private } & 83.3 & 83.4 & 82.8 & 82.3 & 83.1 & 81.9 \\ \text { Percent Public } & 16.7 & 16.6 & 17.2 & 17.7 & 16.9 & 18.1\end{array}$

El Salvador

Percent Private

Percent Public
87.8

12.2
88.0

12.0
87.1

12.9
86.5

13.5
$86.1 \quad 84.9$

$13.9 \quad 15.1$

SOURCES: Banco Central de Costa Rica; El Salvador, CONAPLAN, Indicadores, 1974 .

It may be seen that in both countries there is slow but (with one exception) steady increase in the percentage of the GDP that is generated in the public sector. As defined here, the public sector activities include the central governments, autonomous and semiautonomous agencies, and local governments. Although the relative size of public sector participation is similar in both countries, the internal composition of the public sector is quite different, as will be shown below in the analyses of governmental expenditure patterns.

\section{Distributional Aspects}

Distributional aspects of the economy may be broadly interpreted as including two sorts of considerations--per capita and by economic class. Table VIII shows per capita GDP at both current and 1962 prices, and the year-to-year changes.

Two significant differences between Costa Rica and El Salvador are immediately apparent. Productivity, as measured by per capita GDP, is almost twice as high in Costa Rica as in El Salvador. More- 
over, the difference is becoming greater. Salvadorean productivity was virtually stagnant over the six-year period while the Costa Rican averaged more than three percent annual increase.

TABLE VIII

PER CAPITA GROSS DOMESTIC PRODUCT, AND CHANGES, 1967-1972

Current Prices (\$C.A.) Fixed (1962) Prices (\$C.A.)

Per Capita GDP

$\begin{array}{lrrrr} & \text { Costa Rica } & \text { E1 Salvador } & \text { Costa Rica } & \text { E1 Salvador } \\ 1967 & 436 & 285 & 419 & \\ 1968 & 468 & 285 & 432 & 280 \\ 1969 & 507 & 286 & 456 & 289 \\ 1970 & 545 & 299 & 469 & 278 \\ 1971 & 587 & 304 & 490 & 281 \\ 1972 & 633 & 313 & 505 & 287 \\ & & & & \\ 1967-1968 & 7.3 & \text { Annual Changes in Per Capita GDP } & \\ 1968-1969 & 8.3 & & & \\ 1969-1970 & 7.5 & --- & 3.1 & -0.3 \\ 1970-1971 & 7.7 & 0.3 & 5.6 & 0.3 \\ 1971-1972 & 7.8 & 4.5 & 2.9 & -0.7 \\ 1967-1972 & 45.2 & 1.7 & 4.5 & 1.1 \\ \text { Average } & 7.5 & 3.0 & 3.1 & 2.1 \\ & & 9.8 & 20.5 & 0.4\end{array}$

That per capita income figures show the same general pattern as per capita GDP is shown in Table IX.

TABLE IX

PER CAPITA INCOME, 1960 AND 1970

Current Prices (\$C.A.) Fixed (1962) Prices (\$C.A.)

Costa Rica El Salvador Costa Rica El Salvador

$\begin{array}{lllll}1960 & 364 & 230 & 381 & 257\end{array}$

$\begin{array}{lllll}1970 & 469 & 298 & 403 & 256\end{array}$

SOURCE: UNICEF, Las Sociedades Centroamericanas Actuales. 
Again, we find El Salvador stagnating in the decade 1960 to 1970 with the apparent growth totally eroded by inflation. Costa Rica, on the other hand, despite its higher rate of inflation, enjoyed an annual average gain of over two percent during this period.

Although the per capita income is both higher and increasing more rapidly in Costa Rica, it is no more evenly distributed there than in El Salvador. Table $X$ shows both distribution by income class and how this distribution varies between the argricultural and nonagricultural sectors.

\section{TABLE X}

INCOME DISTRIBUTION, BY INCOME CLASS, 1970

$\begin{array}{lllll}\text { Poorest } & \text { Next } & \text { Next } & \text { Next } & \text { Richest } \\ 20 \% & 30 \% & 30 \% & 15 \% & 5 \%\end{array}$

$\begin{array}{llllll}\text { Costa Rica } & 5.5 \% & 12.5 \% & 22.0 \% & 25.0 \% & 35.0 \% \\ \text { El Salvador } & 5.5 \% & 10.5 \% & 22.6 \% & 28.4 \% & 32.9 \%\end{array}$

Share of total income received by poorest and richest classes, 1970

Costa Rica El Salvador

Poorest $20 \%$ Richest $5 \% \quad$ Poorest $20 \%$ Richest $5 \%$

Nonagricul tural
Sector
$4.7 \%$
$25.5 \%$
$4.2 \%$
$22.7 \%$

Agricultural

Sector

$9.0 \%$

$42.5 \%$

$7.0 \%$

$39.5 \%$

SOURCE: UNICEF, Las Sociedades Centroamericanas Actuales.

The general figures by class are very similar for the two, with Costa Rica demonstrating a slightly greater concentration in the highest income group. In both countries income is much more concentrated in the agricultural than in the nonagricultural sector. These data would 
suggest the existence of a middle/lower middle class in the nonagricultural sector that is either absent or very small in the agricultural sector. By implication this would support the idea of the 'middle class' as an urban phenomenon.

Another measure of equality or inequality of income distribution is provided by the Gini index. Barbara Stallings calculated the income Gini for Costa Rica as 0.51 and for El Salvador as $0.522^{30}$ By this measure, then, no significant difference exists between the two countries. (The extreme cases for Latin America are Ecuador with 0.32 and Columbia with 0.62 ; the U.S. scores 0.40.) Gini indices of 1 and distribution for the two countries show Costa Rica with 0.78 and E1 Salvador with 0.83 . These figures jibe with our income distribution data showing wealth to be considerably more concentrated in the countryside than in the cities. (Again, for comparative purposes, the land Gini in the U.S. is estimated at 0.71 ; the extremes for Latin America are Mexico with 0.69 and Peru with 0.93.)

In summary, then, we see Costa Rica exhibiting a considerable and growing productivity and an average income advantage over E1 Salvador. But we note as well the income is similarly maldistributed in the two countries; in both, the poorest half of the population receives less than 20 percent of the income while the wealthiest fifth of the population garners some 60 percent of the total.

\section{National Government Revenue Patterns}

The revenue and expenditure patterns of national governments are of particular concern for a number of reasons. It is here that politics and economics most directly interface. It is here than political 
decisions are made about the allocation and distribution of a significant portion of the societies' economic resources. And it is these patterns that form the tableaux against which we will examine the actual creation of local government revenue policy.

All countries claiming some degree of adherence to a market system fill their public fisc with a mixture of direct taxes, indirect taxes, and non-tax charges. Costa Rica and El Salvador are no exceptions. Most also engage in some sort of borrowing, but borrowing will not be considered in this particular section. Our concentration will be upon current income. Capital investments depend to a large extent on internal or external borrowing. They are sporadic, showing wide year-to-year variations. Borrowing, particularly external borrowing, is uncertain. The actual pattern of general government revenue is likely to be distorted by these occasional influxes of special purpose money. As a topic of analysis, then, and as an indicator of the overal1 government mindset on revenue raising, current income is a more useful measure than total income.

Tax structures in both Costa Rica and El Salvador are incredibly complex. To consider their minutae in this paper would be both inappropriate and unjustifiable in terms of time and effort. A general picture of the current income structure of the Costa Rican national government is presented in Table XI along with some indication of changes in the five years immediately preceding this study. Parallel information for El Salvador is provided in Table XII.

Before comparing the separate countries over time, and one with the other contemporaneously, we will briefly describe what sorts of 
TABLE XI

COSTA RICA NATIONAL GOVERNMENT INCOME, 1967 AND 1972

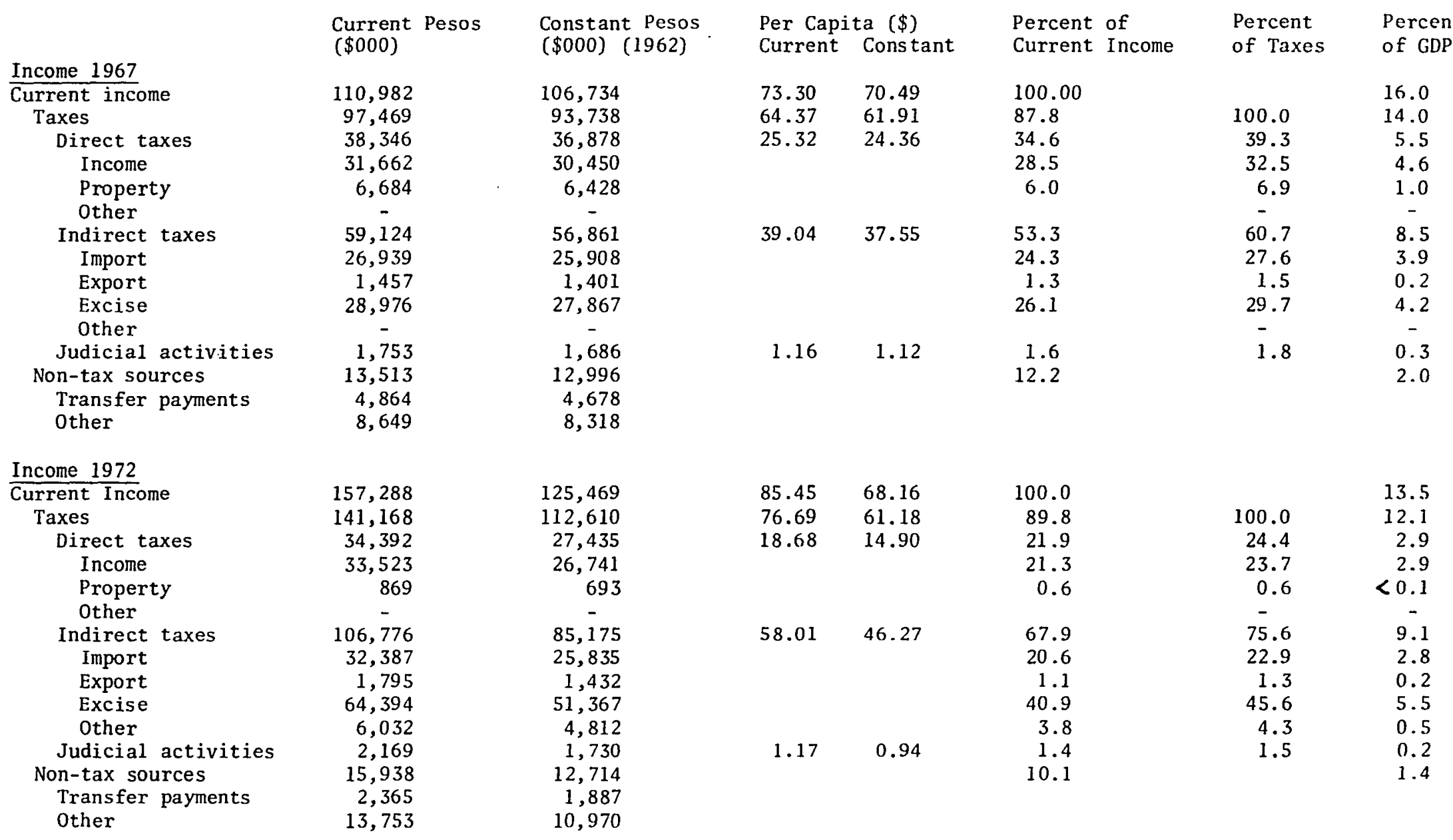


TABLE XII

EL SALVADOR NATIONAL GOVERNMENT INCOME, 1967 AND 1972

\begin{tabular}{l} 
Income 1967 \\
\hline Current income \\
Taxes \\
Direct taxes \\
Income \\
Property \\
Other \\
Indirect taxes \\
Import \\
Export \\
Excise \\
Other \\
Judicial activities \\
Non-tax sources \\
Transfer payments \\
Other \\
Income 1972 \\
\hline Current income \\
Taxes \\
Direct taxes \\
Income \\
Property \\
Other \\
Indirect taxes \\
Import \\
Export \\
Excise \\
Other \\
Judicial activities \\
Non-tax sources \\
Transfer payments \\
Other
\end{tabular}

Current Pesos Constant Pesos $(\$ 000)$

$$
\begin{gathered}
90,762 \\
84,355 \\
18,803 \\
15,418 \\
3,655 \\
- \\
61,703 \\
23,754 \\
12,424 \\
22,551 \\
2,974 \\
3,849 \\
6,358 \\
1,102 \\
5,256
\end{gathered}
$$

132,352

121,960

28,948

20,836

8,086

81,107

28,349

19,000

29,513

4,246

11,905

3,256

7,136
(\$000) (1962)

84,371
78,415
17,479
14,081
3,398
-
57,358
22,081
11,549
20,963
2,765
3,578
5,910
1,024
4,884

122,652

113,022

26,827

19,309

7,493

24
75,163

26,271

17,608

27,350

3,935

11,033

9,630

3,017

6,613

\begin{tabular}{rrr}
\multicolumn{2}{c}{$\begin{array}{c}\text { Per Capita (\$) } \\
\text { Current }\end{array}$} & Constant \\
& & $\begin{array}{r}\text { Percent } \\
\text { Current }\end{array}$ \\
24.67 & 22.93 & 100.0 \\
22.93 & 21.31 & 92.9 \\
5.11 & 4.75 & 20.7 \\
& & 16.7 \\
& & 4.0 \\
16.77 & 15.59 & 68.0 \\
& & 26.2 \\
& & 13.7 \\
& & 24.8 \\
1.05 & 0.98 & 3.2 \\
& & 4.2 \\
& & 7.0
\end{tabular}

$\begin{array}{rr}37.29 & 34.56 \\ 34.36 & 31.84 \\ 8.16 & 7.56\end{array}$

100.0

92.1

21.9
15.7

6.1

0.1
61.3

21.4

14.4

22.3

$3.35 \quad 3.11$
Percent Percent

of Taxes of GDP

$\begin{array}{rr}100.0 & 10.3 \\ 22.3 & 9.6 \\ 18.0 & 2.1 \\ 4.3 & 1.7 \\ - & 0.4 \\ 73.1 & - \\ 28.2 & 7.0 \\ 14.7 & 2.7 \\ 26.7 & 1.4 \\ 3.5 & 2.6 \\ 4.6 & 0.3 \\ & 0.4 \\ & 0.7\end{array}$

0.7

11.6

10.7

2.5

1.8
0.7

$<0.1$
7.1

2.5

1.7

2.6

0.4

1. 0 
charges are included within each of the broad categories tabulated.

Income taxes include levies on personal and corporate incomes as well as on inheritances. In Costa Rica, only income derived from Costa Rican sources is taxed. Companies and individuals are taxed at the same rate. There is no capital gains tax and dividends from companies that have paid Costa Rican income tax are not taxed. El Salvador is the only country in Central American to have separate tax rates for juridical and individual taxpayers, and to tax undistributed profits.

Moreover, El Salvador extends the income tax concept downward to enable lower-income persons, who would otherwise fall outside the realm of income taxes, to participate. This is accomplished through the medium of the vialidad, a four-part tax on almost everything. Part $A$ is a tax on 'liquid capital' and is actually included under property taxes. Liquid capital includes, but is not limited to, real estate, livestock, mortgages, accounts receivable, loans outstanding, cash, savings, bank deposits and business investments including professional offices and automobiles. Part B is a flat rate of $\$ 4.00$ per annum assessed on all persons following the 1 iberal professions-lawyers, doctors, clergy and the like; army officers are specifically exempted. Part $\mathrm{C}$ is a special income tax on salaries and wages of any amount and Part D is levied on artisans and workers, with categories from large, well-capitalized enterprises to 'artisans without shops' and unskilled workers. The only exceptions to the vialidad are minors, persons over sixty, members of the armed forces, school teachers and married women--unless, of course, any of these own property. 
Property taxes include, in El Salvador, Part A of the vialidad and, in Costa Rica, real property and gift taxes. Unlike the rest of Central America, El Salvador levies no special tax on insufficiently 31

used land.

Indirect taxes include import duties, export taxes and levies on internal consumption. Imposts on imports and exports are both general and specific, both ad speciem and ad valorem. In addition to commercial duties, individuals often pay import and export taxes on personal shipments of goods with nominal or no cash value. For example, this writer was required to pay no less than seven taxes, each a pittance, as import duties on a package of newspaper clippings sent him in Costa Rica from the United States.

In Costa Rica, over one-half of all export taxes come from a special levy on each hundredweight of sugar exported; similar taxes are imposed in El Salvador on coffee and shrimp. The coffee tax accounts for more than 80 percent of the total export tax.

Excise taxes are the largest single segment of current income for both national governments. The structure is much the same in the two countries. Generally, the taxed comnodities are liquor, gasoline, soft drinks, tobacco and matches. The details of the excise tax are complex and confusing. Costa Rica lists, in summary, over 160 different ones, including 11 distinct taxes on 1 iquor alone.

A third class of tax revenue found in both countries but unknown in the United States is entitled Juridical Acts. In Costa Rica this includes a tax on public spectacles and in El Salvador proceeds from traffic fines and the activities of the finance police. In both coun- 
tries, however, the bulk of the money generated in this category comes from the sale of stamps and stamped paper. Most legal/official paperwork is required to be drawn up on paper prestamped or imprinted with a certain value. The cost of the paper generally increases with the amount of the transaction. Among the documents which by law must be executed on stamped paper are wills, contracts, petitions to courts, depositions and applications to various administrative offices. Such paper is generally purchased at retail; the retailer having already paid the tax, and used as needed. Stamps are usually purchased and cancelled in one transaction, and affixed to stamped paper. Fees for particular activities are often listed as a paper of some amount and a stamp of some amount.

Again, a personal example may prove instructive. The writer wished photocopies of materials of which a government agency had only one copy. Administrative regulations forbade the use of the agency's copying machine for any but specified agency business, even if paid for on the spot. It was decided, however, that the agency head would entertain a properly executed petition for temporary removal of the documents for copying outside the office at a commercial copy center. The petition was to be presented on a two colon paper with a stamp of five colones. The paper was purchased from a stationer, the petition typed thereon, signed and dated. (Had the petition been longer than one page, or had a mistake been made that required starting anew, additional sheets of stamped paper would have to have been purchased and used.) The petition was then presented to the agency's fiscal officer who sold, affixed and cancelled the five colon stamp. The petition 
was then presented to the agency head who approved it and the writer, with passport held as bond and accompanied by a functionary of the agency, was permitted to carry off the documents and have them commercially photocopied.

Non-tax revenues are derived from a variety of sources. Among the more lucrative are: patents, copyrights and trademarks; fees for various consular activities; and charges for various licenses, permits and government services. It should be noted that the figures in this section apply only to general government revenues. Hence user charges for utilities such as electricity and telephone service provided by autonomous or semi-autonomous government agencies are not included.

One final aspect to be considered before the actual comparison of the revenue structures is the collection procedure. Income taxes are easy. As in most jurisdictions they are withheld at the source for salaries and wages and quarterly payments are required from corporations and the self-employed. Property taxes are handled differently in the two countries. In El Salvador, bills are mailed out, with the taxes to be paid to the Direct Tax office. Little difficulty is encountered in collecting these because these must be paid in order to receive a current boleto de vialidad. This tax receipt is required, along with the cedula, before any formal or official activities such as applying for a passport or renewing a driver's license, may be undertaken.

In Costa Rica the practice differs considerably. As one property owner described it:

There is no notice of tax. They change the rates maybe every five years. If you get a letter it means you are in 
trouble. Fines are levied but there is apparently no means of collection. You go down automatically two or three times a year and pay. Control and bookkeeping are bad. They may charge you for someone else's property. Pay in the bank. There's no automatic yearly increase in tax--only if you do something to the house does the value go up. 33

It should be noted that almost all financial transactions with the Costa Rican government are carried on through the banks; it makes no difference which one, since all are government-owned.

Indirect taxes are usually collected at the source, e.g., the liquor or match factory in the case of excise taxes. In E1 Salvador, sufficient excise stamps to cover the expected size of a given shipment are purchased from the Indirect Tax office and affixed before the shipment leaves the source. In Costa Rica, again, the seals are purchased from a bank. Import and export charges are levied by the Customs office, and collected on the spot. This is one of the rare cases in Costa Rica where payments are not made through a national bank.

Scofflaws and tax evaders are to be found in the two Central American republics as well as elsewhere. Once more, two very different mechanisms have been established to deal with non-payment. El Salvador has set up a special branch of the Tax Office known as the Finance Police. This force is to root out and prosecute malefactors and compel them to pay their share to the public purse. The efforts of the Finance Police are directed especially at two kinds of tax avoiders: smugglers, and even more so, at those who collect taxes from their customers (e.g., gasoline wholesalers) and fail to remit the funds to the government.

Costa Rica has chosen to rely more on the free enterprise system and less on the coercive powers of the state. A system has been cre- 
ated of fiscales especificos. These are special attorneys who are assigned debts owed to the central government, both taxes and other arrears. Fiscales especificos may collect these debts any way they see fit, by judicial or extrajudicial means. They receive a percentage of all monies so collected.

With this background on the general revenue structure, it remains to compare the two countries and see how each has altered over the five-year period. Returning to Table XI we can examine the changes in Costa Rica. Using the constant 1962 peso figures we note that current income and tax revenues increased, both by about onefifth. We note further, however, that direct taxes decreased by over 25 percent but that this decrease was more than offset by a 50 percent increase in indirect taxes. One of the more intriguing figures was the drop in per capita taxes; a very small drop, only one percent, but a decrease nonetheless. Another unexpected decrease was in the portion of the GDP taken up by taxes; in this case the drop was a substantial 13 percent. This decrease is particularly remarkable given Costa Rica's tradition of a constantly expanding government role in the society and economy.

Within the tax structure itself a number of major shifts may be detected. The most obvious and most significant of these is the move from an indirect-direct tax ration of $1.5: 1$ to $3: 1$. In other words, indirect taxes were relatively twice as important in 1972 as in 1967. Probing deeper into the internal makeup of each tax category, the composition of the shift may be determined. Income taxes declined severely in importance; property taxes almost disappeared. On the in- 
direct tax side miscellaneous taxes, unknown in 1967, made up more than four percent of the total tax revenue in 1972, just about compensating for the decline in importance of import duties. The major increase took place in excise taxes which soared from less than 30 percent of the total to more than 45 percent, consolidating their position as the single most lucrative tax source.

Specific causes behind some of these shifts are worthy of mention. The miscellaneous indirect tax category is made up almost exclusively of a 7.5 percent ad valorem tax on coffee beans delivered to beneficios. The property tax was for the most part turned over to the municipalities. During this period Costa Rica underwent considerable inflation. Most prices increased faster than most wages and salaries. Excise taxes on the rapidly escalating prices of goods provided the government with a fiscal surplus. The built-in flexibility of these taxes thus increased their total share under the inflationary circumstances. It would seem that demand for most of the commodities against which excise taxes are levied is quite inelastic with respect to price. Table XII shows the changes in central government revenue in E1 Salvador over the period 1967-1972. Immediately evident is the increase, in constant pesos, of both current income and taxes over the period, both by more than 40 percent. Direct taxes rose by over 50 percent and indirect taxes by 30 percent. Per capita tax burden also increased, by almost 50 percent. A decrease, however, was noted in the portion of the GDP devoted to taxes; it went down by 12 percent.

Some shifts also occurred in the composition of the tax struc- 
ture, although not as marked as in Costa Rica. Direct taxes became relatively more important, although not by much. Import duties' share declined. The largest change was in the category of juridical acts which more than doubled its proportional contribution. In summary, then, the Salvadorean tax structure in 1972 appeared very much as it had in 1967.

Comparing the tax structures of Costa Rica and E1 Salvador as both existed in 1972, some significant factors are evident. One of the most obvious shows that per capita taxes in Costa Rica are twice those in El Salvador. In both countries, excise taxes are the largest single source of income, but they are almost twice as important in Costa Rica as in El Salvador. Proportionally, El Salvador is eight times as dependent on export taxes as is Costa Rica. Assuming the tax is added to the price of outbound commodities, primarily coffee, E1 Salvador is thus able to effectively export 15 percent of its total tax burden. In the realm of direct taxes, Costa Rica derives a greater proportion of its revenue from income taxes but the difference is almost exactly countered by El Salvador's greater use of the property tax. Finally, juridical activities provide only about one percent of Costa Rican tax revenue while accounting for almost ten percent in El Salvador.

We can conclude our comparison of tax structures with some qualitative assessment of the differences found. Costa Rica uses its fiscal policy almost exclusively for money-raising purposes; El Salvador also uses its for economic growth purposes. Speaking of a series of recent revisions to the Salvadorean tax system, Virginia Watkin gives 
as their major rationale:

To change the tariff system from one which was primarily fiscal or money making in object to one which would encourage the investment of capital in productive activity, promote the rational use of labor, and encourage the efficient investment of monetary reserves as well as provide the government with revenue. 35

A variety of sociopolitical factors underlie this difference in approach to fiscal policy. First, Costa Rica needs the money more. It has undertaken a wide range of expensive social programs which require continuous funding. El Salvador has committed far less resources to this activity, and has not raised the expectation level of its citizenry nearly as high.

Second, Costa Rica by virtue of its more open, accessible political system needs be more responsive, with cash as well as symbols, to the demands of its people for more, and more expensive, services. Salvadorean decisionmakers are somewhat more isolated, and insulated, from mass political pressures. They are thus freer to engage in economically rational long-term planning and investment strategies. Moreover, they are encouraged in this by the economic elite, the main source of political pressure on the policymakers.

Third, as noted above in the section on national economies, Costa Rica has a more productive and advanced economy than does E1 Salvador. The former country, then, is not under the same compulsion as the 1atter to address their fiscal policy toward economic development.

One additional comment here might be addressed to those accustomed to thinking of national government revenue structures in the context of more developed nations. North Americans tend to associate national taxes with income taxes, personal and corporate. To their eyes, 
the tax structures of Costa Rica and El Salvador with their heavy dependence on indirect taxes may seem a bit bizarre. It must be remembered however, that to have the income tax as national fiscal backbone requires a considerable income-taxable population. The most readily income-taxable group, the middle-class wage and salary earner, is far too small in the Central American countries to carry this burden. The indirect taxes, although tending to be regressive, do spread the burden more evenly throughout the population.

\section{National Government Expenditure Patterns}

The final economic factors to be considered here are the expenditure patterns of the two national governments. Data on these patterns may be found in Table XIII for Costa Rica and in Table XIV for EI Salvador. Analyses will first be carried out on changes within each of the countries from 1967 to 1972 , followed by a comparison of the two countries for the latter year.

Immediately evident in examining the changes over time in the Costa Rica pattern is the substantial increase in total expenditure. Overall expenditures, in constant pesos, increased by about 150 percent. Some of this increase can be accounted for by the cost of serving an expanded population but per capita expenditures also more than doubled. The greatest change was in the area of Public Health and Social Assistance, but the Economic and Education categories also showed massive increases.

In terms of distribution, Education continued to be the most expensive activity with Economic expenditures in second place. These two, and Public Health, each added about eight percent of the total to 
TABLE XIII

COSTA RICA NATIONAL GOVERNMENT EXPENDITURES, 1967 AND 1972

Expenditures - 1967

Current Pesos

Constant Pesos

Per Capita $(\$)$

Percent of Percent

$(\$ 000)$

(\$000) (1962)

Current Constant

Expenditures

of GDP

\section{Sector}

Economic

Public Health/

$\begin{array}{rrrrrr}19,878 & 19,118 & 13.12 & 12.63 & 17.6 & 2.9 \\ 25,682 & 24,701 & 16.96 & 16.31 & 22.8 & 3.7 \\ 2,217 & & & & & \\ 618 & 2,132 & 1.46 & 1.41 & 2.0 & 0.3 \\ & 594 & 0.41 & 0.39 & 0.1 & <0.1\end{array}$

Social Assistance

Other Social

Defense

Justice

Other

$-$

$-$

$-$

$-$

Included in category 'Other'

Total

64,450

61,989

$42.56 \quad 40.94$

57.1

9.3

112,845

108.536

74.53

71.68

100.0

16.3

Expenditures - 1972

Economic
Education
Public Health/
$\quad$ Social Assistance
Other Social
Defense
Justice
Other

\begin{tabular}{rrrrrr}
53,931 & 43,017 & 47.24 & 37.68 & 25.3 & 4.6 \\
64,017 & 51,062 & 56.06 & 44.72 & 30.0 & 5.5 \\
22,415 & & & & & \\
6,949 & 17,879 & 19.63 & 15.66 & 10.5 & 1.9 \\
- & 5,540 & 6.09 & 4.86 & 3.3 & 0.6 \\
13,245 & - & - & - & - & - \\
53,014 & 10,565 & 11.60 & 9.25 & 6.2 & 1.1 \\
\hline 213,570 & 42,286 & 46.43 & 37.03 & 24.8 & 4.5 \\
\hline
\end{tabular}

170,352

$187.06 \quad 149.21$

100.0 
TABLE XIV

EL SALVADOR NATIONAL GOVERNMENT EXPENDITURES, 1967 AND 1972

$$
\text { Expenditures - } 1967
$$

\begin{tabular}{|c|c|c|c|c|c|c|}
\hline & $\begin{array}{l}\text { Current Pesos } \\
(\$ 000)\end{array}$ & $\begin{array}{l}\text { Constant Pesos } \\
(\$ 000)(1962)\end{array}$ & $\begin{array}{l}\text { Per Cap } \\
\text { Current }\end{array}$ & $\begin{array}{l}\operatorname{ta}(\$) \\
\text { Constant }\end{array}$ & $\begin{array}{l}\text { Percent of } \\
\text { Expenditures }\end{array}$ & $\begin{array}{l}\text { Percent } \\
\text { of GDP }\end{array}$ \\
\hline \multicolumn{7}{|l|}{ Sector } \\
\hline Economic & 25,340 & 25,089 & 8.20 & 8.12 & 28.0 & 2.9 \\
\hline Education & 22,364 & 22,143 & 7.24 & 7.17 & 24.7 & 2.5 \\
\hline \multicolumn{7}{|l|}{ Public Health/ } \\
\hline Social Assistance & 11,593 & 11,478 & 3.75 & 3.71 & 12.8 & 1.3 \\
\hline Other Social & 1,039 & 1,029 & 0.34 & 0.34 & 1.1 & 0.1 \\
\hline Defense & \multicolumn{6}{|c|}{ Included in category 'Other" } \\
\hline Justice & \multicolumn{6}{|c|}{ Included in category 'Other' } \\
\hline Other & 30,237 & 29,938 & 9.79 & 9.69 & 33.4 & 3.4 \\
\hline Total & 90,573 & 89,677 & 29.31 & 29.02 & 100.0 & 10.3 \\
\hline \multicolumn{7}{|c|}{ Expenditures - 1972} \\
\hline Economic & 35,218 & 32,637 & 9.60 & 8.90 & 22.9 & 3.1 \\
\hline Education & 42,218 & 39,631 & 11.65 & 10.80 & 27.9 & 3.7 \\
\hline \multicolumn{7}{|l|}{ Public Health/ } \\
\hline Social Assistance & 16,475 & 15,268 & 4.49 & 4.16 & 10.7 & 1.4 \\
\hline Other Social & 9,584 & 8,882 & 2.61 & 2.42 & 6.2 & 0.8 \\
\hline Defense & 9,658 & 8,950 & 2.63 & 2.44 & 6.3 & 0.8 \\
\hline Justice & 10,085 & 9,346 & 2.75 & 2.55 & 6.6 & 0.9 \\
\hline Other & 29,698 & 27,522 & 8.09 & 7.50 & 19.4 & 2.6 \\
\hline Tota1 & 153,484 & 142,236 & 41.82 & 38.76 & 100.0 & 13.4 \\
\hline
\end{tabular}

SOURCES: UNICEF, Las Sociedades Actuales, for 1967 figures; CONAPLAN, Indicadores, for 1972 figures. 
their outlays at the expense of, primarily, general administration. Overall, the portion of the GDP devoted to general expenditures of the national government increased from 16.3 percent to 18.3 percent during the five-year period.

E1 Salvador also showed an increase from 1967 to 1972, but of less than 60 percent when measured in constant pesos. Per capita expenditures increased by about one-third. Although other sectors showed a greater proportional increase, Education outlays went up the most absolutely.

A number of changes in the distribution of expenditures occurred over the five-year period. In probably the most significant of these, Education moved past Economics to become the most expensive sector of Salvadorean government activity. In another important change other Social activities increased their share of expenditures more than fivefold. The portion of outlay spent on Public Health and Social Assistance declined slightly. Overall expenditure consumed 13.4 percent of the GDP in 1972, an increase of 3.1 percent over the 1967 figures.

Two points of comparison between Costa Rican and Salvadorean central government expenditure patterns stand out at once. One is the much larger absolute and per capita outlay by Costa Rica; the other is the general similarity in distribution. On a per capita basis, Costa Rica spends almost four times as much as El Salvador; in the Education and Economic sectors more than four times. Costa Rica spends a slightly higher percentage on Education and Economic; the difference just about accounts for the portion El Salvador spends on Defense. Justice and Public Health account for about the same proportion of the outlay in 
both cases. Finally, it may be noted that E1 Salvador is increasing the share of its GDP spent on public activities faster than is Costa Rica. At the present rate of change, however, it would take another 23 years before the two countries spent equal shares of their GDPs in the public sector.

\section{SOCIAL BACKGROUND FACTORS}

Again, policymaking theory holds that a variety of demographic and other social factors may affect both the policy process and the outputs therefrom. Among the factors postulated as playing this role are: population, its age and sex structure and rate of increase; internal migration patterns; levels of educational achievement; and group structure.

\section{Population And Trends}

The populations of El Salvador and Costa Rica, and the urban areas of their capital cities, as of the most recent census, are presented in Table XV. Population changes for the decade preceding these headcounts are also presented.

Several significant comparisons and contrasts suggest themselves. Although Costa Rica had a very high annual population growth, that of El Salvador was even higher. In Costa Rica, the urban population grew more than two and a half times as quickly as the rural population; in El Salvador urban growth was only slightly faster than rural growth. In both cases the countries remain about three-fifths rural and twofifths urban in terms of population. 
TABLE XV

POPULATION AND DECENNIAL CHANGES

Costa Rica

1963

1973

Change

1963-1973

Average Annual

Percent Change

1961

1971

Change

1961-1971

Average Annual

Percent Change

Population
Population
Change
Average Annual
Percent Change
Per-

\begin{tabular}{|c|c|c|c|c|}
\hline $\begin{array}{l}\text { Rural } \\
\text { Population }\end{array}$ & $\begin{array}{l}\text { Per- } \\
\text { Cent } \\
\end{array}$ & $\begin{array}{l}\text { Urban } \\
\text { Population }\end{array}$ & $\begin{array}{l}\text { Per- } \\
\text { Cent } \\
\end{array}$ & $\begin{array}{l}\text { Total } \\
\text { Population }\end{array}$ \\
\hline$, 085,973$ & 59.0 & 754,758 & $\begin{array}{l}34.5 \\
41.0\end{array}$ & $\begin{array}{l}1,500,214 \\
1,840,731\end{array}$ \\
\hline
\end{tabular}

210,242

$-6.5$

294,215

$+6.5$

504,457

2.4

6.4

3.8

E1 Salvador

$\begin{array}{rrrrr}1,544,100 & 61.5 & 966,900 & 38.5 & 2,511,000 \\ 2,149,100 & 60.5 & 1,405,600 & 39.5 & 3,554,700 \\ 605,000 & -1.0 & 438,700 & +1.0 & 1,043,700\end{array}$

$\begin{array}{lll}3.9 & 4.5 & 4.2\end{array}$

$\underline{\text { San José }}$

1963

327,279

318,970

San Salvador

1973

91,691

351,726

1961

1971

560,504

208,778

2.8

5.9

SOURCES: El Salvador Census of 1971; Costa Rica Census of 1973

Unexpectedly, San José grew not only more slowly than Costa Rican urban centers generally but also more slowly than the country as a whole. This is not in keeping with traditional wisdom as to growth rates of primate cities. San Salvador, on the other hand, increased its population at a greater rate than both El Salvador and other Salvadorean urban centers. Some possible reasons for this differential will be suggested below. 
Although accurate intercensal population estimates are difficult to obtain, indications are that in the most recent years the rate of population growth slowed in both countries. El Salvador dropped to 3.9 percent in 1974 ; this was still the highest rate of natural in36 crease of any nation in the world. Costa Rica's rate of population growth is believed to have dropped below two percent annually. Among the evidence offered to support this belief is the closure of some schools for lack of pupils.

A peculiar difficulty arises with the 1971 census in El Salvador. At that time hostilities and tensions associated with the socalled 'Soccer War' were still at their peak. A large but indeterminate number of Salvadorean nationals, usually squatters and/or residents of Honduras, were temporarily driven back into El Salvador. It is not known how many of these were or ought to be counted in the census, nor where within El Salvador they were located. CONAPLAN assumes most of them did not appear in the census figures.

\section{Age and Sex Structure}

The structure of the population by age and sex for both countries and urban areas is shown in Table XVI. Once again some worthwhile comparisons, both internally between city and country, and crossnationally, may be made. In both Costa Rica and El Salvador the country as a whole shows a higher proportion of persons under age fourteen than does the capital city. On the other hand, both cities show a higher proportion of those between fifteeen and fifty years of age.

Two aspects of the age distribution in Costa Rica deserve mention: one, the number of children in the youngest age bracket is less 

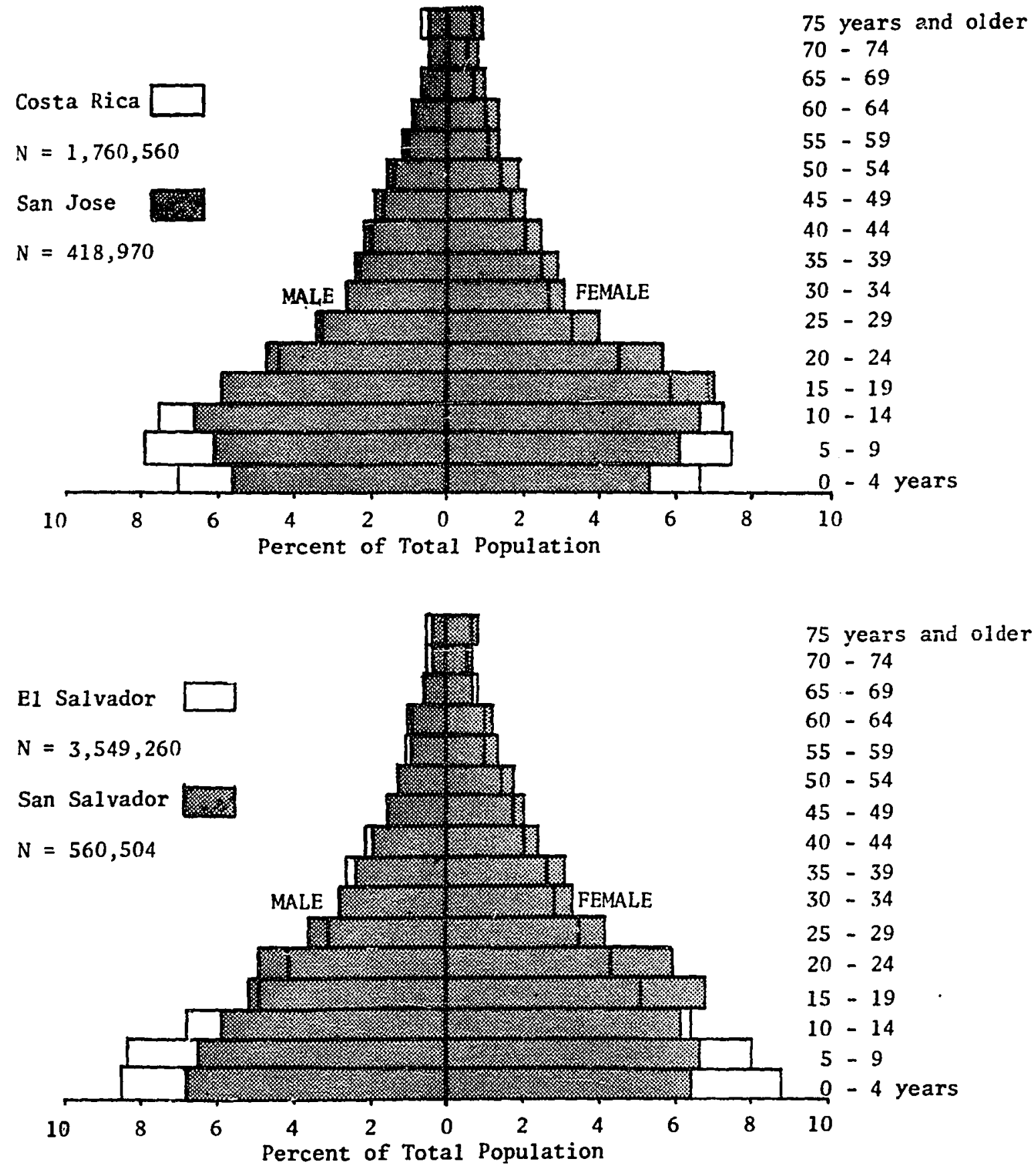

Sources: Costa Rica Census of 1973 San Salvador Census of 1971 
throughout the country than the number in the five-to-nine category. In San José each of the two lowest age categories has fewer members than the one immediately above it. This supports our contention of a decreasing rate of population growth in Costa Rica, a decrease that is more marked in San José than in the remainder of the country.

In each case the Index of Femininity (IF) is higher for the city than for the nation at every age over ten and exceeds 100 in every case over age 15 . This holds even though Costa Rica as a whole has a population that is over 50 percent male. Indices of Femininity may be found in Table XVII.

TABLE XVII

INDICES OF FEMININITY (IF)

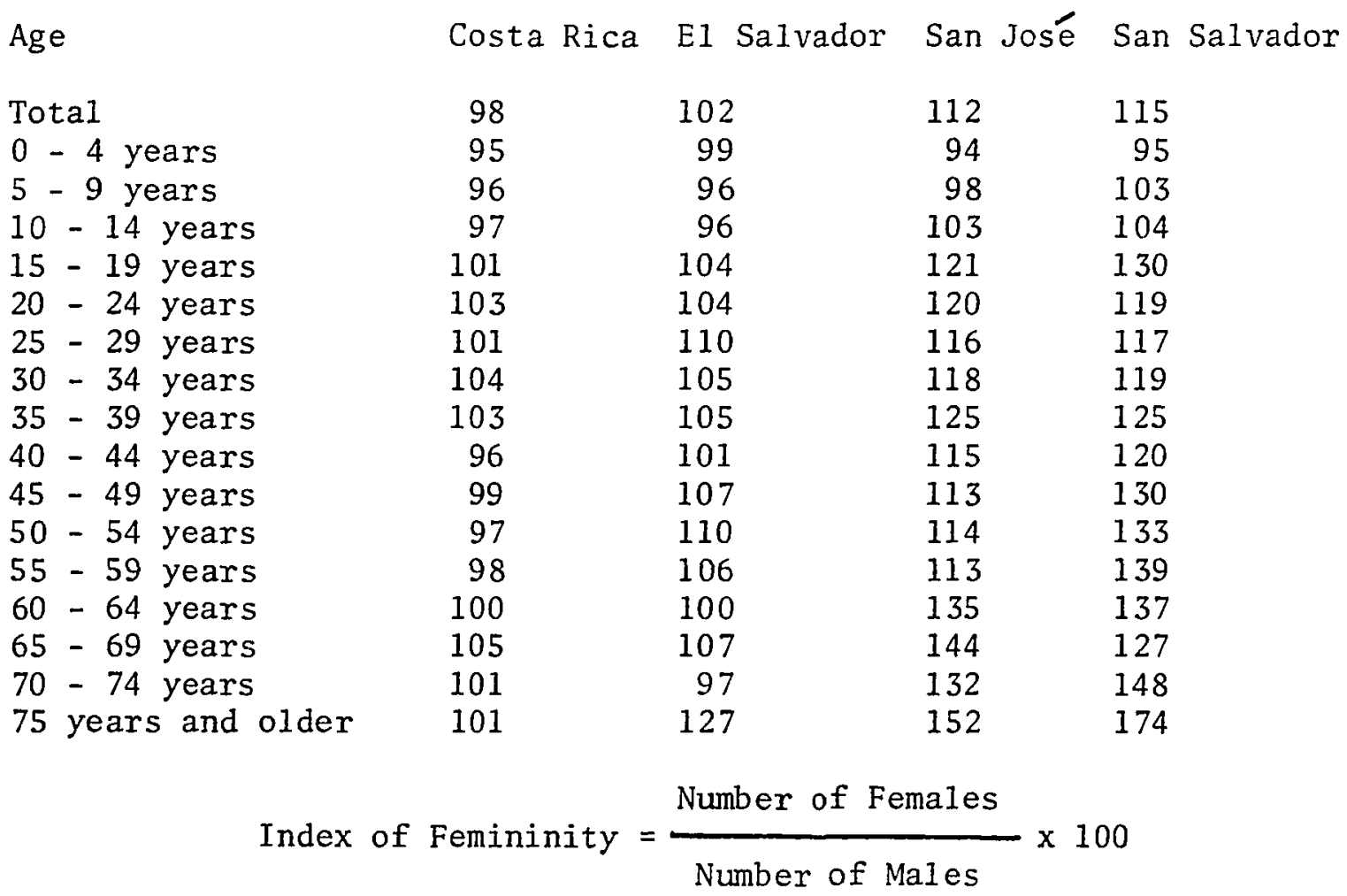

SOURCES: El Salvador Census of 1971; Costa Rica Census of 1973. 
In absolute numbers, the greatest excesses of females over males in San José and San Salvador is found in the 14 to 44 age bracket. IFs reach their maxima in the oldest age brackets, pointing up simply that here as elsewhere, women live longer than men.

Two possibilities are suggested by the data above: one, that there is a movement into the capital cities from the rest of the country by young adults; and two, that the majority of the young adults so migrating are women. It will be shown below the extent to which other data and observations support these migratory hypotheses.

\section{Internal Migration}

Scholarly literature on migration from countryside to city in Latin America (and in the developing nations in general) abounds. Theories and explanations are offered, causes and effects are suggested, analyses proliferate. Nonetheless, reliable data on this phe-

nomenon are rare. A few general tenets may be mentioned. Inmigration to cities, especially to capital cities, and even more especially to primate cities such as San José and San Salvador is larger than outmigration. Primate cities, therefore, are expected to grow much more quickly than rural areas. Factors leading to migration include both attraction factors to the cities and repulsion factors from the countryside. Marcia Koth and associates, for example, have identified 39

fifteen of these. Other basic tenets hold that migrants are overwhelmingly poor and male.

In this study we will be concerned only with those aspects of migration that impinge directly on our central theme or that suggest some alternatives to traditional wisdom. To reiterate an earlier 
statement, reliable data on internal migration are indeed scarce. It is theoretically possible to get a quantitative picture of migration from either a macro or a micro viewpoint. In a macro approach, one would need data on initial population, birth rate, death rate and final population for a jurisdiction for a particular time period. Put algebraically, $M=P_{t}-P_{o}(1+N R R)$ where $M=$ migrating population, $P_{t}$ $=$ population at end of time period $t, \bar{P}_{0}=$ population at beginning of time period $t$ and $N R R=$ net reproduction rate (birth rates - death rates over time period $t) . P_{0}(N R R)$ then, would give the population at the end of time period $t$ if only natural increase had occurred. The difference between this figure and the actual head count at the end of the period would give the size and direction of the migration.

No recent studies have adopted this approach. Again, at least part of the reason for this must be the uncertainty attached to population statistics, particularly in Costa Rica. Two earlier studies however did adopt this approach. The highlights of their findings are presented below, with the ususal caveat.

In a 1970 study Jeffry Gibson looked at urbanization in Costa 40

Rica and El Salvador, as well as Honduras. The results are shown in Table XVIII. Two points need be mentioned here. The figures are for migration to provinces, not to urban areas. It may be assumed that the bulk of the migrants settled in the urban areas but this is not specified. In addition, migration numbers and annual percent increases do not seem to jibe.

In a slightly earlier study for the United Nations (also using figures to 1963) J. van den Boomen examined the San Salvador Metropoli- 
41

tan Area. He not only calculated the size of migration but determined a number of characteristics of the migrants such as place of origin and age at time of migration. He found some 125,000 migrants in metropolitan San Salvador, about 42 percent of the population. Further, he determined that over 80 percent were under 30 years of age when they moved and that three-quarters had migrated from towns of more than 10,000 population.

TABLE XVIII

NET INMIGRATION

Period

$1930-1950$

$1950-1963$

$1930-1950$

$1950-1963$
San José

20,700

25,200
San Salvador

68,600

48,700

Annual growth rate due to migration

(Note: Actual first-time period for San José is 1927-1950.)

SOURCE: Jeffry Gibson, Demographic Analysis of Urbanization.

The micro approach to calculating migration involves sampling from a selected population and extrapolating the results. This ap42

proach was followed by White in his 1969 study. He interviewed 270 migrants randomly selected from seven areas of San Salvador chosen to represent different types types and qualities of housing but excluding upper-middle class and above. Some of his more noteworthy conclusions were: that only one-quarter of the people entering San Salvador came from the countryside; that the majority of the migrants were young women, hence more than a quarter of the metropolitan population 
is women of childbearing age while less than one-fifth of the rural population is; and that half the women and 40 percent of the men who migrate to the capital do so for economic reasons. One interesting finding was that 12 percent of the women move to the capital to join a man while another 13 percent do so to get away from one--husband, father or step-father.

White's findings, therefore, are consistent with our supposition from the age-sex distribution data that migration to San Salvador is occurring, and that the migrants tend to be young women. Our findings do not support the conventional view of the migrant population as predominantly male.

The greatest discrepancy between the implications of our data and traditional wisdom lies in San José. San José is indisputedly a primate city yet during the 1963-1973 decade it grew more slowly than not only other Costa Rican urban centers but also than the country as a whole. Part of this, it is reasonable to assume, is the result of a lower natural reproduction rate in the city, as suggested by the population pyramid (Table XVI). The case can be made, logically, that women in the capital are better educated, have greater access to medical advice and birth control methods and consequently choose to have fewer children. We have, however, no data to support this contention (nor to refute it).

With land distributed slightly more equitably in Costa Rica, and the much lower rural population density than in El Salvador, the push from the countryside to the city is less in the former country. This could account for some decreased migration and hence for San José 's 
slower growth. In addition, it will be shown below that government decentralization policies, especially those of INVU are specifically designed to discourage growth in the metropolitan areas. Moreover, U.S.-type suburbanization is luring members of San Jose's growing middle class to residences outside the urban zone of San Jose Province. We can therefore offer explanations in the abstract for this phenomenon of slow urban growth but lacking reliable statistics we cannot prove our contentions.

In examining population movements within El Salvador another potential source of cityward migration was discovered. This particular concept has not heretofore appeared in the 1iterature. Without knowing how generally applicable it is in other countries it is presented here. Standard pictures of the rural life in developing areas show small farmers eking out a subsistence livelihood on their minifundia and working occasionally for a large landholder, either as rent for their small plots or to augment their marginal existence. Those who decide they cannot make it on the land move to town.

In San Salvador, however, a landless rural class has developed -the migrant farm laborer. An indeterminate number of (usually) men follow the crops, much as migrant farm laborers do in the U.S. They move from one end of the country to the other harvesting cotton, coffee and sugar cane. In the course of their travels they pass through various cities. Initially they may simply spend a day of two there between jobs. The stays become longer. Having visited a number of towns in this fashion, they may consciously choose one for longer stops or eventual settlement. On the one hand then, these farm 1abor- 
ers are 'accidental' migrants to the city in a way that no other group, save only perhaps military draftees, is. On the other hand, they rationally select their urban residence, not reacting simply to proximity or $\therefore$ the pull of the capital as the usual migrant is assumed to do.

Educational Achievement

Level of educational achievement is generally regarded as a social background factor influencing the quality of policymaking in both municipal and national situations. In this section we look very briefly at the educational accomplishments in the two countries. Both Costa Rica and El Salvador follow a system of education involving only slightly different nomenclature than in the U.S. Primary school encompasses the first six years, and is the only school most pupils ever know. Upon completing this, the student obtains a certificate allowing him to enter secondary school. The latter requires five years to complete and the graduate is awarded the title 'Bachelor of Sciences and Letters.'

From here the students may enter the University or attend spe44 cialized schools. Those who enter university with the intention of becoming, for example, physicians or lawyers, go directly into the professional schools; pre-law or pre-medicine courses of study as are found in the U.S. universities are unknown in Central America. Generally, a course of study in the university requires six years. Teaching faculty are usually part-time, earning the bulk of their income from outside practice of their professions.

Traditionally, Costa Rica and El Salvador have each had one $\mathrm{Na-}$ tional University, state-supported but otherwise autonomous. Both 
schools are currently housed in attractive suburban campuses. In 1966 a new university, José Simeon Cañas University of Central America, a Roman Catholic institution, was opened in the outskits of San Salvador. ${ }^{45}$ Table XIX indicates the relative educational achievements of the two countries.

TABLE XIX

EDUCATIONAL ACHIEVEMENTS

Costa Rica

E1 Salvador

Literacy Rate - Age 10 and over

1950

1960

1970
$79 \%$

$84 \%$

$89 \%$
$38 \%$

$49 \%$

$58 \%$

Percent of age group attending school - 1970

5-14 years

$15-19$ years

20-29 years
$67 \%$

$41 \%$

$5 \%$
$54 \%$

$24 \%$

$2 \%$

Percent of the population graduated from university - 1970

$2 \%$

$1 \%$

SOURCE: UNICEF, Las Sociedades Actuales.

Although precise figures do not exist, educational levels are higher in the capital cities. It is estimated that over 95 percent of those between ten and sixity years of age are literate in San José; the 1971 census found the Iiteracy rate for San Salvador to be 88 percent. Further, it is estimated that the percent of the population with a university education is three to five times higher for the capitals than for the countries as a whole. It can readily be seen that the Costa Rican population, by whatever measure is more advanced educationally than the Salvadorean. In recent years, 
however, El Salvador is closing the gap, especially in terms of basic 46

1 iteracy.

Group Structure

Although the 'average' citizen of El Salvador or Costa Rica might not associate himself with as many or as diverse organizations as his counterpart in the U.S., groups are not unimportant in these two countries. In a 1973 study, for example, John Booth found 66 percent of Costa Rican family heads to be members of one or more voluntary groups.

In this section we look briefly at three sorts of groups: business associations, unions and student organizations, and civic 48

groups. The nature of politics in Costa Rica and El Salvador would lead us to suspect that business associations might be more powerful and influential in the latter country than in the former. Empirical research supports this contention. In Costa Rica the chief spokesgroup for business interests is the Asociación Nacional de Fomento Económico (ANFE). It is small, with perhaps 300 individual and corporate members. It adopts an uncompromising laissez-faire liberal approach that is very much at odds with the social service orientation of the usually dominant PLN. The ideology and rhetoric of ANFE is carried to the people by La Nación, Costa Rica's most highly regarded but not politically influential daily newspaper.

In aligning itself automatically against the PLN on almost every issue, ANFE has not traditionally been able to influence policy to any major extent. (This could change now that a more business-oriented government with control of both Presidency and Assembly took office 
in July, 1978.) In fact, business organizations in general have been weaker than might be expected. One reason for this is that almost all businesses and business organizations act politically only through ANFE. If ANFE is not effective, they seek no other approach. A second reason is that coffee growers, the strongest agricultural sector, present no united front. Despite the existence of the Junta de Defense de Café (JUDECA) and its potential power, coffee growers constantly attempt to undersell one another in the international market, vitiating JUDECA and virtually eliminating their political influence.

No such political mistakes are made by the business organizations of El Salvador. The largest and most important of these is the Asociación Nacional de Empresas Privadas (ANEP). ANEP has some 400 corporate and 11,000 total members including 11 organizations, chief among which are the Sociedad de Comerciantes e Industriales Salvadoreños, the Comité de Bancos, Seguros y Financieras and the Cámara de Comercio e Industria (CACI). ANEP and its constituent members benefit from the domination of the national political scene by PCN, their ideological fellow. Nonetheless, ANEP takes nothing for granted and, along with CACI maintains a professional staff to look out for its interests at both the national and municipal levels.

In the agricultural realm as well, organization is tighter than in Costa Rica. Unlike the internal feuding that characterizes JUDECA, cooperation and profit maximization predominate in the quasigovernmental Compañía Salvadoreña del Café (COSDEC) .

The most powerful and active unions, in both countries, are the teachers' associations. Costa Rica's Asociación Nacional de Educadores 
(ANDE) is probably the most politically influential group of any kind in the country. It has a membership of 13,000 and is basically a closed shop; all educators in any establishment receiving public funds are required to join. It lobbies very intensively for its own interests with considerable effect. (It will be interesting to see the impacts on ANDE's political power of the decreasing need for teachers resulting from the reduced numbers of young children.)

The Asociación Nacional de Educadores Salvadoreños (ANDES) is even more active than ANDE. It may be, however, that ANDES is so militant as to cause some backlash against it. Moreover it is divided internally into factions of varying degrees of intransigence, and this dissension weakens its effectiveness in dealing with outside agencies, particularly with the national government.

Unions of other public employees are also found in both countries. In El Salvador these unions are legion; most small groups have their own organization, especially the more skilled tradesmen and those in critical occupations (e.g., garbage collectors). Despite the number of unions, the majority of public employees are not covered. The situation in Costa Rica is quite similar although the number of individual unions is smaller. The most important of these is the Asociacion $\mathrm{Na}-$ cional de Empleados Publicos (ANEP) but even ANEP represents only about five percent of the public employees, mainly lower status blue-collar workers.

Private-sector labor unions are found in Costa Rica but they are not so numerous, so well organized or so militant as those in El Salvador. No overall organization such as the AFL-CIO exists in E1 Sal- 
vador. Probably the closest is the Federación Unitaria Sindical de El Salvador (FUSS), an extremely militant group. Its tactics run more to general strikes attempting to seek government-mandated wage increases than to negotiations with or actions against individual employers or employer associations. One interesting feature of the Salvadorean labor scene is the presence of worker federations maintained basically as wings of the major political parties. The two most important of these are PCN's Confederación General de Sindicatos (CGS) and PDC's Unión Nacional de Obreros Cristianos (UNOC).

Both national universities have student organizations but they differ greatly. The Federacion de Estudiantes Costarricenses (FECR) is not generally politically active. Sporadically it rouses itself to protest against such matters of particular student interest such as increased bus fares and higher tuition but then lapses back into its wonted apathy. Its Salvadorean counterpart, the Asociación General de Estudiantes Universitarios Salvadoreños (AGEUS) is far more militant but no more effective. One recent government response to its demands was the complete closure of the National University from July through December, 1972.

Of most immediate interest to this study are the community organizations. In El Salvador these are of two kinds. One is the service club such as the Lions and the Rotary Women who occasionally venture into the realm of municipal politics. Because of their service orientation they are often successful in achieving aims of low political sensitivity (e.g., having garbage cans placed in downtown San Salvador). The other type of group is the community associations. They have no 
corporate status, no financial base and are effectively controlled by FOCCO. In general, the community groups tend to be ad hoc and transitory in nature and their sphere of interest limited to their immediate neighborhood.

In Costa Rica, however, some 300 development associations are found at the district, canton and provincial levels. As indicated above in the section on political structure, they are entitled by law to a certain share of municipal revenue. They also have status as public corporations. Like their Salvadorean counterparts, their interests are 1 imited to their immediate neighborhoods but they tend to be successful in such matters as obtaining improvements to community playgrounds. DINADECO trains leaders for these groups but does not control them, unlike FOCCO. Municipal officials often regard them as nuisances but are obliged to pay some attention to them although not in the setting of general municipal policy.

In summary, then, the following comparisons may be made between the various categories of groups in Costa Rica and El Salvador. In Costa Rica the business groups have aligned themselves in low-key opposition to the dominant PLN and generally play no important role in policymaking; in E1 Salvador the business groups are aligned with the dominant PCN and play a substantial role in policymaking, even to the extent of occupying two of the nine seats on CONAPLAN.

The Costa Rican government acts very much as patron to its citizens, including the working class. Most employees therefore feel very little necessity for active trade unionism and the movement, though not officially discouraged, is weak. The Salvadorean government does not 
play this role of patrón to the same extent; trade unionism is militant although not terribly successful in its attempts to gain wage and benefit increases through central government action. Teachers' unions are active in both countries. In Costa Rica they are united and lobby successfully for their interests; in El Salvador they are given to internecine warfare and are less successful in achieving favorable government action.

Associations of university students, traditional pressure groups in Latin America, operate with similar lack of success in both countries. Costa Rican university students are generally so low keyed and apolitical as to be ignored; the more radical, militant and activist Salvadorean students seem only to generate resentment against themselves.

Community groups are active, recognized, permanent, funded and often effective in Costa Rica. Their Salvadorean counterparts are less active, spatially constrained, transitory and usually without finances. The most successful ones are branches of international service clubs in their sporadic forays into the local political scences. Such community groups as exist in Salvadorean neighborhoods, particular lower-class and public-housing developments, are looked on by both PCN and PDC primarily as instruments to be manipulated for their own partisan political purposes.

THE GENERAL PLAN

It is a tenet of the planning creed that an overall plan for the development of an area will provide some framework within which ra- 
tional policymaking can take place. There exists a Plan for metropol50

itan development in San Salvador and none in San José. It might be expected therefore, that the policy processes in San Salvador and the outcomes thereof might be affected and improved.

A thorough examination of the General Plan, however, makes this appear unlikely. In the first place, the Plan is designed to react to expected population growth, not to influence it. Second, the Plan basically perpetuates current land use and transportation patterns; it does not suggest altering them. Third, it is couched for the most part in such vague terms as to make implementation both difficult in itself and even more difficult to measure or evaluate. Fourth, there is no reason to expect much attempt at implementation--plans for metropolitan San Salvador have been created for the past thirty years; all sit languishing in the office of the Director General of Urbanism and Architecture. Fifth, the Plan appears to have been drawn up in a vacuum; linkages to the outside are hardly mentioned. And finally, the greatest shortcoming from the point of view of this study, no role whatsoever for municipal government is even hinted at; the existence of twenty-two local governments in the area, including San Salvador, is ignored.

Given this situation, our initial assumption that the existence of the Plan would have an effect on municipal policymaking in San Salvador seems unlikely to hold. Nonetheless we look in subsequent chapters to see if we can find any difference between our two municipalities that can be traced to the Plan.

The above, then, is the examination of the various political, 
economic and social background factors we feel likely to influence the policy process and the outputs therefrom in San José and San Salvador, and to account for anticipated differences between the two municipalities.

In the following chapter we discuss the nature of the policy process as we actually find it, both in general and more specifically for the making of revenue policy at the local level in the municipalities. This process and its results are related and tied to the background factors in both Chapter VII and Chapter VIII. Chapter VII considers very specific connections between certain of the factors and day-to-day housing and municipal finance programs. Chapter VIII examines more holistically the relationships between the total package of background factors and the overall policy process and its consequences. 


\section{CHAPTER V NOTES}

1. Constitution of the Repub1ic of Costa Rica 1949 (as amended) (Washington, D.C.: Pan American Union, 1965).

2. Constitution of the Republic of E1 Salvador 1962 (Washington, D.C.: Pan American Union, 1966).

3. There is an exception to classification by size: the chief municipality of each district receives the title of city, regardless of its population. Thus, for example, Suchitoto with 5,300 persons is classified as a city while Cuscatancingo with a population of 18,800 is a pueblo.

4. See the discussion of Rojas, "E1 Codigo Municipal," above, p. 35.

5. Costa Rica, Municipal Code, Article 4.

6. Costa Rica, Municipal Code, Articles 4-10.

7. The party composition of the 1974-1978 San José Municipal Council was PLN - 5, PUN - 3, RD - 2, PNI - 1, PRN - 1, and PASO - 1 .

8. El Salvador, Municipal Act, Article 74 .

9. Municipality of the Central Canton of San José, Regulations Governing Internal Organization, Administration and Debate of the Municipal Council, Article 7.

10. The administrative structure of San Salvador was in a state of extreme flux during the period of the field work. The organogram and accompanying description constitute the best available snapshot of the structure at one point in time.

11. The Council's term actually begins and ends two months earlier. The most recently completed Council term, for example, ran from 1 May 1974 to 30 April 1978, while that of the Municipal Executive ran from 1 July 1974 to 30 June 1978 .

12. See page 117 above.

13. Chávez Mena, "Organización Municipal," p. 30.

14. Ebel, "The Decision-Making Process in San Salvador," p. 191.

15. Personal interview, 8 April 1974. 
16. For a complete account, see Alfred Cuzan, "Urban Resource Allocation and Policy Performance: Center-Local Linkages in El Salvador and Costa Rica," paper presented at the 1975 Annual Meeting of the American Society for Public Administration, Chicago, 1-4 April 1975 .

17. Not to be confused with the General Treasury of Specific Municipal Funds, an agency of the national government with which all municipalities are to deposit their funds.

18. El Salvador, Law of Municipal Finance Organization, Article 4.

19. Personal interview, 18 April 1974.

20. Costa Rica, Instituto de Fomento y Asesoria Municipal (IFAM), Filosofía, Objectivos y Programas de Trabajo, San José, 1971, p. 17.

21. This was the only Peace Corps Volunteer in either Costa Rica or E1 Salvador working on an urban project.

22. The President, two Vice-Presidents and the Cabinet constitute the Council of Government.

23. A number of smaller, usually agrarian-populist, parties contest elections in outlying areas but are not found in San Jose.

24. A straight proportional representation system, on a department basis, is used for elections to the Salvadorean National Assembly.

25. In both polities, as is traditional in Latin America, a great many physicians, surgeons and dentists are very active politically, even to the point of seeking fairly minor political office. These medical politicians may be found in all political parties. In North America this phenomenon is virtually unknown.

26. This is somewhat surprising as most Salvadoreans are technically illegitimate and there is no particular stigma attached to illegitimacy.

27. Literally. These charges and countercharges appeared in La Prensa Gráfica during the 1974 municipal election campaign in San Salvador.

28. The monetary unit used for comparative purposes here is the Central American peso which is equal in value to the U.S. dollar and will be indicated by \$C.A. Figures were initially in Salvadorean or Costa Rican colones and were converted into Central American pesos by the writer. Conversion values used were $\$ 1.00 \mathrm{C} . \mathrm{A} .=$ $\$ 2.50$ Salvadorean and $\$ 1.00$ C.A. $=\$ 6.62$ Costa Rican. The symbol $\phi$ is used for colones of both countries. 
29. UNICEF, SIECA, and ODECA, Informe Final: Conferencia Sobre La Familia, La Infancia y La Juventud de Centroamerica y Panamá (Guatemala: Editorial José de Pineda Ibarra, 1973), p. 116.

30. Barbara Stallings, Economic Dependency in Africa and Latin America, SAGE Comparative Politics Series, Vol. 3 (Beverly Hills: $\overline{\mathrm{SAGE}}$ Publications, 1972), p. 59.

31. Visual evidence of this can be seen in the existence of vacant lots in the heart of San Salvador. No such unused real estate may be seen in other Central American capitals.

32. Montero, "Evolución del Sistema Tributaria," Tables 8 and 11 (unpaged). This does not include a variety of municipal taxes on the liquor trade.

33. Personal interview, 25 March 1974.

34. It has, however, changed greatly from the 1940 s and $1950 \mathrm{~s}$ when import duties supplied 40 percent to 50 percent of total revenues. See Wallich, Public Finance, p. 52.

35. Virginia C. Watkin, Taxes and Tax Harmonization in Central America (Cambridge: Harvard University Law School, 1967), p. 233.

36. San José (Costa Rica) La Nación, 25 February 1974, p. 22A.

37. Estimates range from 63,000 to 300,000 . See White, El Salvador, p. 185 .

38. El Salvador, CONAPLAN, Indicadores: Económicos y Sociales 1973, San Salvador, p. 13.

39. Koth, Housing in Latin America, p. 19.

40. Jeffry Gibson, A Democratic Analysis of Urbanization: Evolution of a System of Cities in Honduras, El Salvador and Costa Rica, Latin American Studies Program Dissertation Series, no. 20 (Ithaca, New York: Cornell University, 1970).

41. United Nations, Economic and Social Council, Aspectos Demograficos y Socioeconómicos del Area Metropolitara de San Salvador, prepared by J. van den Boomen, (E/CN.12/CCE/ 333/TAO/LAT/54) January 1, 1966.

42. White, El Salvador.

43. Ibid., p. 159. This is the only one of the studies in which the methodology is specified.

44. In Costa Rica, Normal School and Schools for the Performing Arts. 
In El Salvador, Normal School and Schools of Nursing, Social Work, Agronomy, Physical Education and Engineering Technology. Students entering Trade Schools usually do so at the end of their primary schooling.

45. Two explanations are offered for the genesis of this university. One attributes it to the uneasinesss of the Church and some sectors of the economic elite over the 'Marxist bias' of the National University. Faculty members of the new university, however, perceive that their offerings of such disciplines as Industrial Engineering and Planning fill a vacuum left by the National University's concentration on Law, Philosophy, Art and Humanities.

46. A literate person is defined as one who can read, write and understand a simple paragraph. Those who can only write their names are classed as illiterate.

47. John Booth, "A Replication: Modes of Political Participation in Costa Rica," WPQ 29 (1976):628. A sample of 1,446 family heads was interviewed.

48. For a more thorough analysis of group participation, see Cuzan, "Central-Local Linkages"; and Ebe1, "Decision-Making Process in San Salvador."

49. The other members of CONAPLAN are the Ministers of Finance, Economy, Agriculture, Labor and Public Works; and the Presidents of the Central Reserve Bank and of the Republic.

50. El Salvador, Ministerio de Obras Publicas, San Salvador: Plan de Desarollo Municipa1, San Salvador, [1973]. 
CHAPTER VI

THE POLICY PROCESS

In Chapter III we presented a general view of the policy process and our model of choice for analysis thereof. Here we apply the analysis to our particular areas of interest, most particularly to municipal revenue policy. This chapter focuses on process, and more specifically on process within what we have defined as the boundaries of the political system. Policy output, that is, the current set of policy practices, will be described below in the subsequent chapter.

In the section on housing policy, emphasis is on the general nature of the process--what matters are to be considered, what questions are to be asked. Because of the national character of housing policy, no specific cases are examined in the area. Two cases are, however, examined in the revenue section. In San Salvador we look at a case of aborted overall tax reform and in San José at a successful case of a policy to introduce a new tax.

Case studies may be approached in one of two ways. From one viewpoint, the case is the heart of the analysis; all other material is only background against which to examine the particular case. From the other viewpoint, the case is merely illustrative of general principles presented elsewhere.

Which of these approaches is chosen is influenced to a large extent by available information. Where a number of different policies 
of the same type (e.g., revenue) can be located and traced from beginning to end, and where more general data are sparse and/or no welldefined framework for analysis exists, the former, inductive, approach is obviously appropriate. Where a reasonably well-developed theory exists, where data on the general situation have been assembled and where a framework for analysis is in place, the latter, deductive, approach fits. This is the approach selected here.

Particularly in the matter of revenue policy, we have on the one hand definite hypotheses and a framework for analysis and on the other hand a shortage of complete, informative cases. Our case studies, therefore, serve primarily as illustrations and as checks on our general assumptions.

\section{HOUSING POLICY}

Public housing policy in both Costa Rica and El Salvador is national, not municipal. National agencies have been set up in both cases to deal with housing. In El Salvador, municipalities are specifically excluded from housing planning. General provisions of 'good' public housing policy are indicated above in Chapter IV. The results of all this policymaking, the current package of rules and regulations and the actual provision of dwelling units, will be presented below in Chapter VII. Comparisons and contrasts will be indicated among INVU, IVU and FUNDASAL. Consequently, this chapter will consider housing policy only very briefly.

It is fair to state that with the establishment and funding of INVU and IVU respectively, both countries have completed the metapolicy- 
making stage. In the ongoing policy process in the realm of publicly supported housing, a variety of decisions need to be made on a more or less continuing basis.

The first issue the agency decides is the location of a public housing project. (For analytical purposes each publicly assisted housing project, whether for sale or rent, will be regarded as one policy package.) Location is the single most critical decision for a number of reasons, reasons that are not always the same in Costa Rica as in E1 Salvador.

Most public housing in El Salvador is in the capital metropolitan area; much of the government housing in Costa Rica is in outlying sections of the country. Even if we restrict analysis to the urban areas of San José and San Salvador, the locational considerations are different. In the San Salvador area, IVU must select its sites from those undeveloped areas not already dedicated to some non-housing use, and then work on acquiring them. INVU, on the other hand, owns a variety of sites (former coffee fincas) in the outskirts of San José. Its decision, then, is which ones, if any, to build on. Another very real constraint exists in San Salvador; ANDA simply does not have the capacity to provide acceptably priced water to elevations above 900 meters.

Following the decision as to location and influenced by the site and situational factors of the real estate chosen, policy as to type of construction is considered. Again, a number of subdecisions must be made before coherent policy can emerge. One question that needs be answered very early is, 'Do we build single-family units or multiple- 
family units or some combination of both?' It will be shown below that some external considerations, beyond the agency's judgments as to what best suits the needs of their clients, are involved at this stage of the decisionmaking process.

Two subsidiary questions regarding construction arise at this point--what sorts of construction material to use and how complete the housing ought to be. The former question is the more easily answered. Engineers and accountants can invoke a purely rational decisionmaking model and come up with a single best (most cost efficient) solution. Again, a difference between INVU and IVU is noted; INVU takes the state of the art as defined by the contractors/bidders as a given. It thus reduces its options, and its decisionmaking costs. IVU operates its own materials technology laboratories seeking better and cheaper materials; it must decide when and how much of its own technology to employ and test.

The other question, how far to go, is a hard political one and must be answered nearer the top of the agency hierarchy. Arguments can be, and are given for providing only cleared patches of earth and construction materials, for providing furnished turnkey housing, and for every intermediate position. The usual result of this argument will be indicated below.

The underlying purpose behind all these activities is, of course, providing housing for poeple. Not enough housing can be provided, however for everyone who is unable to purchase or rent in the private housing market. As a result, two pairs of decisions are necessary at this stage in the policy process. One deals with whether ruralites 
or urbanites are to be sheltered; the other with the appropriate income level population to be served.

Again, arguments can be made for concentrating on rural housing and equally valid counter arguments for an urban emphasis. Koth summarizes the five general arguments for rural housing:

1. Urban housing programs encourage cityward migration with its attendant problems.

2. Better housing in a rural area leads to more employment there and thus a tendency for people to remain.

3. Provision of housing in rural areas creates the potential for development of small family shop industries as bases for future industrial specialization.

4. Education of rurals through self help programs and the like integrates them into the national culture.

5. Provision of housing in rural areas can encourage colonization on un- or under-used land.1

Another argument made from time to time for concentration on rural housing provision is that the rural areas have the greatest need, i.e., that shortfall, both absolutely and proportionately, is greater in mural areas. Gustavo Antonini, for example, estimates a 1970 housing deficit for Costa Rica of 115,545 units of which 94,156 or 81.5 percent are needed in rural areas.

Proponents of an urban emphasis for public housing provision offer their own reasons in favor of this emphasis. The four most usual are:

1. Urbanization is inevitable, now is the time to make the transition smooth.

2. The rapid expansion of cities requires rapid expansion of services, including housing, to prevent epidemics.

3. Housing programs in urban areas generate greater external 
economies, e.g., bettering the health and psyches of industrial workers.

4. 'Probably the most important,' political agitators in urban slum areas find fertile ground for spreading disaffection-better housing may decrease conflict. 3,4

The actual concentration of effort in Costa Rica and El Salvador will be indicated below in Chapter VII.

In much the same manner, arguments are made for emphasizing housing for the poorest classes as opposed to housing for the lowermiddle classes, those who can almost but not quite compete in the general housing market. The basic dispute is between humanity and efficiency. Those arguing for the lowest classes suggest that they need it more, that the lower-middle class will eventually be able to shift for itself; not so for the poorest. The arguments for the lower-middle class hold that they will be able to pay their rent or mortgage, getting money back into the pot for additional housing; that this is the fastest stimulus to an increase in the construction industry, an industry in which the poor could get work and move to the lower-middle class; and that it is simply too expensive to house the lowest classes. Again, the policies chosen by the agencies will be presented below.

Choosing a socioeconomic class to benefit from public housing activity is not sufficiently precise for program purposes. Projects house families, not socioeconomic classes. And again, the families most in need of public housing may be just the ones who do not fit in a project--no skills to finish a self-helf unit, too many children, or problems with contagious disease, for example.

The last set of major considerations that go into the process of making decisions about publicly assisted housing involves financing. 
Financing policy is Janusian: the one face looks outward to the overall financing of the project while the other looks inward to the financing by the inhabitants of their individual shares.

Financing of housing at the macro level is more a search for money than a selection among alternative funding opportunities. A number of major problems constrain and inhibit investment in housing. The wealthy classes in Central America have been traditionally disinclined to make any non-argricultural investments in real estate, save for luxury construction or for speculative purposes. Private entrepreneurs can realize faster and larger returns from other investment opportunities, particularly in an inflationary climate such as that of Costa Rica. National governments do not have the sums of money needed generally available to them. It becomes necessary, therefore, to seek external sources of funding. With external sources of funding come additional participants in the policymaking process, and additional constraints.

Consider, for example, the following provisions which are but some of the restrictions mandated by one external funding agency, Banco Interamericano de Desarollo (BID), on any public housing projects for which it has loaned money. Recipient governments must invest the funds within a set period and make all purchases and let all contracts (except for self-help projects) through public bidding. Relationship of the project to a comprehensive national housing policy musi be specified and self-help must be at a maximum. The project must eventually be self-sustaining. Money loaned must be used for private home ownership and new construction, not for rental units or restoration. Hous- 
ing is to have 'minimal internal amenities' and provision of nonhousing urban infrastructure is prohibited. In short, governments and agencies borrowing to finance housing construction may pay only a very low interest cost but a very high one in loss of freedom to design and institute local housing policy.

Methods provided for owners and renters in public housing facilities to finance their individual shares will not be discussed further here but will be examined below. Chapter VII, then, will present the current character of housing policy, i.e., the set of day-to-day activities resulting from these policy deliberations. Practices to be considered include regulations governing clientele selection, and specific accomplishments--the actual provision of dwelling units. Explicit comparisons among INVU, IVU and FUNDASAL will be offered.

GENERAL MUNICIPAL REVENUE POLICY

Unlike housing policy, municipal revenue raising is very much a local government function in both San José and San Salvador. To be sure, there are in both countries greater (Costa Rica) or lesser (El Salvador) levels of subventions from national to city governments, but the municipalities must raise money on their own. Transfer payments will be considered briefly in the following chapter; here the concentration is upon the processes by which the local governments attempt to increase their own revenues. Initially we examine the general methods for the augmenting of the local governments' own funds, next we examine an unsuccessful attempt to raise taxes in San Salvador and finally we trace the arduous route through which San José was able to 
impose a new charge. In all of these we will concentrate upon activities within the boundaries of the political system.

City councils in San Salvador and San José, like their counterparts worldwide, devote a good bit of their energy to raising enough money to finance a wide variety of municipal services and activities. And like their counterparts elsewhere, their attempts to raise money often meet with stiff resistance.

In both cities, the municipality's own income comes from three sources: patentes or impuestos municipales, tasas and contribuciones. Unfortunately there are no perfect correlations with any of our better known generic terms for municipal revenue sources in North America.

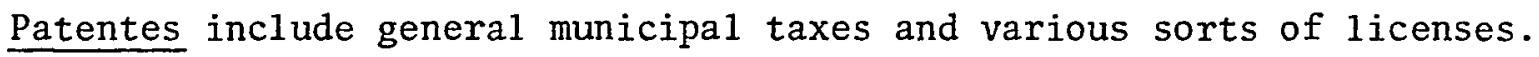
They are charges for the privilege of doing something within the municipal boundaries (e.g., residing, engaging in commerce, carrying a firearm) that does not require any municipal effort or service. Tasas are basically charges for continuing services provided by the municipality as, for example, garbage collection and street cleaning. Contribuciones are charges made for new, usually one-time-only municipal activities such as installing a culvert, paving a street or constructing a sidewalk. Services for which contribuciones are charged are the sorts of improvement which, if provided by municipal governments in Oregon, would likely be Bancroft-bonded.

To further the confusion in terminology, tasas and impuestos are both used freely as generic terms for any government impost or levy. In San Salvador the term arbitrio is often used in place of patente; the two are interchangeable. 
Considering our framework for policy analysis, then, we may assume that the municipal political systems have gathered the whole range of policymaking phases, so far as possible, within their own boundaries. In other words, there may be demands, isolated or aggregated, made upon them from outside for expensive services but the demands for increased revenues to support these services come from within.

Individual councillors, then, may be regarded as the initiating actors in attempts to increase revenue. It should be noted, however, that in some cases, especially in San Salvador, the bureaucracy will make the original demands or recommendations.

In the usual practice, an individual councillor will suggest to council that the rates for a particular charge or tax be raised, or that a specific new source of revenue be adopted. The council discusses the idea and if it is deemed worthy of further consideration it will be assigned to the appropriate committee, the Standing Committee on Budget and Finance in San José and the Interim Finance Committee in San Salvador.

The committee may consider each suggestion on its own, or it may engage in some internal aggregation and assembly a package for council discussion. After due deliberation, the council may decide to pass the increase, to reject it, or to return it to the committee for modification. If the increase is passed, the adoption phase for that particular policy is complete.

Legitimation, in both senses, is the next stage. In both Costa Rica and El Salvador, as stated above, any changes to municipal tax or 
user charge rates as well as any new charges require approval from the Central Government. A definite procedure, then, exists for legitimating (in the legal sense) the revenue policy. Different levels of Central Government approval are required for tasas and contribuciones, whether new or modified, than for patentes. Since the former are simpler, they are discussed first.

When the Municipality of San Salvador passes any new tasa or contribución or makes any rate change therein, the Vo.Bo. of the Ministry of the Interior is required, before the new levy comes into effect. The Municipality first transmits its proposed policy to the Governor of the Department, who in turns transmits it to the Ministry of the Interior. The Governor may comment on the proposal but cannot himself approve or disallow it.

Upon receiving the request, the Ministry assigns it to its Department of Municipal Control. The Department considers the proposal, and may call for such comment from interested parties as it feels appropriate. When it has reached a decision as to the desirability of the policy, the Department reports back to the Minister with its recommendation. (Sometimes the policy proposal just disappears; the Department of Municipal Control is widely regarded as a graveyard for dead municipal rate increases.)

The Minister of the Interior is not bound by the recommendation of the Department; he is perfectly free to approve or disapprove the policy. If he approves, he so informs the Department Governor who in turn informs the Municipality. At this point the Municipality must publish the policy proposal, in both the Official Journal and a news- 
paper of general. circulation, thrice at intervals of not less than one working day. Then, and only then, can the Municipality begin to implement its new revenue policy.

The policy process in San José is parallel but somewhat simpler. Again, the policy suggestion passes from individual councillor (or from the bureaucracy) to the complete Council, thence to the Standing Committee on Budget and Finance and thence back to the full Council for its approval.

In Costa Rica too, Central Government approval of changes in

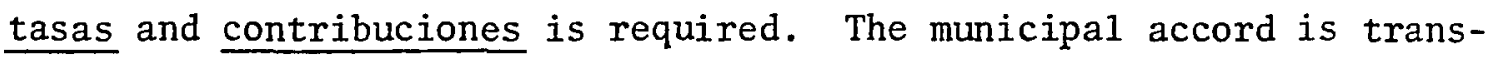
mitted to the Comptroller General of the Republic. Within this office, the policy is analyzed by the Department of Economic Studies which makes a recommendation to the Comptroller. If the Comptroller approves, he publishes the document in the Official Journal. Eight days after publication, the Municipality may commence application of its new policy.

In both countries, the process for instituting new policy in the realm of municipal impuestos (arbitrios, patentes) is even more complex than that for tasas and contribuciones. Aggregation, formulation and adoption procedures remain the same but another formal actor enters the legitimation phase. Changes in the structure of the impuestos require approval not only of the executive power of the central governments but also of their legislatures.

In El Salvador, the impuesto policy, like the tasa/contribucion policy, is transmitted through the Department Governor to the Ministry of the Interior. After study by the ministry's Department of Munici- 
pal Control, it is returned to the Minister who sends it to the presiding officer of the Legislative Assembly for introduction to that body.

After brief initial consideration, the Assembly assigns the bill to its Committee on Interior and Public Works which considers it and returns it to the full Assembly for discussion there. If approved by the Assembly, the policy filters down as before to the municipality for application.

In Costa Rica, municipal impuesto policy is transmitted in the same manner as tasa policy up to the point where the Comptroller General makes his recommendation thereon. From here it goes to the Minister of Government who in turn sends it to the President of the Assembly for introduction. The Assembly assigns it to the Committee on Social Affairs (Asuntos Varios) for study and recommendations. If the full Assembly passes the bill on its return from Committee, it is sent to the President of the Republic for approval, and he causes it to be published in the Official Journal. Again, after the eight-day waiting period, the municipality may begin implementing the policy.

The policy that the municipality can now execute may not be precisely the same as the one it adopted. Both national legislatures have the right to modify as well as reject the municipal policy proposal. If the modifications are not to the municipality's liking, it either has to live with them or not proceed with the policy implementation stage.

Concurrently with the formal, legal legitimation process for the municipal revenue policy, the informal legitimation takes place. Sel- 
dom are policies to raise tax or user charge rates, or to institute new ones, universally popular. In Costa Rica and El Salvador it is generally during this phase that the affected interests attempt to have the policies disallowed or at least the more objectionable features changed. It is, therefore, the primary point of access for informal policymakers. Both types of informal policymakers, as identified in Chapter III, can be found here.

Municipal officials are not content to await deliberations on the fate of their policy proposals. They lobby for them in the same way as other interest groups. Generally, municipal officials are the only actors seeking favorable consideration for new or higher taxes. As lobbyists, municipal officials are proximate policymakers acting outside their prescribed roles and are therefore regarded as informal rather than formal policy participants.

In opposition to the increased levies are whichever groups will be paying the bill. In many cases this is their first chance to influence the legislation. Many of these individuals and groups routinely deal with the central governments and make effective use of 7

their contacts. Specific examples are provided below as we examine attempts at major tax reform in San Salvador.

It was expected that the legitimation process would be much smoother and more pro forma in Costa Rica than in El Salvador. After a11, the Costa Rican Legislative Assembly and the San José Municipal Council had the same sort of partisan make-up. Presumably, then, the bitter political and ideological strife that exists between San Salvador and El Salvador would be absent. Legitimation thus would be 
much more likely for tax increases in San José than in San Salvador.

In neither case, however, did the municipalities meet with much success in having their revenue policies approved. Other municipalities in both countries had new taxes and rate structure changes approved rather routinely but not the capitals. San José had not had a new tax approved since 1935 and San Salvador's tariff schedule had remained unaltered since it was first adopted in $1947 .{ }^{9}$ The researcher, then, who is attempting to select one particular tax policy to trace in great detail is faced with a major problem--the lack of any policy that could be examined from perception through application. It was decided therefore to discuss briefly a policy that failed in the legitimation phase in San Salvador and to examine more closely the most successful example available in San José.

\section{SAN SALVADOR - TAX REFORM AND HOW IT FAILED}

Since it came to power in San Salvador in 1964, the Christian Democratic Party has attempted to overhaul the city's archaic and 10

chaotic tax structure. A variety of motives underly these efforts; it is inappropriate to discuss them here. What is examined in this section is the policy process associated with these attempts, and its ultimate breakdown.

The basic objectives of the tax reform were twofold: one, to increase the amount of municipal revenue; and two, to shift the incidence of much of the tax burden from smaller to larger enterprises. This latter action would not only serve the political end of pleasing PDC's small merchant supporters but also the administrative end of in- 
creasing tax collection efficiency.

To provide a sample of the nihilistic state of the existing tax structure and the order of reform attempted by the municipality two short examples follow. The only categorization, the only order, is purely alphabetical; there is no attempt to group similar sorts of activities. The first ten entries in the Tarifa read thus (amounts are monthly charges in $\$$ C.A.):

TABLE XX

\section{EXCERPT FROM SAN SALVADOR TARIFF STRUCTURE}

Concept

Fire Insurance Agencies

Air Transportation Agencies

Foreign Life Insurance Agencies

Steamship Agencies

Agencies of Foreign Commercial Houses

Oil Company Agencies

Gasoline Company Agencies

Soap Company Agencies

First Class Automobile Sales Agencies

(capitalized at over $\$ 20,000$ )

Second Class Automobile Agencies

(capitalized at over $\$ 20,000$ )
Total

$\$ 78.00$

$\$ 100.00$

$\$ 52.00$

$\$ 78.00$

$\$ 16.00$

$\$ 40.00$

$\$ 100.00$

$\$ 4.00$

$\$ 15.60$

$\$ 7.80$

SOURCE: Tarifa de Arbitrios de la Municipalidad de San Salvador.

It can readily be seen that categories such as 'agency' or 'factory' contain large numbers of listings in no useful pattern. Shrewd businessmen can and do simply pick and pay for their least heavily taxed commercial activity.

San Salvador's proposed tax policy provided far more order. In one section, for example, it gathered together financial institutions--private banks, branches of foreign banks, savings and loan as- 
sociations, stock brokers, insurance companies, finance companies and pawnbrokers. Under the 1947 Tarifa some of these paid no municipal tax; others paid amounts ranging from $\$ 13.00$ to $\$ 78.00$ per month, regardless of size. To complicate matters still further, they were listed under seven different headings on as many pages. Under the reformed policy, 20 categories were created according to the amount of capitalization. The smallest business would pay $\$ 8.00$ per month under the new schedule; the largest $\$ 390.00$ plus one peso for every $\$ 200,000$ of capitalization over $\$ 40$ million. Financially and administratively, then, the new policy made eminently good sense from the Municipality's point of view.

The City Council realized that any tax reform policy it adopted would not go unquestioned by those who would bear the brunt of the tax. Consequently it began attempts at informal legitimation even before the formal process. In October, 1964, the municipality met with the Cámara de Comercio e Industria de El Salvador (CACI) and presented, in general terms, its proposed policy. CACI indicated that it recognized the need for a new municipal tax policy and would not oppose one that did not unjustly oppress its members and friends.

The Municipality continued with its policy formulation, and adopted and transmitted to the Legislature its request in March 1965. The Municipality had not discussed the policy details with CACI and the latter group was quite unhappy with them. Its immediate response was the formation of a junta with the Asociacion Salvadoreña de Industriales (ASI) and other affected groups to oppose the new policy. The junta's attempts to abort the policy in the legitimation 
phase involved both the formal and the informal legitimation. On the informal side CACI and allies began a widespread media attack on the policy. Among other disastrous results of the policy's implementation, it was alleged, would be the ruining of the larger businesses most impacted by the new taxes and massive price hikes to poor shoppers, the ultimate consumers of the tax increase. Moreover, the junta suggested, the Municipality's fiscal problems were primarily a result of its own administrative ineptness (or political chicanery) in not collecting the revenues to which it was currently entitled. The new policy included greatly increased levies on bars, go-go joints, dancehalls and billiard parlors. The junta insisted this was an improper attempt to use a fiscal instrument, a tax policy, for a non-fiscal purpose, i.e., the imposition of a particular moral standard on the community.

Formal attempts to block legitimation occurred in two arenas. The business sector used its two seats on CONAPLAN as a springboard for trying to convince the Executive Power that the new municipal tax policy, if allowed, would endanger the national policy of comnerical and industrial development. Not only, it was suggested, would this harm the nation economically but would also tend to damage PCN politically.

In the legislative arena, CACI and the junta sought and were granted permission to present arguments to the Committee on Interior and Public Works in opposition to the policy. CACI then requested from the municipality seven types of information it said were necessary to adequately respond to the new tax structure. These were: 
1. a detailed breakdown of revenues received by category of tax;

2. detailed data on expenditures by category of service, distinguishing between expenditures for service and for administration;

3. detailed data on the causes of the municipal deficits;

4. specific estimates of new revenues by categories of tax;

5. a detailed plan for investment of the projected new revenues;

6. detailed data on uncollected taxes;

7. projected plans for administrative reform of the municipal government. $12^{2}$

Needless to say, the nature of the municipal revenue system effective1y precluded the assembling of this information. Nonetheless, the Mayor of San Salvador asked the junta to meet with him, saying he would then provide the needed data. The junta refused, announcing that it would get the information when it was provided to the Legislative Committee. The Municipality did not, could not, provide the information and the National Assembly adjourned without acting on San Salvador's proposed tax policy.

Ten years later there still had been no major changes in San Salvador's tax structure. In 1971 the Municipality modified its policy proposal but once again it did not meet with the approval of the National Assembly; once again the policy died in the legitimation stage.

PDC's financial program for 1974-1977 concentrated on better administrative procedures, special lines of credit from the Central Bank, transformation of some unspecified municipal services into profitable 
enterprises and obtaining of permission to charge National Government agencies for services rendered. Interestingly enough, overall tax reform was not mentioned.

San Salvador's new revenue policy, then, was never implemented. The process ended in the legitimation phase. In this case, informal and formal legitimation appear to go hand-in-hand; failure to obtain the one almost guarantees failure to obtain the other.

It may be useful here to conduct a post mortem on the dead tax reform policy. Not only might we determine the causes of this particular policy fatality, we might also be able to generalize and perhaps suggest some preventative activity for future municipal policy proposals.

Once again dominating the policy failure is the statutory requirement for National Government approval of municipal tax changes. If formal legitimation of this type were not required, there would be no chance for disallowal.

This requirement is particularly lethal to municipal policy in the situation where political and ideological emnity exists between the PDC Government of San Salvador and the PCN-dominated Central Government. Exacerbating the situation in this particular case was the opposition to the Mayor of San Salvador personally. The tax reform was the brainchild of Napoleon Duarte, a charismatic figure known nationwide and generally regarded as having a very good chance of becoming El Salvador's first PDC President in recent years. He could not be allowed this triumph.

Not only is the Municipality at odds politically with the Na- 
tional Government, it is weak vis-a-vis the business community. The private sector has two seats on CONAPLAN representing basically the largest firms; the municipalities have no seats. Moreover, CACI and its allies have more technical and financial expertise than has San Salvador. Any contest between the two, therefore, is extreme1y unequal and very likely to be won by the business interests.

Not all the Municipality's problems, however, arise from the political and institutional stacking of the deck against it. Some of the problems are of its own making. In failing to keep CACI informed as the details of the policy were being drawn up, it may have unnecessarily antagonized them. In addition, the charges of administrative ineptitude in tax collection leveled against the Municipality are undeniably true. The city is definitely in a no-win situation: it cannot reorganize its fiscal procedures until it gets some additional revenue, some breathing room and Central Government approval; this approval will not be forthcoming until San Salvador gets its fiscal house in order.

It must be noted that San Salvador is not totally without allies, at least potential ones, at the national government level. The Municipality's political capital is definitely limited though, and it must be spent prudently. The City was not willing to wage all-out war against either Central Government or the business community; other matters were coming up on which it would be looking for their support. 15

For a variety of reasons, then, the policymaking process in this particular case was aborted in the legitimation phase. Partisan poli- 
tics, intense lobbying and some errors on the part of the municipality all contributed to its failure. There is no doubt, however, that this policy will be resurrected in one form or another. San Salvador's need for additional revenue is not ended, nor are attempts at formulating and implementing policy to provide this revenue.

THE PARKING METER COMES TO SAN JOSE

The parking meter was invented by Carl Magee in 0klahoma City in 16

1932. Since then it has been adopted globally both as an instrument of traffic control and as a source of revenue, particularly municipal revenue. Most cities of any size, U.S. or foreign, have their downtown streets lined with parking meters. San José is no exception. In this section we examine the process by which parking meter policy in San José came into existence.

In the early 1950s San José was growing rapidly. The rapid growth was accompanied by an expanded flow of truck and automobile traffic and the attendant increase in congestion. One effect of this was inconvenience to the customers attempting to park near a downtown book and printing shop, Librería Universal. The proprietor, Hubert Federspie1, approached the Municipal Executive about the problem and suggested the installation of parking meters.

Shortly before Christmas, 1954, Federspiel wrote the Bogotá agent of Magee-Hale-Park-0-Meter Company asking about the availability 19

of parking meters. The agent responded on January 5, 1955 saying that the meters could be shipped immediately from Panamá to San José and suggesting that the Municipality begin marking the streets and in- 
stalling the bases for the meters. Federspiel forwarded the letter to the Municipal Executive; the demand had formally entered the political system.

The Executive forwarded the request and the agent's letter for the consideration of the City Engineer. Two months later the Engineer replied and reported that after consulting the Director of Transit (a Central Government official), it was decided that the installation of private parking meters could not be allowed. However, he continued, the idea of parking meters should be studied.

Less than two weeks later a solicitation for bids to supply the Municipality with 400 automatic parking meters appeared in the offi22

cial Journal. The bids were to be for the meters and installation and were to indicate the price C.I.F. Limon or Puntarenas. The meters were not to be purchased outright by San José but were to be operated on a profit-sharing arrangement between the Municipality and the supplier for five years, after which time the Municipality would assume ownership. Users of metered parking spaces would be charged 50 céntimos per hour or ten céntimos for 12 minutes.

Bids were opened on April 21, 1955, and were considered. At its meeting of July 22, the Municipal Council, acting on the advice of the Auditor, rejected all bids. The Municipal Executive was authorized to draw up a more specific solicitation and reopen the bidding. There was no discussion.

It is useful to consider the phases of the paradigmatic policy process to this point, the actors involved, and the roles played. Initial perception of an environmental condition and its definition as a 
need or problem were done outside the political system by an individual. The matter of the parking meter was considered strong enough to stand by itself; it was not aggregated with similar issues. Hubert Federspiel then made a demand of the political system and the process entered the government phase. 24 Formulation of the initial policy was done by the bureaucracy and the policy passed to the Council for adoption. It failed at the adoption phase and was returned through a feedback loop for reformulation.

A more detailed specification package was assembled by the Executive and the official call for bids was made in October, 1955. The most fundamental change from the earlier solicitation was that the more recent one sought bids for the outright sale of the parking meters to the Municipality. Bids were opened on October 31 and the Municipal Council considered them at its February 29, 1956, session. It was decided to award the contract to Jaime Güell and Company representing the Duncan Meter Corporation of Chicago. A clause was written into the authorizing ordinance to the effect that:

It is intended that this award will become effective immediately the Legislative Assembly authorizes the imposition of the tax that takes place with the installation of the parking meters and as soon as the Comptroller General of the Republic approves the supplemental budget. 26

The policy, however, was never presented to the Legislature for enactment as law nor to the Comptroller for approval of the budget changes. No further official comment was made on the matter for almost two years.

Parking meter policy reappeared with another solicitation for 27 bids in the Offical Journal during July, 1957. Other than requiring 
the meters to be automatic rather than manually operated, the specifications were the same as in the previous solicitation. Bids were opened that same month and went to the Council's Joint Committee (Finance and Public Works) on Parking Meters.

The Committee reported back to the Council at a special meeting in November. At that meeting the Municipal Executive referred, somewhat obliquely, to the fate of the previous parking meter ordinance:

You romcriber lián soñe 2 si 3 years ago we introduced the matter of parking meters . . . and through one circumstance or another we have had to vacate the solicitations.. . the last time they made us a very good offer that did not require any down payment by the Municipality but this [the current offer] is an investment that pays for itself and is a better deal for the Municipality . . . and then as now what we have to look for is the benefit of the Municipality ... 28

Nothing more was said of the earlier policy attempt.

The Council proceeded to discuss the bids before it. The lowest bid was from the Maico Company but the Committee recommended against accepting it. Panamá had used these meters for a while but had switched. Therefore, it was implied (but never stated), they must be unsuited for use in Central America. Moreover, it was argued, they were German made and solving any problems with meters from so far away would be both inconvenient and expensive.

Unlike the earlier meetings on this subject, debate at this one was intense and wide ranging. One councillor argued, for example, that if Costa Rica was trying to sell its coffee in Germany, surely a Costa Rican municipality could buy a German parking meter. Another councillor pointed out that the Comptroller was not likely to approve the purchase of any meters but the cheapest. 30 The Municipal 
Executive responded that because the lowest bid required a larger down payment and charged the Municipality interest on the unpaid balance, it really was not as low as it seemed and he could persuade the Comptroller to accede to the Municipality's wishes.

Finally the Council decided, as before, to award the contract to Jaime Güell for Duncan parking meters. Then came discussion of the mechanics of the purchase, specifically, obtaining necessary Central Government approval, and arranging the financing. Financing arrangements with the company were simple and readily agreed upon: ten percent down, the rest in 12 equal monthly installments. Two other financial matters were not so simple: the Municipality had to petition the Central Bank for permission to buy U.S. dollars for the transaction and the Minister of Finance for exemption from customs duties. Once again the question of Central Government approval arose. This time, however, it was suggested that only the Executive Power and not the Legislative Assembly need legitimate the policy. The City's Legal officer suggested that asking the Assembly for enabling legislation was an imposition on that overworked body. Further, it was unlikely the Assembly could consider the request within the 120 days specified for closing the contract. Moreover, he was of the opinion that the parking meter fee was a tasa, not an impuesto; the legislative Vo.Bo., then, was unnecessary.

He was supported in this position by the Municipal Executive who pointed out that there were existing laws controlling traffic and parking. In addition, charges were levied, in the guise of fines, against those who currently overparked in controlled zones. There- 
fore, he concluded, no further legislation was needed, only the approval of the Comptroller.

These municipal officials had not reached their conclusions in a vacuum. Conversations had been held between them and functionaries of the Comptroller and of the Ministry of Transportation, as well as with Deputies of various parties. The Council was convinced, and passed the ordinance making the award to Giell with the stipulation that approval of the Comptroller was needed to legally bind the contract.

Such approval was not forthcoming; some two months later the Comptroller voided the contract. The directive from his office read:

CONSIDERING: The Comptroller estimates that the functioning of parking meters in the City of San José, with the purposes of regulating the parking of vehicles in the public ways through the medium of paying the Municipality for the right, constitutes a tax [impuesto], and since it is not logical to authorize the purchase of the apparatus prior to approval on the part of the Legislative Assembly. THEREFORE: The resolution passed by the Municipality of San José is declared nul1. 31

Once again the purchase of parking meters was stymied.

At the next City Council meeting, the Municipal Executive ques32 tioned the action of the Comptroller. Why, he wondered, had the Comptroller said nothing when any of the three solicitations for bids appeared in the Official Journal? Moreover, the Executive asked, was there any connection with a letter to the Comptroller from a disappointed bidder claiming that his firm had actually submitted the lowest bid, that factors not taken into account made it the best, that no interest would be charged the Municipality and that their meters were 33

of very good quality? Was not the Comptroller, the Executive continued, actually saying "The parking meter of $\mathrm{Mr}$. Maroto is effec- 
tively the cheapest. Consequently the award is being revoked and presented to Mr. Maroto"? If so, this was not a valid exercise of the Comptroller's power.

Various members of the Council expressed agreement with the Executive. Regardless of right and wrong, however, the Comptroller had the power to block the purchase. The Council formed a committee to present its viewpoint as forcefully as possible to the Comptroller. The committee was to meet with the Comptroller and ask him to rescind his resolution.

The committee met with the Comptroller and put forward its case. The Comptroller was not impressed. After almost a year of arguing that the parking meter charge was a tasa and not an impuesto, the Municipality capitulated. The Finance Committee and the Municipal Executive reformulated the policy, which was adopted by the Council 34

without discussion or debate, and forwarded it to the Executive Power for transmittal to the Assembly.

Two important changes appeared in this new version of the policy proposal: one, it was presented as primarily a traffic control and public security measure, with municipal revenue as a secondary consideration; and two, it stated that half the proceeds from fines levied against non-paying parkers would go to the Director General of Transit, an arm of the Central Government.

After four months of study by the Comptroller and other interested officials of the Executive Power, the project was submitted to 35

the Legislative Assembly on July 9, 1959. The full Assembly assigned it to the Interim Committee on Taxes and Municipal Enterprises. The 
Committee considered the proposal and decided to seek some outside expertise. Oñ Gctútei 28 the Committee secretary wrote the Director General of Transit seeking his advice, suggestions and criteria for 36

putting the policy into operation.

Nothing happened. Nine months later the Municipal Executive

wrote to the Chief Clerk of the Legislative Assembly:

It has been over a year now since the Minister of Government sent the Secretary of the Legislative Assembly the project. As, in reality, I am ignorant of reason as to why said project has not been submitted for the consideration of the honorable Assembly, I would very much appreciate your informing me in this respect. 37

For once, a timely reply was forthcoming. Less than a week later the Chief Clerk answered:

Allow me to inform you that the project to which you refer does not have a recommendation [from the Committee]. Moreover, as the said project was presented in the past Legislature, and in this [one] no Deputy has asked that it be brought to the floor, permit me to suggest that it would be to your convenience to ask some Deputy to make such a mo-

No such Deputy was found.

In April, 1961 the Municipality found itself in financial difficulties of undetermined magnitude. Two Councillors suggested a hard look at the state of the municipal fisc. This task was assigned to 39

the Committee on Finance and Budget. The Committee reported back at the next meeting with the disturbing news that projected revenues for the year would fall short of projected expenditures by $\$ 1,757,281.48$.

The Committee suggested that the shortage was due to an insufficiently progressive tax structure. No one, however, was willing to introduce changes. The Council decided to tighten its belt, cut down 
on the use of municipally owned vehicles by councillors, sell a number of small municipally owned lots and seek new sources of revenue.

Two months later Councillor Carlós Larín Angulo brought up park40

ing meters at a council meeting. He presented an already written ordinance and it was adopted unanimously, with no discussion.

This version of the policy proposal contained a number of new provisions. In the preamble, for example, it stated that the Municipality was seeking to cooperate with the Director General of Transit in managing traffic and parking and to do this by the use of the most modern technical and scientific methods, had decided to install parking meters. In a radical shift of direction the preamble went on to say that day-care centers were needed in San José and that the Children's Asylum and Orphan's Hospital were worthy institutions and would receive money from the proceeds of the parking meters. Other money would go for road upkeep, benefiting motorists who fed the parking meters, and for sanitation works.

This something-for-everyone accord was transmitted to the Executive Power for submission to the Legislature. On July 3 the Minister of Government forwarded it to the Assembly, where it was officially received on July 5. The Assembly wasted no time in deciding it was going to shelve the proposal and rather curtly informed the Minister of this:

. . we have resolved to remove from the consideration of this Assembly the projected law presented by the Municipality of San José and intended to authorize the installation of parking meters. 41

At this point, then, the parking meter policy, if not dead, was at 
least moribund.

Outside the Legislature, however, a variety of activities relating to the parking meter policy was occurring. In San José, two Councillors asked the Municipality to give the Little Sisters of the Poor of St. Peter Claver a continuing grant of $\$ 500$ per month to help them with their day-care center. The Council passed the request to the Committee on Finance and Budget. The Committee reported back to Council and the Council passed a motion saying in effect:

It is a great idea, the Sisters do wonderful work, but the Municipality just cannot afford it. If, however, the Legislature would act on Larín Angulo's parking meter proposal, a considerable sum of money could be destined for construction and maintenance of day care centers. . . In any event, the Committee is happily studying the matter for 1962 in case the Assembly does not approve our project. ${ }^{43}$

Once again the Central Government was informed of the Municipality's request. Once again nothing happened.

During the spring and summer of 1962 INVU conducted a superficial survey of traffic flows for San José and for other cities, with an eye to using the results in choosing locations for housing projects. The Municipality used this information to buttress its case and once more requested legislative approval for its parking meter policy. No changes were made in the project, only a request, accompanied by the INVU material, for a reconsideration of its proposal. The Executive Power transmitted the request to the Legislature; it was not heard of again.

In the meantime traffic congestion and parking problems continued to increase and plague downtown San José. The City Road Depart- 
ment undertook to study just how severe the difficulty was and to quantify its magnitude. This work continued for two years and in February, 1965, the 'Plan for the Regulation of Parking in the Central Area of San José' was proposed by the Technical Branch of the Road Department. Among its findings were the amount of vehicle traffic $(100,000$ vehicle trips per day), average length of parking time for various groups, needed dimensions for convenient parking space and total number of regulated parking spaces. Among its recommendations were wider streets, more signal lights, no parking along bus routes and a more extensive zone of limited time parking--controlled by parking meters.

The Municipal Executive took advantage of the information and recommendations in the plan to support his plea for reconsideration of the parking meter project by the Legislature. In July he wrote to the President of the Assembly:

The projected parking meter 1 aw is buried in the Legislative Assembly. This bothers me and a number of the councillors, especially Carlós Larín for it would enable us to regulate the use of our congested ways and at the same time provide some funds for street repair and maintenance. . . We have 2,147 parking spaces in the central area and want meters on them . . . It is certain, Mr. President, that if you reintroduce for discussion the projected Parking Meter Law for the municipalities of Costa Rica, you would receive the gratitude of all the Councils in the country. 44

One modification of singular importance is suggested in this letter. No longer is the request to the Legislature for the approval of a policy for San José but for all the municipalities of the country.

The President of the Assembly was convinced. The next day he 45 reintroduced the project into the Assembly. In his preamble to the 
bill he pointed out that the project, originally sent to the Assembly on October 17, 1962, had undergone two major changes: one, it was now presented as primarily a congestion relief rather than a revenue measure; and two, it was to cover all the municipalities of the country, not only San José.

For the first time, the Legislature considered the policy proposal seriously. The Committee on Social Affairs studied the bill and with only one minor change reported it back to the full Assembly with a favorable recommendation on September 27 . One other minor change was made on the floor. (A second amendment, trying to lower the hourly charges, was defeated.) The Assembly passed the bill on 0ctober 6 and sent it to the Executive Branch where it received the approval of the President of the Republic on November 2, 1965.46 The formal legitimation phase was complete.

Once again the Municipality prepared to solicit bids; this time with the assurance the Central Government would not declare the bidding nul1. On January 5, 1966, the call went out for bids to supply 2,000 parking meters. Bids were to be opened on February 8 .

The Municipality had made a number of changes and refinements in its requirements since the last abortive effort to purchase meters. Potential bidders requested more than the allotted time to prepare their new offers. Consequently, the Municipality received no accept. able bids by the closing date.

At this point the Municipality began to consider the structure of its bid solicitation more closely. Particularly, it began to consider what technical specifications it actually wanted in a parking 
meter. For example, some previous solicitations had required automatic meters and some had required manual meters, with no particular rationale in either case. With the political concerns about the parking meters taken care of, San José decided to allow itself the luxury of taking the time to determine precisely what mechanical features the apparatus ought to have. This would not only ensure the Municipality obtaining the meter best suited to its needs but would also enable it to prepare a detailed enough specification list that potential suppliers could prepare reasonably costed bids.

The President of the Council assigned to the Committee on Transit and Urbanism the task of studying the various meters available and determining exactly what specifications to include in the next bid notice. One of the Committee's first activities was an examination of the parking meter operations in other cities. The three cities most closely investigated were Panamá and Guatemala, where climatic conditions were similar to those in San José, and Portland, Oregon, which had a long history of successful parking meter operation.

For a city that had been in such a hurry, time and time again, to rush its parking meter policy through both Council and Central Government, San José seemed singularly unconcerned with actually putting the meters into operation. The study phase lasted over four years; not until October, 1970, did the call for bids go out.

Bids were opened on January 20, 1971, and were sent to the Joint Committee on Transit, Urbanism, Finance and Budget. The Committee made its recommendation to Council two weeks later. The Council by a vote of 13 to one awarded the contract to Enrique Herrero y Compañia 
for 500 Duncan parking meters at a cost of $\$ 41,065$. This time, finally, the contract was fulfilled.

On July 7, 1971, the Municipality published the regulations governing parking meter use. They would be in operation from 6 A.M. to 6 P.M. Monday through Saturday, would cost parkers one colon per hour (twice the rate originally suggested), and only diplomatic personnel would be permitted to park free.

The final, legal, official enabling activity took place in October when President José Figueres promulgated an executive decree 50 authorizing the regulations.

Although unusually heavy summer rains had forced some delays in the parking meter installation, 380 were in place by November. As part of the celebration marking the beginning of National Guard Week, the first parking meters went into operation at 6 A.M., November 8 , 1971. It was 16 years, nine months and one day since Hubert Federspiel's letter to the Municipal Executive had injected the demand for a parking meter policy into the political system.

As was the case in San Salvador, the major difficulty in creating this policy lay not in the formulation/adoption phase where the Municipality was the chief actor but in the legitimation phase, controlled by the Central Govermment. It is worthwhile to examine those modifications that took place in the original policy proposal and led to the policy's ultimate approval by the Central Government.

One factor had to be the increasing specificity of the proposal and its support from hard data. The original policy called for 400 meters; no specifications of any kind were either required or sug- 
gested, nor was there any indication as to what uses the income derived therefrom might be put. The proposal as approved contained detailed specifications on both matters. The original policy contained no traffic count, no estimate of number of parking spaces, no indication as to what sorts of people parked in the city center, for how long or for what purposes. Information was provided on all these aspects for the approved policy.

Another change in the policy which influenced its ultimate legitimation was its shift in emphasis. As originally proposed by the Municipality it was strictly a revenue raising policy. As finally approved it was a policy for controlling parking and relieving traffic congestion, a policy that only coincidentally generated some funds for San José--or at least so it was perceived.

Probably the most important factor leading to the parking meter policy's success in the Legislature was the broadening of its scope. As a lone policy suggestion it had little appeal to the Central Government, either the Assembly or the Executive. As part of a larger policy for improving traffic circulation it was much more attractive. Above a11, the Central Government was reluctant to legitimate any policy that would benefit only the Municipality of San José; it proved far more receptive to a policy that could be applied in all the cities of Costa Rica.

Two unsuccessful elements of the Municipality's legitimation strategy might also be mentioned here. San José attempted to both shame and bribe the Central Government into approving its policy; neither approach worked. The Municipality tried to make the Central 
Government feel guilty about the lack of funds for the so deserving child-care programs. The effort failed, as did the attempt to bribe by designating some of the parking meter proceeds for the Director General of Transit.

Ultimately, then, the Central Government was willing to approve a detailed policy, backed by hard data, that would enable the municipalities of the country to control traffic flows in their downtown areas. It was not willing to approve a vague policy designed to fill the municipal coffers of San José.

With the parking meters in place and the regulations in force, the bulk of the policy process was complete. Only marginal adjustments remained, either to iron out unforeseen bugs or to respond to public feedback. Initial public feedback was widespread.

For the first few days after the parking meter policy went into effect it was a major newsmaker in San José. On November 9, La Prensa Libre reported that 450 tickets had been issued the first day for 51 failure to plug the meters. The article suggested that it was partly the Municipality's fault; it had failed to instruct the populace on the mechanics of how to operate a parking meter. The same day La Nacion reported that there were fewer automobiles on the streets and that therefore one of the objectives of the parking meter policy 52

was being met. The same article mentioned that to ensure payment of fines, the authorities would remove license plates of those cars illegally parked, with the plates to be returned only when the fine was paid.

The next day La Nacion headlined its article "Easily Evaded are 
the Parking Meters" and indicated a certain insufficiency of enforcement on the part of the Municipality. ${ }^{53}$ La Prensa Libre wrote of a social problem caused by the meters; the fact that car parkers were robbed of their living. 54 The particular object of this journalistic concern was one Francisco Mora Campos who had been supporting a wife and three children on the $\$ 150$ per week he had been earning as a car parker.

The following day was a slow one for parking meter news. The Municipality did publish a note on how and where to pay fines but there were no news stories or editorial comments. On the twelfth of November, however, things picked up. An unidentified 'Lover of Progress' wrote to the editor of La Nacion praising the meters and the Municipality for installing them, while the editor himself opined: "We believe that the initiative of the Municipal Corporation merits 55

applause." More interestingly, La Prensa Libre announced a protest march against the parking meters by collectors and messengers. 56,57

It should be noted here that this protest was one of the very few manifestations of public disapproval of the parking meters. (Cyclists, objecting to paying the same amount as automobiles for metered parking spaces, had earlier protested.) If those who parked in the central area were strongly opposed to thus paying for it, they were not saying so publicly. With no major actual or perceived local opposition to the policy, the Municipality felt little need to publicize, explain or justify it. Informal legitimation, therefore, took place almost automatically.

The Municipal Corporation was delighted with the performance of 
its parking meters. A month after they first went into operation, it gave Enrique Herrero y Compañia an order for another 500 meters. In their first four weeks, parking meters had grossed $\$ 92,000$ exclusive 58 of fines.

A second lot of parking meters was purchased and installed. There was no debate at the Council meeting, no objections from the Central Government and no public protest. The adoption, legitimation and implementation phases of parking meter policy appeared to have become routinized.

In May, 1973 the Council discussed parking meters once again. Two factors dominated the discussion: the nature of the general argument on the need for more meters, and Councillor Chavez Molina's impassioned pleas against them. One reason put forward for the purchase and installation of new meters was consistency in parking regulation. Meters were currently functioning in the center of downtown and on the fringes; in the space between were gaps, overcrowded areas of free parking. These areas should, logically, be metered. A more important reason was the financial one. The City needed the money and had lots of places to put meters where none were then installed. It should be emphasized that with the exception of Chavez Molina there was no question as to whether there should be any more meters, only as to how many and where they should go. One argument advanced for inmediate purchase of 1,000 was the rising cost of iron and steel which would surely be reflected in higher future prices for the machines.

Chavez Molina's arguments against the purchase of parking meters 
were surprisingly intense and wide ranging. In the first place, he suggested, Costa Rica's foreign exchange was very hard earned by the sales of millions of pounds of milk products and coffee. It should not be squandered on "North American gadgets so San José can enjoy the 60

luxury of playing big city." Further, iron and steel prices might be going up but these materials were not used in the parking meters. Moreover, the United States, in a deliberate attempt to destroy the economies of Bolivia and Chile, was cornering the world markets in tin and copper. When they released their stockpiles of these materials, used in parking meter construction, the cost was bound to go down. Finally, at least in part because of the perfidy mentioned above, the U.S. dollar was going to decline in value against the colon. Not until this happened should the Municipality consider purchasing any parking meters. Chavez Molina's arguments availed nothing. The Council, over his lone dissenting vote, decided to buy another 1,000 meters.

The parking meter has come to San José and become institutionalized. It is there, moreover, primarily as a revenue raising device. When municipal officials were asked how well the parking meter policy was working they inevitably replied: "Very well. They are making lots of money for the Municipal Corporation." Not once did an official volunteer any comments about traffic control.

As a revenue generator the parking meter has been successful, as shown in Table XXI. Table XXII shows the 1974 budget estimated income and expenditures for the parking meters. 
TABLE XXI

PROCEEDS OF PARKING METER OPERATIONS, 1971-1973

Year Amount collected from parking meter operations, exclusive of fines

1971

1972

$\$ 135,355.75$ (8 November - 31 December)

1973 $\$ 931,136.85$

$\$ 1,080,961.45$

SOURCE: Municipality of San José, Office of the Treasurer.

TABLE XXII

ESTIMATED PARKING METER REVENUE - 1974

Income

Parking fees

Fines

Tota 1

Expenditures

Current

1,000 New Meters

Total

$$
\begin{array}{r}
\$ 2,203,530.00 \\
375,840.00 \\
\hline \$ 2,579,370.00
\end{array}
$$$$
\begin{array}{r}
\$ 976,871.80 \\
135,383.50 \\
\$ 1,112,255.30
\end{array}
$$

Net Income

$\$ 1,467,114.70$

SOURCE: Municipality of San José, 1974 Budget

To put the parking meter revenues in perspective, 7.6 percent of the current income of the Municipality of San Jose comes from this 61

source. The Parking Meter Division employs some 95 persons; only the Streetcleaning and Garbage Collection Divisions have more employees.

The development of parking meter policy may not seem a terribly exciting subject of examination, but it is important for a number of reasons. It is important to San José because it was the first new tax it was able to levy in over 35 years. The parking meter generates 
the second largest amount of revenue of the City's own sources. And it does provide a means, although this is definitely a secondary consideration, of influencing traffic circulation in the downtown area. It is also important to the analyst. In the first place, it is the only municipal policy of the past 40 years that can be traced through from its genesis to its implementation. Second, it shows the sort of time frame in which policymaking takes place. Finally, it demonstrates the overarching role of the legitimation phase in policymaking in a Central American urban center.

The next chapter will present the results of the total policymaking effort, national and municipal, in the realms of urban public finance and public housing; that is, the current set of practices and regulations in San José and San Salvador will be examined and compared. 
CHAPTER VI NOTES

1. Koth, Housing in Latin America, p. 100.

2. Gustavo A. Antonini, Public Policy and Urbanization in the Dominican Republic and Costa Rica (Gainesville: University of Florida Center for Latin American Studies, 1972), p. 67. This is in general agreement with the data in Las Sociedades Actuales which found in E1 Salvador 67 percent of housing generally to be deficient but 77 percent of rural housing to be so; comparable figures for Costa Rica were 38 percent generally and 50 percent in rural areas.

3. Koth, Housing in Latin America, p. 100. Emphasis is from Koth.

4. See the section on FUNDASAL in Chapter VII.

5. BID estimates that in most Latin American nations at least ten percent of the GDP would have to be devoted to public housing on an ongoing basis to eliminate current deficits and maintain minimum standards.

6. San Salvador levies are further subdivided into permanent, eventual and local but these classifications need not concern us here.

7. It is sometimes difficult to tell the players without a scorecard. One national legislator, a former San José city councillor, tells of seeing other ex-councillors lobbying in the Assembly against municipal tax increases for San José. These same individuals had voted for similar tax increases when on the municipal council, and had proclaimed loudly the need for additional revenue.

8. One informant, for example, owned two supermarkets. One was 10cated in San José, the other in the suburban community of Escazu. During the period (about seven years) he had owned them, Escazu had been granted two tax increases that affected him; San Jose had been turned down by the Legislature three times. At the time of our last conversation in early 1974, his Escazu supermarket, which was one-third the size of the San Jose supermarket with one-quarter the volume of business, paid six times as much in municipal taxes and fees.

9. And when adopted, it was based on and nearly identical to an earlier schedule dating back to 1933 .

10. Much of the material in this section is based on Ebel, "The 
Decision-Making Process" and on interviews with Dr. Fidel Chávez Mena, Dr. Victor Manuel Cuéllar Ortiz, Manager of Asociación Salvadoreńa de Industriales and Don Daniel Escobar, San Salvador Municipal Secretary.

11. PDC is publicly committed to improvement of community morals. It is also publicly committed to shifting tax incidence away from small businessmen. Most bar owners, etc., are small businessmen. My own impression is that this was an attempt to maximize tax revenue from this source, realizing that demand for commercial vice is very price inelastic. PDC could thus appear not to be taxing small businessmen while San Salvador could enjoy increased tax revenues.

12. Ebel, "The Decision-Making Process," p. 212.

13. As late as April, 1974, I was informed by an official of ASI that the San Salvador business community favored municipal tax reform. It had opposed the 1964 measure not because it opposed higher taxes per se but because it did not feel that sufficient rational modification of the entire structure was involved.

14. There are many in E1 Salvador who maintain, loudly and openly, that Duarte did in fact outpoll Arturo Armando Molina of the PCN in the 1972 presidential election. A full-page advertisement in La Prensa Gráfica of 14 February 1974 refers to Duarte as: "The President elected by the People." In any event, he was implicated in the attempted golpe de estado of March, 1972, and is currently in exile in Venezuela.

15. And it is sometimes forthcoming. A Duarte-originated project for expanding and modernizing the municipal markets received widespread support. The bill providing national government guarantees for a BID loan to San Salvador for this purpose was not only approved by the Legislative Assembly but was cosponsored by ten legislators (of whom one was MNR and six were PCN) from seven departments.

16. I am indebted to William $J$. Allen and Fred D. Wood for this information.

17. Parking meters abound in downtown San Salvador but are universally ignored, and with good reason. They are unmodified U.S. models with instructions in English and designed to function with U.S. nickels and dimes.

18. It will be remembered that at this time the office of Municipal Executive was filled by the Governor of San José Province, appointed by the Central Government.

19. All events prior to 1955 have been constructed from the memories 
of those involved. There is no written record.

20. James E. Tribble to Hubert Federspie1, 5 January 1955.

21. Luis A. Truque G., Chief Municipal Engineer, to Julio Caballero A., Municipal Executive, 8 March 1955.

22. Costa Rica, Imprenta Nacional, La Gaceta, 21 March 1955, p. 776.

23. San José, Municipal Council, Minutes of Regular Session Number 74, 22 July 1955.

24. It is customary in policy analysis to term any request made of the political system a demand, no matter how conciliatorily it may be phrased.

25. La Gaceta, 12 October 1955, p. 2959.

26. Article 3 of award terms, Minutes of Regular Session Number 101, 29 February 1956.

27. La Gaceta, 5 July 1957, p. 1538.

28. Minutes of Extraordinary Session Number 28, 15 November 1957.

29. Councillor Vargas Castro, as reported in Minutes of Extraordinary Session Number 28.

30. Councillor Cortes Bolanos, as reported in Minutes of Extraordinary Session Number 28.

31. Costa Rica, Contraloría General de la República, Oficio Numero 868, 26 February 1958.

32. Minutes of Regular Session Number 175, 4 March 1958.

33. This was not the firm who submitted the lowest bid for the German parking meters, but another, Eduardo Maroto e Hijos.

34. Ordinance Number 4, Regular Session Number 51, 3 March 1959.

35. La Gaceta, 15 July 1959, p. 1527.

36. José Rafael Cordero Croceri to Luis Quesada, 28 October 1959.

37. Carlos Lara to Oscar Chacon Jinesta, 22 July 1960.

38. Chacon to Lara, 26 July 1960.

39. Minutes of Regular Session Number 262, 21 April 1961. 
40. Ordinance Number 3, Regular Session 262, 20 June 1961.

41. José Rafael Vega Rojas, Ad Hoc Secretary of the Legislative Assembly, to Joaquin Vargas Gene, Minister of Government, Police, Justice and Grace, 6 July 1961.

42. Minutes of Regular Session Number 295, 22 August 1961.

43. Minutes of Regular Session Number 301, 12 September 1961. This is not a direct translation but does contain the essence of the Council's statement.

44. M.A. Padillo J. to Rafael Paris Steffens, 14 July 1965.

45. Decree Number 2366, La Gaceta, 29 July 1965.

46. Decree Number 3580, La Gaceta, 17 November 1965.

47. La Gaceta, 12 January 1966, p. 114.

48. Municipality of San José, Licitación Publica No. 22-70, 26 October 1970 .

49. Minutes of Regular Session Number 87, 12 February 1971.

50. Decree Number 2047-G, La Gaceta, 16 November 1971.

51. San Jošé (Costa Rica) La Prensa Libre, 9 November 1971, p. 14.

52. San Jose (Costa Rica) La Nación, 9 November 1971, p. 6 .

53. La Nación, 10 November 1971, p. 6.

54. La Prensa Libre, 10 November, p. 13.

55. La Nación, 12 November 1971, p. 14 .

56. La Prensa Libre, 12 November $1971, \mathrm{p} .4$.

57. Some activities in Costa Rica commercial life move at a very leisurely pace. To cash a check or make a deposit in a bank routinely takes from one-half hour to a full hour. As executive time is too valuable to be spent in this fashion, a veritable army of low-paid messengers and collectors are hired to perform these and similar tasks. Generally these employees ride motor scooters which they park anywhere there is space. It is easy to see why they would find the new parking regulations onerous.

58. Minutes of Regular Session Number 213, 10 December 1971 .

59. Minutes of Regular Session Number 426, 24 May 1973. 
60. Ibid.

61. A comparison with the City of Portland is informative:

$$
\text { San José Portland }
$$

Parking meter revenues as \% of

$$
\text { city's current revenue }
$$

Number of employees

7.6

95

2.2

Cost of collection as \% of revenue from parking

Number of parking meters (approximately)

$\begin{array}{rr}43.1 & 17.7 \\ 2,000 & 7,000\end{array}$




\section{CHAPTER VII}

\section{RESULTS}

In this chapter the end results of public housing and municipal revenue policymaking are considered. In housing, INVU and IVU will be compared as to their current philosophy and practice in terms of client selection, financing arrangements, and in more concrete terms, of actual performance in providing housing. To furnish an added dimension, IVU and FUNDASAL will also be compared. The results of public finance policymaking are presented in terms of current budgets and patterns of municipal revenues and expenditures. San José and San Salvador will not only be compared one with the other, but will be examined against the backdrop of de Moraes' developmental paradigm.

\section{PUBLIC HOUSING}

\section{Instituto Nacional De Vivienda Y Urbanismo}

The ongoing policy output in the field of public housing in San José, and in all of Costa Rica, is to be found basically in the dayto-day activities of INVU. To be sure, INVU is not the only agency involved in public housing provision in Costa Rica, nor is public housing INVU's only task. Nonetheless, it is the lead agency in the field and housing is its primary concern. INVU lists as its first objective:

To provide families who lack adequate lodging the means necessary to acquire housing with their own resources. In this 
direction, INVU is to give preference to urban and rural families of low income. 1

In many of its housing practices, INVU resembles a private developer. Its first activity, at least in its major projects, is the acquisition of 1 and.

Usually this land is a coffee finca. Choice of finca is determined not only by availability--INVU has, but to date has not used, legal authority to expropriate and purchase land--but also by location in relation to existing or proposed employment opportunities. A good deal of cooperation exists with other autonomous agencies. Often, for example, ICE will not provide electricity nor SNAA sewers to certain industrial sites unless INVU plans or can provide nearby housing.

The land is then divided into large tracts, capable of holding from 500 to 2000 housing units. These tracts are developed one by one as funding becomes available and other agencies are prepared to provide urban services. INVU lays out and plans the development, specifying number, type and situation of houses. When conditions permit, when funding and infrastructure are available, INVU calls for bids. Construction contracts are awarded to the lowest bidders.

Most of the contracts are for completed single-family dwellings; presently about 75 percent of the units built are of this type. Ten to 15 percent of the units are classified as minimum housing--essentially shells with roof, floor, outside walls and an interior source of water and sewer hookup. The different types are not mixed in any one project.

Untii 1973, INVU provided urbanized lots in some projects. These were simply graded plots with water available. The idea was 
that the inhabitants-to-be of these projects would then aid one another in construction of their houses. In practice, however, the people involved tended to sell the construction materials, whether provided by INVU or belonging to their neighbors, and pocket the money. ' The spirit of mutual aid and community assistance so evident in the construction of squatter settlements seems to vanish when institutionalized. INVU no longer provides urbanized lots.

Perhaps the most usual measure of output in the field of housing policy is actual number of cases of housing assistance to family groups. Table XXIII shows what INVU accomplished in the six years immediately preceding this study.

TABLE XXIII

HOUSING ASSISTANCE PROVIDED BY INVU, 1967 TO 1972

$\begin{array}{lrrr}\text { Year } & \begin{array}{l}\text { Living Units } \\ \text { Constructed a }\end{array} & \text { Other Assistance b } & \text { Total } \\ 1967 & 1,268 & 241 & 1,527 \\ 1968 & 724 & 393 & 1,117 \\ 1969 & 149 & 484 & 633 \\ 1970 & 666 & 1,223 & 1,889 \\ 1971 & 1,267 & 1,016 & 2,283 \\ 1972 & 1,751 & 1,291 & 3,042 \\ & & & 10,491\end{array}$

(Note: a includes minimum housing; $b$ includes urbanized lots and the various financing arrangements, except credit extended to buy INVUconstructed housing.)

SOURCE: INVU, Memoria 1972.

Although INVU is a national agency, its housing contruction practices make it appear basically an urban housing agency. Of the 5,843 living units constructed, 5,481 or 94 percent were built in urban areas. 
Other assistance was less concentrated; some 57 percent of the activity in this category took place in urban areas.

Financing is another day-to-day activity reflecting housing policy. On the one hand, INVU must obtain overall funding for its projects and their operation; on the other hand it must consider financing arrangements for its clients.

INVU receives funding from a variety of sources. When it was established in 1954 it took over some $\$ 11,000,000$ from its predecessor, the housing office of the Social Security Administration. By law it received $\$ 600,000$ at the same time from the Central Government and a guaranteed annual appropriation of $\$ 1,200,000.2$ In addition, the National Insurance Institute and the Social Security Administration are permitted but not required to invest an unspecified part of their reserves in INVU. Moreover, INVU has a continuing income as those to whom it has loaned money or sold houses on credit repay their obligations. Finally, INVU can borrow both internally and externally. This is a very uncertain source of funds but the amounts, when available, can be considerable. The primary source of external funding is the Banco Interamericano de Desarollo (BID).

INVU has a variety of programs for funding its various client groups. Two of these, for rural households, will be mentioned only briefly. Four others, applicable in urban areas, are considered in more detail.

The two specifically rural credit arrangements are known as supervised rural credit and the rural communities program. Supervised rural credit is available to the small farmer who wishes to 
build or improve a home on his or her own 1and. The credit is supervised in that the money is accompanied by technical assistance or advice, and the borrower is presumably to pay some attention to this advice as a condition of obtaining the loan. Amounts ranging from $\$ 150$ to $\$ 2,000$ are available to each borrower with an annual interest rate of eight percent and a repayment schedule of between five and ten years, depending on the amount borrowed and household income.

In the rural communities program, families are given building lots in the vicinity of existing rural population centers. These lots are generally pieces of either abandoned fincas or unused portions of large plantations owned by multinational corporations. In addition to the lots, families are given enough credit to purchase $b_{i}$ 'ing materials for a home. Amount of credit and repayment terms a, ilored to the size of house needed and family income. It is assmm... that the family will do the actual construction. This program appears to be working more successfully than the parallel mutual aid or selfhelp programs in urban areas.

INVU operates two financing programs that are applicable in urban or rural areas. To date, both have been used more extensively in urban areas. The first of these is the savings and credit program. Under this program INVU establishes a regular savings plan for an individual. When the individual has saved a certain amount, he or she is eligible to be granted enough credit to purchase a house in an INVU project. The actual amounts of money involved, again, are tailored to the individual family's needs and resources. INVU also operates a savings and loan program for individuals 
needing money for a particular housing situation that does not involve a dwelling unit in an INVU project. INVU lists four uses to which the funds may be put:

1. Purchase of a dwelling unit and its lot, or construction of same on the borrower's own lot.

2. Purchase, expansion or repair of a dwelling unit.

3. Cancellation of a lien on the borrower's house.

4. Purchase of land [on which the house sits] by the owner of a dwelling when this [dwelling] has been built on someone else's property. 4

Under the savings and loan program, a borrower determines how much he or she needs and how long it will take him to save, usually, 25 percent of this amount. When he has saved his quota, INVU lends him the remainder at nine percent interest. A typical schedule, known as Plan 6 - 9, is shown below in Table XXIV. Plans range from $2-4$ to 10 - 12. The first number indicates the number of years over which the individual saves his share, in regular monthly amounts. The second figure indicates how many years he has to repay the loan received from INVU. Under Plan $6-9$ then, the individual saves in six years 25 percent of the amount subscribed and borrows the remaining 75 percent, to be repaid in nine years.

The remaining two forms of funding are the particularly urban ones of cooperatives and semi-urban credit. As used here, cooperative refers to the practice of an employer formally cooperating with INVU to expedite housing credit for his employees. Among the more usual forms of cooperation are an employer's agreeing to guarantee loans made his employees by INVU and the employer's agreeing to lend the employee the amount the employee would normally have to save. Under 
Plan 6 - 9 for example, an employer would lend the employee (or, more precisely, pay INVU on the employee's behalf) an amount equal to 25 percent of the tota1 subscription. The employee could thus immediately use the money for housing purposes and not have to save for six years first. The employee would, of course, have to make loan repayments for 15 years rather than for nine.

\section{TABLE XXIV}

TYPICAL PAYMENT SCHEDULE, INVU SAVINGS AND LOAN PROGRAM

\begin{tabular}{rrrrr}
$\begin{array}{l}\text { Amount } \\
\text { subscribed }\end{array}$ & $\begin{array}{l}\text { Amount } \\
\text { to save }\end{array}$ & $\begin{array}{l}\text { Amount } \\
\text { of loan }\end{array}$ & $\begin{array}{l}\text { Monthly } \\
\text { saving } \\
\text { payment }\end{array}$ & \multicolumn{1}{l}{$\begin{array}{l}\text { Monthly } \\
\text { loan } \\
\text { payment }\end{array}$} \\
$\$ \quad 5,000$ & $\$ 1,250$ & $\$ 3,750$ & $\$ 21.60$ & $\$$ \\
10,000 & 2,500 & 7,500 & 43.10 & \\
20,000 & 5,000 & 15,000 & 86.20 & 101.60 \\
30,000 & 7,500 & 22,500 & 129.20 & 303.20 \\
40,000 & 10,000 & 30,000 & 172.30 & 406.30 \\
50,000 & 12,500 & 37,500 & 215.40 & 507.90 \\
60,000 & 15,000 & 45,000 & 258.40 & 609.60 \\
70,000 & 17,500 & 52,500 & 301.40 & 711.20 \\
80,000 & 20,000 & 60,000 & 344.50 & 812.80 \\
90,000 & 22,500 & 67,500 & 387.50 & 914.40 \\
100,000 & 25,000 & 75,000 & 430.60 & $1,016.00$
\end{tabular}

SOURCE: INVU, Sistema de Ahorro y Prestamo.

Finally, the semi-urban program extends credit and technical assistance to families with possession of individual parcels of land on the urban fringes of populated areas. If the families do not have clear possession, credit may be extended to buy the land, as well as pay for construction materials. It is expected that the families to whom credit is extended will provide most of the labor for the construction of their individual homes.

Although it is nowhere made explicit, the creation of semi-urban 
credit is a tacit recognition of squatter's rights. (Semi-urban credit is INVU's newest program; it began in 1973.) Rather than engage in massive programs to relocate squatters or simply use the force of the law to drive them fr?m affected property, INVU has decided to make the best of it and regularize squatting. On the one hand, this involves making money available to buy the land from its legal owner, or at least to obtain a long-term lease. On the other hand, it involves giving the squatter a chance to replace his tugurio shack with a sounder and more sanitary dwelling. Throughout Central America squatter settlements are no longer regarded as a blight to be forthwith eliminated but as part of the national housing stock to be upgraded, legitimized and used.

Two additional observations may be made on INVU's funding practices; the delinquency rates of their clients and some indication of the size of INVU's operation. At the end of 1972, some three quarters of INVU's debtor-clients were making their payments on schedule. About seven percent were seriously overdue, six months or more behind 5 schedule. There is no evidence that INVU has any mechanism other than moral suasion to pressure their deadbeat clientele into paying. Nor is there any evidence that INVU would be inclined to do so.

INVU is in a difficult situation in this regard. From one side its main external source of funding, BID, presses it for prompt collection as a condition for any possible future loans. From the other side, internal Costa Rican political pressures effectively preclude any firm action against delinquents. All of these considerations may be reflected in the figures showing the rate of nonpayment to be 
slowly increasing in recent years.

Because so much of INVU's funding varies so widely from year to year, detailed figures on the operation do not provide enough useful information to justify their compilation. However, Figure 13 may give some idea of the size of INVU from a financial viewpoint.

Capital investment in housing

$\$ 57,000,000$ Loans made by INVU $24,000,000$ Reserve fund 1972 income from own sources Debts owed by INVU $17,000,000$ $9,500,000$ $11,200,000$

Figure 13. Selected financial data for INVU, 31 December 1972. It should be noted that about 60 percent of INVU's debt is owed to agencies outside Costa Rica, primarily to BID.

The third general aspect of INVU activity to be considered here is client selection, both in terms of class and in terms of individuals. The major construction activities are designed to benefit primarily the middle and lower middle classes. The urbanized lot and minimum housing programs were aimed at the very poor, but urbanized lots are no longer provided. Minimum housing accounted, in 1972, for just under 12 percent of INVU's 'housing solutions' (less than nine percent by value). The rural communities program, the only one the poorest of the rural dwellers can take advantage of, benefited in the same year a total of eight families. Semi-urban credit, of possible benefit to the lowest income classes was just being introduced. At the time the field work for this study was completed, then, the poorest class had, at best, access to only one-eighth of INVU's activity; the other seven-eighths could be used only by the middle or lower 7 middle class. 
Some of INVU's programs are open to anyone who can meet stated criteria; others require a very strict selection from among many applicants. The savings and loan program, for example, welcomes and will contract with anyone willing and able to meet its requirements. Most programs, however, nust be selective. There are far more applicants than opportunities for available housing units or funds. In cases where INVU is working in cooperation with another agency, that agency may select the clients. This would be the case where, for example, the National Petroleum Company (RECOPE) and INVU together provided 2,900 housing units for RECOPE's employees near its refinery in Limón.

For those cases where specific applicants must be chosen, and where INVU must make the choice, as in the occupants for the INVUconstructed housing projects, a variety of criteria is taken into account. First, INVU considers the three big questions about each applicant: how needy each is, how long each has been on the waiting list and, of paramount importance, how able each is to make the payments on time. INVU scores each applicant on each characteristic, combines the scores, and ranks the results.

To further distinguish among applicants, INVY conducts, both overtly and covertly, a socioeconomic study of each applicant family. In the course of this INVU seeks information on conjugal harmony or discord, excessive drinking or gambling, and general neighborhood reputation. With these data, the rankings are refined once again and an ordered 1ist of the most eligible applicants is drawn up. From this list applicants are chosen in order whenever an opening or opportunity 
appears. New applicants are fitted into the list according to their ranking. All in a11, it is a reasonably sophisticated if overly rigorous system for choosing individual families to be served.

The final point to be made about INVU in this section is a reiteration of the first. Although INVU is not the only agency involved in providing, or at least funding, public housing, it is the lead agency. In the period 1968 through 1972, it provided 48 percent of Costa Rica's public housing. In addition to furnishing more housing than any other agency, INVU a1so is the broadest based. The other agencies involved in public housing either supply housing only for their own employees or limit their activities to low-cost loans.

One aspect of INVU's activities not considered here is an estimate of how successful it is in reducing Costa Rica's housing deficit. This will be provided below in the section comparing INVU's programs and performance with those of IVU and FUNDASAL.

Instituto de Vivienda Urbana

IVU, as the name indicates, is primarily a housing agency. Unlike INVU, it does not have responsibility for national urban planning or similar functions. As its name further indicates, IVU is particularly an urban housing agency. Rural housing, also within INVU's purview in Costa Rica, is provided in El Salvador not by IVU but by a separate agency, the Instituto de Colonización Rural (ICR) .

Like its counterpart in Costa Rica, IVU's first concern is obtaining land. Unlike San José, San Salvador has no handy fincas that can be purchased or expropriated adjacent to major urbanized areas. IVU, therefore, has not been able to be as selective as INVU in choice 
of building sites; it has had to acquire a greater number of smaller scattered locales.

IVU provides housing through three basic sets of practices: auto-construction, direct contracting, and administration. Autoconstruction is similar to the urbanized lot program tried and abandoned in Costa Rica. In auto-construction, IVU provides the lots and building materials and the tenants-to-be provide the labor. IVU monitors closely the activities in auto-construction and schedules people-so much time for general labor, so much for work on what will be their own dwelling, so much time for rest. Even so, there have been cases of buildings left half completed. Worker energy has a tendency to vanish once a roof, floor and outside walls have been finished. IVU has used auto-construction for both single-family and multiple-family dwelling units.

Direct contracting needs little elaboration. IVU draws up plans and specifications for a particular project and invites bids on it. All things being equal, the lowest bidder is awarded the contract and builds the project. IVU has from time to time, however, attached particular conditions to the bids. One of these requires a guarantee from the chosen contractor to employ and train a certain number of those who will live in the completed project. Since almost none of the IVU housing is destined for the poor and unskilled, this practice is neither as widespread nor as useful as it might be.

Another innovation introduced by IVU was the experimental housing program. In this program ten companies were given general specifications for particular types of housing--e.g., 50 square meters of 
floor space, two bedrooms, bathroom, kitchen, living room--and were told to build a unit or two of each type as cheaply as possible, using whatever building material they wished. IVU suggested, however, that general preference be given to materials of domestic manufacture and specific preference to materials worked on in its own laboratory. If any company was able to design and build a housing unit at much less cost than its competitors, and below current housing prices, it would receive a sizable contract from INVU. Unfortunately, final data on the experimental housing program are not yet available so it is not known if any great cost breakthroughs were made.

In construction by administration, IVU itself does the work. It is restricted to construction in tugurio areas and the actual labor is performed by the inhabitants of these areas. Construction by administration differs from auto-construction in three important respects. First, the workers in construction by administration are hired by IVU and paid wages. Generally, they will move into the housing thus built, but this is not a given. Second, the end result of this activity is seen as either urbanized lots or minimum housing; autoconstruction aims at a more finished product. Third, construction by administration is used on occasion for non-housing construction such as communal latrines to serve tugurios.

Again, the single most useful measure of policy output in the field of public housing is actual number of housing solutions, including urbanized lots, provided. Table XXV shows IVU's accomplishments from 1967 through 1972. Accurate data were not available for number of urbanized lots provided. However, it was estimated that about one 
and one-half times as many lots as houses were supplied. If this figure is accurate, some 8,000 lots were prepared and housing soiutions in all totalled between 13,000 and 14,000 units.

TABLE XXV

HOUSING ASSISTANCE PROVIDED BY IVU, 1967 THROUGH 1972

Year

1957

1968

1969

1970

1971

1972

Total
Number of Housing Units

880

1,415

1,380

1,050

200

484

5,409

SOURCE: IVU, Memoria de Actividades 1973.

IVU provides basically three types of housing. One, minimum housing, has already been described. The others are completed singlefamily and multiple-family units. Single-family housing contains on a single fioor, two bedrooms (rarely three), a kitchen, a bathroom and a living room. Multiple-family units are the same except they are a bit larger and contain three bedrooms. At first glance it might seem unusual for apartments to be larger than single-family houses but greater population densities on scarce land can be obtained with this mix than with larger, one-story, single-family houses. Strict regulations govern the maximum cost for each type of housing. Table XXVI shows how these limits increased over a ten-year period. Actual average unit cost of single-family housing completed in 1972 was $\$ 2,545$ and of multiple-family housing was $\$ 2,908$. 
TABLE XXVI

MAXIMUM ALLOWABLE PER UNIT COSTS FOR IVU HOUSING, IN \$C.A.

1964

Minimum housing

Single-family housing

Multiple-family housing

480

1,480

2,080
1969

1974

SOURCE: Information supplied by IVU Architect Oscar Arrivillaga.

IVU receives its funding from the same general sources as INVU:

its own resources including rent and mortgage payments; subsidies from the Central Government; internal borrowing through bonds and loans from financial institutions; and foreign loans, particularly from USAID and BID. IVU has never been as well capitalized as INVU. Instead of taking over public housing from an agency with $\$ 11,000,000$ as INVU did, IVU replaced Mejoramiento Social, a destitute agency that had managed to construct only 1,000 housing units in its eight years of existence. Moreover, IVU has no guaranteed subsidy from the Central Government. The agency asked that it receive automatically three percent of the annual National Government budget; this suggestion was flatly rejected. In fact, IVU is one of the first to suffer cutbacks whenever the Government faces a financial exigency.

IVU maintains three sorts of financial arrangements for its 12 clients. Urbanized lots are sold on the installment plan. Actual monthly payments are tailored to individual income but in no case is the repayment period to be longer than ten years. The usual interest charges is six percent.

Single-family housing is financed on a contract or rent-to-own basis. Unlike payments for urbanized lots, payments for housing are 
not tailored to family income. Terms are reckoned on a 20-year payment schedule, at six percent interest. Monthly payments for housing in a specific project are calculated and made known in advance. Families unable to meet these payments are expected to refrain from applying for housing they cannot afford.

IVU's third financial program for its clients is a straight rental operation. Again, monthly payments are fixed, and not based on family income. Rents are pegged so that a particular rental project, and borrowing and other administrative costs attached to it, are paid off in 20 years. Rents collected after the apartments have been paid go into IVU's reserve fund. IVU reserves the right to raise rents at any time to keep up with inflation. Tenants not willing or able to pay the increase are expected to seek less expensive housing.

A total picture of IVU's financial position would be difficult to compile. In addition, it varies considerably from year to year given the vagaries of both Central Government support and external funding. Nonetheless Figure 14 gives an indication of the size of IVU's operation from a financial viewpoint.

Investment in housing being sold by contract $\$ 24,000,000$ Investment in rental housing $6,400,000$ Debts owed by IVU Income from own sources, July 1972 - June 1973 $12,400,000$ $3,000,000$ Reserves and unexpended capital 26,800,000

Figure 14. Selected financial data for IVU, 30 June 1973.

About 84 percent of IVU's debt is owed to external lenders, again, principally USAID and BID.

Although IVU does not operate any savings or loan programs as INVU does, there are two government programs to assist individuals in 
financing their homes. These deserve brief mention here. One is the Financiera Nacional de Vivienda (FNV); the other is the Fondo Social para la Vivienda (FSV).

FNV was created in 1963. It is described as a "public corporation of undefined function, with autonomy in the administration of its patrimony, intended to serve as a Central Credit Bank for housing." Essentially, FNV has four functions: serving as a credit reservoir for the savings and loan associations that have come into being since its establishment; insuring individual savings accounts up to $\$ 12,000$; insuring the associations' home mortgages; and creating a secondary market for these mortgages.

The original capital for FNV came from a Central Government subsidy of $\$ 800,000$ and a USAID loan of $\$ 3,100,000$. Prior to the establishment of FNV, savings and loan associations were unknown in El Salvador. Three have since been formed. These associations pay their depositors six percent on savings while the commercial banks pay four percent. The two percent spread is a matter of custom and not, as in the United States, mandated by law.

Mortgage loans backed by FNV may be made for new homes, up to So percent of the value of the home, but no loan can be for more than $\$ 25,000$. Maximum term for the 1oans, which bear interest at nine percent, is 20 years. Oscar Salegio, Chief of TVU's Engineering Department, estimates about one-quarter of all new housing built by the private sector is financed by FNV-backed mortgages.

The other housing finance agency in EI Salvador is FSV which has adopted as its motto: "Building for the worker." It is a new program, 
dating only from 1973. Designed to build housing for individuals who are regularly employed but still unable to meet payments in IVU projects, FSV is funded by contractors, workers, and employers. Workers, who save their money with FSV, will be able to borrow from it to finance minimum housing. Contractors, who Iend money to FSV, expect to profit both through being awarded construction contracts and through interest paid them. Employers, who also lend money to FSV, expect to get in return not only interest but a healthy and adequately housed, if almost captive, workforce.

FSV has not been in operation long enough to assess its performance. In a full-page advertisement in La Prensa Gráfica it described itself as "constitutional mandace converted into reality." 16 The advertisement continued:

The valiant contribution of the State, of the patron and of the worker will make it possible to realize massive construction of housing. In granting credit, preference will be given to workers with the lowest incomes, as established in accordance with appropriate regulations. For this the SOCIAL FUND FOR HOUSING has been created. New urban solutions, innumerable sources of labor and major economic growth. Sufficient reasons to get on with progress.17

FSV represents a radical departure from earlier policies of no direct government credit assistance to individuals. It remains to be seen how successful it is.

A final consideration in the examination of IVU's financial practice is the timeliness of its clients' repayments. INVU published detailed figures on how many of its clients were up to date in their payments, how many were behind, and how far behind. IVU provides no such data. It does, however, give some indication as to actions taken against delinquent debtors. In the courts of El Salvador in 1972- 
1973, IVU initiated the following proceedings for "reasons of delinquency and other causes": 300 demands for dismissal of tenants; 177 warnings of eviction; and 103 petitions for eviction. Twenty-four properties were repossessed as a result of complaints filed in earlier 18 years.

It would be assumed that in the less open Salvadorean system, IVU would be free to administer the financial side of its program without the political pressures with which INVU must contend. This is not necessarily true. In 1968, under the external influence of BID, IVU tightened up its collection procedures and announced that all clients who failed to pay what they owned in 15 days would be evicted. A great hue and cry arose. PDC siezed the opportunity to denounce the government for heartless treatment of the very social group it had promised to serve. IVU was not prepared for this response: "Shocked by the unexpected outbursts, the agency [IVU] directors withdrew their 19 demands for immediate mortgage payments." Neither country, neither agency, then, has a monopoly on fiscally remiss but politically potent clients.

It is worth emphasizing once again the nature of IVU's clientele. IVU does not even pretend to provide housing for the lowest income segment of society, those with a family income of less than $\$ 250$ per month. Salegio estimates that 30 percent of the urban families in El Salvador cannot afford minimum housing of 40 square meters, to be 20

paid for in 20 years at six percent interest. IVU's housing, then, is available to those making at least $\$ 250$ per month but not making enough to compete successfully in the private housing market. 
Like INVU, IVU makes a socioeconomic study of each applicant. Unlike INVU, there is no ranking of the applicants on the basis of purely family characteristics. IVU's aim in selecting clients is to choose those who are the best overall fit for the particular housing to be filled. If there are many applicants who do not fit a project for some non-economic reason (e.g., family size), future IVU projects may be designed with this applicant group in mind. Once a particular project is designed, however, clients are selected to fit; the project is not modified to suit the needs or demands of potential clients. One activity IVU engages in that INVU does not is the contruction of housing for particular occupational groups. IVU will often announce that a particular project is being built, for example, to house nurses, teachers and clerks. ${ }^{22}$ There can be a variety of motives for this. One may be that these groups are regarded as making special contributions to the country's development. Another may be that the amount and stability of their incomes places them in an economic category IVU finds desirable or convenient to serve. Yet a third reason may be that many of these people are government employees and subsidized housing can be offered them in lieu of better wages. Whatever the underlying principle, this practice removes large portions of IVU-supplied housing from the reach of the general populace.

Fundación Salvadoreña De Desarollo Y Vivienda Minima

In establishing minimum income criteria, then, IVU has effectively eliminated a large portion of the housing-short population from participation in its program. The only quasi public agency designed 
to serve the lowest income classes is FUNDASAL.

FUNDASAL, a private non-profit corporation, was established in

1972 to attack the entire problem of marginality. What constitutes

marginality is vividly described:

It signifies a lack of food and housing, school and work, health and recreation. The marginal [person] is one without bread and without a roof, illiterate and unemployed, beaten down and sick. Marginality signifies existence on the margin of the most precious values of our society. The lack of an adequate house degrades the family with a promiscuity and a greed that is almost animal. Hunger and idleness destroy the bodies and the wills: the child--almost a man--begs through the public streets; the girl of thirteen--now a woman--sells her body in the bars and bordellos; the youth--now an adult-compensates for his impotence with a senseless machismo; the man--now aged--drowns his frustration in a bottle of guaro. In the creed of marginality, good is anything that helps survival: prostitution is an office; robbery, a career; alcohol, a refuge. God, country, family and honor mean nothing to one who has no father, no land, no home, no life of his own. 23

FUNDASAL regards the provision of housing as the single most critical activity in its attack on marginality.

A11 FUNDASAL housing is provided through a form of modified auto-construction. Professional builders and tradesmen hired by FUNDASAL work through the week on the housing projects. On Sundays the future tenants, under supervision, provide the necessary unskilled labor. All housing is in the form of rent-to-own or contract sale units.

As usual, it is difficult to assess the performance of an organization this new. The usual measure, housing units provided, does give some indication although no comparisons over time are possible. At the end of 1973, FUNDASAL was in the process of constructing 2,270 24

units. The first 525 of these, in San José del Pino, were completed and occupied by the tenants in April, 1974. 
FUNDASAL seeks its funding wherever it is to be found. It receives some subsidy from the Central Government, $\$ 80,000$ in 1973 , but the Government has made no long-term commitments. Total income in 1973 was $\$ 988,800$. In addition to the subsidy there were miscellaneous donations of $\$ 68,800$ and loans of $\$ 340,000$. The largest single grant to date was $\$ 640,000$ in 1974 from the Interamerican Foundation. 26 Municipalities often donate the land for the housing projects. Domestically, FUNDASAL has borrowed money from the Central Reserve Bank and the private Mortgage Bank of El Salvador. Externally, it has received major grants and loans from the Panamerican Development Foundation, USAID, Campaign Against Hunger and New Homeland plus smaller amounts of assistance from a wide variety of sources. Private individuals and coporations both within and without El Salvador con27 tribute money and materials.

FUNDASAL's financial arrangements with its clients are quite simple. The price of each housing unit to the tenant is somewhere between $\phi 1,500$ and $\$ 2,500$ depending on the size of the unit and the terms under which FUNDASAL was abie to obtain funaing for the construction. The wealthier tenants pay off their debt at 15 colones per month, the poorer tenants at ten colones per month.

Client selection criteria for FUNDASAL housing are also quite simple. The basic requirement is that family income not exceed $\$ 250$ per month. By its own estimate, this income limit is high enough to create for FUNDASAL a pool of potential clients that includes more than 60 percent of housing-short urban Salvadoreans. Within this range; need is taken into account. Tenants are expected to have lived 
at least five years in the area; FUNDASAL does not wish to do anything that might encourage migration to the capital. Established families are preferred as tenants. To be regarded as established, family members should have lived together for two years; a longer time period is better. Finally, FUNDASAL wants tenants who are disposed to work Sundays in auto-construction. Its feeling is that families willing to make this commitment are not only particularly deserving but also are less likely to let their house deteriorate. FUNDASAL does indicate, however, that none of their criteria is written in stone; rather they are to be regarded as flexible guidelines.

Two other facets of FUNDASAL's operation are discussed here: one, its institutional relationship with other agencies, and two, the non-housing aspects of its program to fight marginality.

Like other builders of housing, FUNDASAL requires a package of permits, approvals and urban services. Seeking these brings it into contact, and sometimes into conflict, with a number of other agencies. The nature and low budget of its operation effectively banish FUNDASAL housing to the more remote outskirts of the urban areas. This makes the obtaining of many urban services more difficult. Difficulties are compounded in dealing with government agencies that are both regulatory and service providing.

One such agency is ANDA. FUNDASAL housing, like other housing, requires the Vo.Bo. of ANDA before it can be legally built. However, obtaining the Vo.Bo. of ANDA qua regulatory agency in no way guarantees the provision of sewers and water from ANDA qua service agency. Much the same difficulty exists with DUA. DUA must approve con- 
struction plans but such approval does not mean that DUA will provide the site with adequate road access. Preconstruction approval must be obtained not oniy from these agencies of the Central Government but al so from the municipality. Generally municipalities, especially San Salvador, give their Vo.Bo. almost automatically; CAESS, the electric company, will provide service anywhere, anytime, to anyone willing to pay for it.

In some cases ANDA and/or DUA will refuse FUNDASAL permission to build. FUNDASAL's reaction is usually the same as that of other Salvadoreans, it goes ahead and builds anyhow, illegally. It should be noted that there are on the outskirts of San Salvador a great many illegal dwellings that are not marginal. These are sound, healthy, often large and expensive houses that are illegal solely because they lack the Vo.Bo. of ANDA or DUA. Many of these illegal dwellings have no road access and can be reached only on foot by long flights of stairs. ANDA has been known to relent and provide services to FUNDASAL housing, after refusing it permission to build. ANDA does not seem to let its regulatory and service functions interfere with one another.

One of FUNDASAL's strongest institutional links is with José Simeon Cañas University of Central America. To a 1arge extent, the University acts as FUNDASAL's research arm and provides it with a great deal of technical assistance. At the same time, FUNDASAL's projects serve as laboratory and training ground for the University's engineering, planning, and community development students. FUNDASAL has adopted the position that provision of housing 
alone is not a sufficient attack on marginality. To complement the housing program, it undertakes educational, economic, and community development activities.

Educational activities are pragmatic and aimed at adults. The prime targets are FUNDASAL's current or projected tenants but there are no restrictions. A typical program was undertaken in conjunction with the movement of families into San José del Pino. (See above, p. 274.) Courses were given in the day-to-day concerns of mother-child relationships, human reproduction, venereal disease, social development, sanitation and parasite control. The courses were intended primarily for the new tenants in FUNDASAL housing but others from the tugurios were welcome to, and did, attend.

Economic activities are designed to maximize the productive capacity of the marginal population. In one case FUNDASAL established a small ormamental iron workers' cooperative and located a market for the lamps, watch faces and mirror frames it produced. In another situation it organized a building materials cooperative to produce concrete pipes, sewer lines and similar fixtures. FUNDASAL also set up two cooperatives to make and market Persian-types rugs and carpets. Finally, in an effort to mobilize what little savings are possible in the tugurio and to Iiberate its tenants from usury, FUNDASAL has established small credit unions, using some of its patrimony as seed capital,

Although it budgets less than five percent of its expenditures for community development, FUNDASAL regards organization as a vital sector in its war on marginality. FUNDASAL considers itself a non- 
political entity that politicizes its clients. It is estimated that among the marginal population of San Salvador, ten percent are on the right wing, ten percent on the left wing and the remaining 80 percent are totally apolitical. FUNDASAL attempts to break this shell of political apathy by organizing its tenants. It has had some success. Tenant organizations have become pressure groups and successfully lobbied for roads and bus service.

This organizing activity has also had a partisan political effect that FUNDASAL officially maintains is unintended. Before organization in particular tugurio areas, few of the people voted and of these few votes, 90 percent were cast for PCN. After organization, the number of voters increased fivefold and PCN received only ten per30 cent of the votes.

Two factors complicate community organization in the tugurios of of San Salvador: Mano Blanco and Organización Democrática Nacional (ORDEN). While neither group can be linked directly to the Central Government, both do share the same Hobbesian view of mankind and governance as PCN. Mano Blanco is dedicated to maintaining order among tugurio dwellers. Protest marches demanding jobs or improved bus service upset its sense of harmony; Mano Blanco does its best to discourage these practices at the same time FUNDASAL is encouraging them.

ORDEN is a right-wing para-military organization whose purpose is the repression of any manifestations of liberalism. A weekly newsmagazine referred to it as "the dreaded 50,000 member Orden [sic] militia." ${ }^{31}$ ORDEN has recently been implicated in the murders of two Jesuits and others with similar leftist leanings. Both of these 
groups have opposed FUNDASAL's community organizing efforts in the tugurios. Where their initial opposition has been unsuccessful and FUNDASAL has organized the inhabitants, support for both Mano Blanco and ORDEN has dwindled seriously.

FUNDASAL, then, attacks the whole area of marginality through community development, economic programs and provision of low-cost housing. It is considered here primarily because of the quasi-public nature of this last activity. In the section below, INV, IVU and FUNDASAL are compared on a variety of criteria.

Summary

In Chapter VIII some general conclusions about and comparisons of Salvadorean and Costa Rican housing in the larger sense are made. Here the day-to-day activities and programs are summarized. This section will also give some indication as to how successful the public housing programs are in reducing the public housing deficit in the two countries.

Some comparisons among the three agencies and their housing practices have been made above; Figure 15 gives a summary of the sa1ient characteristics.

One measure used in evaluating the success of public housing agencies is how much of the housing problem they solve. To determine this, it is necessary to know not only the supply side of the picture but also the demand, the size of the housing shortfall. A wide variety of estimates of the housing deficit is available for both Costa Rica and El Salvador. Most of these estimates are quite precise; some of them may even be accurate. Because these estimates do vary so 


\begin{tabular}{|c|c|c|c|}
\hline Characteristics & INVU & IVU & FUNDASAL \\
\hline $\begin{array}{l}\text { Average number of housing } \\
\text { solutions provided an- } \\
\text { nually, 1967-1972 (ex- } \\
\text { cluding urbanized lots) }\end{array}$ & 1,561 & 902 & N.A. \\
\hline $\begin{array}{l}\text { Provision of completed } \\
\text { standard housing }\end{array}$ & Yes & Yes & No \\
\hline $\begin{array}{l}\text { Provision of minimum } \\
\text { housing }\end{array}$ & Yes & Yes & Yes \\
\hline $\begin{array}{l}\text { Auto-construction, seif- } \\
\text { help, mutual aid }\end{array}$ & No & Yes & Yes \\
\hline Rental housing & No & Yes & No \\
\hline $\begin{array}{l}\text { Physical work performed } \\
\text { by the agency itself }\end{array}$ & No & Yes & Yes \\
\hline $\begin{array}{l}\text { Guaranteed subsidy from } \\
\text { the Central Government }\end{array}$ & Yes & No & No \\
\hline $\begin{array}{l}\text { Bonds sold to other } \\
\text { govermment agencies }\end{array}$ & Yes & Yes & N.A. \\
\hline Savings and loan program & Yes & No & Yes \\
\hline $\begin{array}{l}\text { Rigorous debt collection } \\
\text { procedures }\end{array}$ & No & Yes & No \\
\hline Socioeconomic class served & $\begin{array}{l}\text { Low to } \\
\text { Middle }\end{array}$ & $\begin{array}{l}\text { Lower } \\
\text { Middle to } \\
\text { Middle }\end{array}$ & Lowest \\
\hline $\begin{array}{l}\text { Housing for particular } \\
\text { occupational groups }\end{array}$ & No & Yes & No \\
\hline $\begin{array}{l}\text { Assistance to rural } \\
\text { families }\end{array}$ & Yes & No & No \\
\hline $\begin{array}{l}\text { Community organization } \\
\text { program }\end{array}$ & No & No & Yes \\
\hline $\begin{array}{l}\text { Level of cooperation/ } \\
\text { coordination with } \\
\text { municipalities }\end{array}$ & Low & Variable & High \\
\hline
\end{tabular}


widely, it is not realistic to accept any one of them as truly repre32

sentative. Even government figures are suspect. White, for example, states that the Salvadorean authorities give the housing problem "spuriously exact statistical treatment."

In an attempt to reduce the inherent biases and inaccuracies in this area and provide the maximum validity to our comparisons, we adopt here the estimates and projections made by outside agencies who have assembled data for both countries. To further confuse the issue and complicate measurements and comparisons, two different kinds of data are estimated: total deficit, and housing to be constructed annually by the public sector to meet a certain goal. These may or may not be presented in conjunction, and goals may or may not be set rationally, with a specific, realizable aim.

One set of estimates is provided by Jorge Riba to the Organiza34

tion of Central American States. His figures as to number of houses necessary to maintain the status quo are combined with actual performance figures for INVU and IVU in Table XXVII.

Riba's estimates of needed housing include that necessary to handle population increases and to maintain the current housing stock; he does not include any housing destined to reduce existing deficits.

Considering the future, Riba projects that in 1975 Costa Rica will have to build 18,700 units and El Salvador, 17,400 units. Comparable figures for 1980 are 21,600 and 19,600 respectively. Another source estimates 1975 housing needs at 19,400 units for Costa Rica and 36,000 units for E1 Salvador. 
TABLE XXVII

COMPARISON OF HOUSING NEED AND PUBLIC SUPPLY

COSTA RICA AND EL SALVADOR

1965 AND 1970

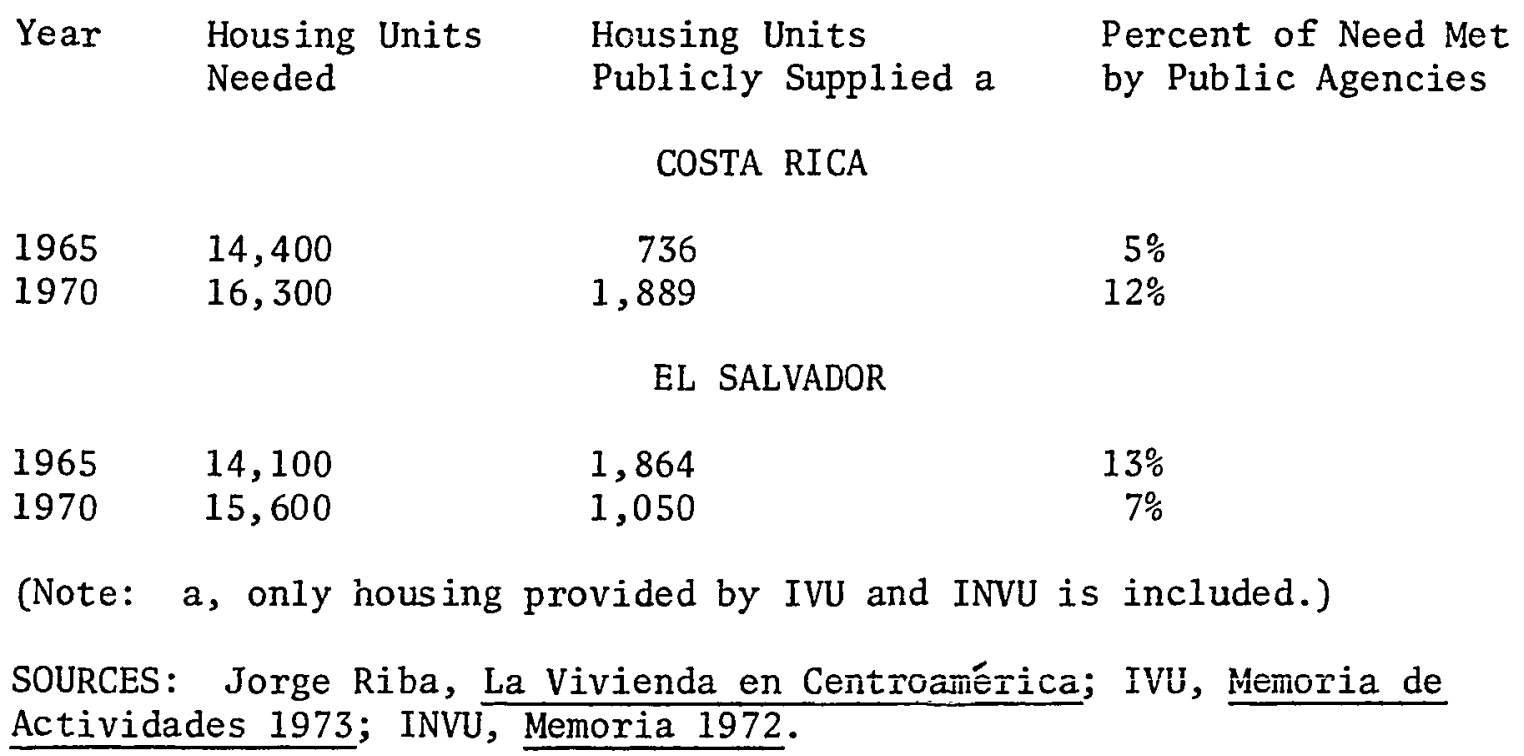

In contrast to Riba's estimates of INVU and IVU performance during the 1960s, Wynia suggests they were able to keep pace:

With little help from the private sector, the housing agencies managed to stay only slightly ahead of the urban population growth. Consequently, at the end of the decade the urban housing deficit remained approximately the same as it had been in 1960.37

There is no disagreement, however, that little of the accumulated 38

housing deficit has been eliminated in either country. Neither

agency any longer defines its targets in terms of eliminating the 39

deficit. IVU sets up construction targets of so much housing

each year for (usually) a five-year period; INVU sets no long-range

targets at all. Only when it has completed preliminary engineering

for a specific project will it make any public statement.

In concluding this comparison of housing practices of IVU and 
INVU, a few points merit further emphasis. One is the difference in the approach to self-help housing. INVU assumed that provision of materials and technical assistance would be sufficient with future tenants providing the will and the labor. This assumption proved false. IVU adopted a more structured approach, with definite scheduling and on-site supervision. This approach worked better, although not perfectly. In fact, most of some unexpected cost overruns suffered by IVU were a result of high administrative costs in its selfhelp program.

One characteristic shared, involuntarily, by INVU and IVU has been severe financial difficulty, the worst of any Central American housing program. Neither agency found its BID and USAID assistance sufficient to establish self-sustaining programs. Both agencies found themselves effectively abandoned by their central governments in times of budgetary shortages. For several years, in fact, the Costa Rican government refused to pay INVU the annual subsidy of $\$ 1,200,000$ due it by 1 aw.

In E1 Salvador, then, the fiscal crisis was due primarily to unexpected administrative costs and secondarily to inadequate Central Government support, both exacerbated by BID insistence on completion of self-help housing before any further loans would be considered. In Costa Rica the crisis was due primarily to lack of promised Central Government funding and secondarily to unexpectedly expensive self-help housing costs. These were exacerbated by USAID and BID insistence that before they would disburse further loan money, existing projects had to be completed and the Central Government had to meet 
its obligations.

In spite of everything, IVU and INVU have been the two most successful housing agencies in Central America at actually providing dwelling units. They have been the most ambitious, undertaken the largest projects, and encountered the greatest difficulties. Their specific construction practices, financing arrangements and clientele selection have been compared above; Chapter VIII will examine briefly the larger aspects of housing policy and policymaking in Costa Rica and EI Salvador.

\section{MUNICIPAL REVENUE}

In this section the current revenue and expenditure patterns of the two municipalities are considered. They are compared not only with one another but also with de Moraes' ideal of good municipal revenue practices. In addition, some of the findings of Arvids Kalnins, United Nations municipal revenue specialist, on administrative shortcomings in San José are presented.

\section{$\underline{\text { San Salvador }}$}

The chaotic, almost anarchic, state of San Salvador's municipal revenue system has been detailed above in Chapter VI. Nowhere is this more evident than in the budget. Municipal revenues are obtained from the following general sources:

1. Taxes on capital investment

2. Taxes on economic activities carried on in public places

3. Taxes on public entertainment and raffles

4. Taxes on construction

5. Charges for municipal services 
6. Fees for 1 icenses and permits

7. Fines

8. Charges for market stalls.

As noted above, no such logical categories are used in the Tarifa. Nor are they in the budget. Over 95 percent of current income is lumped under the single catch-a11 category of 'Regular Income.' The reason for this imprecision is simple: municipal authorities do not know how much they can expect from any particular tax or charge, nor from any group thereof.

In fact, the preparation of the budget is almost exclusively concerned with the expenditure side. First, the Municipality figures out what it is going to do and how much it will cost to do this. Except for large specific projects, this is the same as the previous year, modified slightly to account for wage increases and higher cost of materials. Next, the total of any expected subsidies, donations and special fees is calculated. This latter amount is subtracted from the former. The amount then needed to balance the budget, it is assumed, will somehow come from the Municipality's olio of taxes and charges. The dangers of this approach to budgeting are recognized by the Municipality. In the preamble to the budget, a statement warns citizens of possible service cutbacks and employees of possible layoffs if, for any month, it looks like expenditures are too high or revenues are underrealized.

It is reasonable to assume that most of San Salvador's regular income comes from the taxes on capital investment and construction. These activities are carried on by larger corporations who presumably engage in accurate bookkeeping even if the Municipality does not. 
These corporations, moreover, tend not to be political allies of the PDC. The Municipality therefore can collect from these taxpayers more easily and cheaply than it can track down hosts of sidewalk vendors, particularly when these vendors do tend to be political supporters of PDC. This particular tax collection practice, it will be remembered, underlay much of CACI's suspicious and hostile attitude towards San 45

Salvador.

In summary, then, the revenue side of San Salvador's budget is shown in Table XXVIII.

TABLE XXVIII

MUNICIPALITY OF SAN SALVADOR, CASH ON HAND AND PROJECTED REVENUE 1973 (\$C.A.)

Income from own sources

Regular

Special Funds

Fines

Subsidies

Cash on Hand
$\$ 2,864,076$

43,622

3,168

2,164

162,164

$\$ 3,075,194$

Total

SOURCE: Municipalidad de San Salvador, Presupuesto Municipal 1973.

It should be noted that these figures do not include income from the municipal markets. These are governed by their own 1 aw and by the 47

loan agreement with BID. Interestingly enough, the City Markets

Law permits the markets manager much greater financial latitude than that possessed by the Municipality generally. For example, the manager can spend up to $\$ 8,000$ without the Vo.Bo. of the Central Government; San Salvador can spend only $\$ 2,000$. The Municipality is re- 
quired to spend some of its general fund money on market administration. In 1973 it had $\$ 81,500$ earmarked for this purpose.

If the revenue side of San Salvador's budget is vague and unimformative, the expenditure side is much more thoroughly and completely presented. Table XXIX presents the expenditures for 1973 both by category of expenditure and by nature of service provided.

TABLE XXIX

PROPOSED SAN SALVADOR MUNICIPAL EXPENDITURES, 1973 (\$C.A.)

By Expenditure Category

\section{Category \\ Wages and Salaries \\ Services \\ Supplies \\ Equipment \\ Construction \\ Transfer Payments}

Total
Amount

$\$ 1,938,504$

411,260

217,223

129,000

80,000

299,208

$\$ 3,075,194$

By Service Category

Financial Administration

Sanitation

Public Works

General Administration

Police

Community Action

Slaughterhouse

Other

Total
$\$ 1,118,482$

548,575

531,132

265,480

165,966

98,344

92,270

254,945
$\$ 3,075,194$
Percent

63.0

13.4

7.1

4.2

2.6

9.7

100.0

SOURCE: Municipalidad de San Salvador, Presupuesto Municipal 1973.

Expenditures in the category Financial Administration would be considered overstated in United States municipal accounting practice. For example, all bookkeeping and data processing costs for the whole mu- 
nicipal operation are included here, not costed out and charged to the respective departments.

Probably the most striking aspect of the San Salvador municipal budget is its small size. A budget of just over $\$ 3,000,000$ is not very much for a city of over 500,000 population. 48 To be sure, many functions generally regarded as municipal are performed (or not performed) in San Salvador by other agencies. Streets are constructed by DUA and water and sewers provided by ANDA, to mention just two of these. Nonetheless, the usual condition of the Municipality of San Salvador is one of penury.

San José

Municipal revenue sources in Costa Rica are quite diverse, and the quality of the collection practices is uneven. The chaos that reigns in San Salvador is absent but the Costa Rican system is still exceedingly complex. In addition to charges for municipal services, municipal revenue sources may be divided into those available to all municipalities and those restricted to only certain municipalities.

The basic levies made by all municipalities include taxes on real estate, public spectacles, and construction; license charges for carrying on various commercial and industrial activities; three different liquor taxes; municipal stamps; and fees for the slaughtering of swine and cattle. The livestock-slaughtering fee for an animal is to be split evenly between the municipality where it was finished and the one where it was slaughtered. Of these taxes, al1 but the license charges are covered by generic national laws setting conditions and rates that are constant throughout the country. A special law is 
needed for each municipal license charge on industrial or commercial activities.

A variety of taxes is levied by only some municipalities, in some cases by only one. These include taxes on land left vacant or unproductive, sugar, tobacco, salt, mangrove wood, lobsters, turtle harvesting, wood, petroleum, cement and graves. Most of these taxes are governed by general national laws but each grave or wood tax requires a specific act of the National Assembly.

One further complication that existed through 1969 was the web of relationships between municipalities and the Central Government. The two levels had shared in a variety of real property, coffee, Iiquor and ad valorem taxes. New legislation effective January 1, 1970 , modified this so the municipalities shared among themselves the total 49

proceeds of the property tax. San Jose's share is fixed at 29.4 percent of the amount collected. The Central Bank collects this tax and takes 8.6 percent for administrative costs. The remaining 62 percent is divided among all other municipalities in the country according to population. The importance of this revenue source, and the relative position of others, is shown in Table $\mathrm{XXX}$.

The role played by parking meter revenue in San José has been discussed above in Chapter VI. It should be mentioned that in one way or another the Municipality derives almost $\$ 200,000--a b o u t$ five percent of its income--from various fees and charges on the manufacture, import and sale of liquor.

The absolutely critical contribution of the real property tax 51 to San José municipal coffers, then, is evident from the table. 
Almost 50 percent of its total income ( 73 percent of its tax revenue) is derived from this source. Moreover, the collection costs are nil. The Central Bank does the collecting and pays San José the Municipality's share off the top, even before subtracting its administration fee.

TABLE XXX MUNICIPALITY OF SAN JOSE, PROJECTED REVENUE, 1974 (\$C.A.)

Source

Property tax a

License fees

Other taxes

Total tax revenue

Rental of market space

User charges

Subsidies b

Fines

Other non tax revenue $c$

Total non tax revenue

Total revenue
Amount

$\$ 2,185,298$

439,245

284,528

$\$ 2,909,071$

205,087

909,665

163,900

128,429

64,906

$\$ 1,471,986$

$\$ 4,381,057$
Percent

49.9

10.0

6.5

66.4

4.7

20.8

3.7

2.9

1.5

33.6

100.0

(Note: a, almost 98 percent of this amount is from the real property tax, the remainder is from a real estate transfer tax and the tax on vacant land; $b$, almost 99 percent of this amount is from IFAM; $c$, a franchise fee of five percent of gross revenue is levied on the electric company.)

SOURCE: Municipalidad de San José, Presupuesto Ordinario del 1974.

One other point merits inclusion here. Despite the ruling of the Comptroller General and the drawn out fight for its approval as an impuesto, parking meter revenue is classified in the budget as a user charge, not as a tax.

Table XXXI presents the expenditure side of the budget by nature of expenditure and by program. As was the case for San Salvador, 
Wages and Salaries account for most of the Municipality's expenses. More specific comparisons between the two cities will be made below in a subsequent part of this chapter. Before ending our consideration of San José and its budgetary and financial practices, it is worth examining the administrative shortcomings identified by Kalnins, along with some of his suggestions for improvement.

TABLE XXXI

PROPOSED SAN JOSE MUNICIPAL EXPENDITURES, 1974 (\$C.A.)

By Expenditure Category

Category

Wages and Salaries

Services

Supplies

Equipment

Acquisition of Real Estate

Transfer Payments

Debt Service
Amount

$\$ 2,433,323$

497,907

747,548

51,943

16,906

560,561

72,869

$\$ 4,381,057$
Percent

55.5

11.4

17.1

1.2

0.4

12.8

1.7

100.0

Total

By Program Category

Policy Development and

Planning

General Administration a

Municipal Health

Education and Culture

Economic and Social Services

Public Works

Capital Investment

Total

$\begin{array}{rr}\$ 378,231 & 8.6 \\ 1,090,290 & 24.9 \\ 855,195 & 19.5 \\ 223,890 & 5.1 \\ 414,000 & 9.4 \\ 578,190 & 13.2 \\ 841,261 & 19.2 \\ & \\ \$ 4,381,057 & 100.0\end{array}$

$\$ 378,231 \quad 8.6$

24.9

19.5

5.1

9.4

13.2

9.2

00.0

(Note: a, financial services account for $\$ 779,957$ of this amount.)

SOURCE: Municipalidad de San José, Presupuesto Ordinario del 1974.

The most basic deficiency Kalnins found to be the "complete ab- 
sence of recent and valid technical studies about the administrative, juridical, financial and fiscal situation of the municipalities of Costa Rica." 53

Many of the conditions he criticized have been improved. His criticisms were, in some cases, instrumental in bringing about needed change. He complained, for example, that there existed no Municipal Code, that there was a hodgepodge of tax sources shared between municipalities and the Central Government, and that there was no central clearing house or course for technical or financial aid or advice to the municipalities. All of these have changed for the better.

Some conditions, however, have not changed. Kalnins found, as 54

did Castro Carvaja1, that municipalities paid insufficient attention to budgeting and were constantly plaguing the Comptroller General with requests for modifications, as often as 15 times a year for some municipalities. Municipalities continue to overspend their budgets, user charges remain unrealistically low and the Comptroller General persists in impeding fiscal planning with his rigid insistence on invariable line-item budgets from the municipalities.

Kalnins offered a rather radical solution to the administrative and financial problems of the subnational units of government in Costa Rica. These units should be abolished and the country divided into 14 56

departments. Each department was to be purely an administrative arm of the Central Government. In this suggestion his French background comes to the fore. Provinces and cantons have not been abolished in Costa Rica. They continue to exist, to have severe administrative difficulties and to grapple with financial problems. 57 San José is 
not exempt from the municipal maladies.

Summary

In this section San José and San Salvador are briefly compared on four points: actual size of municipal government, revenue sources and collection, expenditure patterins, and quality of tax system according to de Moraes.

Size of budget is often used as a measure of scope of municipal activity. San José's budget is larger than San Salvador's, about 40 percent larger. This is so despite the fact that San José serves approximately 20 percent fewer people. Municipal government in San José, then, is considerably more expensive on a per capita basis-about 11 dollars as compared with six dollars per capita in San Salvador. As befits the more populous city, San Salvador has the larger municipal workforce--1,805 employees to San José's 1,376. In both municipalities there are roughly 3.5 municipal employees for every 1,000 inhabitants. Municipal employees are better paid in San José where they earn an average (mean) of $\$ 1,768$ per year than in San Salvador where $\$ 1,074$ is the mean annual income.

Tables XXVIII and XXX above indicate the sources of revenue for the two municipalities. Several factors are immediately evident. Both cities have very low revenues, total and per capita, by North American standards, and jan Salvador is considerably lower than San José. Most of this difference is accounted for by the property tax which generates half of San José's revenue and nothing in San Salvador. Another factor, already mentioned, is the availability of park- 
ing meter revenue in San José. Closely tied to this is the productivity of fines. Fines, almost half of which are parking fines, provide almost three percent of San José's revenue but only one-tenth of one percent in San Salvador.

The difference in the level of central government support is obvious. Less than one-tenth of one percent of San Salvador's income comes from subsidies while San José receives almost four percent from this source. Moreover, the turnover of the property tax to the municipalities by the Costa Rican government can almost be regarded as a 61 massive subsidy.

Finally, it should be emphasized that San José's more careful estimate of revenue from the various sources allows the preparation of a more realistic budget. Revenues due from a particular source may be more accurately assessed and remedial action taken more quickly should they drop unexplainedly below estimates. This is not to suggest that San José's monitoring and revenue collection practices are effective and efficient. Far from it--San José like other Costa Rican municipalities is inexcusably lax in the collection of user charges. But as woeful as the quality of revenue collection is, it is still better than in San Salvador.

Meaningful comparison of the expenditure patterns of the two municipalities is rendered difficult by the different package of services each offers its citizens. The most obvious differences are that San José constructs and maintains roads while San Salvador does not, and that San Salvador maintains a municipal police force whereas San José has none. 
Nonetheless, a few useful comparisons may be made. Both cities spend about the same portion of their income on General Administration and in safeguarding the health of their citizens. Both are required to transfer about ten percent of their funds to other agencies such as school boards.

The largest single difference between the two is that while San José puts almost one-fifth of its income into Capital Investment, less than three percent of San Salvador's income is directed to new construction. Interestingly enough, San Salvador, which does not build or maintain roads, spends more of its revenues on Public Works than San Jose, which does build and maintain roads. Finally, Culture and Economic and Social Services use up about 15 percent of San José's income while the closest comparable category in San Salvador, Community Action, gets only three percent. This is explained in large part by the more centralized and activist role of FOCCO when compared to DINADECO. Municipal expenditure patterns, then, like so many other facets of municipal activity in the two countries, are heavily influenced by the nature of national-municipal relations.

These relations are reflected, among other considerations, is the relative standings of San José and Sani sâivador vis-a-vis de Moraes' developmental paradigm. ${ }^{63}$ De Moraes, it will be remembered, classifies municipal tax systems as current, transitional and future. Characteristics of the current system include utilization of patrimonial natural resources, taxes and charges on things and persons, and imposition ad speciem. Consequences of this system are a static economy, deficient public services and a strong tendency to centrali- 
zation.

The next developmental stage he labeled transitional. This step is characterized by prevalence of taxes and user charges, income according to the concepts of increased rates and earmarking, some cases of double imposition, charges as a function of capacity to contribute, and imposition ad valorem. De Moraes suggested the consequences of moving to this stage would be augmentation of financial capacity, improvement in service delivery and a tendency to decentralization. His future stage is we1l beyond the reach of either San José or San Salvador and will not be considered further here.

One point de Moraes might profitably have included in his developmental scheme was administrative progress in tax collection from the current hit-or-miss approach toward some future system characterized by efficiency, equity and impossibility of evasion. It may well be that improved administration procedures could do more than any modification of the tax structure itself to aid the municipalities fiscally. We see below some steps toward improving the nature of revenue policies; no such steps in improving administration can be detected. However brilliantly designed a revenue system may be, uncollected tax monies cannot pay for any services.

In a very real sense, then, all the attempted municipal revenue policymaking we have examined has been an effort to move from current to transitional systems. San José's parking meter law, for example, 64

did impose a tax or user charge and did augment the Municipality's financial capacity. It also improved service delivery in two ways: directly, through provision of more orderly parking arrangements, and 
indirectly, through provision of more money to the City Treasury to pay for other services.

San Salvador's attempted tax reform was a broad front effort to move from ad speciem to ad valorem levies and very specifically, to make charges a function of capacity to contribute. As de Moraes suggested, some cases of double imposition would have resulted.

Nonetheless, both municipalities today have tax systems that are classified as current. In both cases, there remains a strong tendency toward centralization. We would have to disagree with de Moraes, however, in his contention that this tendency is a consequence of the current tax system; rather, we submit, it is a contributing factor thereto. This tendency, moreover, is not as strong in San José as in San Salvador. According to any of de Moraes' criteria, San José is farther along the road to a transitional, hence better, tax system than is San Salvador.

The greatest financial boon to San José in recent years has undoubtedly been the transfer of the real property tax. This was, however, an act of the Central Government. There is no evidence that the Municipality initiated any action to effect this transfer.

A major difference in style can be noted in practices, particularly intergovernmental fiscal relations, in Costa Rica and E1 Salvador. In El Salvador the Central Government aims to keep the capital both politically and financially weak. There are two proper places for money to be concentrated, it feels--in its own hands or in the private sector. Costa Rica makes no such attempt to keep its municipalities either politically impotent or destitute. The Central 
Government has shown itself willing to provide the municipalities with money. Ultimately, however, it maintains control of this money. Taxing capacity has not passed to the municipalities. The Costa Rican government does not keep San José broke. It does keep it, rhetoric to the contrary, financially dependent. In the final analysis we must question just how much, if any, difference these two styles actually make to San José and San Salvador in their attempts to develop rational, adequate, equitable local government revenue systems.

This chapter, then, has examined the current practices and programs in the fields of municipal revenue and public housing provision in San Salvador and San José. Chapter VIII will consider the broader nature of policymaking in these fields and relate this back to both the political, economic, and social background factors and to our original hypotheses and models for analysis. 
CHAPTER VII NOTES

1. Costa Rica, Instituto Nacional de Vivienda y Urbanism (INVU), E1 INVU: Organización, Objectivos, El Problema de Vivienda, Realizaciones Fisicas, El Planeamiento Urbano, San Jose, 1973, p. 3.

2. Costa Rica, Law Establishing the National Institute of Housing and Urbanism, Article 6c.

3. Many banana growers on the Caribbean slopes abandoned their land when Sigitoka and Panama disease blighted their crops. Unused portions of large landholdings owned by multinational corporations are often taken over by squatters. The Colonization Institute (ITCO) has legalized this use and sometimes makes parcels of land available to INVU for housing lots. Squatters have use of the land and after successfully working it for a number of years may get title to it. Many squatters, however, sell land to which they have no title to North Americans, who are subsequently dispossessed.

4. INVU, E1 INVU, p. 5 .

5. INVU, Memoria 1972, San José, 1973, p. 31. Wynia, however, reports that 70 percent of INVU's clients were at least three months behind on their mortgage payments in 1967 (Politics and Planners, p. 160).

6. INVU, Memoria 1972, p. 32 .

7. Ibid., p. 28 .

8. INVU, E1 INVU, p. 8 .

9. In addition to INVU, other housing finance agencies are Banco Credito Agricola de Cartago (loans for rural housing construction only), Banco Anglo Costarricense, Banco de Costa Rica, Banco Nacional de Costa Rica, Instituto Nacional de Seguros, Banco Popular y de Desarollo Comunal, and Caja Costarricense de Seguro Social. Caja's policy changes unpredictably. Some years it makes low-cost, subsidized loans fairly widely available, other years it finances only housing for its own employees.

10. Unofficial estimate by various staff members of IVU.

11. E1 Salvador, Instituto de Vivienda Urbana (IVU), Memoria de Actividades 1972-1973, San Salvador, 1973, unpaged. 
12. Oscar Rene Salegio, Análisis de la Situación y del Plan Habitacional, San Salvador, IVU, 1968, pp. 47-80 passim.

13. Ibid., p. 70 .

14. Sean M. E11iot, Financing Latin American Housing: Domestic Savings Mobilization and U.S. Assistance Policy (New York: Frederick A. Praeger, 1968), p. 144 .

15. Salegio, Análisis, p. 71 .

16. A thorough perusal of the Salvadorean Constitution failed to identify the applicable articles.

17. San Salvador (E1 Salvador) La Prensa Gráfica, 22 April 1974, p. 33.

18. IVU, Memoria 1972-1973.

19. Wynia, Politics and Planners, p. 162.

20. Salegio, Análisis, p. 79.

21. In the mid-1960s the Legislative Assembly recommended that IVU build very low-cost rental units for tugurio dwellers. IVU ignored this recommendation as being totally unrealistic and fiscally irresponsible.

22. In one press release, for example, IVU announced construction of 60 single-family dwellings for teachers, nurses and employees in the 27th of September Colony in Zacatecoluca at a total cost of $\$ 292,515$. Each dwelling would contain 128 square meters of floor space, more than twice the size of minimum housing units (La Prensa Gráfica, 28 January 1974, p. 44).

23. Fundación Salvadoreña de Desarollo y Vivienda Minima (FUNDASAL), El Carretón de los Sueños, San Salvador, Moderna Noble \& Asociados, 1973, p. 21 .

24. Ibid., p. 25 .

25. La Prensa Gráfica, 19 Apri1 1974, p. 7.

26. La Prensa Gráfica, 26 February 1974, p. 3.

27. For example, La Prensa Gráfica, 4 April 1974, p. 23, carried an article on the donation of $\$ 15,000$ worth of electrical wiring materials by Phelps Dodge of Central America.

28. It is an interesting anomaly that IVU, an agency of a secular government, generally insists that its tenants be formally married, while FUNDASAL with a Roman Catholic priest as executive 
director, asks only that there be some evidence of stability in the relationship.

29. Interview with Antonio Ibañez, 19 April 1974.

30. While exact figures are not available on the distribution of the 90 percent of the votes not cast for PCN they did not all go to PDC. MNR received a larger share of the votes than its share in the country as a whole. Much of the information in this section was gathered in March, April and May, 1974 from informants who did not care to be identified.

31. Time, 24 July 1978, p. 72.

32. For example, projections of the urban housing deficit in El Salvador for 1980 range from 140,000 to 697,500 units.

33. White, El Salvador, p. 247.

34. Jorge Ricardo Riba, La Vivienda en Centroamérica, San Salvador, Secretaria General del Organización de Estados Centroamericanos, 1969 , p. 35 .

35. Riba's estimates of total deficit are very close to those in UNICEF, Las Sociedades Centroamericanas Actuales. Riba, however, bases his projections on a growth rate of 3.8 percent for Costa Rica and 3.3 percent for E1 Salvador when the most recent figures show El Salvador at 3.9 percent and Costa Rica at around two percent. To be consistent his estimates for El Salvador would have to be increased and those for Costa Rica decreased.

36. Koth, Housing in Latin America, p. 38.

37. Wynia, Politics and Planners, p. 178.

38. One set of optimistic figures, however, does suggest that the accumulated deficit is being successfully attacked in the San José area. Antonini, Public Policy, p. 67, offers the following:

Total Housing Deficit

San José Province

San José Urban Area

1963

25,938

9,729

1970

19,200

5,958

Change

$-6,738$

$-3,751$

$\%$ change

$-26 \%$

$-39 \%$

39. There is a persistent rumor in San Salvador that the Central Government suppressed a report on the progress of public housing 
because it documented the embarrassing failure of IVU to even approach its goals.

40. Wynia, Politics and Planners, p. 180 .

41. United Nations Office of Technical Cooperation, Evaluación del Desarollo del Programa Sobre 1a Reorganizacion Administrativa y Financiera de Régimen Municipal de Costa Rica, prepared by Arvids Kalnins, San Jose, 1972.

42. Municipality of San Salvador, Presupuesto Municipal 1973, San Sa1vador, 1973. Unless otherwise indicated, all references to budget in this section are to this document.

43. See above, p. 222 .

44. As detailed and rational as the Municipality's proposed tax reform was, it did not estimate total revenues from particular sources either.

45. At the time PDC had adopted as a slogan: "So he who has more, pays more and he who has less, pays less." CACI suggested that the slogan should read: "Who pays his taxes on time has the capacity to be taxed twice as heavily."

46. E1 Salvador, City of San Salvador Markets Law (1969).

47. San Salvador, with E1 Salvador acting through CONAPLAN as guarantor, borrowed $\$ 6,300,000$ in 1969 to construct seven new municipal markets. The City Markets Law was passed primarily to make this possible.

48. The City of Portland, by contrast, had in 1977-1978 a general fund budget of $\$ 104,700,000$ for a city of 400,000 population.

49. Costa Rica, Law Number 4340, 30 May 1969.

50. Costa Rica, Ministerio de Gobernación, Nuestro Gobierno y E1 Régimen Municipal, San José, Imprenta Naciona1, 1972, p. 24.

51. It can readily be seen why Vargas in "Administración del Sistema Municipal" ascribes much of the strengthening of Costa Rican municipalities to Law 4340. See p. 34 above and Chapter II, notes 57-59.

52. Kalnins, Reorganización Administrativa y Financiera del Régimen Municipal en Costa Rica, San José, Oficina de Planificación, 1968.

53. Ibid., p. 2 .

54. Castro Carvajal, "Evaluación del Sistema Presupuestaria." 
55. Kalnins also criticized the 14-year 'gestation period' of the Urban Planning Law. See the discussion above, Chapter VI, of the time required for the Parking Meter Law.

56. Kalnins, Reorganización Administrativa, p. 64.

57. The Comptroller General regularly condems individual municipalities for profligacy and other financial sins. On one day in 1973 for example, he declared 83 municipalities "financial disasters" for cumulative overspending of some $\$ 300,000,000$ (La Nación, 21 November 1973, p. 4A).

58. It will be remembered that population figures are not gathered for the municipalities but for the urban areas of the respective provinces. For comparative purposes here San Salvador is assumed to have a population of 500,000 and San José of 400,000. See above, Chapter $V$, for actual head count figures for the urban areas.

59. Both figures are obtained by adding departmental figures listed in the respective budgets. The San José budget goes so far as to list the name and salary of employees paid on a monthly or annual basis.

60. These figures compare very favorably with general per capita income in the two countries. In 1970, per capita income was $\$ 469$ in Costa Rica and $\$ 298$ in El Salvador. See above, p. 174.

61. If the Salvadorean government followed the lead of Costa Rican and gave the capital 29.4 percent of the property tax, San Salvador's share (1972) would amount to $\$ 1,074,570$. Compare this to the actual municipal revenue in 1973 of $\$ 3,075,194$.

62. The Central Government's record in property tax collection is not much better.

63. See above, pp. 90 and 91 .

64. Again, it is still unresolved whether the parking fee is a tax or a user charge.

65. IFAM, for example, may take off from the top of any municipality's share of the property tax, any amount owed to IFAM by the municipality. 


\section{CHAPTER VIII}

\section{CONCLUSION}

Our analysis has shown that for our first general premise the null hypothesis held (p. 11). That is, we found no significant difference in policymaking and policy outcomes between San José and San Salvador in the fields of revenue raising and public provision of housing. We do not conclude from this, however, that the political, social and economic background factors considered are irrelevant, only that they need be more carefully examined. Our focus in this section, then, is on those background factors that are similar in the two cities. We will attempt to determine the extent to which these similar factors explain the similarities in policy.

The broadest and most important of the policy similarities are the paucity of revenue decisionmaking and the absence of public housing decisionmaking in both San Salvador and San José. As this condition is more readily explained for housing, this will be done first.

Stated simply, in both cases the central government has reserved to itself the provision of public housing. It might be recalled here that the Salvadorean Municipal Act did not mention housing provision but Article 41-5 of the Costa Rican Municipal Code requires municipalities to "establish... housing programs of social interest" in the urban areas. Despite this statutory difference, the two countries' public housing practice closely parallel one another. Major 
reasons for national rather than municipal (or cooperative nationalmunicipal) provision are iterated briefly below.

In the first place, housing in El Salvador and Costa Rica is not primarily an urban problem. Estimates of the exact size of the housing problem vary according to whose data and projections are used so definitive figures are almost impossible to obtain. Nonetheless, there is considerable evidence that housing shortfall and substandard housing, both in absolute numbers and as percentages, are greater in the rural areas of Costa Rica and El Salvador than in the urban areas. The national and rural dimensions of the need for the public provision of housing therefore make it a concern of the central and not of the municipal governments. As shown in Chapter VII, however, most of the housing provided by the national governments agencies, INVU and IVU, is provided in urban areas. The greatest concentration, moreover, is in the metropolitan regions of the capital cities.

In most places and for most issues problem areas and political boundaries do not coincide. This is particularly true of urban housing problems in Costa Rica and E1 Salvador. Unlike the United States where urban housing decay and shortfall are associated generally with the central city, the segments of the urban population most in need of housing assistance in Central American are found on the fringes of the city. Thus the problem, and the housing-short population, spills over from one jurisdiction into another. The problem is, then, at least metropolitan in scope. Lacking both effective intermediate government units and intermunicipal cooperation, the central governments are required almost by default to do whatever is to be done 
about the provision of publicly assisted housing in urban as well as in rural areas.

Cost and financing considerations also lead to centralization. The municipalities simply do not have the fiscal capacity (partly for reasons offered in the section on revenue raising) to provide the amounts of publicly assisted housing required within their own boundaries. But for that matter neither do the national governments. It is necessary, therefore, to seek external financing. External donors may, in some cases, be willing to deal directly with the cities. Lenders, however, provide the overwhelming bulk of external financing, and external lenders, whether private financial institutions, other nations, or international agencies, insist upon the participation of the central governments. Since national governments, then, are required to guarantee loans and back the municipalities with full faith and credit, they simply go the one step further and do it themselves. For the central governments to assume the ultimate financial responsibility for public housing without taking direct control, makes very little sense to them.

Yet other reasons for direct central government provision of housing lie in the fact that housing is not provided in a policy vacuum. Housing policies are related to other national policies, and often have aims and goals beyond the mere provision of shelter. National governments obviously need pay more attention to externalities, positive and negative, than municipal corporations. Housing policy is logically connected to industrial location and may be used to discourage migration to larger cities and to encourage settlement 
elsewhere. Construction of public housing may spur local building materials industries and result in the creation or upgrading of marketable skills among the workers. Moreover, housing may be used for political purposes. Among these are providing low-cost housing to civil servants and building projects in areas where the populace seems most ready and able to engage in disruptive and destabilizing political activity. Surely it is in the best interests of the national governments to control public housing and hence maximize their influence over these various occurrences.

Nor have the municipalities given the central governments much reason for faith in local abilities to set and administer housing policy. In neither San José nor San Salvador is there any evidence of past efforts to alleviate the housing problem. Part of this inactivity is of course due to lack of funds but part of it must be attributed to lack of will or interest or both. The head of the engineering department of IVU, speaking of public sector participation in the provision of housing in urban El Salvador, states:

The Central Government has taken charge of all the public housing programs and projects in the country and the participation at the level of the local Governments or Municipalities has been to date practically nil.1

In looking at revenue raising we will see that this suspicion of municipal administrative competence is not totally unjustified.

Yet another impetus to central government takeover of urban housing provision is structural. Both Costa Rica and El Salvador have used autonomous or semi-autonomous agencies of the national government to provide what are usually regarded as urban services. Both countries have such agencies in the field of electricity, water and 
sewage, public health añd urban planning, to mention a few. Thus there js a tradition, and a style, of national government involvement in local services and the extrapolation to urban housing provision is an easy and obvious one.

These, then, are some of the explanations for the central governments' assumption of urban public housing policy. But what have the central governments done in this field, what has been their policy response? In both cases the basic activity, as might be expected, has been the establishment of a national authority. In neither case does this authority, INVU in Costa Rica and IVU in E1 Salvador, include a representative from the municipal sector.

The various construction policies of these agencies have been detailed above; they need not be elaborated further here. One very important policy decision as to clientele, however, deserves emphasis. In both cases the conscious and overt decision has been made to provide housing primarily for the middle to lower-middle class, those who can almost but not quite compete in the private housing market. A variety of reasons is offered for this. One is the purely financial. Because this clientele can and presumably does pay their rent and repay their loans, the drain on the treasury is less and in the long run, more housing can be provided for the same amount of government money. Another reason is that many of the people so helped are relatively skilled personnel, e.g., nurses, teachers, technicians, and the governments find it desirable to keep them as satisfied as possible.

Yet another explanation may be found in the governments' 
conviction that providing housing alone to the very lowest classes does as much harm as good. The result of this would be a still unemployed, poor, hungry, sick and geñeraily hopeless population living in a different place. Experiences such as those with the superbloques in Caracas indicate that this attitude may not be as callous as it first seems.

In all of the above we have examined commonalities in urban public housing policy between El Salvador and Costa Rica. There do exist a few differences, however. The partisan political animus between San Salvador and the central government does not exist in Costa Rica. This difference may be felt more than specified or explained in housing policies and practices. In addition there exists in E1 Salvador a private, non-profit agency known as the Salvadorean Foundation for Development and Minimum Housing (FUNDASAL). This agency tackles the entire problem area of 'marginality,' part of which is the provision of housing. FUNDASAL builds housing for sectors of the population unable to meet the minimum income requirements of IVU. It estimates that more than 90 percent of the Salvadorean population can afford, on a long-term basis, the housing it provides. There is a good deal of cooperation between FUNDASAL and the Municipality of San Salvador; the Municipality, for example, donated the land upon which FUNDASAL built one of its housing projects. It should be noted that the central government has also aided, with cash payments, FUNDASAL projects. No parallel organization exists in Costa Rica. The closest is yet another autonomous agency of the national government, the Mixed Institute for Social Aid (IMAS). Like FUNDASAL it is headed up by a 
Catholic priest and receives some donations from the private sector. IMAS does engage in limited slum clearance and housing rehabilitation. Unlike FUNDASAL, IMAS is primarily a social work agency and has a predominantly rural, not urban, orientation. When approached by a poor migrant to the city for help, IMAS' first inclination is to help him back to the countryside; FUNDASAL's is to integrate him into the urban community. Also unlike FUNDASAL, IMAS has no ties to or cooperative agreements with the municipality. IMAS provices a minimal amount of urban housing as a last resort; FUNDASAL sees the provision of housing to the urban poor as a prime responsibility.

One further difference between Costa Rica and El Salvador lies in the institutional arrangement of their housing agencies. INVU is not a part of any Ministry but an "autonomous organism of the State, endowed with its own funding, legal personality and administrative and technical independence." In El Salvador, on the other hand, IVU is but one of five agencies under the Technical and Coordination Directorate of the Ministry of Housing and Urbanization. INVU, then, is free to pursue its aims with minimal control or interference from any other agency. IVU lacks this freedom but is more likely to find its efforts integrated in and subsidiary to a broader overall national plan for urban development.

Finally, the Municipality of San Jose has begun a study of the possibility of providing cheap housing for the lowest paid municipal employees. No such moves have been undertaken by San Salvador.

In furthering our study of housing policies, it might prove instructive to compare Costa Rica and El Salvador on each of the 
thirteen objectives suggested by Abrams (above, p. 101).

The first suggested objective is priority in housing for lowerincome families. Both governments' housing policies adhere to this to some extent. For reasons stated above, briefly in this conclusion and more fulling in the body of the paper, neither government concentrates on housing for the lowest income families. Costa Rica, however, aims at a clientele whose poorest members have lower incomes than the poorest members of the target group in E1 Salvador.

Opportunities for homeownership by low-income families at low costs are provided for in both countries' policies. Again, Costa Rica tries to minimize the costs more than does E1 Salvador. Both countries concentrate more on housing ownership than on rental opportunities.

Choices of environment provided by govermment housing projects are somewhat constrained in each of the two countries. Both offer choices in the 'stage-of-construction' realm--furnished houses, shells and urbanized lots are available. Not all types are available in all projects however. The important difference here is that some rental housing is provided in El Salvador, none in Costa Rica.

Both countries' housing policies include reasonable financing policies. El Salvador provides financing for both single-family dwellings and low-income condominiums. Costa Rica makes financing available for the purchase of government-assisted housing, paying off high interest rate mortgages, purchase of building lots, and buying land in cases where a homeowner has built his home or someone else's property. 
Savings are encouraged within government housing policy in both cases. In El Salvador the government chooses to work through the private sector with FNV aiding in the establishment of savings and loan associations. The Costa Rican government has opted for building the savings incentive, and the facilitative mechanism, right into the housing agency.

Subsidies are more difficult to compare cross-nationally, but in neither case can they be regarded as adequate. The central government in El Salvador was asked to provide IVU with a guaranteed annual subsidy. It refused. The Costa Rican government, on the other hand, is required by law to provide INVU with an annual subsidy. However, its failure to honor this legal mandate has been mentioned above. An interesting point of comparison here is that the Salvadorean government has provided a subsidy for the private FUNDASAL while the Costa Rican government has made no such grant to a ron-government agency.

A more effective building industry does not seem to have developed in either country. Costa Rica has accepted whatever state of technology exists in the private firms with which it contracts. El Salvador, on the other hand, has actively sought and encouraged experimental proposals from its contractors and has originated and tested some products in IVU's own material technology section. El Salvador has, therefore, made more of an effort in this direction than has Costa Rica but no effective results have been seen to date. Consequently, in neither country has there been any significant reduction in home construction costs due to government housing policy. Placement of industry where a minimum of housing needs to be 
built is not a particularly relevant objective in either Costa Rica or E1 Salvador. Costa Rica has encouraged decentralization of industry to a greater extent than El Salvador, but not by much. There is literally nowhere in either country a labor intensive industry could 1ocate with sufficient housing for its work force. This, therefore, has not been a prime factor for industrial location or housing policy in either country.

Rehousing of squatters per se has not been a major priority of housing policy in either case. Neither Costa nica nor El Salvador has adopted a policy of trying to move an entire colony of squatters to government-assisted housing on a fixed schedule. Squatter resettlement has been carried out on a piecemeal basis and in neither country has it been an activity of the housing agency.

Little has been done to prevent squatting in either Costa Rica or El Salvador. This is the case despite a very different 'squatting environment'; squatting is not a critical problem in Costa Rica whereas it accounts for some two-thirds of the urban growth in E1 Salvador. Moreover, squatting is no longer regarded as an unmixed evil. Current thinking is that squatting is to be guided, not eliminated.

Formal housing cooperatives in the European tradition are unknown in the two Central American countries, and no government policies exist to foster them. Cooperation in housing construction, however, is not unknown as overnight erection of large shantytowns demonstrates. Salvadorean government housing policies encourage mutual aid by tenants-to-be in the construction of some housing projects. This practice was also tried by INVU in Costa Rica but was not found 
viable and has been abandoned. Neither government has adopted rent control policies.

In summary, then, the two national governments have a very similar set of housing policies. In neither case do they regard housing as a strictly urban policy area. Costa Rican housing policy, set by INVU, has its particular strengths in its wider financing provisions and consideration of the needs of a lower-income group than in E1 Salvador. This latter nation, however, is stronger in its provision of low-income rental housing and its efforts to develop cheaper and more efficient building materials.

With the unreliability of statistics and differences in program operation, it is difficult to state that one country's set of policies has been the more effective in the provision of shelter to those unable to compete in the private housing market. It is even more difficult to tie a measure of success back to the set of political, social and economic factors examined. To the extent possible, however, this has been done above in the body of the paper.

It is fair to say, nevertheless, that neither E1 Salvador nor Costa Rica has made any substantial progress in housing its lowerclass urban population. It is not fair to concentrate attention solely on the shortcomings of national housing policy. In the face of severe financial and political difficulties, each nation has provided some housing. And, it should be repeated, Costa Rica and E1 Salvador are far ahead of the other Central American nations in this respect. Both countries' housing programs suffer from the twin handicaps of scarce capital and surplus clientele. Both countries found it 
necessary to seek external financial aid, and international funding agencies, with some recent and partial exceptions, have subscribed to the "devil take housing" theory:

According to this theory, housing merits low priority in national and international spending schemes because it is a durable form of investment requiring substantial outlays but paying off little per year. In addition, it generates no foreign exchange, competes with industry and agriculture for capital, draws off needed labor and materials, and may even be inflationary. 3

Internally, problems with national housing programs have been primarily problems related to the overall national political milieux more than to IVU or INVU shortcomings.

International funding agencies, it seems, expect little from housing programs. In fact, they seem to anticipate failure. These gloomy predictions tend to become self-fulfilling.

In the final analysis, as long as Costa Rica and El Salvador depend on external sources of capital, the attitudes and practices of these outside actors are going to affect the public provision of urban housing more than will any internal political, social or economic conditions or the nature of the policymaking process in the two countries and any of their local governments.

In examining the revenue policies of San José and San Salvador, similarities rather than differences come to the fore. In both municipalities many initial attempts were made to broaden the revenue base; few were successful. Our difficulty in finding specific examples to follow through the process is symptomatic of this. In both cities, the major snags came in the legitimation phase; that is, the problem arose of obtaining needed central government approval. The successful 
case examined, parking meters in San José, indicates the complexities in getting the national government's Vo.Bo. for a project of no apparent possible conflict with national policy. In the unsuccessful case looked at, overall tax reform in San Salvador, the same sorts of difficulty were found, exacerbated by the active and effective opposition of the business community.

Where, then, and to what background factors do we look to explain the similarity in, and paucity of, municipal revenue policy? Foremost among the political factors we must consider national control of the municipal fisc. In both cases we saw this manifested in two overarching legal requirements: one, that the municipal budget be approved by a central government agency; and two, that local taxes be enacted as laws by the Legislative Assembly before coming into effect. Both San Salvador and San José exhibited severe problems in the administration of their revenue policies, particularly unsure and erratic tax collection, a condition not likely to encourage the national governments to grant further taxing powers.

National governments in E1 Salvador and Costa Rica have been stable for over 25 years. This has given them time to concern themselves with municipal problems; they have not had to devote large percentages of governmental energy imposing internal order. As a result they may feel less inclined, and less compelled, to assign the municipalities more responsibilities and concomitant revenue sources.

Another relevant similarity is that of style in administrative decentralization. Certain services, local in nature, are viewed as not appropriate for direct central government provision, yet are too 
expensive for the cities to handle. Instead of providing revenues, or at least enabling legislation for increased local revenue raising, the governments create autonomous agencies. With the provision of these services thus out of the hands of local government, so allegedly, are the needs for increased revenue.

In both countries, elections, contested by recognizable parties, determine control of national and municipal governments. Policy preferences of local government leaders, therefore, are not purely personal and idiosyncratic but are ideological as well as pragmatic. Despite differences in partisan make-up of the municipal council, both San José and San Salvador have sought changes in local revenue policy. Both have been rebuffed by their central governments.

Non-governmental groups have played a part in shaping local revenue policy in the two cities. In both cases this role has been primarily obstructionist. And in both case these external actors have met with success by intervening with the national government at the legitimation stage of the process more than by influencing the local government during the policy formulation phase.

Not all the similarities in background factors affecting the similarity in policy output, however, are political; some are economic. Perhaps the most important of these is the similarity we have observed in national tax structures. Both concentrate heavily on indirect taxes. The failure of the central governments to make widespread use of direct taxes may somehow lead to a reluctance to approve additional local taxes which are for the most part direct.

General structures of the national economies, as measured by 
the structure of the Gross Domestic Product, parallel one another very closely in Costa Rica and El Salvador. The same is true of the mix of public and private economic activities in the generating of the gross domestic products. A direct link between these factors, however, and the policy outcomes we have observed, does not imnediately suggest itself.

A further economic similarity is income distribution. Since groups of one income level tend to support increased municipal revenues (and expenditures) and those of another income level tend to oppose sucin increases, the similarity in income distribution may account for the closely matched patterns--that is, the patterns of attempted increases at the local level in both countries and the blocking of these attempts at the national level.

Two demographic factors look very much alike in San José and San Salvador--the age structure of the population and the numerical preponderance of women. A link between these factors and the policy statements of the municipal governments could be posited if it could be shown that women and/or the dominant age groups held a consensus opinion on the need for more municipal revenue, and that one or both of these groups were especially active politically. But there is no such evidence, and thus nothing to support speculation as to the existence of such a linkage.

This, then, is a brief listing of the background factors that are similar in the two polities and hence likely to lead to similarities in policy outputs. But not all political, economic and social conditions are this similar in the two countries. Here we will 
consider briefly the ones that vary significantly, the ones we originally hypothesized would account for expected differences in policy. Several of these characteristics are economic. It was shown above in the section on economic background factors that the Costa Rican economy was growing faster, had a greater percentage of its workforce in manufacturing, and a considerably lower unemployment rate. Per capita productivity was also higher in Costa Rica. El Salvador, it was noted, endured a much smallex rate of inflation. None of these major differences, however, led to the expected variation in policy output, even in local government revenue raising where they were expected to have the most influence.

Among the demographic and social dissimilarities we note the greater urban population growth in EI Salvador. And, although the data are incomplete and even suspect, this country shows a higher rate of internal rural to urban migration. Some differences in community structure have also been examined.

Political diversities were expected to result in and explain the largest part of our anticipated variation in policy output. One of these diversities is the greater degree of openness of the Costa Rican political system; though this openness is difficult to measure and document, it is nonetheless very real. Another is the divergence, legislatively and administratively, between the two municipal government organizations.

The single set of political differences expected to generate the most variety in policy product is the set of relationships between 10cal and national governments. Three aspects vary significantly. In 
Salvador there are virtually no subsidies paid the local government in San Salvador by the nation; in Costa Rica these subventions are considerable. The Costa Rican government assigns a major and important, if undefined, role in national development to local governments. No such posture is assumed by the Salvadorean government. In Costa Rica the same spectrum of political parties is found in the National Assembly as in the San José council. In El Salvador the capital is pitted in total partisan political opposition to the national government. Nonetheless, San José has had as little success in obtaining national approval for tax changes as has San Salvador. We must conclude that ultimately it makes no differences in this particular policy area whether national government practice is to keep the city financially dependent as in Costa Rica or politically weak as in E1 Salvador. Finally, the existence of a comprehensive plan for the development of metropolitan San Salvador was expected to have an effect on policy in that municipality. No such effect is in evidence, among other reasons because the plan assigned local government no role in the development process.

In our discussion of the current municipal tax systems of San José and San Salvador we compared them not only with one another but also with de Moraes' evolutionary model. Having examined the policymaking process, we note attempts on the part of both municipalities to move closer to his developmental paradigm, attempts that have been frustrated by the national governments. San José continues to have, vis-a-vis de Moraes' criteria, a better tax system than San Salvador. De Moraes' model, however, cannot be accepted uncritically. It 
appears, for example, to confuse cause and effect in claiming a tendency to centralization as a consequence of the current municipal tax system rather than a contributing factor thereto. Nonetheless the mode1 does provide a useful summary of the present state of the art and possible alternatives thereto, and remains a convenient backdrop against which to make comparisons.

The policy products and the contributions of the various background factors thereto have been analyzed for San José and San Salvador. It is appropriate at this point to offer some conclusions on their policymaking structure. It is particularly useful to compare them against the tableau of Wynia's seven characteristics, to determine to what extent his national-level stereotypes in Central America are mirrored at the local level.

Wynia's first characteristic is "paternalistic and often charismatic leadership juxtaposed with a lack of institutional, especially constitutional, legitimacy." This type of leadership is definitely found in San Salvador; it is totally absent in San José. Both municipal policymaking structures, however, possess institutional legitimacy.

Expanding political participation yet underrepresentation of the masses is found in both cities. Both, however, are trying to broaden the base of mass participation. The motivating force behind these attempts vary significantly. In Costa Rica the national government has mandated the opening of the local political structure to community residents. In San Salvador the municipality itself has tried to encourage the participation of the hoi polloi, largely to provide 
votes and workers to aid UNO-CD national political aspirations.

The extensive patronage ascribed to administrative structures is found in both cities, as are the intricate formal rules. In neither case, however, does there appear to be as widespread an informal disregard for these rules as is found at the national levels. One characteristic of the local administration deserving mention here is the difficulty, in both cases, of attracting qualified personnel to fill upper-level administrative and technical positions.

Obscured and obstructed communications within the public sector are to be found in San José and San Salvador. This is more true of national-local government relations than of intra municipal contacts. Each polity exhibits its own special case of this. In San José the breakdown seems to occur due more to weak information or functional area rivalries between local government and autonomous agencies; in San Salvador it is another manifestation of the political-ideological conflict between the municipality and the national government. Communication problems between municipalities and the private sector in both circumstances have two bases: a tendency of the sectors to talk past one another and a preference on the part of the private sector for political contacts at the national rather than the local level. Neither heavy reliance on the private sector for managing but not financing economic growth nor slow economic growth and modernization due to structural and institutional rigidities have any direct relevance to local policymaking. Rigidities built into national government, however, do affect the localities. There seems to be no less of this in the one situation than in the other despite a rhetoric of 
flexibility on the part of the Costa Rican government.

Again, economic dependence on foreign markets and consequent vulnerability to external economic and financial conditions do not impinge as directly upon the local as on the national policymaking structures. A closely related condition, however, is found in external lending agency controls on the structure of public housing provision. Since the rules promulgated by the external agencies are general, there are no differences in their applicability between El Salvador and Costa Rica.

Wynia has suggested further that associated with the particular Central American decisionmaking structure will be found one of two kinds of policymaker--the overcautious, underinformed, hesitant incrementalist, and the utopian of infinite goodwill but minimal understanding of complex policy problems. We did not find municipal policymakers in either city at these extremes. We did find, however, the policymakers in San José to be more incremental and realistic in approach while those in San Salvador were somewhat more holistic, and even idealistic.

In Chapter I it was suggested that we might expect to find a 'consensual elite' situation in San Salvador and a 'competitive mass' in San José. A 'consensual elite' structure is characterized by a narrow distribution of political power among the citizens and a convergence of political ideology among political leaders. San Salvador definitely exhibits a concentration of political power but does not manifest any unity of ideology among political leaders, particularly when the actual roles of economic notables and the national govern- 
ment in local politics are considered. More accurately then, its power structure should be labeled 'competitive elite.' San José also shows a divergence among ideologies of political leaders but in its more open system, power is more widely dispersed among a larger proportion of the citizenry. Our supposition as to a 'competitive mass' in San José, then, holds true but our expectation of a 'consensual elite' in San Salvador does not.

Finally, it remains to comment briefly on the suitability of our policymaking model. It has worked. Not only the policy approach but our scheme in particular have proved compatible with comparative inquiry. Our model is not, however, beyond needing improvement.

One modification that would improve its usefulness is the inclusion of a legitimation phase between adoption and application. Obviously we have not ignored legitimation in the sense of approval of policy by the national government, but the inclusion of a formal 1 egitimation stage in the model would serve two purposes. First, it would make the model more consistent with the reality of the policymaking process in the Central American republics, and 1ikely elsewhere. Second, it would alert other potential users of the model to the importance of formal legitimation in the creation of municipal policy.

Another necessary alteration to our model would provide for cases where demands originate within the political system. Traditionally a major argument in policy analysis has been whether needs or demands entered the policical system. In response the individual analyst has simply shifted the boundaries of the formal political system 
backward or forward along the policy process stream. This practice, we have found, prisduces an inadequate model for comparative purposes. A more complete model must allow for the inclusion of demands generated in the private sector and presented as such to the political system and also for demands generated within the political system. This is particularly true in those polities where government, local or national, functions as patron.

The third improvement to our model would be to build in a mechanism to take cognizance of the roles played by informal actors. Traditional models stress the boundaries of the political system, suggesting that after a certain stage in the process outsiders, those not formally part of the system, take no further part in decisionmaking. This is even less an accurate reflection of reality in Central America than in the 'developed' countries. We emphasize again the role played by private interests in the legitimation phase, a better model would deal more directly with them.

We do not imply that the model usedin this study, modified as above would be perfect. Nonetheless it could provide a useful starting point for those who would do further research in this field. Hopefully, they can and will use it in search of more complete information and fuller explanations.

If our model, with some modifications, served us well, our basic hypothesis did not. We expected to find the differing sociopolitical cultures, acting both directly and through the policymaking activities, leading to substantive differences in both process and product. These differences in process and product did not materialize. 
A variety of possible explanations for this absence offer themselves. The background factors chosen may, in fact, not affect significantly the policy output -- or, they may affect the policy output only in the Anglo-American situation and not in the Central Anerican cases. We are not prepared to accept this radical an explantion without further study.

The background factors may not influence policy and policymaking in the chosen policy areas of public housing and municipal revenue but may have an effect in other policy areas not examined. Unfortunately there are no known studies of this kind on other policy areas which could either support or refute this contention.

It may be that one particular phase of the policymaking process, the administration/application phase, is of such overarching importance that similarities therein overwhelm more subtle differences due to the differing background factors. Of particular importance here might be two elements: the adninistrative structure itself, and the shortage of qualified and motivated individuals serving in critical municipal administration positions. We suggest that this is very likely and offer this particular hypothesis as a base for further examination. Finally, there is a nagging suspicion that city size actually plays a more important role than assigned it in this study. There may be some threshold size, e.g., a population of $1,000,000$, below which our hypotheses do not hold but above which they can be verified. Two lines of further research, therefore, suggest themselves. First, a study along the lines of the current one could be carried out, but with city size adopted as an independent variable. Thus, for example, 
San Salvador might be compared with Caracas or Bogotá. Second, a similar study could be conducted using two large cities with differing social, economic, and political milieux. Bogotá or Caracas, for example, might be compared with Santiago or Buenos Aires.

As stated earlier, one important end of comparative research is the discovery of empirical generalizations that can be verified and eventually become part of an overall explanatory structure. This study is one small step in that direction. Its results were not as expected, and some suggestions have been offered as to why this may be so. Possible modifications and directions for future research have been recommended.

In conclusion, we do not regard studies such as this, in which the initial hypothesescould not be proved, to be fruitless. We maintain that political, economic, and social background factors do affect the nature of both the policymaking process and the outputs therefrom. It is confidently expected that further investigations of this type, with the tools and approaches perhaps refined as suggesied dibove, will be able to verify these hypotheses and provide valid generalizations as to the relations among environmental conditions, political structures and processes, and policy products both in Latin America in particular and third world urban settings in general. 


\section{CHAPTER VIII NOTES}

1. Salegio, Anáiisis, p. 57.

2. Or, more accurately, did offer this choice. INVU no longer provides urbanized lots.

3. Wynia, Planners and Politics, p. 155.

4. See above, p. 20 .

5. See above, p. 10 .

6. Agger, Rulers and the Ruled, pp. 73-78 passim. 


\section{BIB́LIIUGRAPHY}

\section{SOURCES IN ENGLISH}

Abrams, Charles. Man's Struggle for She1ter in an Ubanizing World. Cambridge: MIT Press, 1964.

Agger, Robert E.; Goldrich, Daniel; and Swanson, Bert E. The Rulers and the Ruled: Political Power and Impotence in American Communities. New York: John Wiley \& Sons, 1964.

Agor, Weston H., ed. Latin American Legislatures: Their Role and Influence. Analyses for Nine Countries. New York: Praeger Publishers, 1971.

Alba, Victor. Nationalists Without Nations: The Oligarchy Versus the People in Latin America. New York: Praeger Publishers, 1968.

Anderson, Charles W. "Politics and Development Policy in Central Anerica, "Midwest Journal of Political Science, 5 (1961), 332-350.

Anderson, Thomas P. Matanza: El Salvador's Communist Revolt of 1932 . Lincoln: University of Nebraska Press, 1971.

Antonini, Gustavo A., ed. Public Policy and Urbanization in the Dominican Republic and Costa Rica. Gainesville: University of Florida Center for Latin American Studies, 1972.

Baker, Christopher E.; Fernandez Pinto, Rona1d; and Stone, Samuel Zemurray. Municipal Government in Costa Rica: Its Characteristics and Functions. San Jose: Associated Colleges of the Midwest Field Program and University of Costa Rica School of Political Science, 1971 .

Bauer, Raymond A., and Gergen, Kenneth J., eds. The Study of Policy Formation. New York: Free Press, 1968.

Be11, John Patrick. Crisis in Costa Rica: The 1948 Revolution. Latin American Monograph 24. Austin: The University of Texas Press, 1971.

Beyer, Glenn H. Housing and Society. New York: MacMillan, 1965.

Biesanz, John, and Biesanz, Mavis. Costa Rican Life. New York: Columbia University Press, 1944.

Blum, Walter J., and Kalven, Harry, Jr. The Uneasy Case for Progressive 
Taxation. Phoenix Books. Chicago: University of Chicago Press, $\overline{1965 .}$

Blutstein, Howard I.; Betters, Elinor C.; Cobb, John, Jr.; Leonard, Jonathan A.; and Townsend, Charles M. Area Handbook for E1 Sa1vador. Washington, D.C.: The American University, 1971.

Bodenheimer, Susanne. "The Social Democratic Ideology in Latin America: The Case of Costa Rica's Partido Liberación Nacional," Caribbean Studies, 10 (1971), 49-96.

Booth, John A. "A Replication: Modes of Political Participation in Costa Rica," Western Political Quarterly, 29 (1976), 627-633.

Bowman, Mary Jean. "A Graphical Analysis of Personal Income Distribution in the United States," American Economic Review, 35 (1945), 607-628.

Breton, Albert. "A Theory of the Demand for Public Goods," Canadian Journal of Economics and Political Science, 32, (1966), 455-467.

Browning, David. El Salvador: Landscape and Society. London. Oxford: Clarendon Press, 1971.

Burnett, Ben G., and Johnson, Kenneth F. Political Forces in Latin America: Dimensions of the Quest for Stability. 2nd ed. Belmont, California: Wadsworth Publishing, 1970.

Busey, James L. "Foundations of Politica1 Contrast: Costa Rica and Nicaragua," Western Political Quarterly, 11 (1958), 627-659.

- Latin American Political Institutions and Processes. New

York: Random House, 1964.

- Notes on Costa Rican Democracy. Boulder: University of Colorado Press, 1962 .

Casti1lo, Carlos M. Growth and Integration in Central America. New York: Frederick A. Praeger, 1966.

Chilcote, Ronald H., and Edelstein, Joel C. Latin America: The Struggle with Dependency and Beyond. New York: Schenkman Publishing, Inc. division of John Wiley \& Sons, 1974.

Clark, James. "Environment, Process and Policy: A Reconsideration," American Political Science Review, 63 (1969), 1172-1182.

Cornelius, Wayne A. "Urbanization and Political Demand Making: Political Participation Among the Migrant Poor in Latin American Cities," American Political Science Review, 68 (1974), 1125-1146.

Cuzan, Alfred G. "Urban Resource Allocation and Policy Performance: 
Center-Local Linkages in E1 Salvador and Costa Rica." Paper prepared for delivery to the 1975 Annual Meeting of the American Society for Public Administration. Chicago, April 1-4, 1975.

Dawson, Richard E., and Robinson, James A. "Inter-Party Competition Economic Variables and Welfare Policies in the American States," Journal of Politics, 25 (1963), 265-289.

Denton, Charles F. Patterns of Costa Rican Politics. Boston: Allyn and Bacon, 1971 .

Dewey, John. The Public and Its Problems. Chicago: Swallow Press, n.d. Copyright Mrs. John Dewey, 1954 .

Dickson, Thomas I. "The Contribution of the Inter-American Development Bank to the Latin American Statistics Muddle," Inter-American Economic Affairs, 28 (1974), 79-85.

Dror, Yehezkel. Public Policy Making Re-Examined. San Francisco: Chandler Press, 1968.

Dye, Thomas R. Politics, Economics and the Public: Policy Outcomes in the American States. Chicago: Rand McNally, 1966.

- "Income Inequality and American State Politics," American Political Science Review, 63 (1969 (, 157-162.

- Understanding Public Policy. Englewood Cliffs, New Jersey: Prentice-Hal1, 1972 .

Easton, David. A Framework for Political Analysis. Englewood C1iffs, New Jersey: Prentice-Ha11, 1965.

- A Systems Analysis of Political Life. New York: John Wiley \& Sons, 1965.

Ebe1, Roland H. "Governing the City State: Notes on the Politics of the Sma11 Latin American Countries," Journal of Inter-American Studies and World Affairs, 14 (1972), $325-346$.

- "The Decision-Making Process in San Salvador," in Rabinovitz, Francine, F., and Trueblood, Felicity M., eds. Latin American Urban Research Volume One. Beverly Hills, California: Sage Publications, 1971, 189-213.

Edwards, Harold T. "Power Structure and Its Communication Behavior in San Jose, Costa Rica," Journal of Inter-American Studies, 9 (1967), 236-247.

Elliott, Sean M. Financing Latin American Housing: Domestic Savings Mobilization and U.S. Assistance Policy. New York: Frederick 
A. Praeger, 1968.

Eulau, Heinz. Policy Making in American Cities: Comparisons in a Quasi-Longitudina1, Quasi-Experimental Design. General Learning Corporation Monograph 3002V00, $19 \overline{71 .}$

, and Eyestone, Robert. "Policy Maps of City Councils and Policy Outcomes: A Developmental Analysis," American Political Science Review, 62 (1968), 124-143.

Field, Arthur J., ed. City and Country in the Third World: Issues in the Modernization of Latin America. Cambridge, Massachusetts: Schenkman Publishing, 1970.

Frankenhoff, C.A. "Lơ Cost Housing in a Latin Economy," InterAmerican Economic Affairs, 17 (1964), 79-86.

Fried, Joseph P. Housing Crisis U.S.A. New York: Praeger Publishers, 1971.

Friedman, John, and Alonso, William, eds. Regional Development and Planning: A Reader. Cambridge: MIT Press, 1964.

Froman, Lewis A., Jr. "An Analysis of Public Policies in Cities," Journal of Politics, 29 (1967), 94-108.

Gibson, Jeffry Royle. A Deomgraphic Analysis of Urbanization: Evolution of a System of Cities in Honduras, El Salvador and Costa Rica. Latin American Studies Dissertation Series 20. Ithaca: Cornel1 University, 1970.

Gini, Corrado. "Indici di concentrazione e di dipendenza, "Biblioteca de11' Economista, 5a serie, 20 (1922), 39-40.

Goldrich, Danie1. "Peasants' Sons in City Schools: An Inquiry into the Politics of Urbanization in Panama and Costa Rica," Human Organization, 23 (1964), 328-333.

Gordon, Wende11 C. The Political Economy of Latin America. New York: Columbia University Press, 1965.

Haar, Charles M. "Latin America's Troubled Cities," Foreign Affair $41,(1963), 536-549$.

Hanna, Willjam John. "Comparative Urban Politics," Journal of Comparative Administration, 4 (1972), 265-278.

Haveman, Robert $H$. The Economics of the Public Sector. New York: John Wiley \& Sons, 1970 .

, and Margolis, Julius, eds. Public Expenditures and Policy Analysis. Chicago: Markham Publishing, $19 \overline{70 .}$ 
Hofferbert, Richard I., and Sharkansky, Ira, eds. State and Urban Politics: Readings in Comparative Public Policy. Boston: Litt1e, Brown \& Company, 1971.

Hoos, Ida R. Systems Analysis in Public Policy: A Critique. Berkeley: University of California Press, 1972.

Humes, Samue1, and Martin, Eileen. The Structure of Local Government: A Comparative Survey of 81 Countries. The Hague: International Union of Local Authorities, 1969.

Huntington, Samuel P. Political Order in Changing Societies. New Haven: Yale University Press, 1968.

Institute for the Comparative Study of Political Systems. El Salvador Election Factbook, March 5, 1967. Washington, D.C.: Operations and Policy Research, Inc., 1967.

International Union of Local Authorities. Urbanization in Developing Countries: Report of a Symposium held in December 1967 at Noordwijk, Netherlands. The Hague: Martinus Nijhoff, 1968.

Jacob, Herbert, and Lipsky, Michael. "Outputs, Structure and Power: An Assessment of Change in the Study of State and Local Politics," Journal of Politics, 30, (1968), 510-538.

Jones, Charles 0. An Introduction to the Study of Public Policy. Be1mont, California: Wadsworth Publishing, 1970 .

- "State and Local Policy Analysis: A Review of Progress," in Political Science and State and Local Government. Washington, D.C.: American Political Science Association, 1973, 27-54.

Kantor, Harry. Patterns of Politics and Political Systems in Latin America. Chicago: Rand McNally, 1969.

Kaufman, Clifford. "Urban Structure and Urban Politics in Latin America," Journal of Comparative Administration, 4 (1972), 343-364.

- "A Rejoinder to Joan Ne1son," Journal of Comparative Administration, 4 (1972), 373-379.

Kennedy, Paul P. The Middle Beat: A Correspondent's View of Mexico, Guatemala and El Salvador. New York: Teachers College Press of Columbia University, 197I.

Koth, Marcia N.; Silva, Julio A.; and Dietz, G.H. Housing in Latin America. Inter-American Program in Civil Engineering Research Report R64-04. Cambridge: MIT Press, 1964.

Kraemer, Kenneth L. Policy Analysis in Local Government. Washington, D.C.: International City Management Association, 1973. 
Lasswel1, Harold D. The Decision Process: Seven Categories of Functional Analysis. College Park: University of Maryland Bureau of Governmental Research, 1956. Copied at Ann Arbor, Michigan by University Microfilm, 1972 .

Leontief, Wassily. "Theoretical Assumptions and Nonobserved Facts," American Economic Review, 61, (1971), 1-12.

Lieuwen, Edwin. Arms and Politics in Latin America. Rev. ed. New York: Frederick A. Praeger for the Council on Foreign Relations, 1961 .

Lineberry, Robert L., and Sharkansky, Ira. Urban Politics and Public Policy. New York: Harper and Row, 1971 .

Lorenz, M.C. "Methods of Measuring the Concentration of Wealth," Publications of the American Statistical Association, 9 (1905), 209-219.

Lowi, Theodore. "American Business, Public Policy, Case Studies, and Political Theory," World Politics, 16 (1964), 27-44.

Lundberg, Donald E. Costa Rica. 2nd ed. San José, Costa Rica: Casa Gráfica, 1968.

Martz, John D., ed. The Dynamics of Change in Latin American Politics. Englewood Cliffs, New Jersey: Prentice-Hall, 1965.

- "Costa Rican Electoral Trends 1953-1966," Western Political Quarter1y, 20 (1967), 888-909.

Mayer, Lawrence M. Comparative Political Inquiry: A Methodological Survey. Homewood, Illinois: Dorsey Press, 1972.

Meadows, Paul, and Mizruchi, Ephraim H., eds. Urbanism, Urbanization, and Change: Comparative Perspectives. Reading, Massachusetts: Addison-Wesley Publishing, 1969.

Mehden, Fred R. von den. Comparative Political Violence. Englewood Cliffs, New Jersey: Prentice-Ha11, 1972.

Merritt, Richard L. Systematic Approaches to Comparative Politics. Chicago: Rand McNal1y, 1970.

Mitche11, William E., and Walter, Ingo, eds. State and Local Finance. New York: Ronald Press, 1970.

Musgrave, Richard A. The Theory of Public Finance: A Study in Public Economy. New York: McGraw-Hil1, 1970.

, and Peacock, Alan T., eds. Classics in the Theory of Public Finance. New York: St. Martin's Press, 1967. Copyright International Economics Association, 1958. 
Needler, Martin C. Latin American Politics in Perspective. Princeton: D. Van Nostrand, 1963.

, ed. Political Systems of Latin America. Princeton: D. Van Nostrand, 1964 .

, "The Latin American Military: Predatory Reactionaries or Modernizing Patriots," Journal of Inter-American Studies, 11 (1969), 237-244.

Nelson, Joan. "The Search for Useful Hypotheses," Journal of Comparative Administration, 4 (1972), 365-371.

Nelson, Michael. The Development of Tropical Lands: Policy Issues in Latin America. Baltimore: John Hopkins University Press for Resources for the Future, 1973.

Netzer, Dick. Economics and Urban Problems: Diagnoses and Prescriptions. New York: Basic Books, 1970.

Pan American Union. Constitution of the Republic of Costa Rica 1949 (As Amended). Washington, D.C.: Pan American Union, 1965.

- Constitution of the Republic of E1 Salvador 1962. Washington, D.C.: Pan American Union, 1966.

Paton, Alan. Cry the Beloved Country. Harmondsworth, England: Penguin Books, 1972 .

Payne, Geoffrey K. Urban Housing in the Third World. London: Routiedge ६ Kegan Paul, $19 \overline{76 .}$

Petras, James F., and LaPorte, Robert J. Cultivating Revolutions: The United States and Agrarian Reform in Latin America. Vintage Books. New York: Random House, 1973.

Prest, Alan Richmond. Public Finance in Underdeveloped Countries. 2nd ed. New York: Halstead Press division of John Wiley \& Sons, 1972 .

Rabinowitz, Francine F., and Trueblood, Felicity M., eds. Latin Jmerican Urban Research Volume One. Beverly Hills, California: Sage Publications, 1971 .

Rakoff, Stuart H., and Schaefer, Guenther F. "Politics, Policy and Political Science: Theoretical Altematives." Politics and Society, 1 (1970), 51-77.

Ranney, Austin, ed. Political Science and Public Policy. Chicago: Markham Publishing, 1968.

Ray, Talton F. The Politics of the Barrios of Venezuela. Berkeley: University of California Press, 1969. 
Raynolds, David R. Rapid Development in Small Economies: The Example of E1 Salvador. New York: Frederick A. Praeger, 1967.

Reuber, Grant L. Private Foreign Investment in Development. Oxford: Clarendon Press forthe Organisation for Economic Co-operation and Development, 1973.

Riker, William. A Theory of Political Coalitions. New Haven: Yale University Press, 1962.

Rosenthal, Donald B. "Local Power and Comparative Politics: Notes Toward a Study of Comparative Local Politics." Paper prepared for delivery at the 1972 Annual Meeting of the American Political Science Association, Washington, D.C., September 5-9, 1972.

Ruddle, Kenneth R., and Gillette, Philip, eds. Latin American Political Statistics. Supplement to Statistical Abstract of Latin America 1972. Los Angeles: University of California Latin American Center, 1973.

Rycroft, W. Stanley, and Clemmer, Myrtle M. A Study of Urbanization in Latin America. New York: Office for Research, Commission on Ecumenical Missions and Relations, the United Presbyterian Church in the U.S.A., 1963.

Salisbury, Robert H. "The Analysis of Public Policy: A Search for Theories and Roles," in Ranney, Austin, ed. Political Science and Public Policy. Chicago: Markham Publishing, $19 \overline{68,151-175}$.

, and Heinz, John. "A Theory of Policy Analysis and Some Preliminary Applications." Paper prepared for presentation at the 1968 Annual Meeting of the American Political Science Assocation, Washington, D.C., September 2-7, 1968.

Settlement Study Center. Conference Papers: Rehovot Conference on Urbanization in Developing Countries. Rehovot, Israe1: 1971.

Sharkansky, Ira. "Economic Development Regionalism and State Political Systems," Midwest Journal of Political Science, 12 (1968), 41-61.

, ed. Policy Analysis in Political Science. Chicago: Markham Publishing, 1970 .

Sherwood, Frank P. Institutionalizing the Grass Roots in Brazil: A Study in Comparative Local Government. San Francisco: Chandler Press, 1967.

Singer, Neil M. Public Microeconomics. Boston: Little, Brown \& Company, 1972 .

Smith, Thomas B. "The Study of Policymaking in Developing Nations," Policy Studies Journal, 1 (1973), 244-249. 
Stallings, Barbara. Economic Dependency in Africa and Latin America. Professional Papers in Comparative Politics Volume 3 . Beverly Hills, California: Sage Publications, 1972.

Strickon, Arnold, and Greenfield, Sidney M., eds. Structure and Process in Latin America: Patronage, Ciientage and Power Systems. Albuquerque: University of New Mexico Press, 1972.

Taggart, Robert, III. Low Income Housing: A Critique of Federal Aid. Baltimore: John Hopkins Press, 1970.

Taylor, Charles Lewis, and Hudson, Michael C. World Handbook of Political and Social Indicators. 2nd ed. New York and London: Yale University Press, 1972 .

Time, 24 July 1978 .

United Nations Department of Economic and Social Affairs. Administrative Aspects of Urbanization. (ST/TAO/M/51), 1970.

United Nations Economic Commission for Latin America. Economic Survey of Latin America 1971. (E/CN/12/935/Rev. 1), 1973.

Uphoff, Norman T., and Ilchman, Warren F., eds. The Political Economy of Development: Theoretical and Empirical Contributions. Berkeley: University of California Press, 1972.

Violich, Francis, and Astica, Juan B. Community Development and the Urban Planning Process in Latin America. Latin American Studies Series Volume 17. Los Angeles: University of California Latin American Center, 1967.

Wade, L.L., and Curry, R.L. Jr. A Logic of Public Policy. Belmont, California: Wadsworth Publishing, 1970.

Wagner, Richard E. The Public Economy. Chicago: Markham Publishing, 1973.

Wallich, Henry C., and Adler, John H. Public Finance in a Developing Country: El Salvador -- A Case Study. Cambridge: Harvard University Press, 1951.

Walsh, Vivian Charles. Introduction to Contemporary Microeconomics. New York: McGraw-Hi11, 1970.

Watkin, Virginia C. Taxes and Tax Harmonization in Central America. Cambridge: Harvard University Law School, 1967.

White, Alastair. El Salvador. New York: Praeger Publishers, 1973.

Wickwar, W. Hardy. The Political Theory of Local Government. Columbia: University of South Carolina Press, 1970. 
Williams, Edward J. Latin American Christian Democratic Parties. Knoxville: University of Tennessee Press, 1967.

Williamson, Robert C. "Some Variables of Middle and Lower Class in Two Central American Cities," Social Forces, 41 (1962), 195-207.

- "Some Factors in Urbanism in a Quasi-Rural Setting: San Salvador and San José," Sociology and Social Research, 47 (1963), 187-200.

Wynia, Gary Wayne. "Policy and Bureaucracy in Central America: A Comparative Study." Ph.D. dissertation, University of WisconsinMadison, 1970 .

- "Political Participation and Development Policy Making: Latitudes and Disciplines in Five Central American Systems." Paper prepared for delivery at the MUCIA Conferences on Requirements and Consequences of Political Participation for Development Policies, Center for Continuing Education, University of Chicago, December 5 and 6, 1970 .

- Politics and Planners: Economic Development Policy in Central America. Madison: University of Wisconsin Press, 1972.

\section{SOURCES IN SPANISH}

Government Documents --Costa Rica

Banco Central de Costa Rica. Cifras de Cuentas Nacionales de Costa Rica. (EE/2307/ELB:HBL: ebg/19 June 1973/300). San José, 1973.

Caja Costarricense de Seguro Social. Apuntes Para el Estudio de Uno de los Aspectos de 1a Estratificacion Social en Costa Rica. San Jos'e, 1969.

Costa Rica Comisión Nacional de División Territorial. División Territorial Administrativa de la República de Costa Rica. Edición provisional. San José: Imprenta Nacional, 1972.

Costa Rica Contraloría General de la Republica. Boletín Contralor. No. 7,1972 ; No. 8, 1972; No. 9, 1973. San José.

- Manual Para Establecer, Formular y Presentar el Presupuesto por Programes y Actividades en las Municipalidades de Costa Rica. San José, 1970.

- Memoria Anua1 1972. San José, 1973.

Costa Rica Dirección General de Estadísticas y Censos. Indice de Precios al por Menor. Monthly Journal 1962 - December $\overline{1972 . ~ S a n ~ J o s e ́ . ~}$ 
- Principales Hechos Vitales Ocurridos en Costa Rica 1961-1971. San Jose, 1972 .

San Jose.

- Preliminary Data, 1973 National Census. Unpublished computer printouts.

Costa Rica Imprenta Nacional. La Gaceta -- Diario Oficial. Daily Various Issues. San José.

Costa Rica Instituto de Fomento y Asesoría Municipal (IFAM). Código Municipal y Ley de Organización y Funcionamiento del Instituto de Fomento y Asesorla Municipal. San José: Imprenta Nacional, 1972 .

- Federación Interamericana de Instituciones de Crédito y Asesoria Municipal. San Jose, 1973. 1971

- Filosofía, Objectivos y Programas de Trabajo. San José,

- Manual de Calculo y Cobro de las Tasas por Servicios Urbanos. San Jose, 1973.

- Manual de Contabilidad. San José, 1972.

- Manual y Catalogo de Cuentas Para el Sistema de Contabilidad de las Municipalidades de Costa Rica. San José, 1973.

- Presupesto por Programes Para el Aña 1974. San José, 1973.

- Informa. Month1y December 1971-March 1974.

Costa Rica Instituto Nacional de Vivienda y Ürbanismo (INVU). Como Resolvar Su Problema de Vivienda. San José, 1957.

- El INVU: Organización, Objectivos, E1 Problema de Vivienda, Realizaciones Fisicas, El Planamiento Urbano. San Jose, 1973.

- Ley Organica Instituto Nacional de Vivienda y Urbanismo.

(no. 1788 of 24 August, 1954) San José, 1954.

- Ley de Planificación Urbana. (No. 4240 of 15 November 1968)

San José, 1969 .

- Proyecto de Ley Para Reserva de Terrenos en Hatillo. San José, 1957.

- Sistema de Ahorro y Prestamo. San José, 1972. 
Costa Rica Ministerio de Gobernación. Nuestro Gobierno y E1 Régimen Municipal. San José: Imprenta Nacional, 1972.

Costa Rica Ministerio de Hacienda. Ley de Reforma Tributaría. (No. 4961 of 10 March 1972). San Josê, 1972.

Costa Rica Oficina de Planificación. Guia de Servicios al Ciudadano. San José: Escuela Superior de Administración Publica América Central, 1966.

- Informe de Labores. Annual 1968-1972. San José.

- Previsiones de Desarollo Económico y Socia: de Costa Rica y Planes del Sector Publico Para 1969-1972. San José, 1969.

Costa Rica Tribunal Supremo de Elecciones. Computo de Votos y Declaratorias de Elección Para Presidente y Vicepresidentes, Diputados, a la Asemblea Legislativa, Regidores y Sindicos Municipales. Elections of 1962, 1966, 1970 and 1974. San José.

Instituto Brasileiro de Administração Municipal. Sistema de Planificación Urbana y Regional. Informe Final. San Jose: Instjtuto de Formento y Asesoria Municipal, 1973.

Kalnins, Arvids. Reorganización Administrativa y Financería del Régimen Municipal de Costa Rica. San José: Officina de Planificación, 1968.

- Tributos Municipales Costarricenses: inálisis Critico y Perspectivas. Serie Documentos Municipales. San Jose: Instituto de Fomento y Asesoría Municipal, 1972.

, and Bogantes Hildago, Gerardo. Reorg nización de la Estructura del Gobierno Local de Costa Rica. Si Jose: Oficina de Planificacion, 1969 .

Murilla, Mauro. "Principios Generales de la Competencia Municipal," Revista de 1a Contraloria General de la República 14 (1972), 59-61.

San José, Municipalidad del Canton Central de. Contabilidad de Presupuestos Municipalidades y Concejos de Distritos. San José: Imprenta Naciona1, 1965.

- Licitación Publica No. 22-70. San Jośe, 26 October 1970.

- Presupuesto Ordinario por Programas y Actividades Ejercicio Economico de1 Ano 1974. San José, 1973.

- Unpublished minutes of various council meetings, 1955-1973. 
Government Documents .- El Salvador

Banco Central de Reserva de El Salvador. Revista Mensual. January 1969-March 1974. San Salvador.

Comité Institucional. Diagnostico y Prognostico Habitacional de la República de E1 Salvador. San Salvador, 1971.

Consejo Nacional de Planificación y Coordinación Económica. Indicadores Económicos y Sociales. Quarterly April 1970-April 1974. San Aalvador: Casa Presidencial.

E1 Salvador Dirección General de Estadísticas y Censos. Anuario Estadístico. Annual 1961-1973. San Salvador.

- Boletín Estadistico. Quarterly April 1969-January 1974. San Salvador.

- Censos Nacionales de 1971. San Salvador, June 1972.

- El Salvador en Graficas 1973. San Salvador, 1973.

- Encuesta de Ingresos y Gatos Familiares. (Familias de Ingresos Menores de Seiscientos Colones) Area Metropolitana. San Salvador, 1972 .

- Proyecciones de Población 1961-1981. San Salvador, 1964.

E1 Salvador Instituto de Vivienda Urbana (IVU). Ley de Creación de1 Instituto de Vivienda Urbana. Decree No. 111 of 29 December 1950. San Salvador, 1951.

- Memoria de Actividades. Annual1y 1958, 1961-1967, 1972, 1973. San Salvador.

E1 Salvador METROPLAN. Estudios Sobre los Tipos de Viviendas Predominantes en la Ciudad de San Salvador y Sus Alrededores. San Salvador, 1968 .

E1 Salvador Ministerior del Interior. Diario Oficial. Daily. Various issues. San Salvador.

- Ley de la Financiera Municipal. Decree No. 68 of 1 September, 1966. San Salvador, 1966.

- Ley de Mercados de la Ciudad de San Salvador. Decree No. 312 of 27 April 1969. San Salvador, 1969.

- Ley del Ramo Municipal (Con sus Reformas hasta 1971). San Salvador: Imprenta Nacional, 1971.

- Ley del Régimen Políitico. San Salvador: Imprenta Nacional, 
1970 .

E1 Salvador Ministerio de Obras Publicas. San Salvador: Plan de Desarollo Municipal. San Salvador, (1973).

Salegio, Oscar Rene. Análisis de la Situación y del Plan Habitacional de El Salvador. San Salvador: Instituto de Vivienda Urbana, 1968 .

San Salvador, Municipalidad de. Presupuesto Municipal 1973. San Salvador, 1973.

Other Sources in Spanish

Arias Sánchez, Ocsar. Grupos de Presión en Costa Rica. San José: Editorial Costa Rica, 1971.

Banco Interamericano de Desaro110. El BID y la Vivienda. Washington, D.C., 1957.

- Reunion Sobre Financiamento Municipal en Latinoamérica. Proceedings of meeting held in Washington, D.C. January 23-26, 1966. Three volumes. Washington, D.C., 1966.

Barahona Herrera, Rodrigo. "Organización, financiamento y administrción de Instituciones Nacionales de Crédito Para los Gobiernos Locales." Unpublished study for the Department of Public Administration of the Division of Technicai Assistance of the United Nations. San José, 1967, mimeographed.

Barbosa Roca, Carlos. Contabilidad Publica y Organización Administrativa. Costa Rican National Course for Administrators. San José, $\overline{1971 .}$

Brenes Villar, Carlos Roberto. "Aspectos Historicas Jurídicos del Régimen Municipal Costarricense." Graduating thesis, Faculty of Economics and Social Sciences, University of Costa Rica. San José, 1970.

Cabezas Masses, Ramiro. Eiementos de Administración y Política Tributaria Para Gobiernos Municipales. Caracas: Fondo Editorial Común, 1970.

Caplan, Benedicto. Fianzas Municipales. CICAP-OEA Project 214. San José: Centro Interamericano de Capacitación en Administración Publica, 1971.

Carazo Odio, Rodrigo. "Exposición a III Congreso Nacional de Municipalidades e Costa Rica," Revista Municipal Interamericana, 8 (1958), 62-64. 
Cardona Gutiérrez, Ramiro, ed. Migración y Desarollo Urbano. Proceedings of the Second National Seminar on Urbanization held in Bogotá May 15-18, 1969. Bogotá: División de Estudios de Población de la Associación Columbiana de Facultades de Medicina, 1970.

Castro Carvajal, José Manuel. "Evaluación de Sistema Presupuestario de Costa Rica." Graduating thesis, Faculty of Economics and Social Sciences, University of Costa Rica. San José, 1969.

Castro L., Manue1 Ange1. "Normas Tributarias del Código Municipal y Sus Relaciones con el Nuevo Código Tributario," Revista de Ciencias Juridicas, 20 (1972), 57-62.

Centro Interamericano de Administradores Tributarios. Documentos e Informes de1 I Seminario Técnico Sobre Auditoria Tributaria. Meeting held 25 January-2February 1969 in San José. San José, 1969 .

- Informe del Seminario Regional Sobre Politica Tributaria: San Jose, Costa Rica, 6-10 August 1973. San Jose: Instituto Centroamericano de Administración Publica, 1973.

Chávez Mena, Fidel. "Organización Municipal." Doctoral thesis, Faculty of Jurisprudence and Social Sciences, University of E1 Salvador. San Salvador, 1966.

- "La Migración Interna," Ateneo, 260 (1969), 62-77.

Escuela Superior de Administración Publica América Central. Estado de la Opinion Publica de Costa Rica Sobre el Gobierno Municipal. Serie Trabajos de los Alumnos No. 15. San José, 1959.

- Informe de Seminario Sobre un Estudio Comparativo de Conceptos y Terminos Aplicables al Regimen Municipal en Centroamérica. Serie Informes de Seminarios No. 3 San José, 1960.

- Estudio Comparativo de Sistemas Tributarios de 105 Paises Centroamericanos. Serie Economia y Fianzas No. 416. (ESAPAC' EXT/014/200/66) San José, 1966.

Fundación Salvadorena de Desarollo y Vivienda Minima. E1 Carretón de los Sueños. San Salvador: Moderna Noble \& Asociados, 1973.

Garcia Vargas, Gonzalo. "Control Económico Fianciero de las Municipales Costarricenses." Graduating thesis, Faculty of Economics and Social Sciences, University of Costa Rica. San José, 1966.

Garro, Joaquin. Veinte Años de Historia Chica. (Notas Para una Historia Política Costarricense). San José: Imprenta Vargas, 1968.

Gomez B., Miguel. Informa de la Encuesta de Fecundidad en el Area Metropolitana. San José: Universidad de Costa Rica--Instituto 
Centroamericano de Estadística, 1968.

Harth Deneke, Alberto. "1954-1973: 20 Ã̃os de Planes Para San Salvador," Revista Interamericano de P1anificación, 7 (1973), 64-76.

Heredero Higueras, Manuel. Las Estructuras de Organización de la Administración Urbanistica. Madrid: Escuela Nacional de 1a Administración Public, 1968.

Instituto Centroamerican de Administración Publica. Estructura y Administración Tributaria de América Central. San José, 1968.

Instituto Centroamericano de Estadistica. Tablas de Vida de Costa Rica 1962-1964. Serie Economia y Estadística No. 24. San José: Universidad de Costa Rica, 1967.

Jiménez, Mario Alberto. Desaro11o Constitucional de Costa Rica. 2nd ed. San José: Editorial Costa Rica, 1973.

Jiménez Castro, Wilburg. Migraciones Internas en Costa Rica. Washington, D.C.: Pan American Union, 1956.

Lope-Bello, Nelson Geige1. Autonomia Municipal y Urbanismo. Caracas: Universidad Simon Bolivar Instituto de Estudios Regionales y Urbanos, 1972 .

Martinez Calvo de Angelé, 01ga. "Problemas Socio-Economicos Que Afectan al Peon de la Municipalidad de San José." Graduating thesis, School of Social Service, University of Costa Rica. San José, 1972 .

Meza Araya, José Rafael. "La Potestad Reglamentaria Municipal." Graduating thesis, Faculty of Law, University of Costa Rica. San José, 1972.

Montero Umaña, Lilia Maria. "Evolución del Sistema Tributaria de Costa Rica y Analisis Economico de Algunos Impuestos al Consumo Interno." Graduating thesis, Faculty of Economics and Social Sciences, University of Costa Rica, San José, 1972.

Moraes Barreto, Joao Luiz de. "En Busca de una Teoria de Reforma Tributaria Municipal en América Latina," Revista de Ciencias Jurídicas, $20(1972), 105-114$.

Muri11o, Mauro. "Participación de ios Munícipes en el Gobierno Local," Revista de Ciencias Juridicas, 20 (1972), 105-115.

San José (Costa Rica) La Nación. Daily. Various Issues.

Novoa, Fidel A. Asi se Construye una Ciudad. San Salvador: By the Author, no date. 
Obregon Loria, Rafael. E1 Poder Legislatvia en Costa Rica. San José: Imprenta Naciona1, 1966.

Oficina Internacional de Trabajo. Situación y Perspectivas del Empleo en Costa Rica. Geneva, 1972.

San Salvador (E1 Salvador) La Prensa Gráfica. Daily. Various Issues.

San José (Costa Rica) La Prensa Libre. Daily. Various Issues.

Ramirez A., Mariano. La Determinación de 1a Población Economicamente Actica y Su Distribución por Rama de Actividad: El Caso de Costa Rica. San Jose, no date.

Ramirez Zamora, Luis Edgardo. "Investigación de los Servicios Pub1icos Brindados por las Municipalidades y Sus Lineas de Acción." Graduating Thesis, Faculty of Economics and Social Sciences, University of Costa Rica. San José, 1972.

Riba, Jorge Ricardo. La Vivienda en Centroamérica. San Salvador: Secretaría General de La Organización de los Estados Centroamericanos, 1969 .

Rodriguez Monge, Cecelia, and Ferrer de Beck, Elena Teran. "Aspectos Historicos y Urbanos de Area Metropolitana de San José de Costa Rica." Graduating thesis, Faculty of Sciences and Letter, University of Costa Rica, San José, 1967.

Rojas, Otto. "E1 Código Municipal y la Municipalidad Autónoma. Subvenciones y la Autonomía Municipal," Revista de Ciencias JurIdicas, 20 (1972), 9-56.

Romero Pérez, Jorge-Enrique. "El Primer Código Municipal de Costa Rica," Revista de Estudios de la Vida Local, 1977 (1973) unpaged.

- "El Instituto de Fomento y Asesoría Municipal de Costa Rica," Revista de Estudios de la Vida Local, 1979 (1973) unpaged.

Salas, Jośe Maria. Le Reforma Municipal y el VI Congreso Interamericano de Municipios. San José, 1957.

Sancho Gonzales, Eduardo. "Las Funciones Municipales (Artículo 4 del Código Municipal) y la Realidad Municipal Costarricense," Revista de Ciencias Juridicas, 20 (1972), 63-103.

Santoro, Gustavo. Algunos Aspectos de la Vida Urbana en San José. Serie Ciencias Jurídicas y Sociales No. 6. San Jose: Universidad de Costa Rica, 1962.

Sariola, Sakari. Análisis Socio-Economico de Barrio "Sagrada Familia" Area Recien Urbanizada de San José de Costa Rica. Universidad de Costa Rica Serie Trabajos de Alumnos No. 10. San José: Escuela 
Superior de Administración Publica America Central, 1958.

Solorzano Saenz, Mercedes. "El Hecho Generador de La Obligación Tributaria." Graduating thesis, Faculty of Law, Univerisity of Costa Rica. San José, 1971.

Spósito Jiméñez, Luis Alberto. Curso Basico de Contabilidad Municipal. Caracas: Fondo Editorial Común, 1970.

Stone, Samuel Zemurray. "Algunos Aspectos de la Distribución del Poder Político en Costa Rica," Revista de Ciencias Jurídicas, 20 (1972), 105-130.

United Nations Children's Emergency Fund; Secretaría Permanente del Tratado General de Integración Economica Centroamericana; and Organización de Estados Centroamericanos. Las Sociedades Centroamericanas Actuales: Análisis y Surgencias Para la Planificacion de Sus Desarollos, Tomando en Cuenta la Formacion de Sus Nuevas Generaciones. Guatemala: Editorial José de Pineda Ibarra, 1972.

- Informe Final: Conferencia Sobre la Familia, la Infancia y la Juventud de Centroamérica y Panama. Guatemala: Editorial Jose de Pineda Ibarra, 1973.

United Nations Department of Economic and Social Affairs. Financiamiento de los Programas de Vivienda y de Mejoramiento de Ia Comunidad. (E/CN.5/323-ST/SOA/32) New York, 1957.

United Nations. Economic and Social Council. Aspectos Demograficos y Socioeconomicos del Area Metropolitana de San Salvador. Prepared by J. Van denBoomen. (E/CN.12/CCE/333/TAO/LAT/54). San Salvador, 1 January 1966.

United Nations. Office of Technical Cooperation. Evaluación del Desarollo del Programa Sobre la Reorganizacion Administrativa y Financiera del Regimen Municipal de Costa Rica. Prepared by Arvids Kalnins. San Jose, 1972.

United States Agency for International Development and Fundación Para la Vivienda Cooperativa. Mesa Redonda Sobre el Problema de la Vivienda en las Urbanizaciones Marginales. Proceedings of meeting held in Washington, D.C. November 3-7, 1969. Washington, D.C., 1970.

Universidad de Costa Rica. Algunos Aspectos Sociograficos de Area Metropolitana de San José. Proyecto Estratificación No. 1. San Jose: Centro de Estudios Sociales y de Poblacion, 1970.

Varga Oviedo, José Angel. "Administración del Sistema Municipal en Costa Rica." Graduating thesis, Faculty of Economics and Social Sciences, University of Costa Rica. San José, 1972.

Vega Calvo, Johnny. "Régimen Jurídico de la Prestación de Servicios 
Publicos Locales." Graduating thesis, Faculty of Law, University of Costa Rica. San José, 1965. 
APPENDIX A

GLOSSARY OF ACRONYMS

There exists in Central America a large number of government agencies, political parties, international organizations and miscellaneous groups that are universally known by the acronyms for their Spanish names. Below are the most common, with English equivalents. Full Spanish names have been provided above when first encountered in the text.

\section{Costa Rica}

Political Parties

\begin{tabular}{ll} 
AD & Democratic Action Party \\
CD & Christian Democratic Party \\
PASO & Socialist Action Party \\
PLN & National Liberation Party \\
PNI & National Independence Party \\
PRD & Democratic Renovation Party \\
PRN & National Republican Party \\
PUAC & Cartagenan Agricultural Union Party \\
PUCR & Civic Revolutionary Union Party \\
PUN & National Unification Party \\
& \multicolumn{1}{c}{} \\
Other Agencies & Interinstitutional Commission on Nomenclature \\
CIN & General Office for Medical and Social Assistance \\
DIGAMS & General Office for Community Development \\
DINADECO & Costa Rican Electrical Institute \\
ICE & Institute for Strengthening and Assisting Munic- \\
IFAM & ipalities \\
IMAS & Consolidated Institute for Social Assistance \\
INS & National Insurance Institute \\
INVU & National Housing and Urbanization Institute \\
OFIPLAN & National Planning Office (attached to the Presi- \\
& dency)
\end{tabular}




$\begin{array}{ll}\text { SNAA } & \text { National Sewer and Water Administration } \\ \text { TSE } & \text { Supreme Election Tribunal } \\ \text { ANFE } & \text { National Association for Economic Development } \\ \text { ANDE } & \text { National Teachers Association } \\ \text { FECR } & \text { Federation of Costa Rican University Students } \\ \text { ANEP } & \text { National Association of Public Employees } \\ \text { JUDECA } & \text { Coffee Growers Federation } \\ \text { ITCO } & \text { Colonization (Rural Resettlement) Institute }\end{array}$

El Salvador

Political Parties

$\begin{array}{ll}\text { FUDI } & \text { United Democratic Independent Front Party } \\ \text { MNR } & \text { National Revolutionary Movement Party } \\ \text { PCN } & \text { National Conciliation Party } \\ \text { PCD } & \text { Christian Democratic Party } \\ \text { PPS } & \text { Salvadorean Popular Party } \\ \text { PRUD } & \text { Revolutionary Democratic Unity Party } \\ \text { UDN } & \text { Democratic Nationalist Union Party } \\ \text { UNO } & \text { United Opposition Party }\end{array}$

Other Agencies

$\begin{array}{ll}\text { ANDA } & \text { National Sewer and Water Administration } \\ \text { CAESS } & \text { San Salvador Electric Streetlighting Company } \\ \text { CONAPLAN } & \text { Nentral Election Commission } \\ \text { DUtional Council for Planning and Economic Coordi- } & \text { nation } \\ \text { FINAMUN } & \text { Directorate of Urbanism and Architecture } \\ \text { FOCCO } & \text { Munjipal Development Bank } \\ \text { FNV } & \text { Office for Community Development and Self Help } \\ \text { FUNDASAL } & \text { National Housing Finance Administration } \\ & \text { Salvadorean Foundation for Development and Minimum } \\ \text { ICR } & \text { Housing } \\ \text { IVU } & \text { Institute for Rural Colonization } \\ \text { MOPT } & \text { Institute for Urban Housing } \\ \text { TEGEFEM } & \text { Ninistry of Public Works and Transportation } \\ \text { FUSS } & \text { General Treasury for Municipal Funds } \\ \text { FESTIAVSCES } & \text { United Trade Union Federation } \\ \text { Federation of Food, Clothing and Related Trade } & \text { Unions } \\ \text { CGS } & \text { General Confederation of Trade Unions } \\ \text { AGEUS } & \text { National Union of Christian Workers } \\ \text { COSDEC } & \text { General Association of University Students } \\ \text { ANDES } & \text { National Coffee Marketing Association } \\ \text { ANEP } & \text { National Teachers Association } \\ \text { CACI } & \text { National Association of Private Enterprises } \\ \text { ANTEL } & \text { El Salvador Chamber of Commerce and Industry } \\ \text { ASI } & \text { National Telecommunications Administration }\end{array}$


Other

\begin{tabular}{|c|c|}
\hline APRA & $\begin{array}{l}\text { Popular American Revolutionary Alliance (fore- } \\
\text { runner of all Latin American Christian Demo- } \\
\text { cratic parties) }\end{array}$ \\
\hline BCIE & Central American Economic Integration Bank \\
\hline BID & Interamerican Development Bank \\
\hline CESPO & Center for Social and Population Studies \\
\hline CIAT & Interamerican Center for Tax Administrators \\
\hline CICAP & $\begin{array}{l}\text { Interamerican Center for the Strengthening of Pub- } \\
\text { lic Administration }\end{array}$ \\
\hline CIET & Interamerican Center for Tax Studies \\
\hline ESAPAC & $\begin{array}{l}\text { Central American Advanced School for Public Admin- } \\
\text { istration }\end{array}$ \\
\hline ICAP & $\begin{array}{l}\text { Central American Institute for Public Administra- } \\
\text { tion }\end{array}$ \\
\hline ODECA & Organization of Central American States \\
\hline OEA & Organization of American States \\
\hline OIT & International Labor Organization \\
\hline ONU & United Nations \\
\hline SIECA & $\begin{array}{l}\text { Permanent Secretary of the General Movement for } \\
\text { Central American Economic Integration }\end{array}$ \\
\hline
\end{tabular}




\section{APPENDIX B}

\section{GINI COEFFICIENTS}

The Gini coefficient (or ratio) is a measure showing how closely an actual distribution approaches absolute equality or inequality. Essentially, it is a measure of concentration. Most often it is used to describe income distribution but may also be used, as shown above, for distribution of land and political power. Gini coefficients are named for their developer, Corrado Gini, an early twentieth-century Italian 1 statistician and economist.

The Gini coefficient as it is known today is based on the Lorenz 2

curve. The Lorenz curve is a simple graphic device plotting cumulated percents of the commodity under discussion against cumulated percents of persons sharing in the distribution of that commodity. Figure 16 below provides an example, using income as the subject.

Absolute equality is indicated by the 45-degree straight line. Curve a indicates a slightly unequal distribution and curve $b$ an even less equal distribution of income. It may readily be seen, for example, that: 1) in the perfectly equal situation, the bottom 50 percent of income recipients receive 50 percent of the total income; 2) in the situation represented by curve a, the bottom 50 percent of recipients receive 33 percent of the total income; and 3) in the situation represented by curve b, the bottom 50 percent of recipients receive only 11 percent of the total income. 


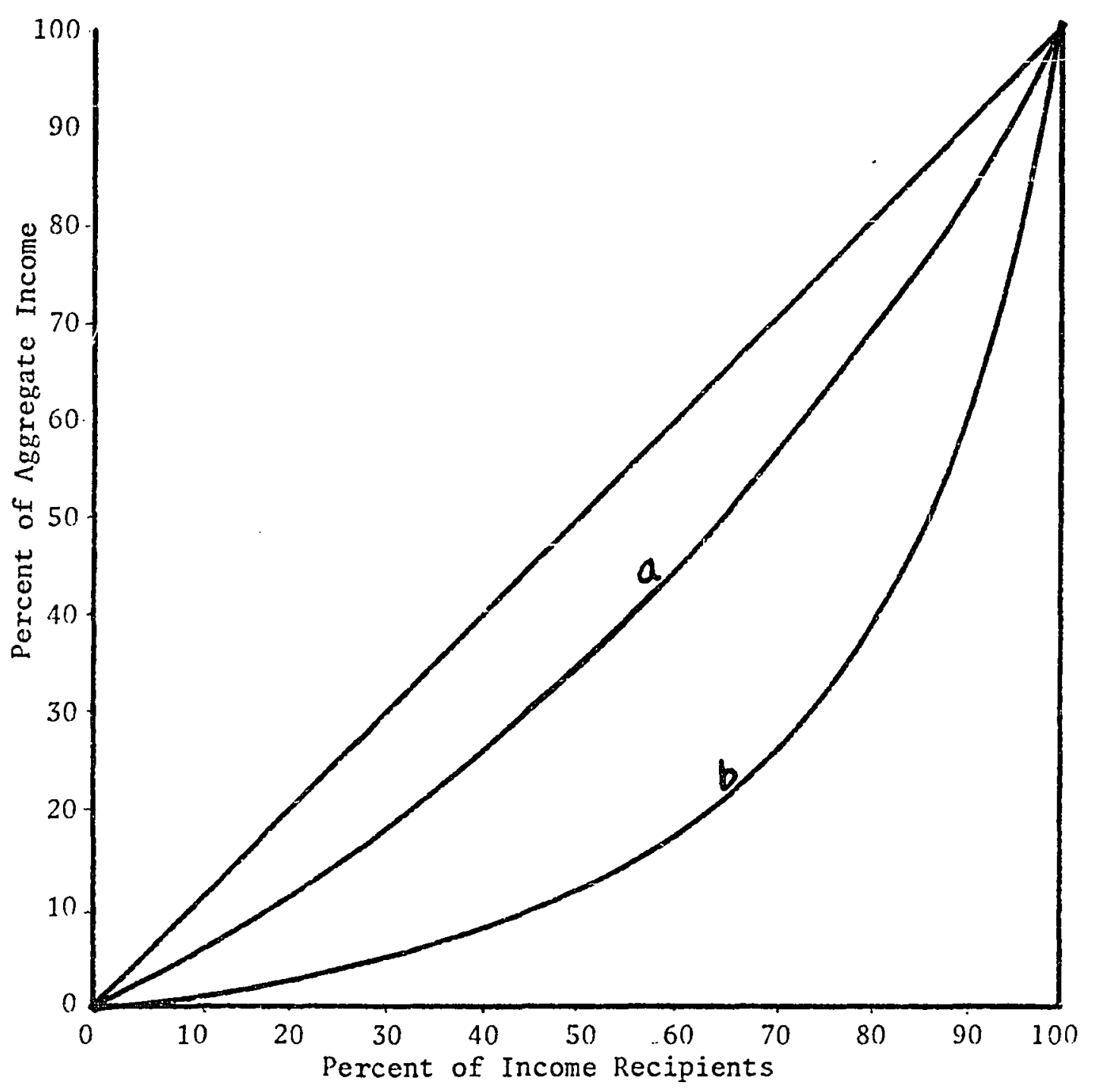

Figure 16. Sample Lorenz curves.

The Lorenz curve, then, provides an easily understood and simply constructed visual picture of a distribution. It may be used to compare several polities, regions or groups and to compare the same po1ity, region or group at different times.

By itself, however, the Lorenz curve suffers from three shortcomings: 1) it requires the drawing of a graph; 2) this graph may become unwieldy if a large number of cases are included; and 3) it 
presents only ordinal, not cardinal comparisons, i.e., one can determine that a commodity is more concentrated in one situation than in another, but not how much more.

In an effort to alleviate these shortcomings and allow more precision in expressing comparative distributions, Gini developed his coefficient. It is, simply, the ratio of the area between the Lorenz curve and the 45-degree line to the total area of the triangle bounded by the $X$ axis, the $Y$ axis, and the 45-degree Iine.

The more unequal and concentrated the distribution, the farther from the 45-degree line will be the Lorenz curve and the greater will be the Gini coefficient. At the extremes, absolute equality of distribution would result in a Gini ratio of zero and absolute concentration in one individual would result in a Gini coeffecient of one.

In our example (Figure 16), the Gini coefficient for the situation represented by Lorenz curve a is obviously less than that for Lorenz curve b. Actual coefficient for a in this example is approxiimately 0.23 and for $b$ it is about 0.58 .

In essence, then, Gini coefficients are simple arithmetic ratios indicating degree of concentration or dispersion of a particular commodity. As dimensionless numbers, Gini coefficients allow for uncomplicated, systematic cardinal comparisons among a variety of groups, polities or regions. Although only one of a number of such meas3 sures, it is the one most widely used by economists and social scientists. 
1. A thorough account may be found in Corrado Gini, "Indici di concentrazione e di dipendenza," Biblioteca dell' Economista, 5a serie, 20 (1922) : 39-40.

2. M.C. Lorenz, "Methods of Measuring the Concentration of Wealth," Publications of the American Statistical Association 9 (1905):209219.

3. For a more detailed discussion of several of these, see Mary Jean Bowman, "A Graphical Analysis of Personal Income Distribution in the United States," American Economic Review 35 (1945):607-628. 
APPENDIX C

ELECTION PROCEDURE IN THE QUOTIENT OR MODIFIED D'HONDT SYSTEM

Both municipal and national elections in Costa Rica are carried out under the quotient or modified d'Hondt system of proportional representation. This system is perhaps best illustrated by a simple model. Assume a municipality with an electorate of 100,000 voters, five parties and ten seats at stake. The quotient for an election is a numerical reckoning of the number of votes necessary to fill one position. In our example there are 100,000 voters and ten seats so the quotient equals $100,000 / 10=10,000$ votes. The quotient naturally varies with each election for each office and is based on the number of votes actually cast. It cannot, therefore, be determined until after the election has been held and the votes counted.

Let us assume further that the election results in our model municipality show the following:

$\begin{array}{lr}\text { Party } & \text { Number of votes } \\ \text { A } & 34,921 \\ \text { B } & 34,636 \\ \text { C } & 5,526 \\ \text { D } & 19,923 \\ \text { E } & 4,994\end{array}$

The first step is to determine how many seats are awarded by full quotient. (In this election we determined a full quotient to be 10,000 votes.) Examination of the results show Pariies $A$ and $B$ to each have three of these quotients and Party $D$ to have one. Seats 
are assigned and residual votes calculated. The situation now appears thus:

$\begin{array}{lll}\text { Party } & \begin{array}{l}\text { Number of seats } \\ \text { by quotient }\end{array} & \begin{array}{l}\text { Residual } \\ \text { votes }\end{array} \\ \text { A } & 3 & 4,921 \\ \text { B } & 3 & 4,636 \\ \text { C } & 0 & 5,526 \\ \text { D } & 1 & 9,923 \\ \text { E } & 0 & 4,994\end{array}$

The next step is to determine semiquotients and assign seats accordingly. As the name indicates, a semiquotient is equal to half a quotient, in this case 5,000 votes. Semiquotient seats are assigned first to any party having a semiquotient and not having a quotient seat. If there is more than one party in this situation, the party with the largest number of residual votes gets the first seat, and so on down the line. Next, seats are assigned in the same manner to parties that do have a seat through quotient but have a number of residual votes greater than the semiquotient. In our example semiquotient seats would go first to Party $C$ and second to Party D. Note again that Party $C$ receives its seat first, even though it has fewer residual votes than Party D. After the allocation of the semiquotient seats, the distribution appears thus:

$\begin{array}{llll}\text { Party } & \begin{array}{l}\text { Quotient } \\ \text { seats }\end{array} & \begin{array}{l}\text { Semiquotient } \\ \text { seats }\end{array} & \begin{array}{l}\text { Residual } \\ \text { votes }\end{array} \\ \text { A } & 3 & 0 & 4,921 \\ \text { B } & 3 & 0 & 4,636 \\ \text { C } & 0 & 1 & 526 \\ \text { D } & 1 & 1 & 4,923 \\ \text { E } & 0 & 0 & 4,994\end{array}$

At this point, there remains one seat and it goes to Party $E$ which now has the largest number of residual votes. The complete distribution 
of seats based on election results appears thus:

$\begin{array}{lllll}\text { Party Votes } & \begin{array}{l}\text { Quotient } \\ \text { seats }\end{array} & \begin{array}{l}\text { Semiquotient } \\ \text { seats }\end{array} & \begin{array}{l}\text { Residual } \\ \text { seats }\end{array} & \begin{array}{l}\text { Total } \% \text { of } \% \text { of } \\ \text { seats votes seats }\end{array}\end{array}$

$\begin{array}{lrrlllrl}\text { A } & 34,921 & 3 & 0 & 0 & 3 & 34.9 & 30 \\ \text { B } & 34,636 & 3 & 0 & 0 & 3 & 34.6 & 30 \\ \text { C } & 5,526 & 0 & 1 & 0 & 1 & 5.5 & 10 \\ \text { D } & 19,923 & 1 & 1 & 0 & 2 & 19.9 & 20 \\ \text { E } & 4,994 & 0 & 0 & 1 & 1 & 5.0 & 10 \\ & & & & 1 & 10 & 100.0 & 100\end{array}$

The actual individuals constituting our model city council are the first three candidates 1isted on Party A's slate, the first three candidates on Party B's slated, the first two on Party D's slate and the single candidates heading the slates of Parties $C$ and $E$.

Two major political considerations are immediately apparent from this example: the importance to the individual candidate of position on the party's slate, and the advantages to very small minority parties of this electoral system. 


\section{APPENDIX D}

\section{SAN SALVADOR ADMINISTRATIVE STRUCTURE}

Actual delivery of services to the citizenry and related fiscal operations are carried out by 12 line departments: Current Accounts, Treasury, Finance, Registration, Urban Development, Community Action, Special Projects, Engineering, Sanitation, Livestock, Markets and Cemeteries. Briefly, the activities of each department are:

1. Current Accounts acts exactly as the name implies. It is concerned with keeping track of addresses, verifying commercial locations, and noticing which firms have gone out of business. This Department also physically examines sites, checking for vacant lots with or without squatters. In short, it keeps the rota of the ratepayers current.

2. The Treasury Department is charged with safekeeping municipal funds and paying bills. It is the city's collection agency. Salvadorean law requires municipal funds collected to be immediately deposited in the Central Reserve Bank of El Salvador.

3. Finance has primary responsibility for developing the budget. It also determines the ability-to-pay of potential ratepayers. General bookkeeping and inventrar of municipal real and moveable property are also carried out here. Finance is, in addition, required to make monthly reports to the council on the state of the municipal fisc. 
4. Registration has one of the most varied sets of activities to perform. It is required to maintain a register, in books of a size and form and with wording specified in the Municipal Act, of births, deaths, marriages, divorces and adoptions. This information must be supplied to the Director General of Statistics and Census. The department also issues certificates of marriage and singleness (never married) and is in charge of all photocopying for the municipality. Perhaps the most important function of Registration in the eyes of the population is the issuing of the cedula, the identity card without which the individual Salvadorean (and Costa Rican) is very much a nonperson, unable to vote, enter business, marry or apply for a passport. The Department is, in addition, the licensing agency for a variety of activities and professions, among them being market stalls, cattle, loudspeakers, man- and animal-powered push carts, firearms, printers, bootblacks and vendors of lottery tickets. Finally, it serves as well as notary public.

5. Urban Development might be regarded most accurately as a control agency. It issues building permits and determines the physical state of existing structures, ordering repair or demolition where appropriate. It reviews building plans both as to siting and to materials to be used in construction, and registers these plans. The Department represents municipal interests at planning hearings and the like before various central government agencies. It also provides some technical assistance to builders and collects statistics on construction activities.

Two related matters ought be mentioned here. One, builders 
need permits from the central government as well as the municipality before beginning any construction. Two, the Department of Urban Development does not engage in land use planning. It may suggest and advise but planning is a function of the national government.

6. The Department of Community Action is charged broadly with the channeling of various municipal and other services to the urban, suburban and rural communities of San Salvador. It is to foster community organizations. Regulation and improvement of the municipal dormitories and juvenile home fall in its purview.

It is also the cultural agency, required to coordinate and plan cultural activities and administer the theater, municipal gallery, and traveling theater. Moreover, in its role as patron of the arts it is "to create in Salvadoreans artistic and cultural capabilities through the media of theater, dance, painting, chorus, ceramics, music, etc."

A wide variety of extension-type services are also mandated. For the farmer, the usual sorts of agricultural extension aid and information are to be supplied. Housewives are to be taught nutrition, budgeting, child care and the general range of skills usually labeled home economics. Finally, the agency is to serve, in U.S. terms, as a giant municipal 4-H club for the youth of San Salvador.

7. Special Projects is a very small department, an offshoot of Engineering. Because of its nature, no formal description of its activities is listed. At the time of the fieldwork in San Salvador it appeared to exist only on paper.

8. Engineering carries out a variety of functions, some of which would most probably be assigned to a Parks agency in most North 
American municipalities. Among these are tree planting, maintenance of public parks, lawns and gardens, and removal of fallen trees and other similar nuisances.

Other activities include topographic surveys, plan approval for drainage works and subsurface construction in general and the usual maintenance and repair of streets, bridges, sidewalks and culverts.

9. Sanitation is charged with garbage collection and disposal, construction of public latrines, and cleaning of streets and sewers. It also has a number of responsibilities related to vermin control including fumigation and vector control and the municipality's role in the national anti-rabies campaign.

10. Livestock is required to issue permits to those wishing to deai in animals or carcasses within the city limits and to license and inspect livestock handlers. It is responsible for checking brands, verifying ownership and keeping records of all transactions. One unit provides both ante- and post-mortem veterinary services. San Salvador also operates, under this Department, a municipal slaughterhouse.

11. Markets is a large Department but one with a relatively simple and straightforward mandate. It assigns (but does not issue licenses for) stalls and floor space, maintains order, discipline and decorum in the markets, carries out cleaning and physical maintenance; and most important, collects the fees from the vendors.

12. Cemeteries is responsible for carrying out all burials and exhunations within the municipality, and for the usual graveyard maintenance. The Department keeps track of location and occupance of 
plots, crypts, niches and vaults, and collects the appropriate fees. In a radical departure from usual North American practice, it is this agency that issues death certificates.

Again, the above description of the administrative structure of San Salvador is cursory. But it does provide a general picture of the organization, and a take-off point for comparison with the structure and practices in San José. 


\section{APPENDIX E}

\section{SAN JOSE ADMINISTRATIVE STRUCTURE}

The remaining municipal activities are classified into seven functional categories: General Administration, Municipal Health, Education and Culture, Economic and Social Services, Maintenance, New Construction and Urban Development. Briefly, the components of each of these categories follow.

1. General Administration includes most of the support and financial services. Among the latter are budget, accounting, treasury, property assessment and rate collection. Debt management and handling of subventions from the central government are also included here. Support services include personnel, purchasing, supplies, and stores. In addition, janitors, watchmen and guards for municipal facilities are provided in this activity.

2. Municipal Health provides a wide range of services. Sweeping of streets and public squares and care of wells and other water supplies are included. Collection of residential and commercial solid waste and its treatment at a site outside the city operated jointly by San José and neighboring municipalities is another function. Finally, cemetery maintenance, gravedigging, and the like are the responsibility of this function.

3. Education and Culture differs somewhat from other activities in that its main function is the provision of money rather than 
services. Some of this money goe: to local school boards, some in the form of scholarships to needy aind worthy students. Funds are also provided here to ad hoc groups in charge of celebrations for national and municipal holidays. Employees from various agencies are pressed into service temporarily for these festivities. The only service qua service provided here is the ope zion of the Municipai Children's Library.

4. Economic and Social Services is more economic than social. Its chief function is operating the city's four markets and the bus station attached to one of these. It is the only operation to 'show a profit' as it includes the parking meters. Streetlighting is included here. However, since the actual lighting service is provided by a private enterprise, Compañía Nacional de Fuerza y Luz, S.A., activities are limited to contract negotiation and ensuring of compliance.

5. Maintenance performs three main functions. First is the repair of streets and roads and the cleaning of storm sewers. Second is general maintenance, but not janitorial service, to municipal buildings. Third is keeping in good order the various public parks, playgrounds, forests, gardens and other open spaces of the municipality.

6. New Construction deals primarily with roads. While new buildings and major repairs and additions are handled here, none were ongoing or planned at the time of the field work in San José. All phases of new construction are involved--initial planning and engineering, land assembly, allocation of costs (e.g., for heavy 
equipment used on more than one job) to various projects and the actual physical construction. The operation of the municipal garage is also included.

7. Planning and Control of Urban Development is the formal title of the last function but it is concerned more with control than with planning. Two major activities are carried out: examination and approval of plans as to both technical specifications and conformity to the municipal general plan, and on-site inspection of new construction. 


\section{APPENDIX F}

NOTE ON DATA SOURCES

At various places in the body of the paper, as appropriate, comments are made on the sources of numerical data. In this Appendix a general description of data sources, data handling and difficulties with the data is presented.

In Costa Rica five major data sources were used. These were the Central Bank, the Comptroller General, the Office of Census and Statistics, the National Planning office and the Municipality of San José. References to specific figures used are indicated in the text. The Central Bank provided most of the data on the national economy, while figures on government revenues and expenditures came from the Comptroller General. Population measurements and estimates came from the Office of Census and Statistics. Planning Office data applied to specific activities; these data did not fit into any particular classification. The Municipality supplied much of the data on its own financial activities. Some of these data, however, were available only from the Comptroller General.

In El Salvador, four major data sources were consulted. These were CONAPLAN, the Central Reserve Bank, the Office of Census and Statistics, and the Municipality of San Salvador. CONAPLAN provided broad data on the national economy and on government revenues and expenditures. More specific data, such as the details of a particular 
bond sale, were obtained from the Central Reserve Bank. Figures on population and some on housing were supplied by the Office oi Census and Statistics. The Municipality made data on its own activities available to the best of its limited ability. In both El Salvador and Costa Rica, of course, most of the housing data came from the involved agencies, IVU, INVU añd FÜNDASAL.

Comparative data on the two countries were presented by a number of organizations, among them the Inter-American Development Bank, U.S. Agency for International Development, Organization of Central American State, and various divisions of the United Nations. The single most valuable source of comparative data was the oft-cited UNICEF publication Las Sociedades Centroamericanas Actuales.

In virtually all cases, financial data as obtained were expressed in the national currencies of the respective countries. For purposes of comparison, these were converted by the writer into Central American pesos. The Central American peso is an artifical currency, like the Eurodollar, widely used in international bookkeaping among members of the Central American Common Market. This peso is pegged at par with the U.S. dollar. Conversions were calculated at the rate of $\$ 1.00 \mathrm{C.A} .=\$ 6.62$ (Costa $\mathrm{Rican})=\$ 2.50$ (Salvadorean). Use of the Central American peso eliminated a great deal of confusion due to the designation of the colon as the national currency unit in both countries.

CONAPLAN provided economic data in both current and fixed (1962) colones for San Salvador. The writer calculated the necessary adjustments to Costa Rican current figures to assign them constant (1962) 
equivalents.

Except as otherwise noted in the text, percentages, percentage changes, per capita amounts, ratios and similar numerical expressions were calculated by the writer from the raw data. Parenthetically, it should be mentioned that all Spanish-to-English translations and interpretations in the paper are the work of the writer alone.

Data gathering for this paper was a far more arduous and timeconsuming task in Costa Rica than in E1 Salvador. In the latter country CONAPLAN's quarterly Indicadores Económicos y Sociales provides a wealth of information on El Salvador's demography, national accounts, economic activity, public finânce, money and banking, and human resources. Not only is current data supplied but each issue contains data for at least the five most recent years. Comparisons over time are thus quite straightforward. In addition, the Central Reserve Bank. publishes a monthly review covering all important public and private sector financial transaction, changes in the money supply and similar matters. All this information is readily available.

Securing such data in Costa Rica, however, involves poring over the Comptroller's massive annual report for each year and extracting bits and pieces of sought-after data wherever they may be found. With the exception of one study by the Central Bank, data for more than one year are not compiled in any single location. Much of the needed data, moreover, is simply not published. Obtaining it, therefore, means days of searching records in the Comptroller's office and hand copying whatever is needed.

In fairness, though, it should be noted that in two cases data 
were more readily available in Costa Rica than in El Salvador. INVU provided, generally, a more complete set of data than did IVU; San José Municipality was able to present a far more thorough picture of its financial situation than was its Salvadorean counterpart.

A number of difficulties arose in obtaining and comparing data. Several of these have been referred to above as they cropped up in the text. Nonetheless it is appropriate to assemble them here. One of the major problems was that in neither country is the municipality the unit for which statistics are gathered. It was necessary, then, to use proxies, i.e., the urban area of San José Province and Metropolitan San Salvador. Another problem was that the format in which data were assembled was not necessarily the format most convenient in the preparation of this paper. A related difficulty occurred when formats changed from year to year as, for example, when categories were expanded or collapsed into one another.

Occasionally, different sources provided different data on the same phenomenon. When this occurred it was necessary to seek some external verification, some reason for choosing one data set over another. A particular subgroup of this problem was found when international agencies gave different figures than the national government for phenomena within its boundaries.

Yet another difficulty arose from Costa Rica holding its national census in 1973 anci El Salvador in 1971. In the one case the figures were more recent but still preliminary; in the other, older but revised.

Finally, there is the possibility of suppression or modification 
of particular data that reflect adversely on government policy. The one specific case where this was suspected was identified in the text. The ultimate questions arising from all these considerations are, of course: How much faith can be placed in the data for the two poliiies?; and, How comparable are these data? We admit that there are enough uncertainties about the data to preclude sophisticated statistical analysis. But then, we question the appropriateness of such analysis to this particular paper, holding with Wassily Leontief that uncritical enthusiasm for mathematical formulation tends often to concel the ephemeral substantive content of the argument behind the formidable front of algebraic signs. 2

The usual caveats in using our data have been invoked throughout the paper. Special care has been taken when comparing changes between censuses to point out to the reader the different dates involved. More information is provided in this fashion than is lost or distorted through lack of perfect coincidence. In short, while care and caution, even suspicion, must be used in assembling, analyzing, and comparing the data, we have to do as much with them as we can because, after all, they are all the data that exist.

\section{APPENDIX F NOTES}

1. For a detailed discussion of this point see Thomas I, Dickson, "The Contribution of the Inter-American Development Bank to the Latin American Statistics Muddle," Inter-American Economic Affairs 28 (1974): 79-85.

2. Wassily Leontief, "Theoretical Assumptions and Nonobserved Facts," American Economic Review 61 (1971):1-2. 